$$
\text { UNIVERSIDADE DE SÃO PAULO }
$$

FACULDADE DE FILOSOFIA, LETRAS E CIÊNCIAS HUMANAS DEPARTAMENTO DE GEOGRAFIA

PROGRAMA DE PÓS-GRADUAÇÃO EM GEOGRAFIA HUMANA

A PRODUÇÃO DO ESPAÇO URBANO DE BOA VISTA - RORAIMA

Antonio Tolrino de Rezende Veras 


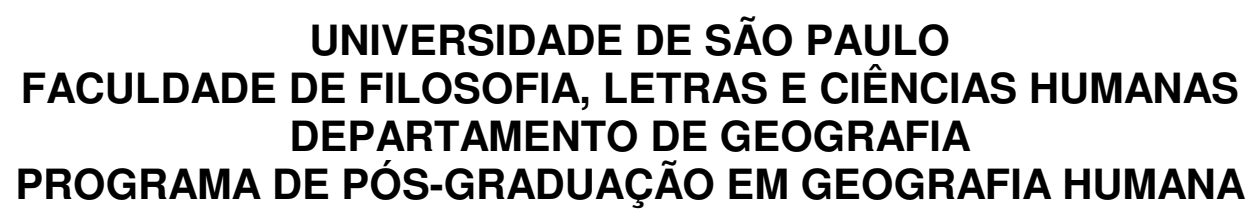

A PRODUÇÃO DO ESPAÇO URBANO DE BOA VISTA - RORAIMA

Antonio Tolrino de Rezende Veras

Tese apresentada ao Programa de Pós-Grduação em Geografia Humana da Faculdade de Filosofia, Letras e Ciências Humanas da Universidade de São Paulo, para obtenção do titulo de doutor em Geografia Humana. 
AUTORIZO A REPRODUÇÃO E DIVULGAÇÃO TOTAL OU PARCIAL DESTE TRABALHO, POR QUALQUER MEIO CONVENCIONAL OU ELETRÔNICO, PARA FINS DE ESTUDO E PESQUISA, DESDE QUE CITADA A FONTE.

ASSINATURA:

E-MAIL: tolrino@bol.com.br

Serviço de Biblioteca e Documentação da Faculdade de Filosofia, Letras e Ciências Humanas da Universidade de São Paulo

\section{Veras, Antonio Tolrino de Rezende}

A produção do espaço urbano e Boa Vista-Roraima; orientador Francisco Capuano Scarlato.--São Paulo, 2009.

Tese (Doutorado - Programa de Pós-Graduação em Geografia Humana. Área de concentração: Geografia Humana) - Departamento de Geografia da Faculdade de Filosofia, Letras e Ciências Humanas da Universidade de São Paulo.

1. Cidades da Amazônia (Geografia; Aspectos urbanísticos), 2. Produção do espaço (Boa VistaRoraima), 3.Urbanização (Boa Vista-Roraima), 4. Fronteira. 
Autor: Antonio Tolrino de Rezende Veras

Título da Tese: A produção do espaço urbano de Boa Vista - Roraima.

Local/Data da Defesa:

\section{Banca Examinadora}

Prof. Dr.

Instituição:

Julgamento:

Assinatura:

Prof. Dr.

Instituição:

Julgamento:

Assinatura:

Prof. Dr.

Instituição:

Julgamento:

Assinatura:

Prof. Dr.

Instituição:

Julgamento:

Assinatura:

Prof. Dr.

Instituição:

Julgamento:

Assinatura: 


\section{DEDICATÓRIA}

Dedico esse trabalho a minha esposa Sandra Veras e filhos Rafael e Laura - desculpe a ausência em determinados momentos, e a meu pai João Veras, que partiu para outro plano espiritual. 


\section{IN MEMORIAN}

Uma saudade.

Pai, querido e amado, que me deu um exemplo de vida.

Você sabe, aí do céu, que tem muito de você nessa caminhada. 


\section{AGRADECIMENTOS}

Agradeço a fé que tenho em DEUS, que me cerca de força e objetivos.

Em outra escala, agradeço a minha mãe Raimunda Veras e aos meus queridos irmãos, Edilberto, France, Socorro, José, Vera, João e Solânia, que contribuíram e compartilharam, em cada momento de minha trajetória.

Da mesma forma,agradeço ao meu orientador, Professor Francisco Capuano Scarlato, pela orientação, pela confiança, pela paciência, pela compreensão das dificuldades e pela relação fraternal de companheirismo ao longo deste trabalho.

Ao Professor Mário de Biasi e a Professora Amália Inês pelas intensas contribuições no exame de Qualificação.

Aos professores Jaime de Agostinho, Stélio Soares Tavares Junior e Paulo Rogério de Freitas Silva que me apoiaram no desenvolvimento da pesquisa.

Ao amigo João Theófilo R. Pereira que sempre esteve presente nas pesquisas de campo.

Aos meus tios Maria e Antonio que me acolheram com amor e carinho em sua residência durante o período de elaboração da tese.

A Universidade Federal de Roraima em especial aos meus colegas do Instituto de Geociências que deram apoio nesta trajetória.

A Universidade de São Paulo, que através do Programa de Pós-Graduação em Geografia Humana da Faculdade de Filosofia, Letras e Ciências Humanas, que disponibilizou tantas formas especiais de pensar o urbano.

As instituições, órgãos, entre outros, que contribuíram e que eu não saberia a quem agradecer em primeiro lugar, dessa forma, meu muito obrigado a todos. 


\section{RESUMO}

VERAS, Antonio Tolrino de Rezende. A produção do espaço urbano de Boa Vista-Roraima - Brasil. 2009. Tese de Doutorado - Faculdade de Filosofia, Letras e Ciências Humana, Departamento de Geografia, Universidade de São Paulo, São Paulo.

O que se propõe nesse estudo é mostrar como se deu o processo de produção do espaço urbano de Boa Vista, capital do estado de Roraima, visto como produto histórico e social em três momentos de sua formação sócioespacial: inicialmente, quando estava sob a jurisdição do estado do Amazonas, entre 1890 e 1943; num segundo momento, quando da criação do Território Federal do Rio Branco, em 1943 e a implantação do plano urbanístico da cidade em 1944, finalmente, a partir da transformação do Território Federal de Roraima em Estado, em 1988. As premissas desse estudo serão definidas a partir da leitura dos sistemas de objetos e de ações incorporadas pelos agentes promotores do espaço urbano, como o gestor público federal, estadual e municipal, especulares fundiários e instituições privadas entre outros, dentro de uma perspectiva espaço-temporal. Neste quadro complexo é que se pretende abrir as discussões sobre o espaço intra-urbano da capital roraimense, que nos relatos, documentos e estudos dão conta da inserção de sucessivas modernidades que retratam a abrangência de sua expressão local como centro polarizador de equipamentos e serviços urbanos no Estado.Nesta perspectiva, entendemos que a produção do espaço urbanos de Boa Vista aumentou a diferenciação do espaço, propiciando a formação de territórios diferenciados.

Palavras-Chave: Cidades da Amazônia, produção do espaço, primazia urbana, fronteira. 


\begin{abstract}
VERAS, Antonio Tolrino de Rezende. The production of the urban space of Boa Vista-Roraima - Brazil. 2009. Doctor's Thesis - College of Philosophy, Letters and Human Sciences, Departament of Geography, University of São Paulo, São Paulo, Brazil.

What is proposed in this work is to show the process of the production of urban space of Boa Vista, capital of the state of Roraima, seen as a historic and social product in three moments of its socio-spatial formation: initially, when it was under the jurisdiction of the state of Amazonas, between 1890 and 1943; in a second moment, when the Federal Territory of Rio Branco was created, in 1943 - when the urban plan of the city was made, in 1944, and, finally, after the transformation of the Federal Territory of Roraima into a State, in 1988. The premises of this work will be defined from the reading of the systems of objects and actions embodied by the agents who promoted the urban space, such as the federal, state and municipal, land speculators and private institutions, among others, within a space-temporal perspective. Within this complex frame one intends to open discussions about the intra-urban space of the capital of Roraima, which, in accounts, documents and studies narrate the insertion of successive modernities that depict the amplitude of its local expression as a polarizing center of urban goods and services in the State. In this perspective, we understand that the production of the urban space of Boa Vista increased the differentiation of space, favoring, thus, the formation of differentiated territories.
\end{abstract}

Key-Words: Cities of the Amazon, Production of Space, Primacy urban, Border. 


\section{SUMÁRIO}

INTRODUÇÃO

Objetivos

Hipótese

Revisão da Literatura

Técnicas de pesquisas

Estrutura dos capítulos da tese

CAPÍTULO I - PROCESSO DE OCUPAÇÃO DO VALE DO RIO BRANCO

1.1 Processos político e produção do vale do rio Branco 35

1.2 Vila de Boa Vista do Rio Branco - uma questão em discussão .......................... 39

1.2.1. Caminhos para sua formação sócioespacial ........................................... 41

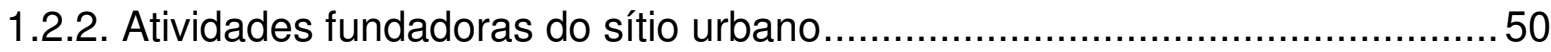

1.2.3. Dinâmica e estruturação político - administrativas: fazenda - freguesia

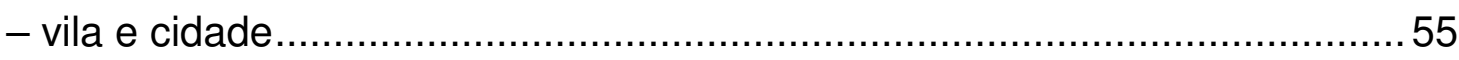

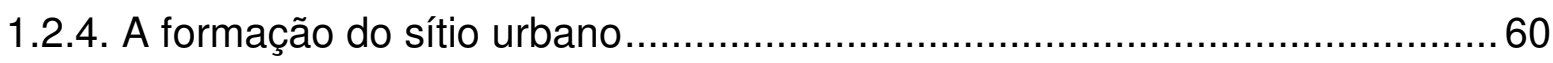

CAPÍTULO II - REDEFININDO A FORMAÇÃO SÓCIOESPACIAL DE BOA VISTA A PARTIR DA CRIAÇÃO DO TERRITÓRIO FEDERAL DO RIO BRANCO NO ANO DE 1943 E DA IMPLANTAÇÃO DO PLANO URBANÍSTICO EM 1944

2.1 A criação do Território Federal do Rio Branco e sua importância na dinâmica de produção do espaço urbano de Boa Vista ...........................................78

2.1.1Realidade sócioespacial do território e sua relação com Boa Vista.................88

2.2 A implantação do plano urbanístico .............................................................95

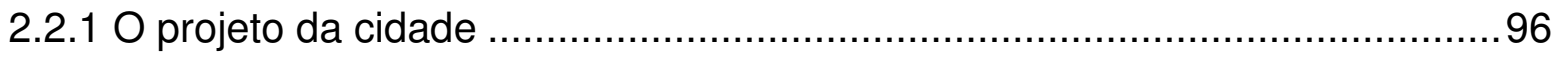

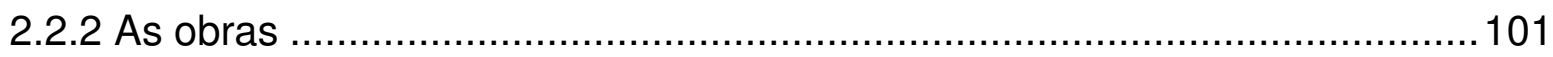

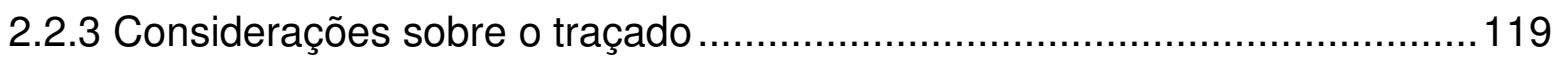


3.1 Localização do município de Boa Vista: Destaque para a área de estudo mancha urbana

3.2 Território Federal do Rio Branco (Roraima) face às ações políticoadministrativas de desenvolvimento na Amazônia e sua relação com Boa Vista

3.2.1 A cidade de Boa Vista - dinâmica de produção 140

3.3 Dinâmica intra-urbana de Boa Vista a partir da implantação do plano urbanístico

3.4 A criação do Estado de Roraima e sua importância na dinâmica urbana de Boa Vista. 162

3.5 Plano Diretor Estratégico de Boa Vista.... 183

3.5.1 A questão fundiária urbana $x$ planejamento urbano 195

3.6 Rugosidades e tendências atuais na dinâmica urbana de Boa Vista 197

CONSIDERAÇÕES FINAIS 


\section{LISTA DE FIGURAS}

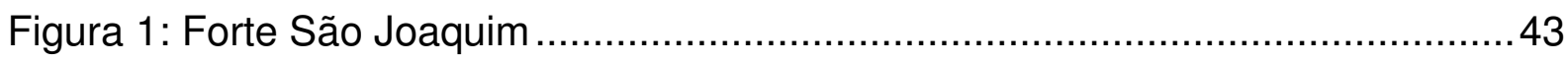

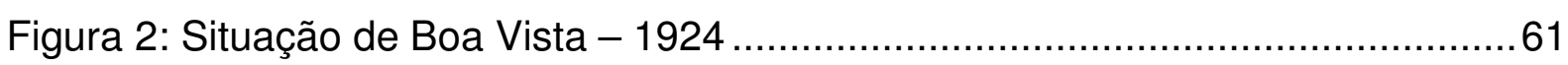

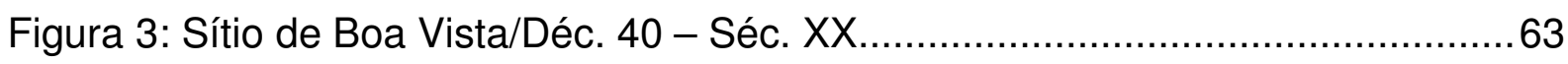

Figura 4: Porto de Boa Vista do Rio Branco/Déc. 20 - Séc. XX...............................64

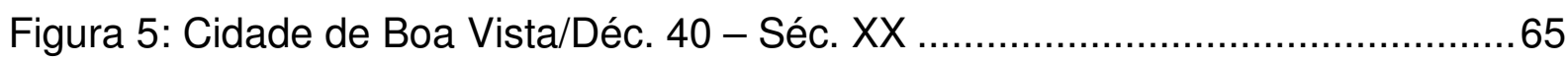

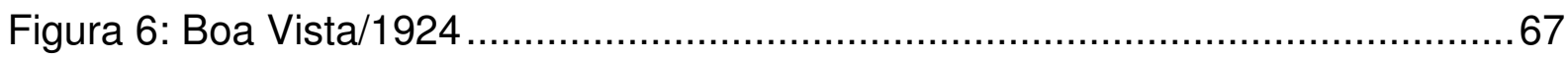

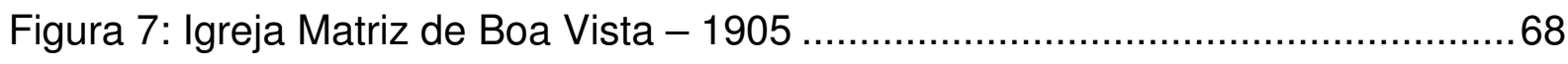

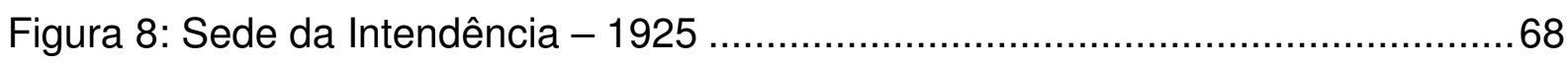

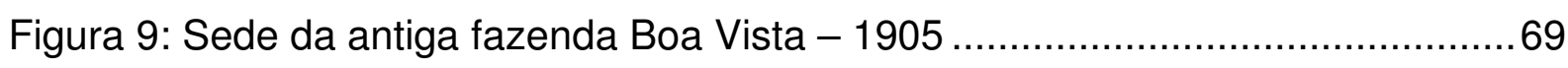

Figura 10: Meio de transporte/Déc. 20 - Séc. XX ……...................................... 70

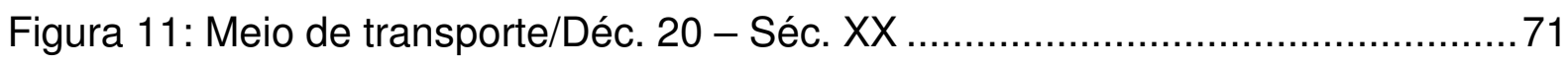

Figura 12: Residências antigas de Boa Vista/Déc. 50 - Séc. XX (Jaime Brasil) .......75

Figura 13: Tipo de residências em Boa Vista/Déc. 20 - Séc. XX............................77

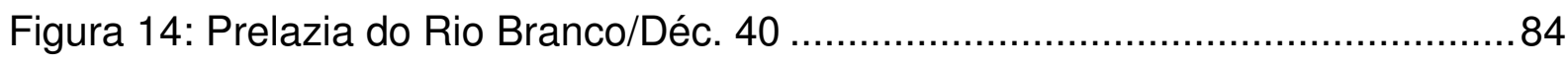

Figura 15: Residências de taipa em Boa Vista/Déc. 40 - Séc. XX...........................90

Figura 16: Maquete do plano urbanístico de Boa Vista/1944 (traçado urbano: radial - concêntrico) ......................................................................... 95

Figura 17: Assinatura do contrato para execução do plano urbanístico da

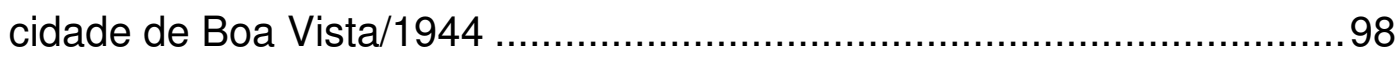

Figura 18: Primeiro levantamento topográfico da cidade de Boa Vista/Déc. 40 -

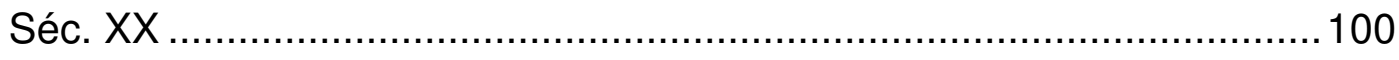

Figura 19: Obras do primeiro conjunto habitacional/Déc. 40 - Séc. XX .................. 102

Figura 20: Colégio Lobo D’almada/Déc. 50 - Século XX ..................................... 103

Figura 21: Riobras Industrial Ltda/Déc. 40 - Século XX ......................................... 104

Figura 22: Os pioneiros na construção de Boa Vista/Déc. 40 - Séc. XX ................. 105

Figura 23: Avenida Floriano Peixoto/Déc. 40 - Séc. XX ..................................... 107

Figura 24: Avenida Floriano Peixoto/Déc. 40 - Séc. XX ...................................... 107

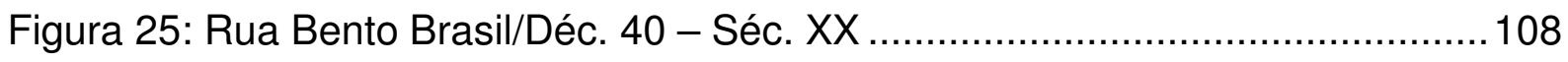

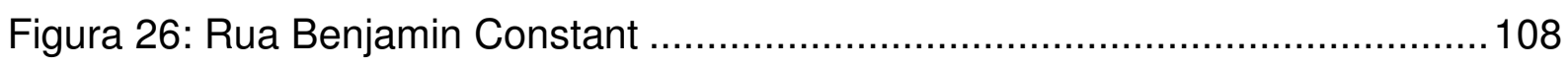

Figura 27: Avenida Jaime Brasil/Déc. 40 - Séc. XX ………................................ 109

Figura 28: Avenida Jaime Brasil/Déc. 40 - Séc. XX............................................... 109

Figura 29: Rua 5 de Setembro/Déc. 40 - Séc. XX ............................................110 


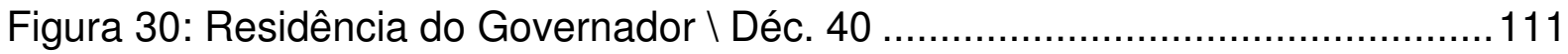

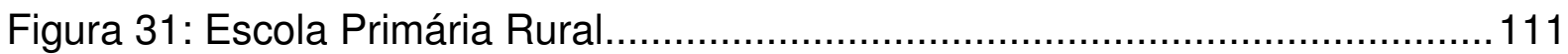

Figura 32: Escola Primária Rural em Mecejana/Déc. 40 ……............................112

Figura 33: Matadouro publico de Boa Vista/Déc. 40 .........................................112

Figura 34: Praça Capitão Clovis/Déc. 40 …....................................................113

Figura 35: Construção do atual Hotel Aipana Plaza/Déc. 40..................................113

Figura 36: Hotel Aipana Plaza em novembro de 1950 .....................................114

Figura 37: Praça do centro Cívico - Palácio do Governo/Déc. 40 - Séc. XX .........114

Figura 38: Limite do traçado radial concêntrico/1945 ............................................115

Figura 39: Diagrama de Howard / Planejamento............................................... 121

Figura 40: Diagrama de Howard/Distrito e Centro...............................................121

Figura 41: Área central de Boa Vista / Déc. 70 - Séc. XX ..................................123

Figura 42: Rotatória do cruzamento da Avenida Ville Roy com Santos

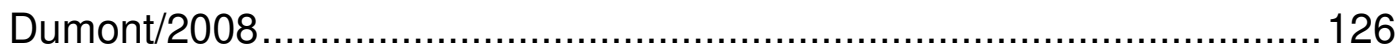

Figura 43: Boa Vista: modelo radial concêntrico / Séc. XXI ................................. 127

Figura 44: Vista aérea da Praça do centro Cívico de Boa Vista / 2008 ................... 130

Figura 45: Vista aérea/ Versalhes - Paris ........................................................ 130

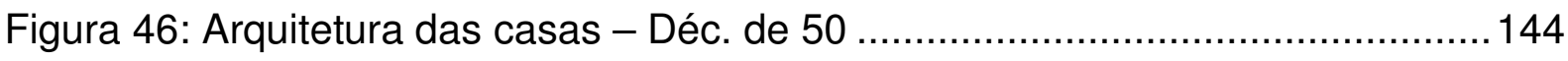

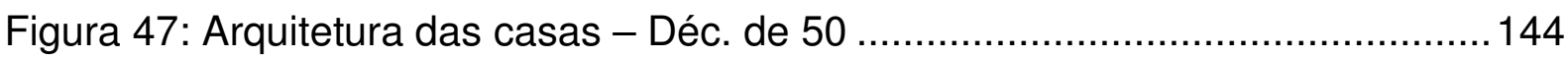

Figura 48: Olaria localizada no bairro Rói-couro/Déc. 50 ....................................146

Figura 49: Avenida Jaime Brasil/Déc. 50 ...................................................146

Figura 50: Inicio das obras de implantação do Complexo Poliesportivo Ayrton

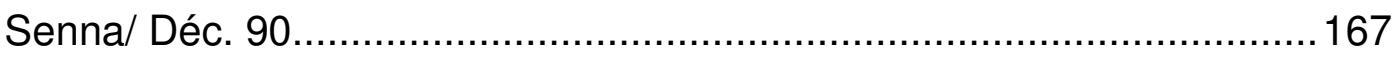

Figura 51: Inicio das obras de implantação do Complexo Poliesportivo Ayrton

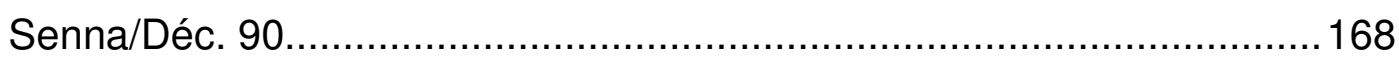

Figura 52: Complexo Poliesportivo Ayrton Senna/2007 …...................................168

Figura 53: Iluminação do Complexo Poliesportivo Ayrton Sennal2007 ...................171

Figura 54: Abrigo de Passageiros/Déc. 90 …………....................................... 172

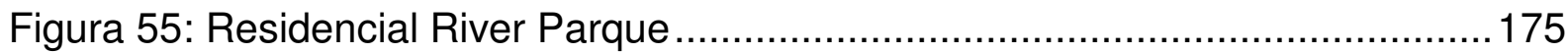

Figura 56: Conjunto do Servidor \Bairro Caranã - Zona Norte............................ 175

Figura 57: Terminal de Integração do Caimbé/João Firmino Netol2006 ..................177

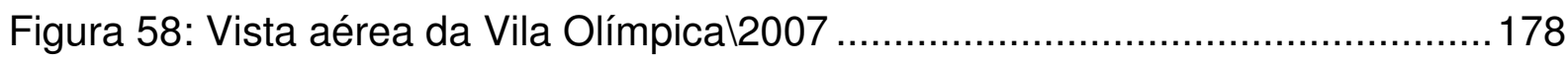

Figura 59: Vista aérea do Parque Germano Augusto Sampaio ............................178

Figura 60: Vista aérea da Orla Taumanan/2007 .............................................180 


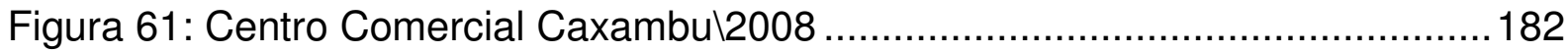

Figura 62: Zona Oeste de Boa Vista sentido ao Município de Alto Alegre .............. 186

Figura 63: Ocupação irregular - Monte das Oliveiras Zona Norte ........................ 187

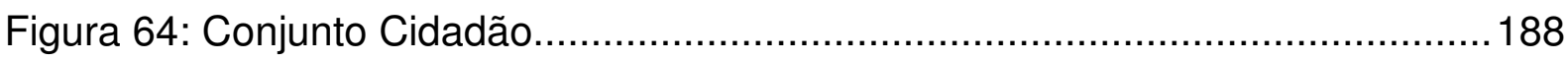

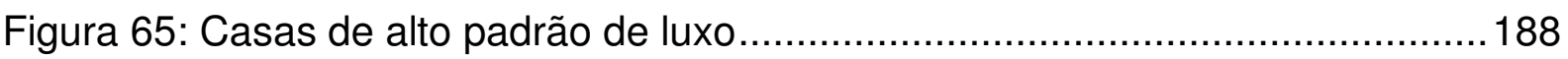

Figura 66: Lançamento de esgoto "in natura" no rio Branco ................................... 190

Figura 67: Vista aérea da margem direita do rio Branco .......................................197

Figura 68: Zona Leste e Oeste da cidade de Boa Vista ......................................201

Figura 69: Subcentro comercial - Avenida Ataíde Teive ......................................202

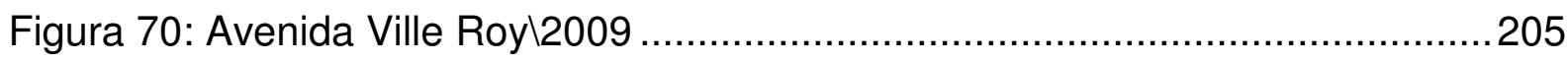

Figura 71: Av. Jaime Brasil (área comercial) - 2009.............................................206

Figura 72: Faculdade Cathedral|Bairro Paraviana ...........................................207

Figura 73: Edifício residencial Varandas do Rio Branco ......................................208

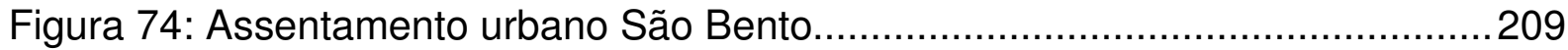

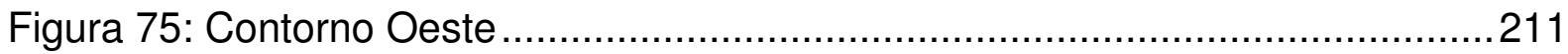




\section{LISTA DE MAPAS}

Mapa 1: Estado de Roraima \Hidrografia-2008: Localização do rio Branco ..............42

Mapa 2: Localização do Forte São Joaquim, fazendas e colônias............................52

Mapa 3: Planta da Vila de Boa Vista do Rio Branco/1924 ....................................57

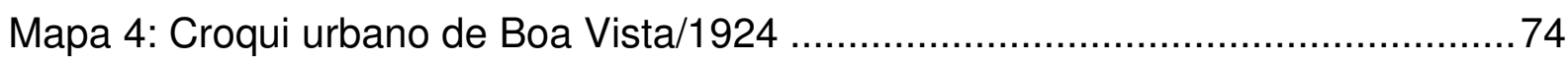

Mapa 5: Divisão de Roraima em municípios a partir de 1943 .................................... 82

Mapa 6: Posição estratégica e geopolítica de Boa Vista........................................86

Mapa 7: Radiais do traçado urbano que partem do centro/2008 .......................... 124

Mapa 8: Localização do município de Boa Vista; Destaque para a área de estudo - mancha urbana.................................................................... 133

Mapa 9: Posição estratégica e geopolítica de Boa Vista no Projeto Calha Norte ... 139

Mapa 10: Zoneamento de uso e ocupação do solo urbano de Boa Vista/1977 ...... 152

Mapa 11: Mapa de localização das zonas urbanas/1980..................................... 156

Mapa 12: Sistemas de esgoto sanitário de Boa Vista/1980 .................................158

Mapa 13: Evolução do espaço urbano de Boa Vista/Déc. 20 a 80.......................... 160

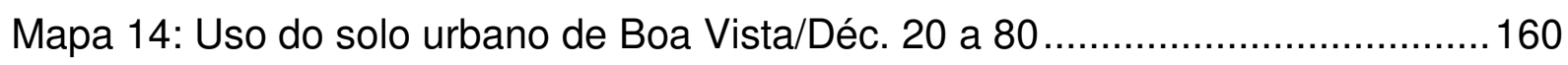

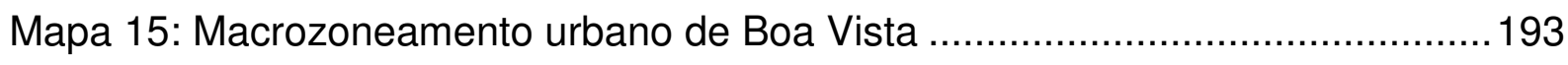

Mapa 16: Dinâmica da produção do espaço urbano de Boa Vista \Área inicial

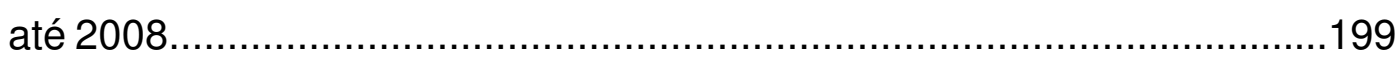

Mapa 17: Dispersão comercial de Boa Vista..................................................203 


\section{LISTA DE QUADROS}

Quadro 1: Periodização da dinâmica de produção sócioespaçial de Boa Vista........49

Quadro 2: Orçamento do plano urbanístico de Boa Vista/1944 …...........................97

Quadro 3: Área pavimentada em paralelepípedos por bairro\ Déc. De $90 \ldots \ldots \ldots \ldots . . . .166$

Quadro 4: Área pavimentada em asfalto por bairrolDéc. De 90............................... 167

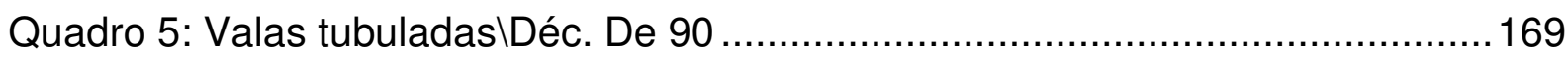

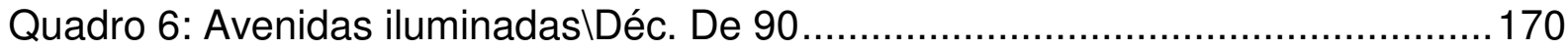

Quadro 7: Praças com iluminação|Déc. De 90...................................................170

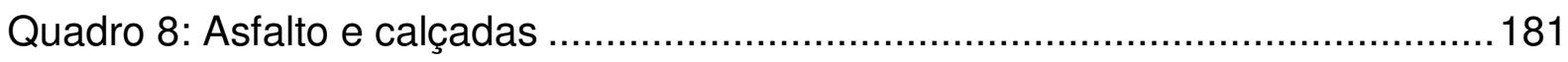

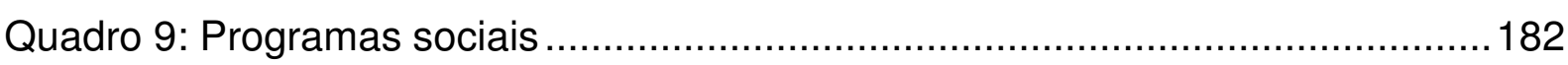

\section{LISTA DE TABELAS}

Tabela 1: Evolução da população do município de Boa Vista/1950-1980 ...............155

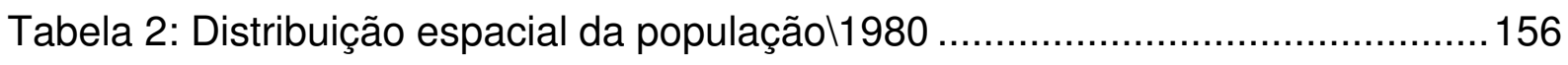

Tabela 3: Distribuição espacial da população por bairrol1980 ..............................157

\section{LISTA DE ORGANOGRAMAS}

Organograma 1: Periodização da dinâmica político-adminsitrativa de Boa Vista......58 


\section{INTRODUÇÃO}

O nosso interesse pelo tema, a produção do espaço urbano de Boa Vista Roraima - surgiu em razão de querermos contribuir na compreensão do processo de produção do espaço urbano das cidades da Amazônia setentrional,em particular da cidade de Boa Vista, que possui pouco documento científico sobre a questão urbana. O que se tem a esse respeito limita-se a uma vaga literatura, representada em obras que prestam apenas algumas informações gerais e incipientes para compreensão da dinâmica local.

A formação sócioespacial de Boa Vista e os problemas na morfologia urbana que deles decorrem envolvem uma conjuntura de questões econômicas, sociais, política e institucionais, sendo estas, ademais,enfocadas sob os mais diversos ângulos e vertentes ideológicas. A noção dominante é a de que a estrutura do espaço intra-urbano resulta da ocupação desordenada do seu solo, resultando em desequilíbrios ou disfunções urbanas.

$O$ atual estado de Roraima tem sua gênese na antiga fazenda Boa Vista, implantada em 1830 e transformada em município em 1890 como ação estratégica para a consolidação da geopolítica amazônica na fronteira setentrional do país.

Já na década de 30 do século XX, ainda sob a jurisdição do Estado do Amazonas, Vieira (2003, p. 62) diz que essa região viu-se excluída do cenário nacional, uma vez que os esforços de industrialização, iniciados nos anos 30 , concentraram-se no Sul e sudeste do país. Consequentemente, esse processo não chegava nesta região.

Até o ano de 1940, os habitantes do Estado concentravam-se no meio rural. A transformação da área em Território Federal do Rio Branco, em 1943, gerou uma mobilidade crescente de moradores vindos do interior e um fluxo migratório de outras regiões do país para a capital Boa Vista. Tal mobilidade, muitas vezes auxiliada pelos governadores nomeados à época, tinha como objetivo dotar a capital do território de uma demanda populacional crescente e criar um centro urbano administrativo.

Em 1944, a cidade estava sendo urbanizada pelo então governador do território, Capitão Êne Garcez dos Reis, com base no plano geral traçado pela firma Darcy A. Derenusson, dentro de um processo de localização em que a proximidade torna-se fator preponderante. Inúmeras atividades, principalmente as de comércio e 
serviços, conformam os centros urbanos - lugares privilegiados de trabalho, do consumo e das trocas, a partir dos quais se estrutura o ir e vir citadino,embora tendente à centralização e sem capacidade suficiente de suprir a demanda da cidade.

Nessa relação dinâmica entre as formas de organização, que se inicia na década de 40 do século $X X$ e se prolonga até os dias atuais, a cidade apresenta distorções na forma de uso do seu espaço urbano, ou seja, o seu setor Leste foi definido como área nobre; enquanto que o setor Oeste, o periférico, é marcado pela privatização dos benefícios da urbanização e pela marginalização das populações mais pobres, historicamente excluídas dos bens e serviços produzidos pela sociedade.

Os problemas gerados pelas bruscas mudanças na distribuição populacional são enormes, diversos e em escalas consideráveis que tornam imprescindível um planejamento urbano sustentável. Pois os reflexos sócioambientais são evidentes: deficiências de moradias, degradação ambiental e ausência de serviços básicos como um todo.

Esse processo dá-se em cadeia, na qual a acumulação capitalista induz à expansão do espaço urbano e ao crescimento das atividades comerciais e de serviços. Entretanto a respectiva expansão emerge sem uma infra-estrutura adequada a população da cidade.

Assim surgem novas categorias de profissionais e de agentes promotores do espaço urbano; e a conseqüente alteração nas relações de trabalho até então existentes. A cidade passa por transformações político-administrativas no âmbito regional e local. Conseqüentemente, surge a necessidade de incorporar novas regras de uso e ocupação do solo urbano.

Nesta perspectiva, justifica-se a importância do presente estudo em analisar as relações sociais pelas quais a cidade é produzida e o espaço urbano estruturado. Esta relação,como se demonstrará, é essencial para o desenvolvimento de Boa Vista, uma vez que, ao condicionar alocação de pessoas, atividades e equipamentos sobre o território, determinará a forma de organização do espaço urbano.

Neste quadro, pretende-se abrir as discussões sobre o espaço intra-urbano da capital roraimense, que nos relatos, documentos e estudos dão conta da inserção de sucessivas modernidades que retratam a abrangência de sua expressão local como cidade-primaz. 
O recorte temporal inicial de análise será a partir de 1890, quando foi criado o município de Boa Vista do Rio Branco e quando a Vila de Boa Vista do Rio Branco torna-se sede de município - ainda como parte da então província do Amazonas -, permanecendo como vila sede de município até 1926, quando ganha status de cidade, com base nas políticas de colonização, proteção e desenvolvimento da Amazônia Setentrional.

Entre os anos de 1890 e 1943 o crescimento urbano de Boa Vista estava diretamente relacionado a questões geoeconômicas decorrentes da atividade agropecuária e de mineração, que envolvia fazendeiros, indígenas, religiosos, entre outros, ou seja, a economia pautava-se, em sua maioria, na criação de gado para suprir o mercado do Estado do Amazonas e do Pará, e na agricultura de subsistência voltada exclusivamente para o consumo interno, uma vez que o acesso ao núcleo urbano era difícil, pois o transporte de gêneros alimentícios e de bens materiais para prover as necessidades da população era feito por via fluvial. Entretanto, em determinados períodos do ano era feito por via aérea, o que se tornava oneroso.

Até 1943, a produção do espaço urbano de Boa Vista deu-se de forma acanhada, uma vez que o poder local era emanado do Estado do Amazonas e que sua atenção, no período, voltava-se particularmente para estagnação regional da borracha e a tentativa de diversificação das atividades da região. Conseqüentemente, o processo de crescimento urbano da cidade foi lento, pois as políticas de investimentos locais eram escassas, ou seja, era visível a ausência de um ordenamento territorial, isto é, de uma infra-estrutura urbana que contribuísse para qualidade de vida dos citadinos.

Assim, nossa pesquisa está voltada para a complexidade das mudanças ocorridas no espaço urbano de Boa Vista entre os séculos XIX, XX e XXI: período marcado por um forte crescimento sócioespacial. Nesses séculos, as características do tecido urbano foram alteradas em função de diversos fatores, tais como a atividade agropecuária, a mineração, a migração, as políticas de assentamento regional, a reforma administrativa realizada no estado no ano de 2003, entre outros, quando a cidade era visada como entreposto de abastecimento ou, por que não dizer, celeiro de oportunidades.

As mudanças em curso são examinadas em suas especificidades mais imediatas e, por outro lado, em uma perspectiva histórica e geográfica. Dessa forma, 
as características do tecido urbano são vistas como parte de uma dinâmica que se iniciou em 1890, com índice de urbanização quase que inexistente, e que chega hoje a índices consideráveis.

Em decorrência do difícil acesso, a região em questão ficou alheia a qualquer tipo de desenvolvimento urbano por alguns séculos, ficando à mercê de interesses de exploradores e aventureiros; de guarnições militares; de políticas de ocupação da Amazônia Setentrional, que em sua maioria adotavam diferentes formas de uso do espaço geográfico.

Desse modo, nossa problemática está centrada em analisar como esses interesses interferiram na dinâmica de produção do espaço urbano de Boa Vista.

Desta maneira, somos chamados a concordar com Corrêa (1990, p. 71) quando diz que:

A organização espacial acumula formas herdadas do passado. Elas tiveram uma gênese vinculada a outros propósitos e permaneceram no presente, porque puderam ser adaptadas às necessidades atuais, que não mudaram substancialmente ao longo do tempo.

Também com Reis Filho (2006, p. 61), quando o autor faz uma explanação sobre o conceito de tecido urbano e uso coletivo dos espaços, ao afirmar que:

\footnotetext{
[...] as relações de propriedade se definiam formalmente no tecido urbano. Em segundo, que em cada etapa as sociedades procuram organizar suas formas de ação coletiva, seja qual for o modo de dominação. Em terceiro que, mesmo considerando as limitações desse esquema de organização (são sempre combinação de uns poucos elementos) cada sociedade elabora, em cada época, suas próprias formas de tecido.
}

Nesta entropia, a cidade de Boa Vista torna-se um centro polarizador e centralizador das ações políticas de ocupação e colonização do território. Uma vez que as forças políticas (governador, prefeito, fazendeiros entre outros), mão-de-obra qualificada, infra-estrutura física e demais aparelhos públicos e privados estão concentrados na referida cidade.

\section{Objetivos}

Considerando o exposto acima, o objetivo proposto para a tese visa a mostrar como se deu o processo de produção do espaço urbano de Boa Vista. Levando-se em consideração sua importância no contexto geopolítico e estratégico de proteger, ocupar e desenvolver as fronteiras da Amazônia setentrional. 
Para tanto, fez-se necessário contextualizar dentro de uma perspectiva histórico-geográfica o processo de produção do espaço urbano de Boa Vista; identificar os principais agentes políticos, econômicos e sociais responsáveis pela organização sócioespacial desta cidade; gerar mapas temáticos de uso e ocupação do solo a partir da base urbana de Boa Vista, utilizando técnicas avançadas de geoprocessamento; identificar e analisar as ações dos poderes público e da sociedade civil que estão sendo realizadas na atualidade e como estes atuam na promoção do espaço urbano da referida cidade; e mostrar a dinâmica de apropriação da terra em relação ao poder federal, estadual e municipal.

Cabe informar que, para atingir os objetivos propostos, as premissas foram definidas a partir da leitura dos sistemas de objetos e de ações incorporados pelos agentes promotores do espaço urbano, como o gestor público federal, estadual e municipal, especuladores fundiários e instituições privadas entre outros, dentro de uma perspectiva espaço-temporal.

\section{Hipótese}

Parte-se da hipótese de que o processo de produção do espaço urbano de Boa Vista é resultado de ações e intenções de caráter estratégico e geopolítico, num espaço territorial em situação de conflito entre forças políticas e étnico-culturais sobre a apropriação da terra, com o objetivo de ocupar, proteger e desenvolver as fronteiras da Amazônia Setentrional em relação aos países vizinhos, Venezuela e Guiana.

Entende-se que Boa Vista traduz-se como centro polarizador em função da ação militar, que a princípio foi responsável pela racionalidade de ações pontuais no sentido de dotá-la de infra-estrutura, processo que teve início em 1944 com a implantação do plano urbanístico da capital, pelo então governador do Território, Capitão Êne Garcez dos Reis. Também se responsabilizou por sua capacidade de influenciar na criação de outros núcleos urbanos na região em face de sua dimensão territorial em área de fronteira.

Guiando-se por esta suposição, a pesquisa entende Boa Vista como sendo alvo do processo de tomada de decisão que se verifica no território ocupado pela cidade e que afeta diretamente a população que a ocupa, considerando três fatores importantes: 
1. A modificação relativa ao espaço urbano é decorrente de sua polarização em relação aos outros municípios;

2. A relevância da cidade reside no fato de ser um centro difuso de novos investimentos frente à sua situação geopolítica e estratégica; e

3. As tensões e os conflitos étnico-culturais que determinaram as condições de uso e ocupação da cidade.

\section{Revisão da literatura}

Como afirma Scarlato (2005), o desenvolvimento de todo trabalho de pesquisa científico exige a clareza de seus pressupostos teóricos e metodológicos, pois representam seus alicerces.

Desta forma, foram utilizados como referencial teórico as obras de autores que têm estudado a relação espaço-tempo, com o objetivo de se compreender a produção do espaço urbano de Boa Vista em diferentes momentos históricos do processo de construção e reconstrução da cidade. Entre esses autores estão: Milton Santos, Francisco Capuano Scarlato, Maria Laura Silveira, Roberto Lobato Corrêa, Manuel Castells, Vera Rezende, Flávio Villaça, Yara Vicentini, entre outros. Conhecendo essa literatura, poder-se-á compreender a cidade de Boa Vista como uma realidade sócioespacial definida na atua temporalidade.

Dentre as diversas abordagens acerca do tema, sobressai-se aquela referente à produção do espaço, caracterizando-a como um processo de transformação realizado pela sociedade com o objetivo de atender às necessidades em contínua reestruturação. O processo de Produção é permanentemente acompanhado pela reprodução e reorganização do espaço, uma vez que o homem está sempre procurando e encontrando novas técnicas para acumular capital e ampliar a força de trabalho.

Desse modo, o espaço torna-se fluido, permitindo que os fatores de produção, o trabalho, as mercadorias e o capital passe a ter uma grande mobilidade (SANTOS, 2005). O desenho urbano passa, então, a ser compreendido a partir dos subprocessos econômicos, políticos e sócio-culturais nos diversos momentos de sua dinâmica de produção. 
Boa Vista, desde o período colonial, tem despertado interesses diversos, não só dos governadores e autoridades brasileiras, como também de estudiosos, autoridades internacionais, religiosos e de aventureiros em busca de riquezas naturais e minerais. Depois da criação do Território Federal do Rio Branco, Boa Vista deixou de ser um simples povoado provinciano, parte do Estado do Amazonas, para se estabelecer como uma cidade independente político e administrativamente. Pela sua posição estratégica no vale do rio Branco, passou a ligar-se e a subordinarse diretamente ao Ministério da Justiça e Negócio Interiores.

Nesse sentido, pode-se afirmar, com base em Carlos (2007, p. 26), que pensar o espaço do ponto de vista de sua produção envolve, necessariamente, refletir sobre a abrangência do significado do termo "produção", na medida em que esta noção abarca sempre aquela de reprodução. Faz-se necessário, ainda, salientar que a produção impõe formas e ritmos à vida e às atividades dos homens, pelo simples fato de ser indispensável à sobrevivência do grupo social.

Apoiado em Santos (1985), o estudo remeter-nos-á às seguintes questões: o que caracteriza, particularmente, a abordagem da sociedade através da categoria espaço? Como, na teoria e na prática, levar em conta os ingredientes sociais e naturais que compõem o espaço, para descrevê-lo, defini-lo, interpretá-lo, e, afinal, encontrar o espacial? Como levar em conta a questão da periodização e da difusão das variáveis, e o significado das localizações?

No caso da produção do espaço da cidade de Boa Vista, uma variável a ser analisada é como se deu a implantação do plano urbanístico em 1944; e outra, é identificar o seu significado para o espaço urbano regional e a dinâmica de organização de espaço urbano da cidade. Refletir-se-á, portanto, sobre o espaço de morada do homem, que, conforme indica Corrêa (1993), deve ser pensado considerando-se suas conexões com o tempo, pois tempo e espaço reúnem toda a experiência humana.

Como centro político e administrativo, a cidade de Boa Vista caracteriza-se como um espaço de novas ocupações humanas e sociais ao longo de sua formação sócioespacial. O meio urbano torna-se local de conflitos em sua configuração espacial, isto é, a estratificação sócio-econômica da população constitui-se como importante fator de determinação e localização dos equipamentos e serviços. Se, por um lado, indivíduos mais abastados financeiramente ocupam pontos privilegiados do meio urbano, em geral bem servidos de infra-estrutura; por outro, as 
camadas sociais de baixa renda residem em áreas desprovidas de condições básicas de sobrevivência.

Estas formulações aliam-se às transformações na divisão do trabalho e à criação de necessidades sociais de uma sociedade, com o espaço geográfico constituindo-se em formas-conteúdos. Desse modo, as mudanças em curso estão sempre buscando novos significados, na medida em que o movimento social thes atribui, a cada momento, frações diferentes de transformações de todo social (SANTOS, 1985).

Todavia o simples registro de transformações espaciais não é suficiente para caracterizar a estruturação ou reestruturação do espaço urbano de Boa Vista. É necessário mostrar como essas mudanças em determinado setor da estrutura incitam alterações em outros setores.

Um caso típico dessa (re) estruturação da cidade foi a inserção das Universidades públicas e privadas a partir de 1990. Nesse período, o mercado imobiliário teve um salto expressivo no setor, visto que houve uma supervalorização das áreas próximas a esses estabelecimentos de atividades educativas, que, aliás, fomentaram, por exemplo, a construção de estâncias ${ }^{1}$ e de condomínios fechados destinados aos estudantes, professores e funcionários públicos, entre outros, que buscam moradia próxima às instituições de ensino.

Ao se definir a periodização a ser utilizada para analisar o processo de produção do espaço urbano de Boa Vista a partir de três momentos de sua formação sócioespacial, retrata-se, na concepção de Moreira (1993), a dialética do espaço, em que a articulação estrutura-conjuntura pode ser expressa nos seguintes termos: a estrutura econômica da formação econômico-social é que determina a organização espacial, mas é a conjuntura política que comanda seus movimentos (processos e forma)

De 1890 até a década de 1960, a dinâmica sócio-econômica de Roraima esteve ligada, quase exclusivamente, às medidas político-administrativas e ao desenvolvimento urbano de Boa Vista. O rio Branco, dada a falta de rodovias, as quais, durante décadas, resumiam-se ao trecho precário Boa Vista - Caracaraí, continuou a exercer importante papel no desenvolvimento econômico e no

\footnotetext{
${ }^{1}$ Nome dado a moradias conjugadas, construídas para aluguel e compostas por uma suíte e uma pequena cozinha.
} 
povoamento do território, possibilitando as relações comerciais de Boa Vista com Manaus e outros centros urbanos.

Para Castells (1979), a compreensão da evolução e da problemática de um conjunto urbano deve partir da análise da sua estrutura, para explicar a relação entre diferentes situações estruturais existentes nos problemas urbanos.

Rezende (1982), por sua vez, ao tratar sobre o processo de produção do espaço urbano, dá ênfase à articulação entre os elementos fundamentais do sistema econômico, que, segundo a autora, são:

Produção: Conjunto de atividades de produção de bens e serviços. Ex: indústria e escritório.

Consumo: Conjunto de atividades relativas à apropriação social, individual e coletiva do produto. Ex: Habitação equipamentos coletivos.

Intercâmbio, entre produção e consumo. Ex: Circulação e comércio.

Gestão, regulação das relações entre produção, consumo e intercâmbio. Ex: Plano de urbanismo, organismos de planejamento urbano, instituições municipais, entre outros.

$\mathrm{Na}$ opinião da autora estes elementos do sistema urbano são, na verdade, intervenções de agentes sociais sobre elementos materiais. As combinações entre eles dependerão das leis estruturais da sociedade em que o espaço urbano está incluído. Esse espaço urbano ou unidade espacial, como define Castells (1979), será transformado pelas relações entre diferentes elementos: produção, consumo, intercâmbio e gestão.

Em relação à cidade de Boa Vista, Lessa (1991, Apude VALE, 2005) afirma que até meados da década de 80, época em que possuía uma população de 70.532 habitantes, o processo de urbanização da cidade foi planejado pelo Governo Central, que, visando à segurança nacional, articulou o crescimento do Território mediante uma política de desenvolvimento urbano concentrada na capital com a implantação dos equipamentos e serviços.

Por sua localização próxima a Venezuela, a cerca de $200 \mathrm{~km}$ pela BR 174, e infra-estrutura urbana muito superior à das cidades Venezuelanas e guianenses da fronteira, a cidade de Boa Vista configura-se como apta a centralizar funções de organização de setores, o que a torna porta de entrada norte na Amazônia brasileira (VALE, 2005, p. 72). 
Logo, para se entender a produção do espaço urbano de Boa Vista, faz-se necessário realizar uma abordagem histórica e, assim, periodizar as sucessivas alterações no espaço urbano da cidade. Como escreve Silveira (1999, p. 96), "uma periodização impõe-se como regra de método fundamental, pois permite distinguir pedaços coerentes de tempo nos quais um novo arranjo territorial revela uma modernização material e organizacional".

Reforçando as palavras de Silveira, Santos (1990) assevera que a análise do espaço não poderá ser feita sem que duas premissas essenciais sejam estabelecidas:

\begin{abstract}
O tempo não é um conceito absoluto, mas relativo, ele não é resultado da percepção, trata-se de um tempo concreto; ele não é indiferenciado, mas dividido em secções, dotada de características particulares. Somos desse modo, levados a encontrar uma periodização, baseada em parâmetros capazes de ser empirizados e a considerar esses parâmetros não como dados individuais, mas em suas inter-relações. Seguindo essa linha, chegaremos à identificação de sistemas temporais.
\end{abstract}

As relações entre os períodos históricos e a organização espacial também devem ser analisadas; elas nos revelarão uma sucessão de sistemas espaciais na qual o valor relativo de cada lugar está sempre no correr da história.

Nesse sentido, o espaço geográfico define-se como união indissolúvel de sistemas de objetos e sistemas de ações, sendo suas formas híbridas as técnicas (SANTOS, 1996) que indicam como, onde, por que e para quê o território é usado. Adotando tal ênfase nas técnicas, pode-se privilegiar uma história sistêmica do território em foco, delimitar períodos e redescobrir os respectivos contextos (SANTOS \& SILVEIRA, 2001).

Desse modo, organizar um encadeamento que possa entender a produção do espaço urbano em Boa Vista significa um esforço de construção de modelos de explicação sobre a emergência de novas modalidades de organização territorial, como parte de mudanças sociais.

Como diz Villaça (1998, p. 72), o espaço urbano é produto produzido; não é, portanto, dom gratuito da natureza; é fruto de trabalho social. Logo, o valor do espaço é diferente do valor dos elementos que o constituem (edifícios, ruas, infraestrutura, entre outros). Conseqüentemente, o valor de uso reside na propriedade que tem o próprio espaço urbano de fazer com que se relacionem entre si e os diferentes elementos da cidade. 
Assim, para analisar a produção do espaço urbano de Boa Vista, propõe-se demarcar em três períodos:

Primeiramente, o período que vai de 1890 até o ano de 1943, durante o qual a morfologia, a estrutura, a organização e os movimentos da formação sócioespacial não eram mais que a transformação de formas extraídas da primeira natureza, sob a forma de matérias-primas brutas e alimentos em meios de subsistência. O capital era circulante e dependente em relação ao estado do Amazonas, que se articulam numa sucessão de escalas de relação de dominânciadependência.

Em seguida, o período da integração das instâncias política e ideológica no interior da superestrutura, sobretudo em fase da onipresença cada vez maior do Estado nas formações econômico-sociais na Amazônia setentrional, voltado exclusivamente para as relações de poder, desenvolvimento e controle das fronteiras da região norte do país. Nesse período, mais precisamente em 1943 foi criado o Território Federal do Rio Branco, pelo então Presidente da República, Getúlio Dorneles Vargas.

E, por fim, no período em que se verificou, estampada na paisagem, a estrutura de classes, isto é, o caráter de classes da organização do espaço, passando-se a perceber com clareza uma formação de múltiplos espaços desiguais. Os objetos do arranjo espacial tornaram-se mais visíveis na paisagem, isto é, os fixos e fluxos articulam-se como processo de reprodução, como instrumentos de trabalho e meios de consumo individual e coletivo na cidade, como explica Santos (1994). No transcorrer desse período, foi criado o estado de Roraima, com a Promulgação da Constituição Brasileira de 1988.

Essas rugosidades levam a se trabalhar a cidade não somente no plano de sua materialidade, mas também no da subjetividade. Uma vez que as transformações sócioespaciais de determinada cidade são produtos de processos históricos. Lembrando Milton Santos, pode-se compreender o espaço como acumulação de tempos desiguais, ao mesmo tempo em que somos orientados a desvendar os diferentes significados que a cidade nos apresenta (SCARLATO, 2005).

Evidencia-se em nosso estudo a necessidade de uma análise que privilegie a relação espaço-tempo, na medida em que procuramos compreender a dinâmica de 
produção do espaço urbano de Boa Vista em momentos distintos do processo de construção e reconstrução da cidade.

A propósito, Silveira (1999) chama atenção para a importância de se saber qual é a melhor maneira de contar a história do território, na qual se inclui a história do presente, o que impõe a necessidade, para usar as suas palavras, de "encontrar um caminho, quer dizer, também, descobrir o que é moderno em cada período histórico" (SILVEIRA, 1999, p. 21-26). Tal assertiva conduz à compreensão de que se encontram diferentes modernidades em diferentes períodos da história do território.

A autora avança na discussão entendendo que a periodização é que permite dar valor às coisas, podendo ser concretizada a partir de uma variável ou do conjunto delas. Os sistemas técnicos possibilitam entender, a um só tempo, os objetos, as formas de ação e de organização e as normas, elementos constitutivos do espaço geográfico.

Os sistemas técnicos inseridos no contexto urbano da cidade não são unos, isto é, esses elementos técnicos não chegam todos por igual em determinado lugar, mas em parcelas, caracterizando uma faceta da verticalidade com vistas a interesses particulares, os quais impõem um novo ritmo e forma de pensar a configuração territorial da cidade.

O espaço urbano de Boa Vista tem sido, no decorrer dos tempos, destinado a cumprir funções específicas que mudam de acordo com as necessidades e interesses das organizações sociais e políticas das classes dominantes que se revezam no poder. Diante desta perspectiva, a cidade, inacabada e em transformação, é resultante de intervenções reguladas por diferentes agentes promotores do espaço urbano. O resultado é a valorização do solo urbano, que atinge o máximo no centro principal e nas áreas nobres da cidade (setor Leste), e vai diminuindo até atingir um mínimo nos limites da cidade (setor Oeste).

Desse modo, dois lotes de terra localizados no arruamento histórico elou no setor Leste da cidade possuem um valor maior que um terreno de mesma área localizado na periferia (setor Oeste), cujo valor é afetado pelos custos de transporte e infra-estrutura.

Por meio da análise das diversas ações e intencionalidades historicamente dadas, pretende-se mostrar a necessidade de se ligarem estrutura social e formas espaciais para se compreender o processo de produção da cidade, em particular, 
quando se trata do discurso político proferido nas campanhas eleitorais, o qual é usado como instrumento de permanência de determinadas elites locais no poder e, causando, concomitantemente, o conflito que marca o seu domínio sobre o espaço urbano da cidade.

Um caso que exemplifica bem a questão diz respeito à implantação do loteamento Conjunto Cidadão no setor Oeste da cidade, pelo governador do estado de Roraima em 2002, Flamarion Portela, que, em sua campanha eleitoral, fez a promessa de, no ano de 2002, construir mil casas em um único dia, com o objetivo de amenizar o déficit habitacional existente na capital. Tal promessa, todavia, não passou de um discurso político no intuito de garantir sua reeleição. Reeleição esta que foi conquistada, mas que durou apenas dois anos, já que, em 2004, Flamarion Portela foi destituído de seu cargo após sofrer um processo de cassação. Contudo é importante destacar que as casas foram construídas não em um único dia, mas ao longo de sua permanência no governo.

O processo de produção do espaço urbano de Boa Vista é coerente com o modo de produção dominante, embora apresente uma desordem. Ao espaço são acrescidos infra-estrutura, sistema viário e equipamentos, que, com a falta ou presença de amenidades compõem o valor da terra. A cidade torna-se, então, um potencial de consumo exatamente como qualquer outro produto.

Torna-se oportuno, portanto, observar como se faz a cidade, como se produz o espaço e, por conseqüência, como as classes de baixa renda se localizam nesse espaço.

Corrêa (1993) salienta que é a ação humana que gera a organização do espaço, isto é, que origina forma, movimento e conteúdo de natureza social sobre o espaço. É nesses termos, segundo o autor, que deve ser pensada a produção do espaço urbano pelo geógrafo interessado em compreender uma organização social que revela práticas de apropriação, de extração de rendas e conceitos associados ao espaço.

Neste raciocínio, Castells (1976, p. 75) comenta que:

O espaço, longe de se organizar aleatoriamente, já se encontra estruturado e os processos sociais referentes a essa estrutura são determinados por períodos diversos de diferentes organizações sociais. Dessa forma, o espaço não está desligado da estrutura social, que determina aos agentes sociais uma apropriação diferencial do produto de seu trabalho e, como conseqüência, determina diferentes possibilidades de consumo. 
O espaço se organiza segundo a estrutura de classes do lugar e, uma vez assim organizado, reverte sobre essa mesma estrutura, sobredeterminando-a. (MOREIRA, 1993).

Em Boa Vista, os serviços urbanos se irradiam do centro para a periferia, tornando-se cada vez mais escassos à medida que essa distância aumenta - esse é o caso, por exemplo, da distribuição de água da cidade. Paralelamente, a mobilidade sócioespacial torna-se um problema, pois as vias de comunicação entre o centro e a periferia não acompanham o crescimento e a expansão da cidade, ao mesmo tempo em que os meios de transporte não satisfazem a demanda local; na verdade, nem mesmo existe transporte de massa na cidade.

Rezende (1982) observa que, na ânsia de resolver os problemas da cidade, o poder público, a quem cabe a gestão do consumo coletivo, opta por ordenar a cidade, disciplinando o aparente caos, pois, no que se refere ao espaço, a crise urbana e/ou produção deste aparece como um planejamento não-planejado. Nesse sentido, são elaborados os planos de urbanismo, cujo objetivo é organizar o espaço urbano e também minimizar os conflitos.

$\mathrm{Na}$ cidade de Boa vista, a intervenção do poder público, ao longo dos períodos pré-estabelecidos para a investigação, não foi coerente com os desejos e anseios da coletividade. O que se pode verificar, por exemplo, observando-se que, na alocação de infra-estrutura, os planos agem enfatizando as desigualdades sociais, isto é, criam infra-estruturas e equipamentos em áreas já ocupadas por uma população de alta renda, aumentando ainda mais a segregação social e o maior valor da terra no local.

Vetter e Rzezinsky (1979, p. 65) colocam que:

\begin{abstract}
A concentração espacial dos grupos de renda mais alta, gera uma espécie de causação circular no sistema urbano, não somente pela sua maior demanda efetiva pelos serviços, como também, porque esses grupos possuem normalmente maior poder político para influenciar as decisões de investimentos governamentais em seu favor. Como conseqüência, dar-se-ia a subida de valor do solo urbano exatamente nesses locais já privilegiados.
\end{abstract}

Na concepção de Vicentini (2004), essa concentração espacial representa estratégias de apropriação e domínio territorial; de construção e expansão das cidades; de consolidação de novos agentes de apropriação e de novas formas de sua expressão, introduzindo modos de vida que retratam embates e conflitos de tempos diferenciados. 
Portanto é imprescindível que se entendam as diferentes formas de como os subespaços são dominados na cidade de Boa Vista, e que se identifiquem os agentes que atuam sobre eles, transformando-os de acordo com seus interesses econômicos, políticos, sociais e ideológicos ao longo de sua formação sócioespacial.

Nesta lógica, é fundamental se adquirir-se uma noção do todo, ou seja, os acontecimentos devem ser analisados dentro de um contexto geral, considerando-se todos os aspectos sociais importantes, nenhum deles tendo primazia sobre os outros (SANTOS,1990).

Santos \& Silveira (2001, p. 99) dizem que:

O uso do território pode ser definido pela implantação de infra-estrutura, para
as quais estamos igualmente utilizando a denominação sistemas de
engenharia, mas também pelo dinamismo da economia e da sociedade. São
os movimentos da população, a distribuição da agricultura, da indústria e dos
serviços, o arcabouço normativo, incluídas a legislação civil, fiscal e
financeira, que justamente com alcance e a extensão da cidadania,
configuram as funções do novo espaço geográfico.

Por isso, a produção do espaço urbano de Boa Vista será analisada por meio das quatro categorias de análise propostas pelo professor Milton Santos: forma, função, estrutura e processo. A utilização de tal metodologia é reforçada pelo professor Trindade Jr. (1997), segundo o qual o processo de produção de uma cidade ocorre porque, a cada novo momento da divisão do trabalho um novo movimento é atribuído à sociedade, mediante o qual se assinala um novo elenco de funções e, simultaneamente, ocorre uma alteração qualitativa e quantitativa das funções antigas.

Todavia devem-se considerar, ainda, os apontamentos sobre a estruturação do espaço feitos por Villaça (1998, p. 72), que afirma ser o espaço intra-urbano, ao contrário do regional, estruturado fundamentalmente pelas condições de deslocamento do ser humano, seja enquanto portador da mercadoria força de trabalho - como no deslocamento casa/trabalho -, seja como consumidor reprodução da força de trabalho.

Os processos espaciais presenciados na cidade de Boa Vista nos últimos oito anos chamam a atenção para as novas ações realizadas por um conjunto de forças postas por determinados agentes. Trata-se da dispersão comercial, isto é, o centro comercial (arruamento histórico) não exerce mais sua hegemonia comercial. O setor 
comercial passa a procurar novos eixos de localização e relocalização, como as Avenidas Ville Roy, Ataíde Teive, das Guianas, entre outras.

$\mathrm{Na}$ concepção de Corrêa (1990), estes objetos fixos ou formas dispostas espacialmente (formas espaciais) estão distribuídos elou organizados sobre a superfície da terra de acordo com alguma lógica. Logo, o conjunto de todas essas formas configura a organização espacial da sociedade.

\section{Técnicas de pesquisa}

Certos de trilharmos um caminho que nos leve ao nosso objetivo, traçamos alguns métodos e técnicas de pesquisa que são parte da construção deste trabalho.

$\mathrm{Na}$ presente pesquisa, o caminho do método será a imersão do arranjo espacial no jogo de suas determinações múltiplas. Em outras palavras, buscar-se-á apreender a partir do arranjo espacial - sendo este a expressão fenomênica da estrutura da formação econômico-social -, a dinâmica de produção do espaço urbano de Boa Vista em cada período de sua formação sócioespacial, em particular a partir de 1944; e conhecer as contradições que o regem em sua organização, as quais nos põem no movimento do conhecimento da própria dialética da formação. Por essa razão, segundo Moreira (1993), o espaço organizado é uma formação sócioespacial.

Dessa forma, com base em Santos \& Silveira (2001, p. 54), as preocupações do estudo centrar-se-ão na "[...] categoria - espaço, tal qual ela se apresenta, como um produto histórico, sendo os fatos referentes à gênese, ao funcionamento e à evolução que nos interessam em primeiro lugar".

Parte-se do pressuposto de que a escolha de um conceito deve se adequar à proposta de pesquisa, estando de acordo com o tema que se pretende desenvolver. Nesse sentido, procura-se analisar a produção do espaço urbano de Boa Vista, por meio do enfoque histórico e da perspectiva espaço-temporal, de modo que possa relacionar a origem da cidade e suas motivações iniciais com os processos históricos, econômicos e políticos. Isso evidencia que a periodização espacial é a recomposição do tempo, pondo em destaque os instantes distintos que marcam o pleito de apuramento da organização espacial do objeto em estudo.

Entende-se, com isso, e segundo Moreira (1993), que se devem apreender as leis internas que governam as formas e as estruturas, usando estas como leituras 
daquelas. Estas formulações, de acordo com Vicentini (2004), colocam-se na perspectiva de uma maior aproximação da tese sobre o objeto, acrescendo-se a especificidade e fragmentação da organização social e histórica contemporânea à compreensão da transformação da Amazônia brasileira em uma fronteira urbana.

No caso de Boa Vista, os pressupostos se baseiam numa análise da maneira como se processou a produção do espaço urbano, procurando relacionar a estrutura atual da cidade com a dinâmica de sua formação sócioespacial.

Neste caso, Abreu (1988, p. 69) considera que,

Um trabalho que vise analisar o processo de evolução de qualquer cidade a partir de sua organização atual é, por definição, um estudo dinâmico de estrutura urbana. Para que evite cair no empirismo da mera descrição geográfica, é necessário, entretanto, que, ele relacione - a cada momento a organização interna da cidade como processo de evolução da formação social. Só assim será possível integra padrão e processo, forma e função, espaço e tempo.

Para a realização da pesquisa, buscamos várias fontes de informações, como pesquisa bibliográfica, documental, entrevistas e coleta de dados nos diferentes órgãos públicos da cidade.

A pesquisa bibliográfica foi orientada de forma a recuperar o conhecimento já elaborado e publicado sobre a realidade local, assim como subsidiar a formação de conceitos básicos que foram utilizados no decorrer do trabalho e forneceram dados secundários em várias etapas do processo da pesquisa.

A pesquisa documental - relatórios, mensagens oficiais, planos urbanos, programas, mapas, fotografias, arquivos, jornais, entre outros - tornou possível a identificação das diversas intervenções urbanísticas realizadas em Boa Vista, bem como o zoneamento e a dinâmica de produção e uso do solo urbano da área em estudo.

Com base nas informações obtidas, nos dados cartográficos e em modernas técnicas de geoprocessamento, foi elaborado mapas temáticos da dinâmica de produção do espaço urbano da cidade.

Tal metodologia, segundo Vicentini (2004, p. 25), demonstra a diversidade de processos e formas de ocupação para o longo período considerado, alertando para a amplitude das abordagens que foram desenvolvidas; para a análise do objeto e suas perspectivas.

Espera-se, portanto, que os dados coletados e analisados sejam instrumentos balizadores para mostrar que a produção do espaço urbano de Boa Vista é 
decorrente de iniciativas do Estado, ou seja, de políticas de ocupação, exploração de uma área estratégica, vinculada a interesses geopolíticos na Amazônia setentrional.

\section{Estrutura dos capítulos da tese}

O presente estudo foi dividido em três momentos. Partimos de uma análise sobre o processo de ocupação do vale do Rio Branco, refletindo sobre a Vila de Boa Vista do Rio Branco, sua dinâmica de formação sócioespacial, as atividades fundadoras do sítio urbano, dinâmica e estruturação político-administrativas e a formação do sítio urbano.

Em seguida, partimos de uma reflexão sobre a formação sócioespacial de Boa Vista a partir da criação do Território Federal do Rio Branco, sobre os processos políticos de produção do vale do rio Branco; sobre a realidade sócioespacial do Território - primeira ação política do Governador Êne Garcez dos Reis para justificar a necessidade de implantação do Plano Urbanístico na cidade, mostrando também as obras de urbanização realizadas na cidade, bem como as características do traçado radial concêntrico.

Por fim, o terceiro capítulo reflete sobre o Território Federal do Rio Branco (Roraima) face às ações político-administrativas de desenvolvimento da Amazônia e a relação dele com o processo de produção do espaço urbano de Boa Vista; a dinâmica intra-urbana de Boa Vista a partir da implantação do plano urbanístico de 1944; a produção de Boa Vista com a transformação do Território Federal de Roraima em Estado, em 1988; O Planos Diretor da cidade; e as rugosidades e tendências atuais na dinâmica urbana de Boa Vista. 


\section{CAPÍTULO I: PROCESSO DE OCUPAÇÃO DO VALE DO RIO BRANCO}

Neste capítulo, é explicitado o processo de ocupação do vale do rio Branco, bem como os caminhos seguidos para a formação sócioespacial da Vila de Boa Vista do Rio Branco e sua inserção no cenário amazônico de forma dependente e isolada do resto do país. Desvenda-se a dinâmica de produção de Boa Vista a partir de um período em que a morfologia, a estrutura, a organização e os movimentos de sua produção e (re) produção não são mais que a transformação de formas extraídas do setor primário e da pecuária em meios de subsistência, isto é, de capital circulante e dependente da então província do Amazonas, posteriormente estado do Amazonas, que se articulam numa sucessão de escalas de relação de dominância-dependência que vai até o ano de 1943, quando é criado o Território Federal do Rio Branco pelo Presidente Getúlio Vargas.

\subsection{Processos político e produção do vale do rio Branco}

As razões políticas que conduziram as estratégias de integração territorial do atual estado de Roraima e seu reflexo na dinâmica de produção da cidade de Boa Vista têm início no período colonial - Séc. XVII e XVIII, quando o governo português tratou de estabelecer uma estrutura de ocupação permanente na Amazônia face aos conflitos com os espanhóis, ingleses, franceses e holandeses. Utilizaram-se, inicialmente, as missões religiosas e, em seguida, estabelecimentos governamentais (fortes, aldeias, fazendas entre outros) para reter o indígena e fazê-lo passar a produzir para o mercado interno e externo. Conforme Andrade (2004, p. 23-24), o processo dar-se-ia em função da coleta de drogas do sertão, da captura de índios para serem escravizados e da ação de missões religiosas que procuravam converter o gentio.

Comungando com Andrade (2004), Rezende (2006, p. 06) reitera que a conquista da Amazônia no período colonial, foram empreendimentos conduzidos pelo estado, planejados e executados com prioridade política pelo governo metropolitano [...]. Coube a Portugal, ainda durante a vigência lbérica, sob ordem do rei da Espanha, a expulsão dos franceses de São Luis do Maranhão, e a fundação, em 1616 do Forte do Presépio de Santa Maria de Belém. A partir dessa posição, segundo Rezende (2006) pescadores e comerciantes Ingleses e holandeses, que 
iniciavam sua instalação no baixo amazonas, foram expulsos pelas forças portuguesas.

O processo de ocupação da região amazônica foi realizado por via fluvial e todos os estabelecimentos estavam próximos às margens dos rios, principalmente em pontos de confluências, como foi o caso do Forte São Joaquim e da maioria das fazendas reais localizadas no vale do rio Branco. O povoamento foi disperso, concentrando-se em aldeamentos missionários, em povoações, para onde convergiam os indígenas aldeados ou onde estavam localizados os comércios das chamadas "Drogas do Sertão" (ANDRADE, 2004, p. 34).

No século XVIII, a expansão portuguesa foi ampliada e consolidada ao Norte, com a ocupação da Amazônia, levando o homem e o gado a áreas muito distantes, como o atual estado de Roraima (ANDRADE, 2004, p. 35).

Conforme Santos (2004, p. 10)

\begin{abstract}
A intervenção do Estado na região se iniciou com o marquês de Pombal, na segunda metade do século XVIII, a qual buscava garantir territórios para a coroa portuguesa, construindo fortalezas nas entradas "naturais", isto é, junto a alguns rios, como nos campos do rio Branco, hoje Roraima. Uma segunda intervenção (COSTA, 1992, p. 09) se deu quando da repressão da revolta da Cabanagem (1835-1839), ocasião em que o governo imperial aumentou maciçamente sua presença militar na então província do Pará. Após a metade do século XIX, ocorre o que comumente é conhecido como o "ciclo da borracha", cujo período áureo inicia-se por volta de 1870, decaindo após 1912. Segue-se um período de estagnação até 1940, quando o governo central cria vários órgãos técnicos e de apoio e desencadeia uma série de ações na região. Essas medidas estão ligadas aos denominados "Acordos de Washington" e, segundo Bahiana (1991), foram assinados em plena Segunda Guerra Mundial, quando a borracha e outros produtos estratégicos foram extremamente valorizados.
\end{abstract}

Durante o período imperial e a República Velha, a Amazônia esteve predominantemente à margem dos eixos principais da economia e da sociedade nacional. A presença do Estado Nacional e das políticas públicas na região, com raras exceções, inexistiu, concretamente, em todos os sentidos (SILVA, 2008, p. 01-09) ${ }^{2}$.

Para Oliveira (1988), o processo político e a produção do território na região amazônica estar inserido dentro de quatro momentos:

a) Século XVII - expansão portuguesa -, quando os índios que viviam de uma economia de subsistência e de comércio intertribal passaram a defrontar-se com

\footnotetext{
${ }^{2}$ Consultar: Artigo: Raízes amazônicas, universidade e desenvolvimento regional. Autor: Silva, Fábio Carlos da. 2008. Doutor em Educação, Professor do Programa de Pós-Graduação em Educação da Faculdade de Educação - FACED/ Universidade Federal do Amazonas - UFAM. Site eletrônico: www.desenvolvimento.gov.br
} 
uma economia de produção para um mercado externo, com a escravização de sua gente, com a ação catequizadora dos missionários e com a perda de seus valores culturais. Os colonos, por seu lado, para sobreviver tiveram que adaptar-se à tecnologia;

b) Século XVIII - Ação de Francisco Xavier de Mendonça Furtado -, quando foi posta em prática, na Amazônia, a política pombalina. Nesse período, as aldeias missionárias deram origem às cidades e vilas da Amazônia e a pressão para o aportuguesamento e integração do índio à sociedade colonial tornou-se maior. Ocorreram fatos como: a demarcação de limites; a abertura de um caminho para Mato Grosso através de navegação nos rios Amazonas, Madeira e Guaporé; a criação da Capitania de São José do Rio Negro e a criação do Diretório dos Índios, em substituição à atuação dos missionários;

c) Século XIX - Expansão causada pela procura da Borracha - quando a Amazônia começa a perder sua face indígena diante do grande fluxo migratório em decorrência do desenvolvimento da indústria da borracha. Nessa época, o índio deixa de ser a mão-de-obra essencial e é desalojado violentamente de seu território. Crescem também as fronteiras do Brasil com a anexação do Acre. Além disso, esse processo de expansão gerou um aumento demográfico para a região Amazônica.

Nesse período, a ação do governo da província do Amazonas, os pecuaristas, as ordens religiosas, e a camada pobre da população (aqui inclui os indígenas residentes em Boa Vista) constituíam os principais agentes promotores do espaço da Vila de Boa Vista do Rio Branco. A realidade sócioespacial estava pautada nos setores da agropecuária, extrativismo mineral (garimpo) e constituía-se, ainda, enquanto espaço de defesa da fronteira Norte do país.

A Vila era pequena e com uma reduzida densidade demográfica, revelava, desde então, clara tendência de não ocupação da margem esquerda do rio Branco, diferentemente da margem direita, que foi habitada inicialmente nas áreas não alagáveis. A Vila expandia-se tendo em vista os terrenos de cotas mais altas. Porém, sem nenhum procedimento técnico e de forma desordenada.

Os terrenos urbanos estavam sob o domínio do governo territorial do Amazonas, o qual concedia aos habitantes, comerciantes, fazendeiros, religiosos entre outros, que ali se instalavam. Porém, com o passar do tempo, os referidos terrenos foram legalizados pelos seus proprietários. Sendo a União, o governo 
municipal, os comerciantes, os fazendeiros, os religiosos e as famílias influentes os principais proprietários fundiários da Vila de Boa Vista.

Coube ao Estado Nacional, controlado pela elite local, a tarefa de direcionar e (re) planejar a Vila de Boa Vista, de impulsionar o setor produtivo, bem como de criar alternativas de sobrevivência a vida social da população local, de maneira a tornar conveniente a organização sócioespacial da Vila;

d) Século XX - Ação das políticas desenvolvimentistas para a Amazônia inauguradas nos anos 60, quando essa região passou a comunicar-se, via terrestre, com o Centro-Sul, em especial com a capital Federal que, naquela época, foi transferida para Brasília. Com essas políticas iniciou-se a mais forte investida de expansão interna na área Amazônica, liderada por grandes grupos empresariais. Assim, a integração econômica, territorial e social do atual Estado de Roraima no século XX, consistiu numa estratégia do estado que agiu, interferiu e produziu o seu espaço, como forma de criar condições para atender ao interesse da ocupação, reprodução e expansão do capital na fronteira (SILVA, 2007, p. 46).

Neste momento, dá-se uma nova fase na dinâmica urbana das cidades capitais da Amazônia, com a inserção de ações (atividades produtivas diferentes da agropecuária) por meio do estado e de empresas privadas, acarretando um processo intenso de migração do meio rural para o urbano e, ao mesmo tempo, definindo novas formas de produção e (re) produção do espaço urbano das cidades amazônicas.

Reforçando o exposto, acima, Corrêa (1989, apud TRINDADE JR.1997, p. 45) advoga que:

O crescimento das cidades capitais amazônicas, expressa, por um lado, a criação de novas atividades urbanas pelo estado e pelas empresas privadas e, por outro lado, a profunda decadência e transformação das atividades agropecuária e extrativista, que passam a desencadear correntes migratórias no sentido rural-urbano, definido formas marcantes de apropriação do espaço da cidade e de constituição de sua paisagem, a exemplo da produção de favelas elou futuras favelas. 


\subsection{Vila de Boa Vista do Rio Branco - uma questão em discussão}

O processo de produção da Vila de Boa Vista do Rio Branco em 1890, posteriormente cidade em 1926, estar em consonância com a (des) construção do espaço, ou seja, assim como um processo de supressão e emergência de formas e funções que atenderam às necessidades, em um dado momento, da divisão social do trabalho e das relações de acumulação de capital.

Acredita-se, que a dinâmica de produção de Boa Vista tenha ocorrido a partir do surgimento de novas funções que se adequaram às formas de outrora ou criaram formas novas, reorganizando-se a circulação de idéias e mercadorias e redefinindose, por meio da divisão técnica do trabalho, novos espaços de produção e consumo (GODOY, 2004, p. 29-32).

Todavia a emergência de novos arranjos espaciais não suprimiu integralmente as formas do passado em Boa Vista, mas, as renovaram através das novas funções que adquiriram na articulação do território. Ao mesmo tempo, fizeramno objetos de um sistema de ações econômicas, políticas e sociais. O propósito disso era gerar condições materiais de produção, capacidade de controle e também dotar a Vila de equipamentos urbanos.

Nesta dinâmica sócioespacial, a produção do espaço é produção de objetos que articulam e organizam, em suas funções específicas, intercâmbios sociais que envolvem o trabalho e a produção. O espaço seria, neste caso, a materialidade e a mediação entre os sistemas de produção, de controle e reprodução do trabalho em sua dimensão técnica e material (GODOY, 2004, p. 32-38). Em poucas palavras, o espaço seria um sistema de sistemas ou, como quer Santos (2002), "sistemas de objetos" e "sistemas de ações".

$\mathrm{Na}$ ótica de sua produção, o espaço torna-se a dimensão empírica da organização das ações que o produz. Como advoga Godoy (2004, p. 38-42)

A organização das ações emerge, por sua vez, de uma estrutura normativa e reguladora cujo movimento é dado pelos processos de transformações resultantes das relações entre trabalho e capital. Isto significa que as formas espaciais produzidas contêm elementos das partes e do todo, como também elementos novos surgidos da generatividade dessas relações. A natureza mutante das relações sociais traz, por sua vez, mudanças na organização dos "sistemas de ações" e, portanto, na eficácia da funcionalidade das formas - nos "sistemas de objetos. 
Para Andrade (1987, p. 37), desde as épocas mais remotas, o homem costuma dividir o espaço de acordo com características que apresentam em suas várias porções, levando em conta, sobretudo, as características oriundas da influência das condições naturais e do aproveitamento do espaço. Corrêa reafirma a importância dessas condições naturais e históricas como expressão da organização espacial e da região ao afirmar que:

Região e organização espacial são também materialidades sociais,
expressões concretas da história, isto é, resultam das relações mutáveis
entre o homem e entre este e a natureza. E, como materialidades sociais,
passam a fazer parte das condições da reprodução social
(CORRÊA, 1990, p. 51).

As principais marcas dessa reprodução social são observadas na estrutura da economia e na organização do território, que envolve uma diversidade de atores sociais.

O espaço produzido, na percepção de Andrade (1987, p. 20), "é um espaço social e não um espaço natural", mesmo porque, hoje, já não existem mais espaços genuinamente naturais, pois estes se localizam apenas naquelas áreas onde o ser humano não interveio de forma intensa. O espaço geográfico, para o mesmo autor, é eminentemente social, uma vez que, à proporção que o ser humano evoluiu em termos tecnológicos, a sua capacidade de modificar o meio ambiente acelerou-se.

No caso de Boa Vista, ela deve ser entendida como uma realização humana, uma criação que vai se constituindo ao longo do processo histórico de sua formação; de fazenda para povoado, de povoado para freguesia, de freguesia para vila e sede municipal, posteriormente cidade.

Assim, para Carlos (2007, p. 57),

A cidade, em cada uma das diferentes etapas do processo histórico, assume formas, características e funções distintas. Levando-se em conta a sua organização política, a estrutura do poder da sociedade, a natureza e repartição das atividades econômicas e as classes sociais.

Portanto pensar Boa Vista e sua produção no âmbito da geografia é pensar a partir da dinâmica do território construído, no jogo político da vida cotidiana, individual e coletiva, ou seja, da sociedade em movimento, em processo de constituição de fluidez, como assevera Carlos (2007, p. 90) que ao tratar da produção da cidade, diz que: 
Pensar a cidade e sua produção é pensar a partir da espacialidade das relações sociais em sua natureza social e histórica.

Dessa maneira, Boa Vista é um lugar que abriga, produz e reproduz. É como reforça Cavalcante $(2001$, p. 15) ao analisar a cidade como um espaço geográfico:

A cidade é um espaço geográfico, é um conjunto de objetos e de ações, mas entendendo que ela expressa esse espaço, como lugar de existência das pessoas, não apenas como um arranjo de objetos tecnicamente orientados.

\subsubsection{Caminhos para sua formação sócioespacial}

Iniciamos essa discussão colocando que, em 1770, após o conflito territorial entre portugueses e espanhóis pelo domínio da região, a abrangência portuguesa no vale do rio Branco foi consolidada, levando adiante, na concepção de Bonnato (2002, p. 84), os planos de instalar uma fortificação militar que defendesse e resguardasse a integridade dessa zona de conflitos internacionais. Tal concepção encontra reforço na afirmação de Santilli (1994): "[...] Foi uma ocupação marcadamente estratégico-militar em virtude de ser uma região limítrofe às possessões espanhola e holandesa nas Guianas, [...] e via de acesso às bacias dos rios Orinoco e Essequibo".

Farage (1991, p. 123), por sua vez, comunga com tais asserções ao afirmar que:

[...] a ocupação efetiva do rio Branco tornou-se uma questão central para os portugueses [...] entre 1775 e 1776 os militares iniciaram a construção do Forte São Joaquim, à margem direita do Tacutu, no ponto de junção deste rio com o Uraricoera para formar o rio Branco, posição esta recomendada pelos estrategistas portugueses por permitir o controle da passagem de ambos os rios $[\ldots]$.

Essa região chamada de vale do rio Branco tem como principal marco o rio Branco, que nasce da confluência dos rios Tacutu e Uraricoera (Mapa 1). Para Barros (1995, p. 13), o rio constituía o eixo principal de penetração para a ocupação da região nos séculos $X V I I, X V I I I, X I X$ e até a segunda metade do século $X X$, quando foi inaugurada a rodovia federal BR 174, que interliga Boa Vista a Manaus e Venezuela. 


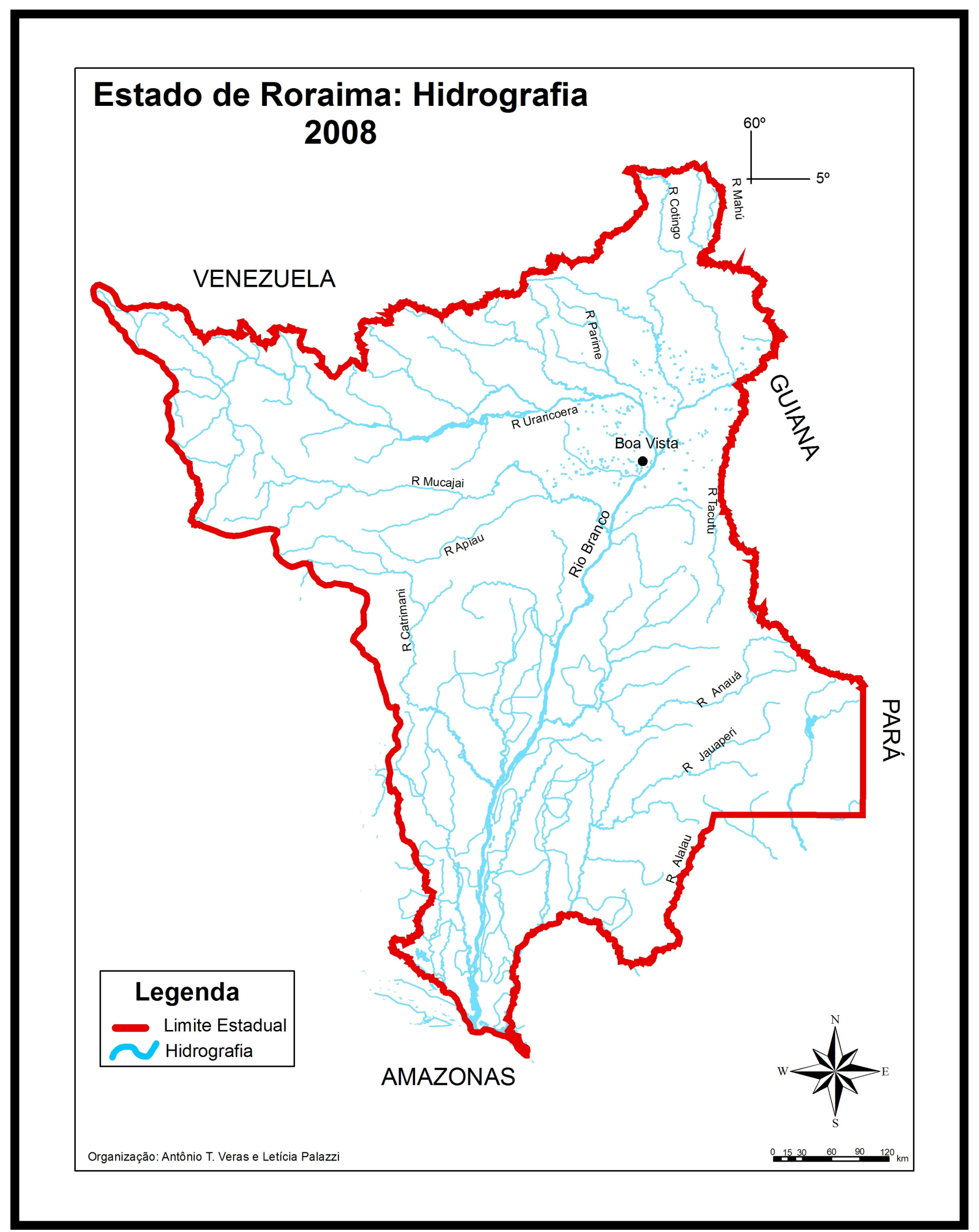

Mapa 1: Localização do rio Branco

Fonte: Mapa do Zoneamento Econômico Ecológico de Roraima. Secretaria de Planejamento SEPLANIRR - 2000. 
Todos os povoados existentes ao longo do rio Branco foram incorporados à Capitania de São José do Rio Negro (atual Estado do Amazonas), fundada em 1755, consolidando em definitivo o processo de ocupação e domínio português na região.

A construção do Forte de São Joaquim (Figura 1) teve grande importância no processo de ocupação da região do rio Branco, em especial do alto rio Branco (Campos Gerais), uma vez que concentrou um número significante de população nas aldeias que ficavam em seu entorno, e que, posteriormente, em alguns casos, passariam a constituir parcela da população da fazenda Boa Vista.

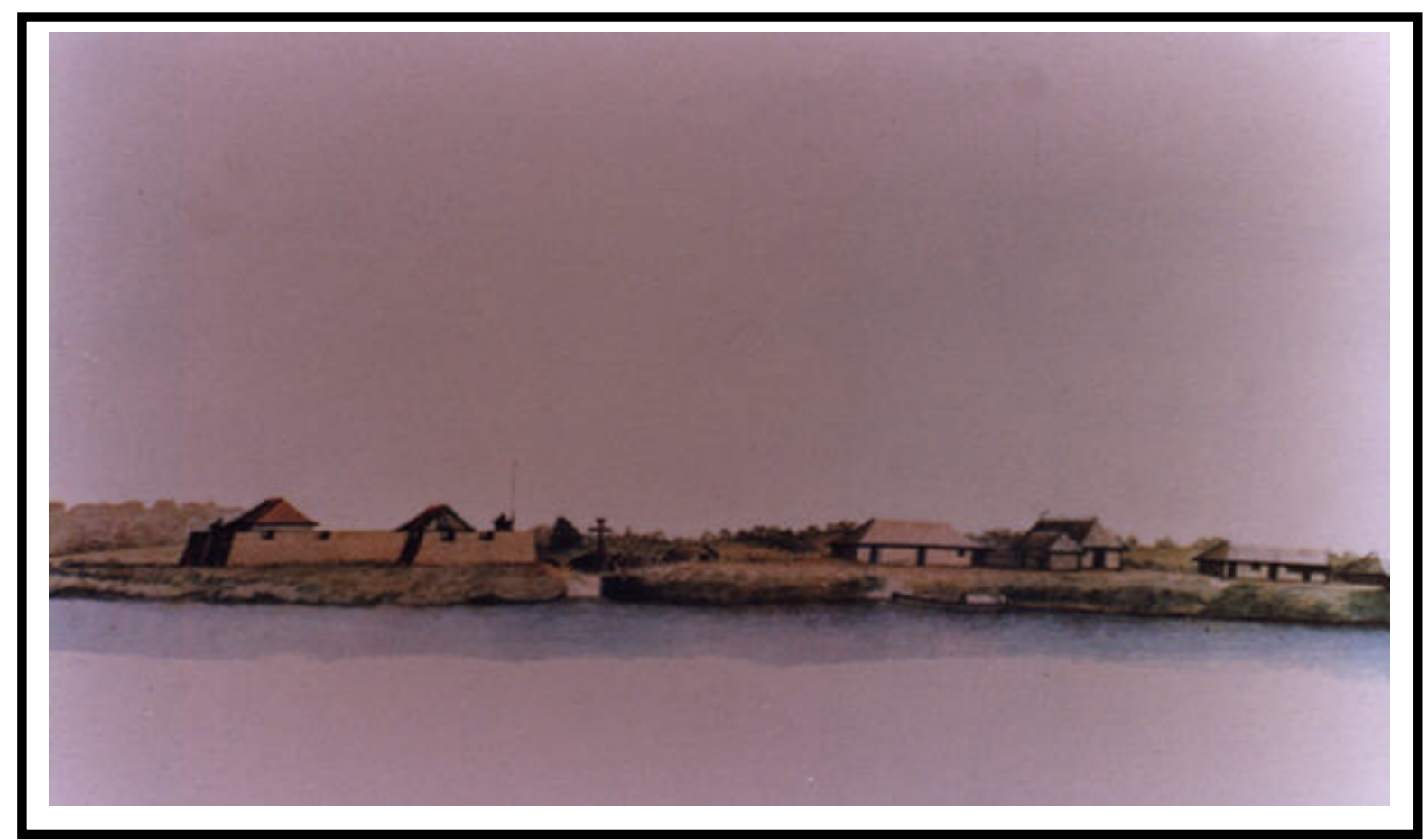

Figura 1: Forte São Joaquim

Foto: Acervo de Waldir Paixão (Aquarela feita durante a expedição comandada por Alexandre Rodrigues Ferreira \Séc. XVIII).

Reforçando o exposto, Barbosa (1993, p. 125) considera que:

A partir desse momento da história, foi possível considerar o início de uma modesta, porém politicamente determinada ação colonizadora nesta região. A instalação da base militar foi apenas parte de um plano que previa a formação elou consolidação de núcleos populacionais constituídos basicamente por nativos. Estes núcleos tinham por função principal "habitar" para que junto com a força pública instalada, resguardassem a região do Brasil Colônia em nome da coroa portuguesa.

Antes mesmo do fim das obras do Forte São Joaquim, em 1777, o capitão Philipe Sturm, em conjunto com as missões religiosas, estabeleceu cinco povoações, ou melhor, aldeias, ao redor da fortaleza, cuja população chegava a cerca de 1000 índios (GUERRA, 1957, p. 127). As povoações de Nossa Senhora do 
Carmo, Nossa Senhora da Conceição, São Philipe, Santa Bárbara e Santa Izabel eram povoadas pelas etnias dos grupos indígenas Paraviana, Macuxi, Wapixana, entre outras.

A povoação de Nossa Senhora do Carmo estava localizada na margem ocidental do rio Branco, em frente à foz do rio Uanuasú. A de Nossa Senhora da Conceição situava-se na margem sul do rio Uraricoera. A de São Philipe, por sua vez, estava na margem oriental do rio Tacutu, próxima ao Forte São Joaquim; e as de Santa Bárbara e Santa Izabel, abaixo da união dos rios Uraricoera e Tacutu. (SAMPAIO, 1850)

Segundo indica Barbosa (1993, p. 125), algumas dessas localidades já existiam desde 1725, estabelecidas pela entrada de Missionários Carmelitas do Rio Negro, que as erguiam sob o molde de "aldeias de repartição" ${ }^{3}$. Para o autor, estes povoamentos, a partir de 1755, tinham como objetivo aumentar as trocas comerciais com o resto da então fundada Capitania de São José do Rio Negro.

Outro meio de ocupar e dominar o vale do rio Branco, na compreensão de D'almada (1787, Apud COSTA, p. 168), seria incentivar os soldados a se casarem com as índias do território ocupado, dando-Ihes donativo de algumas vacas e éguas.

O referido autor afirmava, que a inserção do gado vaccum nos campos do rio Branco, foi um fator preponderante no desenvolvimento do comércio ao interior da capitania, uma vez que acarretaria diversas vantagens: primeira, iria suprir o mercado de carne na capital e evitar matança exagerada de tartarugas ${ }^{4}$, que serviam como alimento aos habitantes da região [...]; segunda, suprir de carne seca as diferentes povoações da capitania em que há trabalhos públicos; terceira, o aproveitamento do couro na capitania sairia a melhor preço aos seus habitantes [...]; quarta, cresceriam as rendas reais com os dízimos do gado, e com o imposto sobre a carne destinada aos açougues [...]. Com base nessas vantagens, demonstra-se 0 quanto é conveniente e necessária a introdução do gado vaccum nos imensos campos do rio Branco (D'ALMADA, 1787).

Esta ação, na apreciação de Barbosa (1993, p. 128), seria uma das possibilidades de estimular não só a escassa população civil, mas também a

\footnotetext{
${ }^{3}$ Tinham como objetivo aldeiar os índios em povoamento sob a influencia religiosa, facilitando os ensinamentos e promovendo o desenvolvimento de uma economia agrícola e pesqueira baseada na força de trabalho indígena.

${ }_{4}^{4}$ Percebe-se nesta frase do autor a sua preocupação pela a preservação da espécie. Fato que merece um estudo mais aprofundado sobre a defesa das tartarugas no período.
} 
população indígena a permanecer nos núcleos instalados. Além de propiciar melhores condições de sobrevivência aos seus habitantes e um maior povoamento da região.

Para o autor supracitado, o processo de colonização e ocupação do vale do rio Branco pode ser compreendido a partir de quatro momentos:

O primeiro momento dá-se a partir da instalação das aldeias de repartição e, posteriormente, com a política dos diretórios de índios, missionários religiosos da Ordem dos Carmelitas, militares e nativos a serviço da coroa portuguesa foram responsáveis pelo o papel de polícia ao poder colonial, mesmo que em pequena escala.

No segundo momento, a dinâmica de ocupação e colonização é marcada pela fracassada política pombalina; que visava uma ocupação territorial [...]. Nesta ação, conjeturava-se a inserção de gado bovino como elemento de incentivo a fixação de índios e brancos na região. Porém este ato só foi presenciado com maior intensidade ao final do século XIX.

$\mathrm{O}$ terceiro momento intensifica-se no interstício dos séculos XIX e XX, quando a economia do vale do rio Branco era voltada exclusivamente para a pecuária de corte. Esta fase coincide com o declínio econômico da Amazônia em decorrência da queda dos preços nas exportações de borracha. [...]. O papel dos religiosos seria marcado por um novo comportamento diante da população indígena local. A ação deste abalou a relação de subserviência dos índios diante do poder feudal instalado nesta localidade por grupos de fazendeiros e comerciantes.

$\mathrm{O}$ quarto momento seria marcado pelo início de frentes migratórias frente à atividade mineral e pela ação do poder central na tentativa de retirar esta região do vazio demográfico. Estimulado pelo nacionalismo, o Presidente Getúlio Vargas decretou a criação do Território Federal do Rio Branco (hoje Roraima), por ocupar local estratégico na fronteira Norte.

Esta ação viria acompanhada de medidas que proporcionariam uma infraestrutura local para incentivar a vinda de colonos à nova unidade federada (BARBOSA, 1993, p. 141).

Neste cenário, se situa a ocupação do vale do alto rio Branco, de cunho estratégico e geopolítico, com o objetivo de povoar, proteger e desenvolver as fronteiras da Amazônia setentrional. Os portugueses utilizavam os espaços ocupados pelos nativos, obrigando-os ao trabalho forçado em fazendas de gado e a 
tarefas domésticas. Porém, os povos indígenas não concordavam com a escravidão; como conseqüências, ocorreram conflitos e extinção de algumas tribos da época pela apropriação da terra.

O homem colonizador usava de sua influência para incorporar um conteúdo social ao meio natural (exploração e degradação dos recursos naturais, escravização dos indígenas, inserção da agropecuária entre outros), impondo leis à natureza. Com o frenesi do mandar e do fazer, "os princípios que comandavam o funcionamento harmonioso do meio, por parte dos indígenas, foram substituídos por uma intencionalidade" (SILVEIRA, 1999, p. 36) dos colonizadores em explorar o vale do rio Branco. De qualquer modo, o gado deveria ocupar as terras dos autóctones, dando lugar às fazendas que se ligavam ao sistema de extração da borracha na província do Amazonas.

Desta forma, a "transformação do meio natural foi heterogênea, pois eram diversos os graus de desenvolvimento técnico e cultural dos diversos grupos" (SILVEIRA, 1999, p. 35). Como conseqüência, a configuração territorial foi alterada em conformidade com as necessidades sócioespaciais do período.

Os assentamentos humanos e sua dinâmica sócioespacial fundavam-se nas ofertas da natureza preexistente. Era, desse modo, "um território caracterizado pelos tempos lentos, onde as diferenciações enraizavam-se na natureza e um tempo humano buscava timidamente ocupar os alvéolos de um tempo "natural" (SANTOS \& SILVEIRA, 2001, p. 30).

As tribos eram nômades, devido a alguns fatores: a terra para o plantio que, cansada, os obrigava a se deslocar para outra(s) região (ões); a fuga aos brancos e guerras com outras tribos. Paralelamente, o seu território crescia e, ao mesmo tempo, promovia a ampliação da territorialidade, impulsionada pela desterritorialidade dos grupos que se sentiam prejudicados com a forma e a violência dos colonizadores. Conseqüentemente, com a expansão do território, os grupos indígenas sofriam com os embates culturais que os violentavam, especificamente no tocante ao uso da terra, isto é, à diferença entre a concepção da terra como valor de uso e da terra como mercadoria.

Os governadores aprovavam pedidos de homens que queriam tomar as terras dos índios, como acontece até hoje, tendo, como única norma, a lei do mais forte (MARTINS \& SALES, 1995, p. 09). 
Para Vieira (2003, p. 08-89),

A exemplo de outras regiões do país, onde o Estado não se fazia presente, o município de Boa Vista, marcado principalmente pelo isolamento, tendo como único meio de acesso o próprio rio Branco, apresentava as seguintes características: as embarcações e a maioria de suas terras eram monopolizadas pelos coronéis Bento Brasil, Cordeiro Saldanha da Cruz e ainda pelo grande latifundiário e comerciante de Manaus, J. G. Araújo. Analisando-se por esse ângulo, no Rio Branco o poder acabava concentrando-se nas mãos dos grandes proprietários de terra, repetindo-se 0 sistema de poder baseado nos coronéis que, por longos anos deram sustentação à República Velha, que também brigavam entre si para saber quem teria o direito as migalhas do poder central.

Em relação aos religiosos, Vieira (2003, p. 92-93) afirma que foram retirados do município após inúmeros conflitos com os fazendeiros ficando condicionados a retornar à sede municipal face às alianças que supostamente teriam que ser feitas com os respectivos fazendeiros. Essas alianças tinham como meta a obtenção do sucesso na catequese dos povos indígenas e o desenvolvimento econômico do vale do rio Branco.

Em 1892 foi criada a primeira Paróquia da Região do Rio Branco, (LUCKMANN,1989, p. 13-14). A ação religiosa tinha um papel fundamental na dinâmica sócioespacial da vila. Para Rice (1978, p. 25), a influência das freiras e dos monges Beneditinos em Boa Vista era explicita nas relações sociais e familiar, pois o grau de moralidade é elevado; a população branca e os mamelucos são verdadeiramente civilizados.

Neste arcabouço, Boa Vista, encontra-se marcada pela presença do colonizador português, espanhol, do fazendeiro, do indígena, do migrante e do religioso no alto rio Branco, com o objetivo de ocupar, explorar e proteger as fronteiras da Amazônia setentrional.

Tal processo torna acertiva a visão de SANTOS \& SILVEIRA (2001, p. 28), quando dizem que:

A presença do homem já atribui um valor às coisas, que, assim, passam a conter um dado social. Por outra parte, como toda ação supõe uma técnica, a idéia de meio geográfico não pode ser desvinculado dessa noção de técnica. 
O modelo de ocupação realizada na Amazônia setentrional não mediu esforços em explorar os diferentes espaços territoriais, criando hiatos regionais, diferenciados em sua configuração territorial. No caso de Boa Vista, a diferenciação deu-se em função de sua posição estratégica e geopolítica em relação aos países da Venezuela e Guiana; e também por meio dos equipamentos e serviços preexistentes no contexto espaço-temporal vigente.

Certas rugosidades espaciais deste período sobrevivem nas fazendas de gado, nos costumes indígenas, na ação religiosa, na mineração (exploração descriminada dos recursos minerais), entre outros. O que denota uma importância para a compreensão da formação sócioespacial de Boa Vista, enfocada no Quadro 1, que mostra uma periodização dos processos de produção do espaço urbano de Boa Vista que serão enfocados nos capítulos propostos nesta pesquisa. 


\begin{tabular}{|c|c|c|c|c|c|}
\hline Temporalidade & $\begin{array}{c}\text { Produção } \\
\text { econômica e } \\
\text { sua orientação } \\
\text { de mercado }\end{array}$ & $\begin{array}{c}\text { Processo de } \\
\text { ocupação do } \\
\text { espaço } \\
\text { urbano }\end{array}$ & $\begin{array}{c}\text { Dinâmica de } \\
\text { produção }\end{array}$ & $\begin{array}{l}\text { Infra- } \\
\text { estrutura } \\
\text { básica }\end{array}$ & $\begin{array}{c}\text { Integração do } \\
\text { espaço } \\
\text { urbano }\end{array}$ \\
\hline $\begin{array}{c}\text { Ocupação desordenada } \\
(1830-1890)\end{array}$ & $\begin{array}{l}\text { - Criação de gado. } \\
\text { - Cultura de subsistência. } \\
\text { - Extrativismo vegetal } \\
\text { visando o mercado } \\
\text { interno e externo } \\
\text { (especiarias). }\end{array}$ & $\begin{array}{l}\text { - Expulsão dos } \\
\text { indígenas. } \\
\text { - Implantação de } \\
\text { fazendas de gado. } \\
\text { - Missões religiosas. } \\
\text { - Criação da fazenda } \\
\text { Boa Vista. }\end{array}$ & $\begin{array}{l}\text { - Criação da Freguesia de } \\
\text { Nossa Senhora do Carmo. } \\
\text { - Criação de vilas, em } \\
\text { particular, da Vila de Boa } \\
\text { Vista do Rio Branco. } \\
\text { - Exploração e posse da } \\
\text { terra pela coroa } \\
\text { portuguesa. } \\
\text { - O Frei José dos Santos } \\
\text { Inocentes e Joaquim do } \\
\text { Espírito Santo, bem como } \\
\text { o Capuchinho Gregório } \\
\text { José Maria de Bêne } \\
\text { exercem o ministério do } \\
\text { Rio Branco. } \\
\text {-Comissão de Limites } \\
\text { Venezuela \Brasil, } \\
\text { chefiada por Francisco } \\
\text { Xavier Lopes de Araújo. }\end{array}$ & $\begin{array}{l}\text { - Abertura de } \\
\text { estradas vicinais. } \\
\text { - Construção dos } \\
\text { primeiros prédios } \\
\text { oficiais. } \\
\text { - Dominância do } \\
\text { transporte animal e } \\
\text { fluvial } \\
\text { - inexistente } \\
\text { (saneamento). }\end{array}$ & $\begin{array}{l}\text { - Exploração de uma } \\
\text { estrada contornando a } \\
\text { zona encachoeirada } \\
\text { do rio Branco e a } \\
\text { abertura de picada. } \\
\text { - Fraga integração } \\
\text { com a província do } \\
\text { amazonas e o } \\
\text { restante do território } \\
\text { brasileiro e fronteiriço. } \\
\text { - Sistema de } \\
\text { telecomunicações } \\
\text { inexistente } \\
\text { - Suprir demanda de } \\
\text { alguns produtos de } \\
\text { interesse da coroa } \\
\text { portuguesa. }\end{array}$ \\
\hline $\begin{array}{l}\text { Ocupação Gradual } \\
(1890-1943)\end{array}$ & $\begin{array}{l}\text { - Exploração mineral } \\
\text { descriminada visando o } \\
\text { mercado externo. } \\
\text { - Investimentos } \\
\text { expressivos na } \\
\text { agropecuária visando o } \\
\text { mercado interno e } \\
\text { externo }\end{array}$ & $\begin{array}{l}\text { - Construção da } \\
\text { Igreja de São } \\
\text { Sebastião. } \\
\text { - Construção de um } \\
\text { curral e um } \\
\text { matadouro municipal. } \\
\text { - Criação da } \\
\text { Paróquia de Nossa } \\
\text { Senhora do Carmo } \\
\text { de Boa Vista } \\
\text { - Criação de uma } \\
\text { Escola de Música. } \\
\text { - Criação do } \\
\text { mercado Público de } \\
\text { Boa Vista. } \\
\text { - Inauguração das } \\
\text { Escolas Primárias } \\
\text { "Cel. Bento Brasil" e } \\
\text { "major Terência." } \\
\text { - Incursão da firma } \\
\text { J.G.Araújo em Boa } \\
\text { Vista. } \\
\text { - Instalação da } \\
\text { Escola da Prelazia. } \\
\text { - Instalação do 1ำ } \\
\text { Pelotão de } \\
\text { Fronteiras. } \\
\text { - Instalação do } \\
\text { Mourabar (ponto de } \\
\text { encontro social da } \\
\text { cidade). } \\
\text { - Interiorização } \\
\text { ordenada (sede) e } \\
\text { ruralização do } \\
\text { povoamento } \\
\text { - Multiplicação do } \\
\text { número de núcleos } \\
\text { populacionais. }\end{array}$ & $\begin{array}{l}\text { - A Intendência isenta de } \\
\text { impostos por dois anos os } \\
\text { estabelecimentos de } \\
\text { montagem de } \\
\text { charqueadas e curtumes. } \\
\text { - As fazendas nacionais } \\
\text { passam para a } \\
\text { administração do serviço } \\
\text { de proteção ao índio. } \\
\text { - Criação da Guarda } \\
\text { Municipal } \\
\text { - Criação das Funções } \\
\text { administrativas. } \\
\text { - Criação do Território } \\
\text { Federal do Rio Branco } \\
\text { - Definição dos limites do } \\
\text { Brasil com a então Guiana } \\
\text { Inglesa. } \\
\text { - Estabelecimento de } \\
\text { limites municipais. } \\
\text { - Instalação da Guarda } \\
\text { territorial da República. } \\
\text { - Sucessiva criação de } \\
\text { novos municípios }\end{array}$ & $\begin{array}{l}\text { - ausência de um } \\
\text { ordenamento } \\
\text { territorial. } \\
\text { - Expansão da rede } \\
\text { elétrica urbana. } \\
\text { - Início da } \\
\text { eletrificação } \\
\text { urbana. } \\
\text { - Sistema } \\
\text { rodoviário fraco. } \\
\text { - Transporte aéreo } \\
\text { limitado. } \\
\text {-Predominância do } \\
\text { transporte fluvial e } \\
\text { rodoviário. }\end{array}$ & $\begin{array}{l}\text { - Aumento da } \\
\text { integração } \\
\text { intermunicipal } \\
\text { - Surgimento de uma } \\
\text { estrutura } \\
\text { hierarquizada de } \\
\text { núcleos. } \\
\text { - Criado o Jornal } \\
\text { intitulado: O Rio } \\
\text { Branco } \\
\text { - Tentativa de abrir } \\
\text { uma estrada que } \\
\text { ligasse Boa Vista - } \\
\text { Manaus }\end{array}$ \\
\hline
\end{tabular}

Quadro 1: Periodização da dinâmica de produção sócioespacial de Boa Vista

Fonte: Dados bibliográficos

Organização: Antonio Tolrino de Rezende Veras 


\subsubsection{Atividades fundadoras do sítio urbano}

\section{a) Agropecuária}

Além da presença militar, outras estratégias da coroa portuguesa para criar núcleos populacionais na região do rio Branco, como sublinha Bonnato (2002, p. 87), eram instalar Fazendas Nacionais, que estimulariam a permanência do homem branco na região; e procurar civilizar um número significativo de índios. No final do século XVIII e inicio do século XIX, várias fazendas ou pequenos povoados foram inseridos ao longo das margens dos diversos rios que fazem parte da bacia do rio Branco.

Como explica Santilli (1994, p. 18), aproximava-se o fim do ciclo em que a cartografia política da região era traçada pela configuração espacial dos aldeamentos e aldeias sob influência colonial. Para o antropólogo Santilli, a partir de meados do século XIX, a ênfase da ação oficial recairia sobre um novo fator de povoamento, a pecuária.

Paralelamente, Santos (2004, p. 30) informa que a agricultura regional teve seu impulso inicial com a ação administrativa do Coronel Lobo D'Almada, que, em 1797, dinamizou a cultural do anil e cultivou e colheu no vale do rio Branco uma produção de arroz que, na época, atendeu ao consumo de toda a Capitania de São José do Rio Negro. Aliar a pecuária à agricultura seria uma alternativa rentável dentro da política de ação coordenada por Lobo D'Almada, uma vez que sua verdadeira missão, na avaliação de Santos (2004, p. 31), era fortalecer a política econômica do Império Português, por meio da dilatação do seu comércio interno e externo, com o aproveitamento do potencial existente nos recursos naturais oferecido pelo vale do rio Branco.

As políticas foram implementadas por atos políticos, mediante os quais se objetivava incorporar a região ao mercado interno colonial e promover a atração e fixação de colonos na localidade. Assim, algumas fazendas particulares de gado começaram a aparecer em áreas próximas ao rio Branco, fundadas principalmente por militares do Forte São Joaquim e por alguns migrantes vindos do Nordeste e da própria região Norte (BONATTO, 2002, p. 88). 
No final do século XVIII, o governo português implantou, na área de campos e savanas, as três fazendas estatais, que inicialmente foram denominadas Fazendas Reais e posteriormente, Fazendas Nacionais (Brasil Império): São Bento, São José e São Marcos.

A fazenda São Bento compreendia a área entre os rios Caumé, Branco e Uraricoera - ocupando uma extensão de 18000 quilômetros quadrados. No inicio do século XX, toda a área da fazenda estava dividida em fazendas particulares (GUERRA, 1957, p. 169).

A fazenda São José, por sua vez, tinha como limite meridional o igarapé do Surrão, que é afluente do Água Boa, e na sua parte setentrional confinava com os rios Branco e Tacutu (GUERRA, 1957, p. 169). Sua sede constituía o povoado do famoso Forte São Joaquim, em cujo porto, na afirmação de Santos (2004, p. 44), era feito o desembargue de gêneros alimentícios e de todo material destinado ao povoado. Em 1841, assevera Santos (2004:44), o povoado de São Joaquim foi transferido para a vila de Boa Vista e a fazenda anexada à de São Marcos.

A fazenda de São Marcos estava situada na zona formada pelo Uraricoera até Tacutu, com uma área superior a 8000 quilômetros quadrados. Seus limites, segundo Guerra (1957), eram: a Leste o rio Surumu; ao sul os rios Tacutu e Uraricoera; e a Oeste o rio Parimé.

As fazendas localizavam-se acima do ponto onde hoje está a cidade de Boa Vista, ou seja, o povoamento pecuário restringia-se ao alto rio Branco, em faixa subindo em direção aos rios Uraricoera e Tacutu (Mapa 2). 


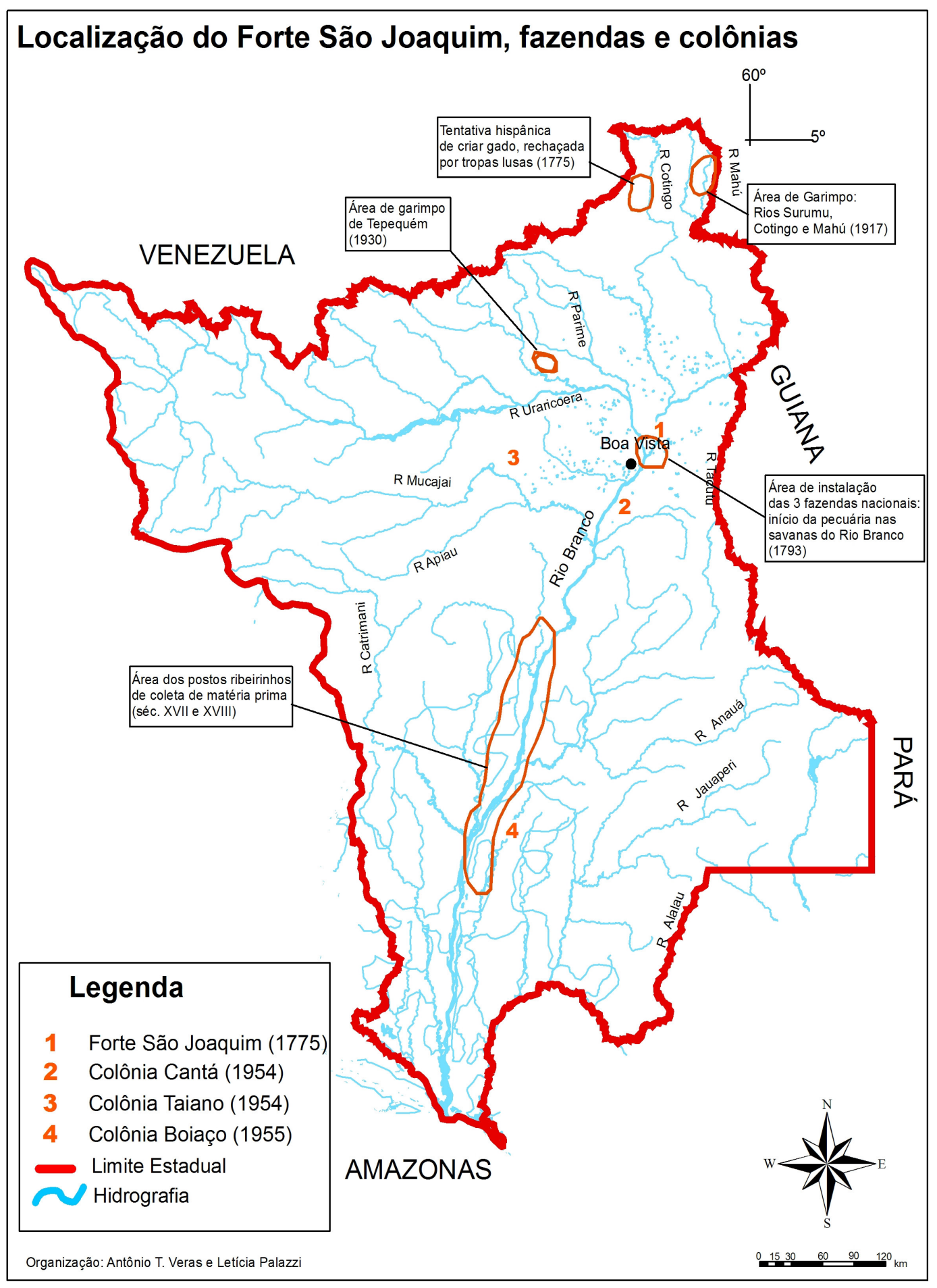

Mapa 2: Localização do Forte São Joaquim, das fazendas e colônias Fonte: Barros, 1995. 
No tocante a população que habitavam as áreas das fazendas, Guerra (1957, p. 27) afirma que, até o início do século XIX, a região era habitada em sua maioria de índios. Porém, com a penetração dos homens brancos e, em particular, com o advento da respectiva pecuária, no séc. XVIII é que o Rio Branco passou a ser habitado pelos não-índios.

Paulatinamente, os campos foram sendo apossados pelos criadores de gado. Em 1843, as antigas Fazendas Nacionais estavam reduzidas a duas, e as fazendas particulares começavam a se multiplicar em suas áreas (BARROS, 1995, p. 68). Salientando, que algumas propriedades eram retiros e os proprietários possuíam mais de uma delas.

Na opinião de Guerra (1957, p. 173), as três Fazendas Nacionais não surtiram os efeitos desejados. Todavia tiveram o mérito de iniciar nessa área de campo a criação de gado, atividade que até meados do século XVIII era inteiramente desconhecida.

A inserção das fazendas nos campos do rio Branco constituiu-se em uma tentativa de se estabelecer uma atividade econômica tradicional que, no transcorrer dos séculos XVIII, XIX e XX, permitiria a fixação dos grupos não indígenas na região, tendo como conseqüência a implantação de instituições semelhantes aos feudos da Idade Média (BARBOSA, 1993, p. 136). Tais instituições eram comandadas por patriarcas das famílias mais influentes da região, que, segundo o autor, exerciam o poder local, criando estruturas que, algumas vezes, sobrepunhamse à força pública e, outras, formavam um só corpo de poder.

Percebe-se, portanto, que a implantação da fazenda Boa Vista em 1830 foi um indicador do avanço da ocupação pecuarista nos campos do rio Branco, uma vez que a população estava exclusivamente voltada para a criação e venda de gado para suprir o mercado local e das regiões do rio Negro e Amazonas. 


\title{
b) Mineração
}

A garimpagem, como prática de riqueza fácil, despertou interesse somente no início do século $\mathrm{XX}$, com o surgimento da atividade mineradora pela descoberta dos garimpos de ouro e diamante nas regiões dos rios Cotingo, Mau, Suapi e Tepequém; o que provocou uma mobilidade intensa de grupos não indígenas para essas áreas. Contudo, na opinião de Barbosa (1993, p. 137), a atividade em questão não foi fator responsável pelo crescimento populacional ou econômico verificado na região nesta época.

Por volta de 1920, com a crise da coleta da borracha, que desestruturou a economia na Amazônia, a pecuária do alto rio Branco perdeu seu principal mercado consumidor. A partir de então, a mineração seria o setor econômico responsável pela relação de Roraima com o exterior.

Segundo Barros (1995, p. 55), pessoas ligadas à coleta da borracha, sem alternativa de ganho, foram atraídas pela possibilidade de mineração do ouro e diamante na região do rio Branco.

\begin{abstract}
Comerciantes e investidores começaram a chegar, e fazendeiros trataram de investir na mineração. A mineração atraiu populações para as áreas ao Norte de Boa Vista, e como antes, era o rio Branco a base da comunicação. Mas estes garimpeiros subiam os afluentes ao Norte deste rio, até às nascentes, como no rio Maú - a nordeste, nos divisores de água com o Rupununi River da Guiana britânica - e, no rio Surumu, ao Norte, nos divisores de água com o rio Caroni da bacia do Orinoco, encontra-se uma velha trilha de garimpeiros, padres e militares da Venezuela que partiam de Angustura (BARROS, 1995, p. 56).
\end{abstract}

Nas décadas de 30 e 60 do século XX, bem como nas décadas de 80 a 90 do mesmo século, respectivamente, a atividade garimpeira sacrificou a pecuária e a agricultura em recursos e força de trabalho, uma vez que criou uma drenagem da renda da mineração para fora do território. (BARROS, 1995, p. 59).

É valido observar que, sendo a cidade de Boa Vista o entreposto da atividade garimpeira, nas respectivas décadas, não se viu nenhuma ostentação de crescimento sócioespacial na cidade. Pelo contrário, havia uma ausência de políticas públicas que controlassem a dinâmica de crescimento desordenado da cidade e a carência de equipamento e serviços à população.

Compreende-se que, em diferentes períodos da história do território, puderam-se verificar diferentes modernidades. Sendo assim, cabe recuperar a indagação e constatação de Silveira (1999, p. 22): 
O que é modernidade no território? A modernidade é o resultado de um processo pelo qual um território incorpora dados centrais do período histórico vigente que importam em transformações nos objetos, nas ações, enfim, no modo de produção [...] Daí falamos em modernidade no plural, porque cada época é definida pelas respectivas modernizações.

As transformações vivenciadas nos períodos estabelecem uma diversidade de formas espaciais e de conteúdo, que evidenciam a complexidade das relações responsáveis pela dinâmica de produção do vale do rio Branco, em particular de Boa Vista, como uma acumulação de tempos e de técnicas diferentes.

\subsubsection{Dinâmica e estruturação político - administrativas: fazenda \freguesia \ vila e cidade}

No ano de 1830, o Capitão do Forte São Joaquim, Inácio Lopes de Magalhães, instalou uma fazenda à margem direita do rio Branco, dando-lhe o nome de Fazenda de Boa Vista ${ }^{5}$, que funcionava como base de uma pequena povoação abastecedora de produtos derivados da pecuária das regiões do rio Negro e do Amazonas; onde, nos tempos primitivos havia a aldeia dos índios Paraviana (REVISTA DIRETRIZES, 199, p. 7). Distando, aproximadamente, $32 \mathrm{~km}$ do Forte São Joaquim.

De acordo com o suplemento especial do Jornal Folha de Boa Vista, publicado em 09 de julho de 2008, página 07(sete), em comemoração alusiva aos 118 anos de aniversário da cidade de Boa Vista, a certidão de registro de Boa Vista deu-se em 18 de setembro de 1850, com o ato da Lei №. 601, conhecida como a Lei das Terras do Império. Foi essa lei que reorganizou os registros das terras rurais nas freguesias $^{6}$.

\footnotetext{
${ }^{5}$ Segundo Silva (2007, p. 197) tem essa denominação em referência a paisagem que a circunda, pois esta foi aclamada por sua grande beleza, formada pelo rio Branco, pelos igarapés, pela vegetação ribeirinha e pelas praias que ali se formam, quando ali se estabeleceram os primeiros desbravadores ou, como relata a história, pela admiração de Inácio Lopes de Magalhães. Em relação ao topônimo Boa Vista, o que se tem são alguns relatos de indígenas a) Kuwy Pire (conjunto de muitas casas) Índio wapichana, 86 anos.b) Uai-Kre (Uai=Buriti / Kre=espécie de bicho de pele que denominava a serra próximo a cidade de Boa Vista). Índio Makuxi, 61 anos.

${ }^{6}$ Para Silva (2007, p. 99-100) a instalação da freguesia nesse aglomerado visava um maior controle administrativo da região, considerando a importância que a igreja católica tinha nas determinações em conjunto com o estado quanto a organização de territórios, entre outras obrigações. [...] $A$ província do Amazonas havia sido criada em 05 de setembro de 1850, ainda no regime do Brasil imperial e oito anos depois, isto é, em 1858 se definia o local para se instalar a freguesia devido à existência do povoado na sede da fazenda Boa Vista. Havia a necessidade de se criar paliativos para o abandono da área setentrional da província e do Brasil [...] Seguindo o rumo comum da história, a instalação da freguesia ocorre a partir da criação da província do Amazonas, que reconhece oficialmente a existência e a importância de um povoado organizado na região.
} 
Em 1858, visando a firmar um maior domínio administrativo sobre a região, o governo, por força da Lei provincial №. 92, de 9 de novembro do referido ano, ao designar as freguesias do Amazonas, estabeleceu que a sede da Freguesia de Nossa Senhora do Carmo seria "acima das cachoeiras do rio Branco, no lugar denominado Boa Vista" (IBGE, 195, p. 5).

Segundo o Jornal Folha de Boa Vista (2008, p. 7) foram feitos seis registros de domínio particular de terras na região do alto rio Branco. Uma dessas áreas era justamente a que passou a chamar-se Fazenda Boa Vista.

No entanto, por meio da Lei №. 132, de 29 de junho de 1865, toda a região compreendida "das corredeiras do rio Branco para o Norte" passou a fazer parte da Freguesia de Nossa Senhora do Carmo, vinculada à Província do Amazonas, Município de Moura (LUCKMANN, 1989, p. 8).

Assim, dada sua especificidade como região de fronteira, em 9 de julho de 1890, por força do Decreto Estadual №. 49, o então Governador da Província do Amazonas $^{7}$, Senhor Augusto Ximênes de Villeroy, criou o município de Boa Vista do Rio Branco, elevando a Freguesia de Nossa Senhora do Carmo ao status de Vila, com a designação de Vila de Boa Vista do Rio Branco, sede do então município criado a partir do território do município de Moura. No entanto sua instalação segundo o IBGE (1951, p. 10) verificou-se somente no dia 25 de julho do mesmo ano.

Após o Decreto de criação do referido município, o Governador da Província do Amazonas, mencionado acima, designa o seu representante, o Capitão Fábio Barreto Leite, para dar posse às primeiras autoridades do município. No dia 25 de Julho de 1890, toma posse o Sargento João Capistrano da Silva Mota como Superintendente e primeiro prefeito da história de Boa Vista, Francisco Coelho e José Joaquim de Souza Junior como intendentes (vereadores) (REVISTA DIRETRIZES, 1991, p. 8).

Um fato interessante é que antes mesmo de assumir o cargo de superintendente, o Senhor João Capistrano da Silva Mota, ainda como militar, fundou a primeira escola da região. Também, foi o primeiro a ocupar todas as

\footnotetext{
${ }^{7}$ Com a Proclamação da República, em 1889, o Estado brasileiro se reorganiza em conformidade com o novo regime político. Com isso, houve a transformação das antigas províncias em estados da federação constituídos de municípios.
} 
posições de maior relevância na Vila de Boa Vista do Rio Branco: professor, juiz de paz e promotor de justiça (REVISTA DIRETRIZES, 1991).

Em relação à formação judiciária, a Lei estadual no. 7 de 21 de setembro de 1892, criou-se a comarca que, no quadro de divisão territorial de 31 de dezembro de 1936, é composto exclusivamente da denominação Boa Vista do Rio Branco, subsistindo no quadro de divisão territorial até o dia 31 de dezembro de 1937, quando a comarca se denomina Rio Branco e tem por sede a cidade de Boa Vista do Rio Branco (IBGE,1951, p. 11). No qüinqüênio 1944-1948, o termo judiciário de Boa Vista é o único componente da comarca de igual nome.

Subordinada ao Estado do Amazonas até o ano de 1943, Boa Vista não detinha a função de sede de decisões políticas. Era somente um apêndice, uma ponta de ocupação. A povoação era uma malha com três ruas paralelas à margem do rio Branco (BARROS, 1995, p. 55). Conforme mostra o Mapa 3.

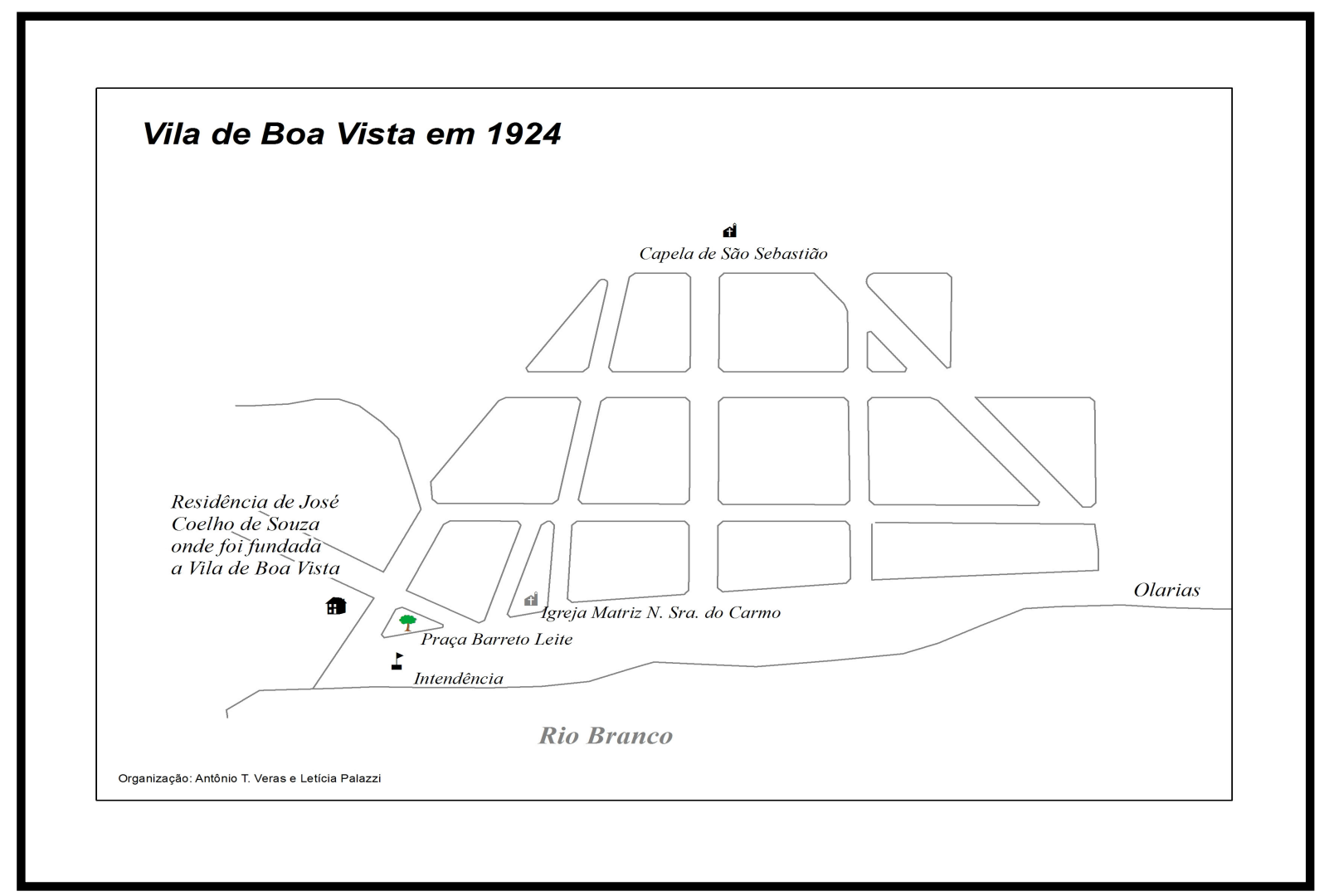

Mapa 3: Planta da Vila de Boa Vista do Rio Brancol1924

Fonte: Brasil, 200. 
No dia 27 de agosto de 1926, o Governador do Amazonas, Doutor Ephifânio Ferreira Sales, concedeu foro de cidade à sede municipal, em cumprimento à Lei estadual $n$ ‥ 1262. Ainda sobre a jurisdição do Estado do Amazonas, a vila passou a ser cidade de Boa Vista. O organograma 1, abaixo, sintetiza melhor as informações supracitadas.

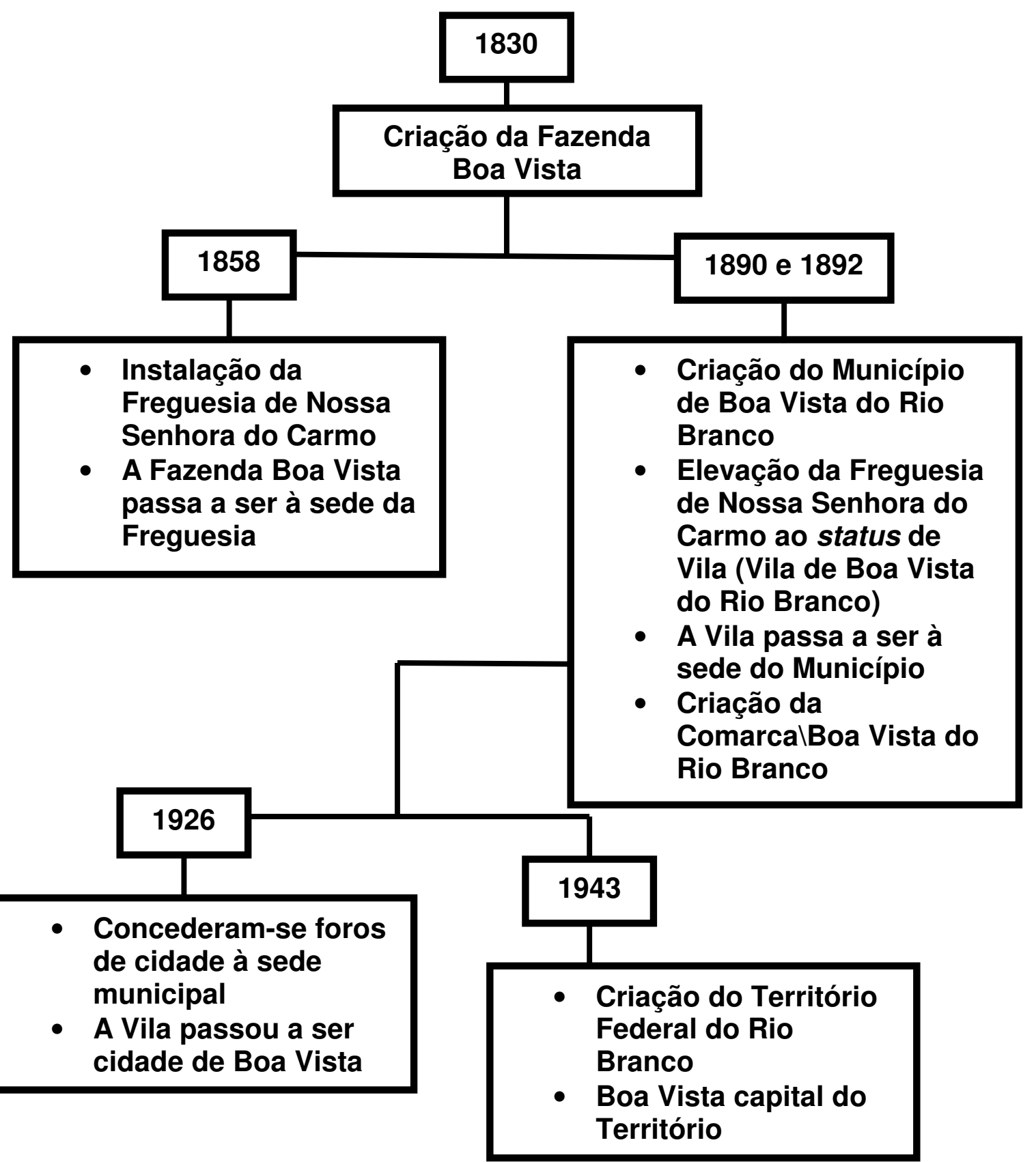

Organograma 1: Periodização da dinâmica político-administrativa de Boa Vista Fonte: Dados bibliográficos

Organização: Antonio Tolrino de R. Veras 
Boa Vista em 1926, possuía uma população escassa, atividade comercial incipiente, sistema de abastecimento d'água realizado de maneira arcaica, isto é, por meio de aguadeiros ${ }^{8}[. .$.$] hotel, cinema, jornal, rádio, biblioteca era apenas um sonho$ (BRAGA,2002, p. 69).

Somente com a criação do território Federal do Rio Branco pelo Decreto - Lei Federal $n^{\circ}$. 5812, de 13 de setembro de 1943, retificado pelo de $\mathrm{n}^{\circ} .5839$, do referido mês e ano, a cidade de Boa Vista passou a ter independência político-administrativa, ao mesmo tempo em que foi elevada à categoria de capital do novo Território. Interessante observar que devido à confusão com o território Federal do Rio Branco$\mathrm{AC}^{9}$, que possuía o mesmo topônimo do Território Federal do Rio Branco, foi instituído o Decreto - lei 4.182, de 13 de setembro de 1962, que mudaria o nome do território Federal do Rio Branco para território Federal de Roraima.

O referido Decreto foi sancionado com base no projeto 1.433, de 18 de janeiro de 1960, de autoria do Deputado Federal Valério Caldas de Magalhães, que a principio foi contrário à mudança do nome de Território Federal do Rio Branco para Território Federal de Roraima em razão de sentimentos regionalistas.

A primeira ação política voltada para solucionar o problema teve início com o primeiro Governador do território, o Capitão Êne Garcez do Reis, que delegou o Padre Alcuino Meyer, da Ordem de São Bento, em 1945, para propor ao Congresso Brasileiro de Geografia e Estatística, na cidade do Rio de Janeiro a mudança de nome. (MAGALHÃES, 1984, p. 60-65). A proposta foi rejeitada, posteriormente foi acatada em razão de acordos político-partidários.

Um fato a ser destacado nesse processo foi a participação popular. Por meio de um plebiscito e atendendo a pedido de leitores, o jornal O Átomo da época, realizou o referido plebiscito e foi escolhido o nome Roraima ${ }^{10}$ como sendo o mais

\footnotetext{
${ }^{8}$ Indivíduos que levava a água para abastecer os moradores em tonéis em lombo de animais ou carroças.

${ }^{9}$ Sigla do Estado do Acre.

${ }^{10}$ De acordo com Dorval de Magalhães Magalhães em seu livro Informações Históricas de Roraima. 1986. Nas discussões junto à comunidade e associações era apresentada uma pauta com as seguintes perguntas: a) deve-se mudar o nome Rio Branco? Por que? b) A origem do nome Rio Branco? Que nomes deveríamos discutir? Paraviana, Parima, Roraima, Uialã? c) Quem terá prioridade, nós ou os acreanos? d) A Assembléia reconhece a necessidade de mudança? d) Palavra facultada e) Votação f) Agradecimento e encerramento. Além dessa pesquisa o Deputado Valério Magalhães solicitou um estudo etimológico, considerando-se o fato da inexistência de informações oficiais. Assim, foi coletado elementos na própria fonte, vale dizer, entre os nativos da região. Entre eles destaca-se o "parente Alberto".

1 - Versão: Trata-se de um substantivo composto por outros dois: loroi=caju e imã=serra, montanha, isto é, Roraima=Serra do caju.[...] $2^{\underline{a}}$ Versão: Há quem afirme que Roraima se origina de rorá=verde +
} 
indicado para substituir o nome Rio Branco. [...] houve consultas nas associações: Rotary Clube, Associação Comercial, Associação dos Professores Secundaristas, União dos Estudantes Secundaristas entre outros (MAGALHÃES, 1986, p. 60-65).

No entendimento de Magalhães (1986), havia necessidade de resolver esse problema toponímico. Pois, existiam casos de pessoas que pretendiam ir para Rio Branco-AC, e vieram para Boa Vista do Rio Branco; também devido ao extravio de correspondências e mercadorias (gêneros alimentícios, remédios entre outros) que eram constantes. Assim, a mudança era imprescindível.

\subsubsection{A formação do sítio urbano}

\section{a) Situação e sítio}

Em seu estudo sobre a evolução urbana do Brasil entre os anos 1500 e 1720, Reis Filho (1968) esclarece que a situação de uma aglomeração determina as suas possibilidades de estabelecer relações e, portanto, as funções que poderá desempenhar no conjunto da rede e do processo de urbanização. Para o autor, tal situação está vinculada diretamente com os recursos naturais, bem como à ação do homem ao longo do tempo. Beaujeu - Garnier (1997, p. 76), por sua vez, observa que tal situação está sempre ligada à facilidade de comunicação, seja para explorar, seja para bloquear.

No tocante a Boa Vista, Guerra (1957, p. 136) explica que a cidade esta localizada numa zona plana, de baixa altitude, situada à margem direita do rio Branco, deixando posteriormente a baixa para se desenvolver na parte alta. $\mathrm{Na}$ acepção do geólogo Guerra, esta situação é fácil de ser explicada, uma vez que nas proximidades da margem há grandes alagamentos por ocasião do período chuvoso.

Somos levados a crer, com base em Guerra (1957) que a localização de Boa Vista nessa margem direita do rio Branco deu-se por um aspecto topográfico local,

imã=grande, ou seja, verde Monte, verdão. $3^{\text {a }}$ Versão: $O$ eminente professor de português, Raimundo Nonato Pinheiro, diz: "... outro topônimo que anda por aí errado, até mesmo oficialmente, é o nome do Território de Roraima. O Vocábulo não deriva de "rorá" (verde, mas de rorô(papagaio). O vocábulo rorôima é de origem Taurepã, e significa: o pai, o formador dos papagaios. "Mudar, nesta altura, Roraima para Rorôima, como deve ser o verdadeiro nome desse Território, acho bem difícil. Dizem os franceses: Quand tout lê monde a tort, tout lê monde a raison...(Quando todos eram, todos acertam...) - Também, no mesmo período, foi cogitado a possibilidade de adotar-se outro nome para Boa Vista (Uilã, Parima ou outra designação ligada a cultura regional). Porém, o Deputado Valério Magalhães foi contrário a mudança em respeito ao seu bisavô e fundador da fazenda Boa Vista, o qual, Ihe conferiu a respectiva denominação. 
pois é uma área alta que não inunda, assim como o canal do rio é mais profundo e favorece a navegação, diferentemente da margem esquerda que é inundada no período chuvoso de abril a setembro (Figura 2).

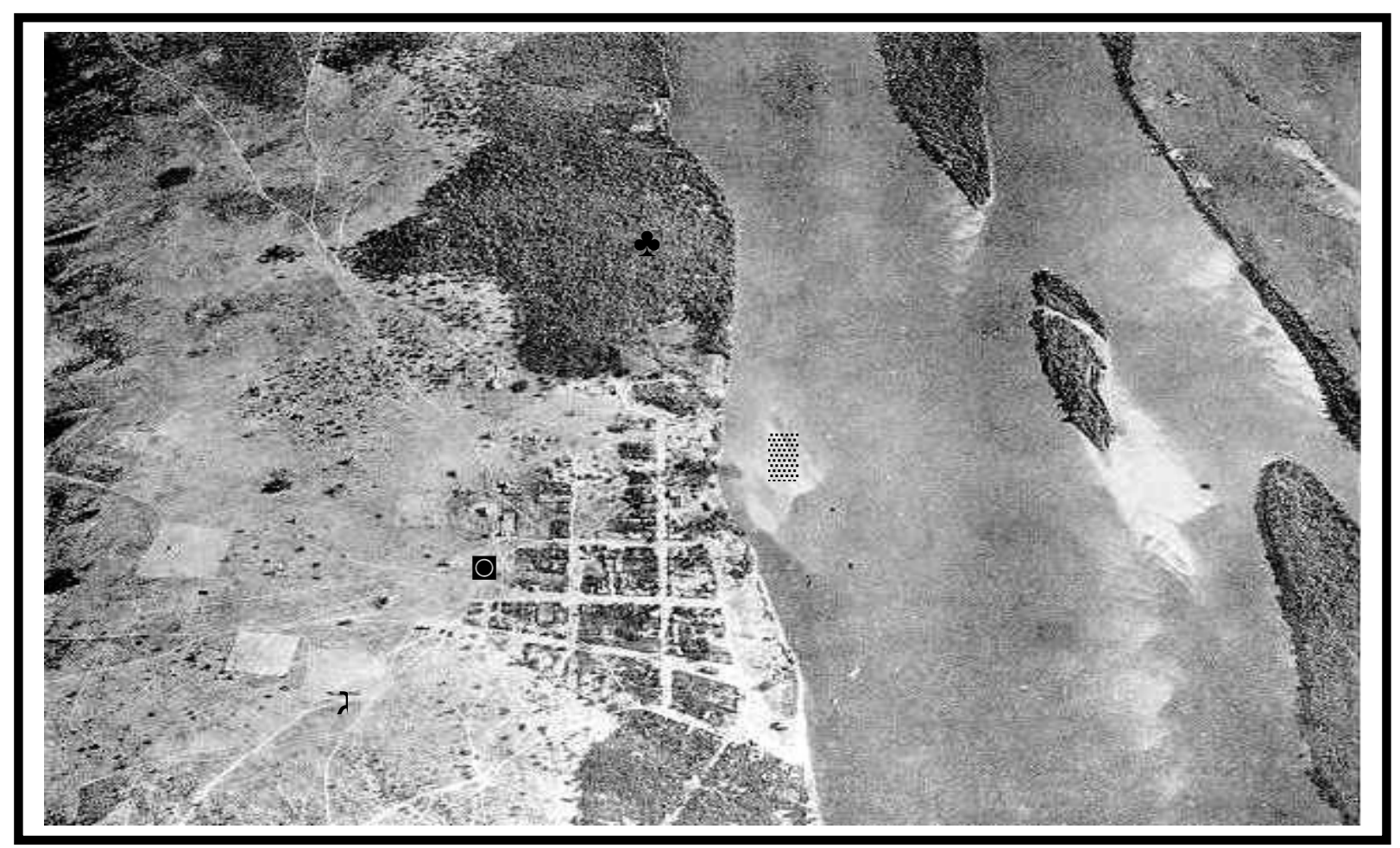

Figura 2: Situação de Boa Vista \} 1 9 2 4

Legenda: ם Boa Vista \ Rio Branco \ Estradas $\backslash$ Mata Ciliar

Foto: Acervo de Hamilton Rice

A cidade estar localizada numa superfície marginal ao grande rio, de onde partem várias estradas abertas ao longo do lavrado que seguem direções variadas, como evidencia a Figura 2, em busca das sedes das fazendas (GUERRA, 1957, p. 137). Era natural que se procurasse situá-la em posição de conexão com esquemas eficazes de comunicação, e esta era garantida, de preferência, por meio das vias fluviais, fosse para o escoamento dos produtos que constituíam a base econômica da cidade na época, fosse para a obtenção de produtos manufaturados.

Outro aspecto que contribuiu para a localização da cidade foi a existência de caminhos - estabelecidos, em geral, com base nas velhas trilhas indígenas, que garantiam as comunicações com o interior, vencendo os principais obstáculos geográficos e estimulando o crescimento da cidade. 
Em relação ao sítio, Reis Filho (1968, p. 124) avalia que é o local sobre o qual está assentada uma aglomeração urbana. Vários são os aspectos a considerar na caracterização do sítio das povoações, tais como: natureza do solo, relevo, fontes de água para o consumo, cursos ou massas de água entre outros. Beaujeu - Garnier (1997, p. 76) acrescenta que o sítio, freqüentemente, não tem mais do que um valor histórico. O desenvolvimento da cidade faz-se a partir dele; a cidade envolve-o, transforma-o e, por vezes, abandona-o.

No caso de Boa Vista, o sítio está situado sobre uma topografia plana e sensivelmente uniforme. Em sua superfície existem várias depressões cheias de água (GUERRA, 1957, p. 137).

No leito do rio observam-se várias ilhas aluviais, onde a vegetação arbórea cobre todo o solo. Nas margens do rio Branco, especialmente na esquerda, em grandes trechos vê-se o aparecimento da vegetação do tipo campestre (GUERRA, 1957).

Em sua pesquisa sobre o vale do rio Branco, Guerra (1957) mostra que a topografia da zona urbana da cidade pode ser definida como sendo uma grande superfície plana que apresenta alguns sulcos, os quais foram escavados por igarapés de pouca importância (Figura 3). 


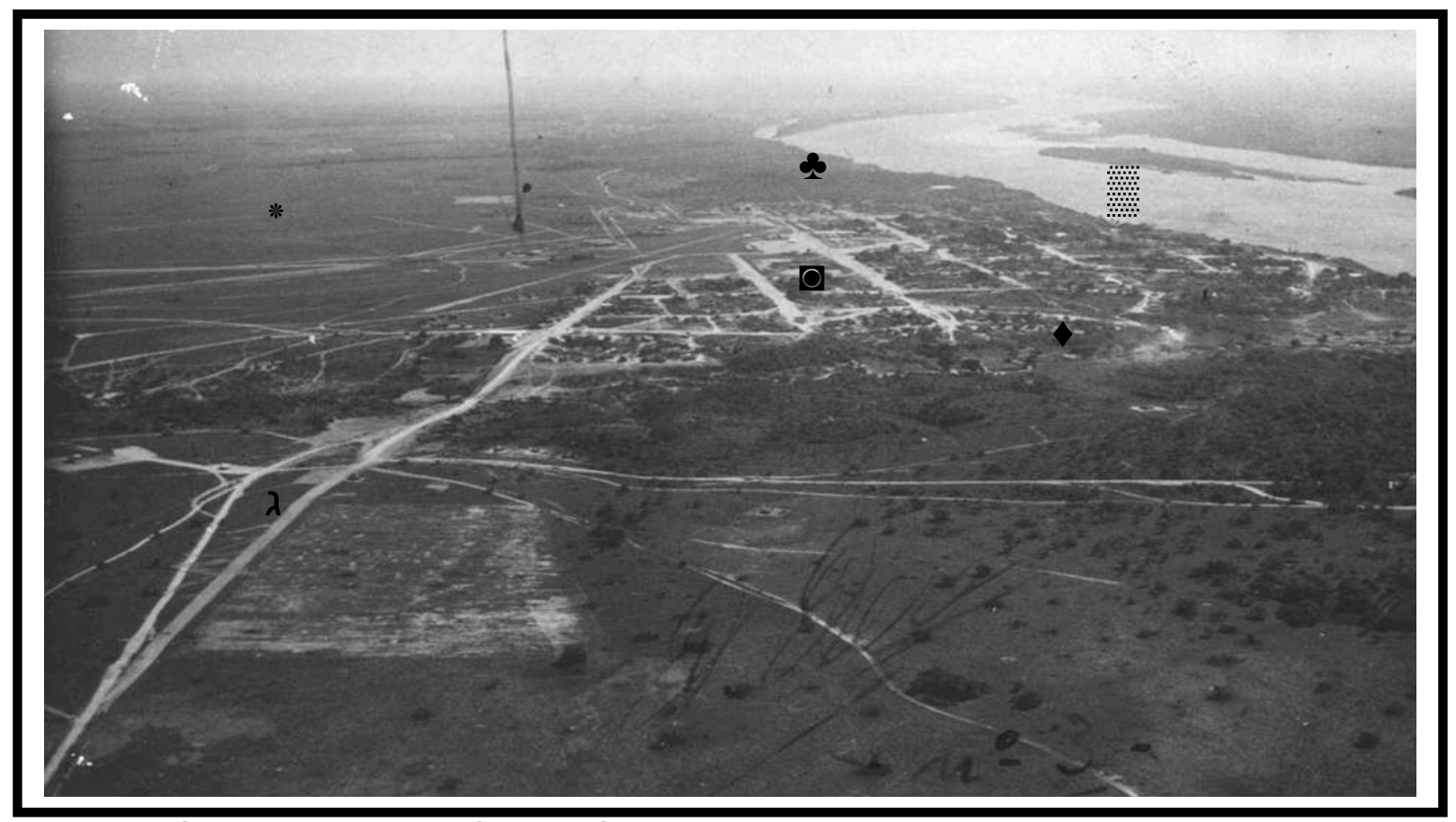

Figura 3: Sítio de Boa Vista \Déc. 40. Séc. XX

Legenda: o Boa Vista \" Rio Branco \גEstradas $\$ Sulcos (Igarapés)।*Lavradol Mata Ciliar Foto: Acervo de Darcy Romero Derenusson

Estudos do Centro pelo Direito à Moradia Contra Despejos - COHRE (2005 e 2006, p. 39), Organização não Governamental Internacional e Independente, com sede em GÊnebra - Suíça, reafirma as palavras de Guerra (1957) ao relatar que:

A cidade de Boa Vista está situada sobre os campos naturais da bacia do Alto Rio Branco. O território apresenta o predomínio de solos arenosos sobre rochas e cerrados e campos (lavrados) com fundos aluviais de vales de rios e igarapés. O sistema ecológico predominante é a Savana (gramínea lenhosa) que apresenta uma fisionomia campestre com arvores isoladas de pequenos porte que costumam se adensar nas proximidades dos cursos d'água, ladeados por filas de palmeiras e pequenas depressões lagunares temporárias, elementos que compõem uma densa rede de drenagem formada pelo rio Branco e seus afluentes, e por igarapés e lagoas de regime permanente (perÊne).

Para o COHRE (2005\2006), é sobre esse sistema natural que se assenta a cidade de Boa Vista. Sistema, esse, que não foi preservado no processo de uso e ocupação do solo urbano da cidade. Percebe-se que a apropriação da terra urbana ao longo de sua formação sócioespacial deu-se de forma desordenada, ou seja, resultaram de edificações em áreas inundáveis, aterros das áreas de lagoas, lançamento de esgoto in natura entre outros; sem a preocupação com o funcionamento dos sistemas de drenagem, o que acarretou e acarreta danos, desaparecimento ou degradação de igarapés e lagoas ao longo de sua produção sócioespacial. 
O Engenheiro Alfredo Ernesto Jacques Ourique, em seu relatório sobre o vale do rio Branco, elaborado em 1906 sob a ordem do então Governado do Estado do Amazonas, Dr. Antonio Constantino Nery, que tinha como objetivo tornar conhecida essa rica região, descreve a cidade da seguinte forma:

Do seu cômodo porto (Figura 4), cortado pela natureza em curva regular no barranco da margem, sobe-se por sua suave ladeira até o chapadão, em pleno campo, onde esta a vila. Seu conjunto apresenta perspectivas em geral encantadoras e, de alguns pontos de vista, realmente belas. Possuem boas casas, algumas de alvenaria e uma capela edificada singelamente, mas com relativa elegância. Pode-se considerar Boa Vista como o centro mais importante de todo o movimento comercial e agrícola do alto rio Branco. (OURIQUE, 1906, p. 13).

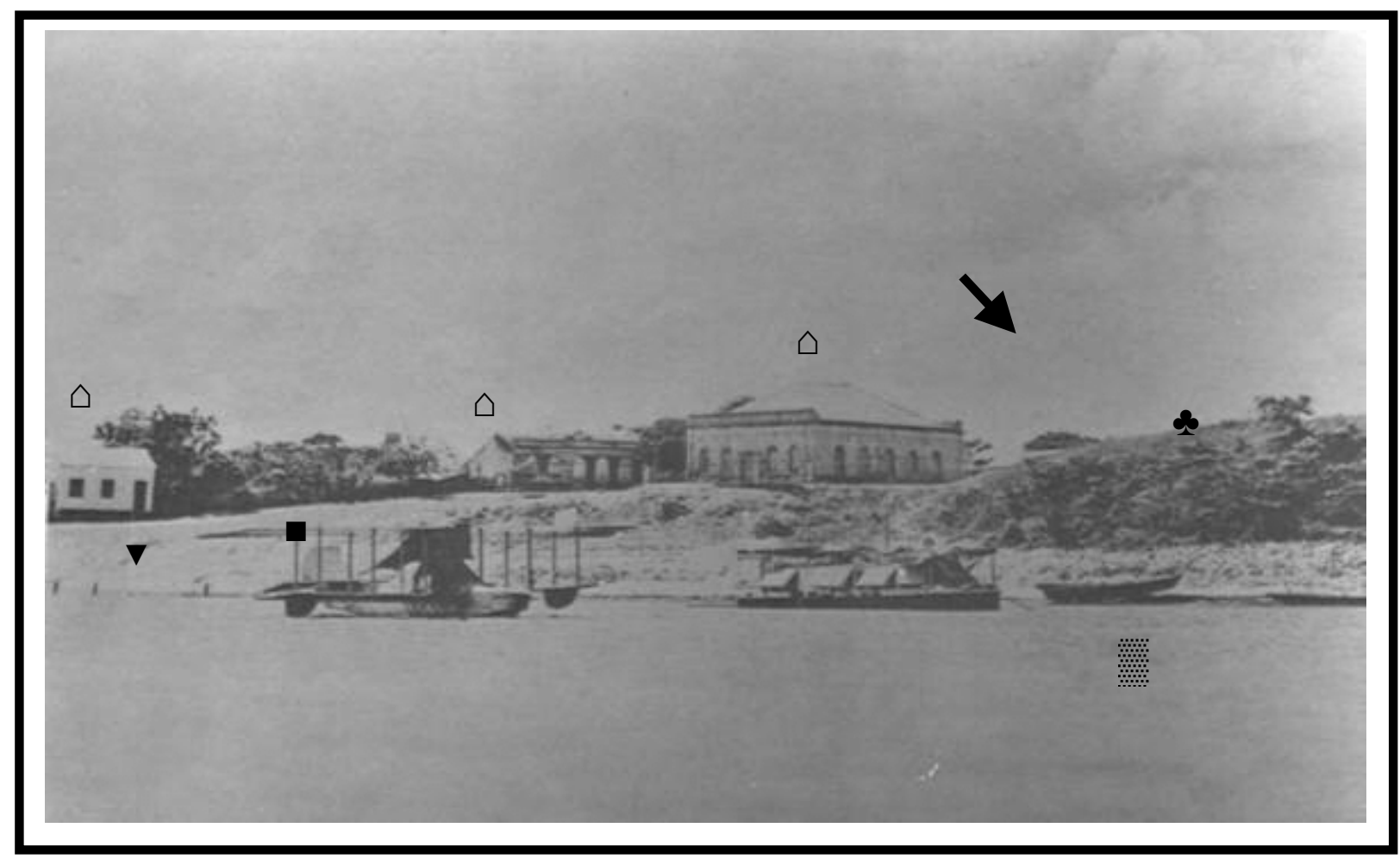

Figura 4: Porto de Boa Vista do Rio Branco \Déc. 20 - Séc.XX Legenda: — Porto $\backslash \nabla$ Baixada $\backslash \triangle$ Edificações $\backslash$ Mata Ciliar $\backslash$ Rio Branco $\backslash \backslash$ Vila Foto: Acervo de Waldir Paixão

Comungando com o COHRE (2005-2006), Guerra (1957) e Ourique (1906), Diniz \& Amorim Filho (2005, p. 27) diz que Boa Vista está situada à margem direita do rio Branco, sobre terrenos de altitude uniforme, localizada entre as terras baixas da Floresta Amazônica e as elevações do sistema das Guianas. Para os pesquisadores, a cidade apresenta uma altitude média de $85 \mathrm{~m}$, com clima quente úmido e duas estações climáticas definidas - chuvosa e seca, com uma cobertura vegetal predominantemente dos campos limpos. 
$\mathrm{Na}$ análise de Guerra (1957, p. 138), o único fato que possivelmente tenha levado a esta escolha de estabelecer o sítio urbano na margem direita, foi a existência da baixada junto à margem do rio, facilitando as primeiras edificações (porto, armazéns, residências entre outras), face às terras altas da cidade, que posteriormente foram ocupadas (Figura 5).

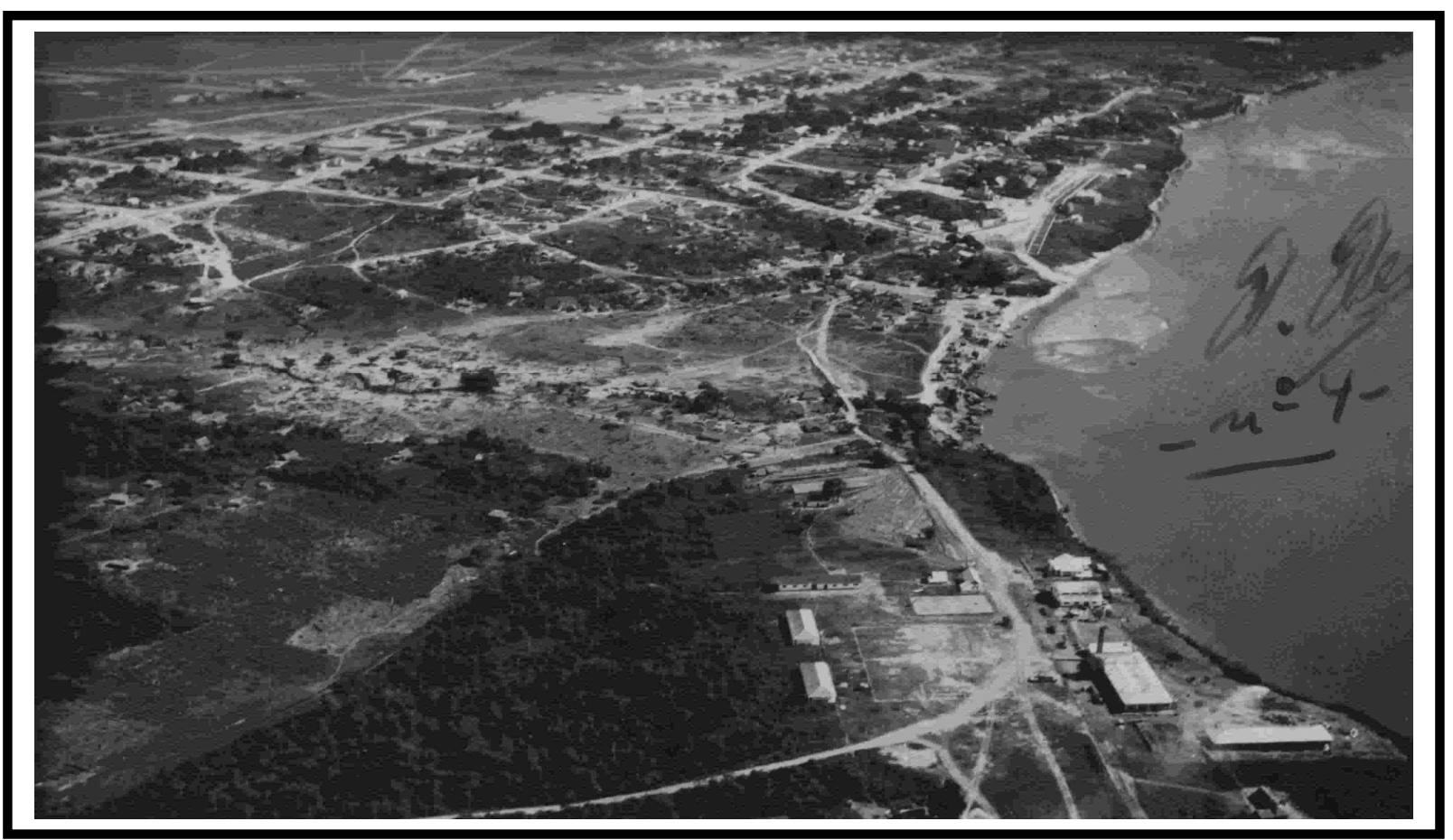

Figura 5: Cidade de Boa Vista $\backslash$ Déc. 40 - Séc. XX

Foto: Acervo de Darcy Romero Derenusson

A cidade cresceu à margem direita do rio Branco, ocupando parte da planície de inundação e interiorizando-se para o setor Oeste da cidade, onde o terreno é plano e com pouca declividade.

Considerando-se à geologia do sítio, Costa $(2007)^{11}$ acredita ter sido sobre os terrenos lateríticos mais elevados da margem direita do rio Branco que surgiu o núcleo embrionário da cidade de Boa Vista. Esses embriões das primitivas ocupações destacavam-se sobre um relevo de colinas suavemente onduladas, sustentadas por lateritos desenvolvidos sobre os terrenos pré-cambrianos, mesozóicos e cenozóicos (gnaisses - provavelmente da Suíte Metamórfica Rio Urubu), rochas vulcânicas, Complexo Apoteri e sedimentos da Formação Boa Vista.

${ }^{11}$ Essa informação foi colhida por meio de entrevista, realizada no dia 2810612007, com o Doutor José Augusto Vieira Costa, Professor Doutor em Geologia do Instituto de Geociências - Departamento de Geologia da Universidade Federal de Roraima. 


\section{b) $O$ tecido urbano}

O tecido urbano, na acepção de Reis Filho (2006:13)

[...] refere-se à escala na qual se definem as relações físicas e jurídicas entre espaços públicos e espaços privados, em que se definem as ruas e praças, as quadras e lotes, a propriedade (ou posse) do espaço urbano, sua produção material, bem como sua apropriação, uso ou transformação. Essas relações se definem nos projetos e nas obras (produção material do espaço).

No que tange aos fatores considerados para o surgimento do núcleo embrionário de Boa Vista na margem direita do rio Branco, as observações de Guerra (1957) e Ourique (1906) apontam os fatores naturais como tendo sido primordiais, uma vez que a escolha dos sítios pelos povoadores tinha em vista os aspectos geográficos - relevo plano que favorecesse o assentamento urbano próximo ao rio, vegetação e solo apropriado para a agropecuária entre outros, buscando, em princípio, a localização que oferecesse o máximo de comodidade e segurança para o pequeno agrupamento, em geral modesto, em sua origem. Haja vista as cheias do rio Branco em seus longos invernos.

A iconografia da época, segundo Rice (1978, p. 63), mostra que o núcleo urbano primitivo apresentava um traçado ortogonal, com ruas se cruzando em ângulos retos, talvez pelo fato de simplificar a circulação e facilitar o processo de loteamento dos terrenos. Nota-se, também, uma conformidade com o curso do rio, dada sua importância como instrumento de navegabilidade (Figura 6). 


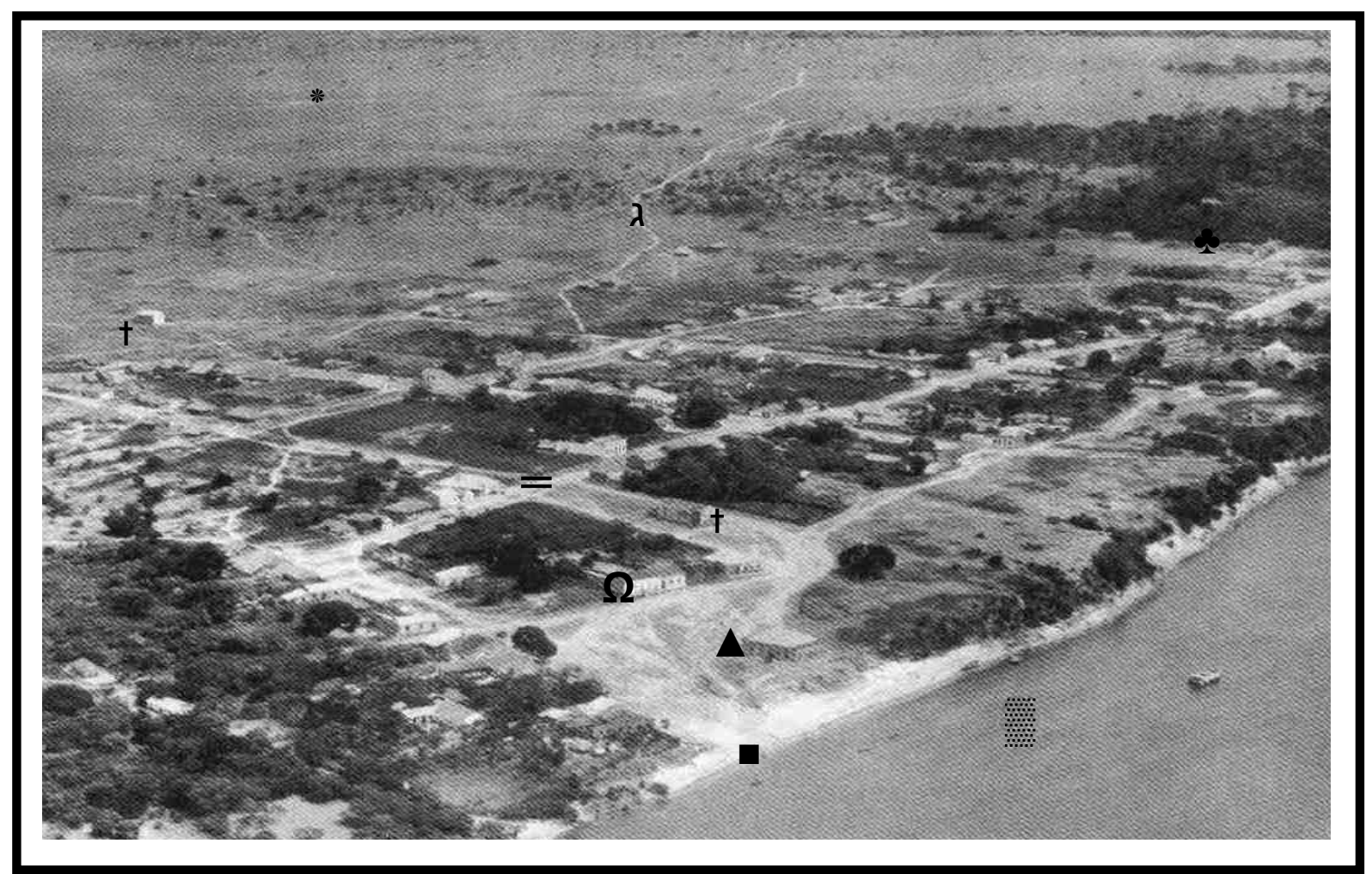

Figura 6: Boa Vista \} 1 9 2 4

Legenda: † Igrejas $\backslash \Omega$ Antiga sede da fazenda $\backslash \boldsymbol{\Delta}$ Intendência $\backslash$ Rio Branco $\backslash$ —Porto $\backslash$ A Estradas $\backslash$ * Lavrado $\backslash$ Mata Ciliar $\backslash=$ Ruas

Foto: Acervo de Pavani \& Moura

A matriz, a sede da Intendência da Vila de Boa Vista do Rio Branco e a residência da antiga sede da fazenda Boa Vista, entre outros, eram, em sua essência, o conjunto focal da vida e da paisagem da vila e, posteriormente, da cidade constituída (Figura 7; 8 e 9). 


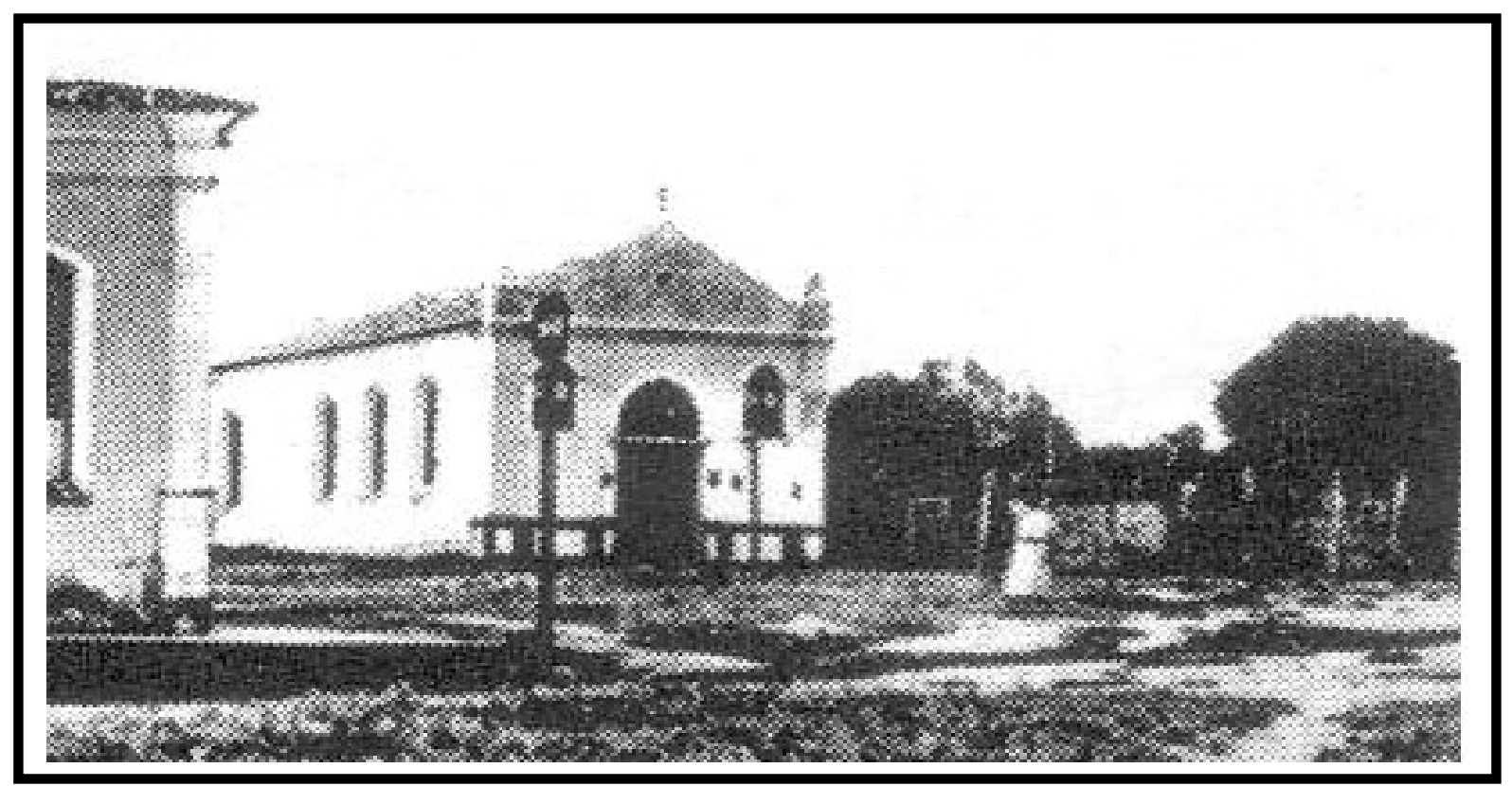

Figura 7: Igreja Matriz de Boa Vista \} 1 9 0 5

Foto: Acervo de Tiago Orihuela

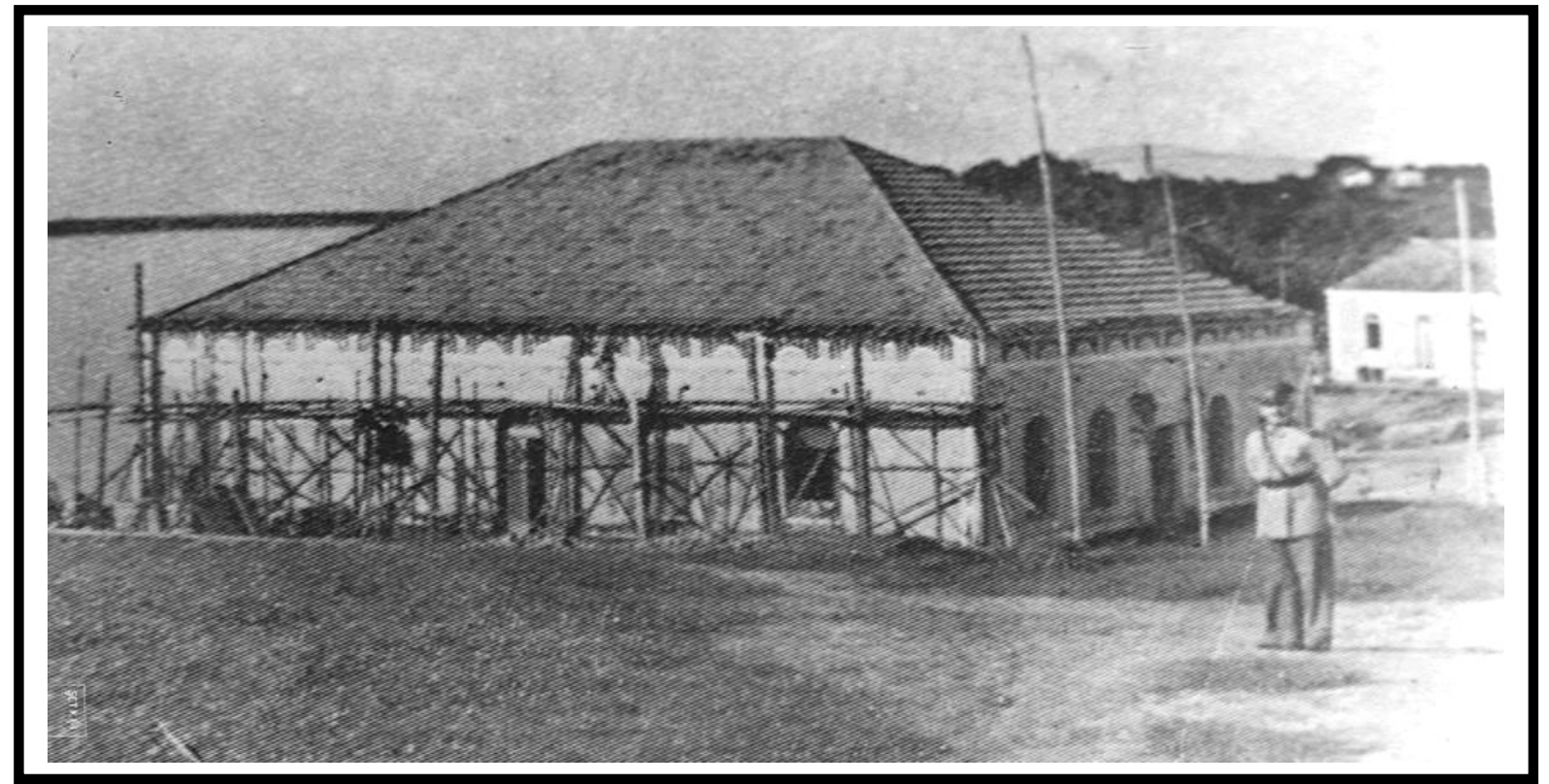

Figura 8: Sede da Intendência \} \backslash 1 9 2 5

Foto: Acervo de Waldir Paixão 


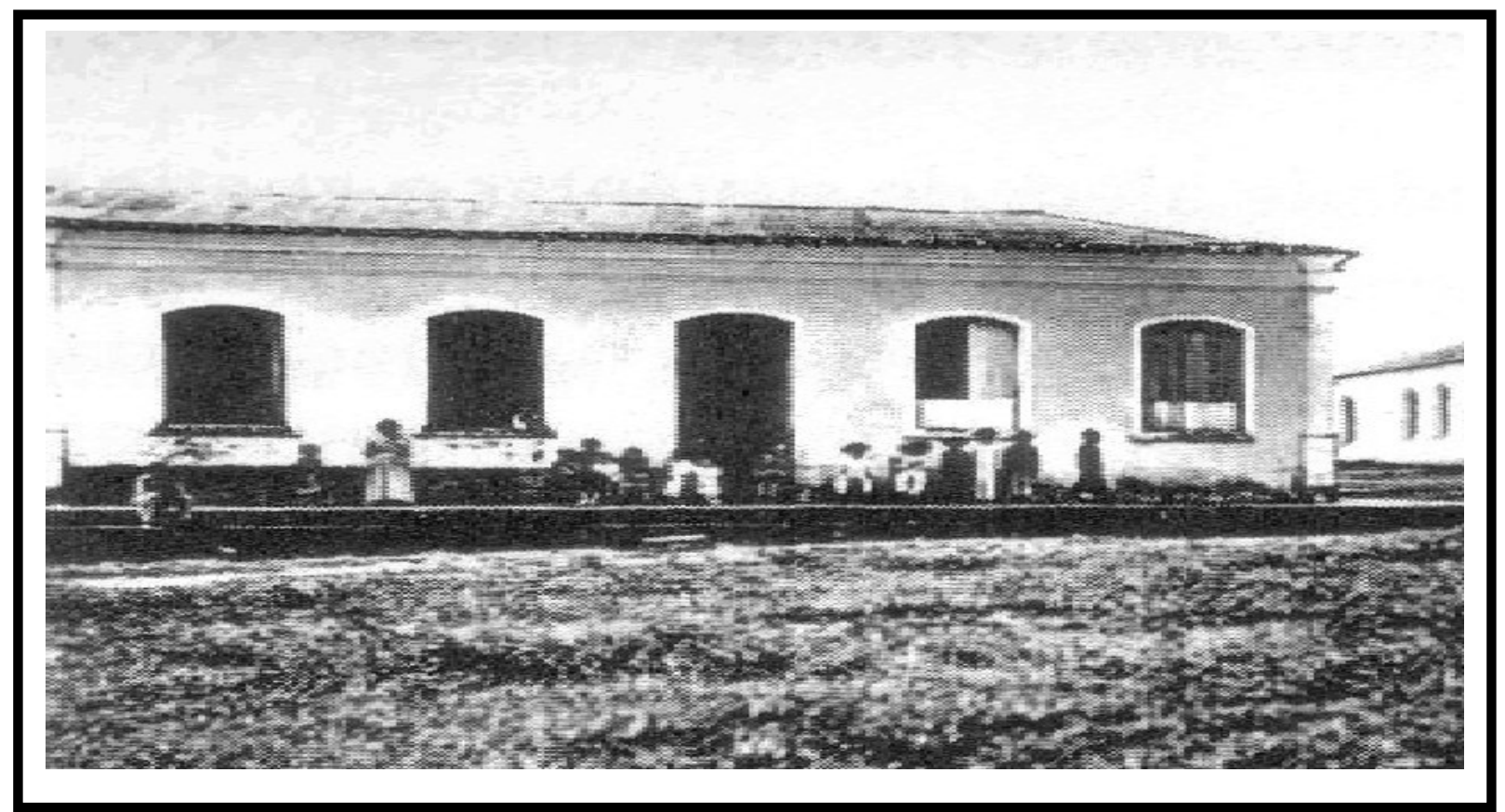

Figura 9: Sede da Antiga Fazenda Boa Vista \} 1 9 0 5

Foto: Acervo de Tiago Orihuela

Na época, conforme Oliveira (1929, p. 25), a cidade apresentava ruas largas e retas, sem iluminação e sem arborização. Possui um comércio ativo que abastecia toda a região e, até mesmo, as fronteiras da Venezuela e da Guiana.

$\mathrm{Na}$ prática, as linhas de demarcação urbana - uso e ocupação, não costumavam ser bem definidas. A cidade manteve esses traços ao se desenvolver, aumentando a sua população, seu número de lares, de vendas e o oferecimento de serviços em função das atividades desenvolvidas no período.

Em meados do ano de 1920, Boa Vista tinha aspecto de vila solitária e isolada da Capital do Amazonas e do resto do País. Embora pagasse impostos sobre o gado que exportava, não os conhecia nem os desfrutava, já que eram direcionados à Capital do Amazonas. "Tudo o que lhe restava era a má orientação tributária" (SANTOS, 2004, p. 82).

Todavia, segundo Santos (2004, p. 82), Boa Vista

[...] já apresentava nessa época, casas bem construídas, com misturas de pedra e cal, cobertas de telhas, bem cuidadas e pintadas com cores alegres e uma bela capela que causavam boa impressão a qualquer visitante. Tinha ao todo quarenta e nove residências, entre casas e barracos, que eram dispostas separadas umas das outras, por certa distancia, dando uma impressão de espaço ocupado bem maior do que o real. A Vila já se destacava pela largura das suas ruas, semelhantes a avenidas das grandes cidades. E, apesar de não possuir calçamento, as ruas eram mantidas limpas e bem conservadas. 
Na série monográfica, Território Federal de Roraima: Município de Boa Vista (1987, p. 48) encontra-se uma visão sócioespacial da cidade de Boa Vista, feita por Joaquim Gondim quando de sua visita em 1922 e publicado no Boletim №. 6 da Diocese de Roraima. No comentário, Joaquim Gondim, expõe:

Não é grande o movimento comercial e industrial da localidade, mas está de acordo com as necessidades da população, que é de seiscentas e vinte e uma almas, segundo o último recenseamento. Boa Vista conta com quartorze mercearias, um botequim, uma pharmácia, duas oficinas de ferreiro, uma carpintaria e funilaria, uma barbearia e o importante estabelecimento "canto da fortuna", do Senhor João Secundino lopes, que explora, conjuntamente, o comércio de fazendas, miudezas e estivas, além da indústria da panificação e do fabrico de sabão, servindo-se no preparo de seus produtos, de machinismos especiais. O seu estabelecimento, o único que possui bombeamento d'água, achava-se provido de instalações elétrica.

No povoado e nas fazendas andava-se a pé, de carroça puxada por boi e a cavalo, não existindo nenhum outro tipo de transporte de comunicação terrestre (Figura 10 e 11).

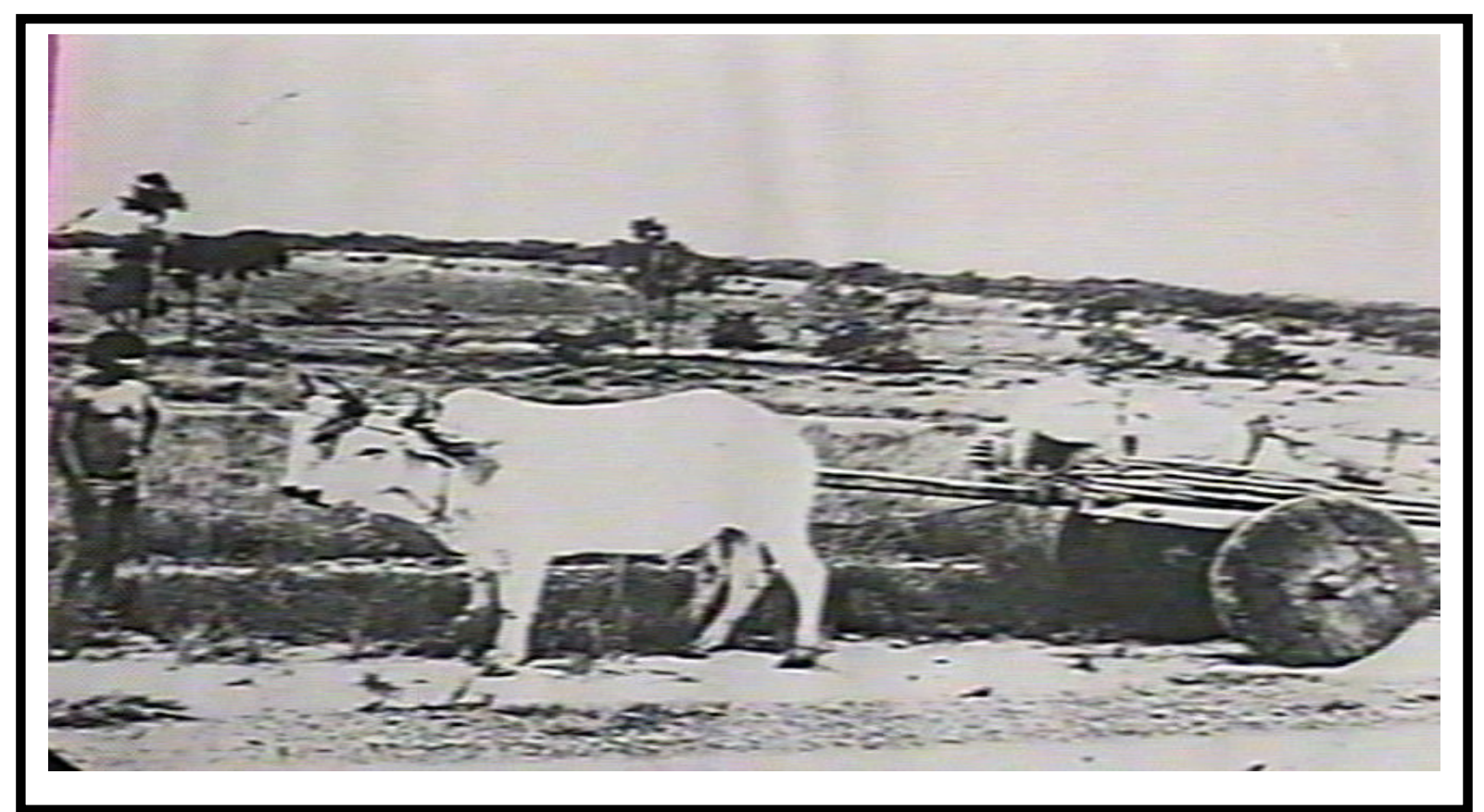

Figura 10: Meio de Transporte (carro de boi) \ Déc. 20 - Séc.XX

Foto: Acervo de Tiago Orihuela 


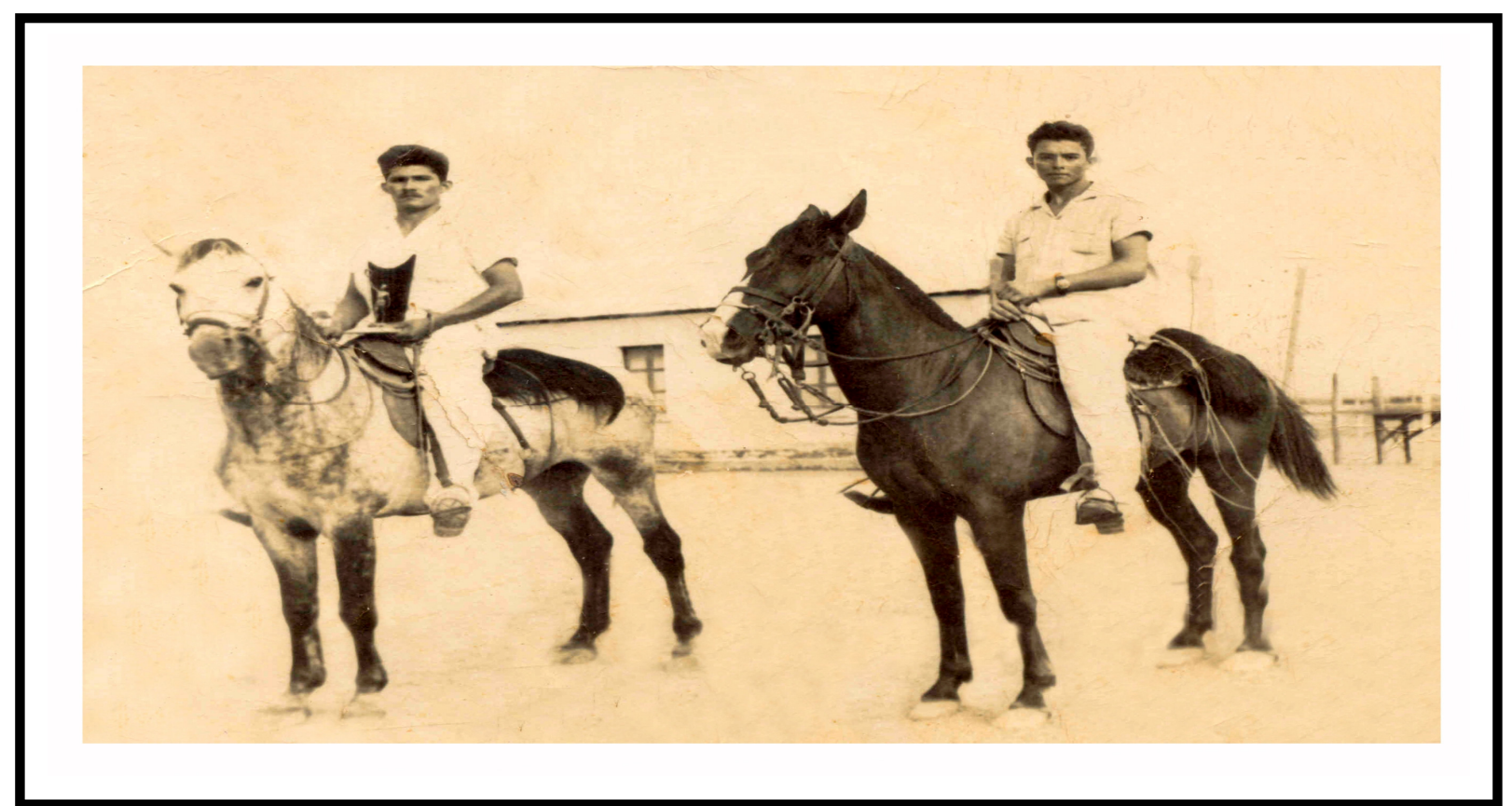

Figura 11: Meio de Transporte (Cavalo)

Foto: Acervo de Tiago Orihuela

Rice (1978, p. 25) esclarece que Boa Vista, em 1924, era o único agrupamento próximo ao rio Branco que tem a honra de ser chamado vila. Em seu território havia 164 casas, algumas construídas com tijolo (igreja, intendência, casas e armazém) e a maioria feita de reboco e pau-a-pique. Abrigava 1200 pessoas, entre portugueses, brasileiros, mestiços, índios e alguns negros vindos das Índias Ocidentais pela Guiana Inglesa.

Lentamente a sede do município apresentava forma, porém a ausência de políticas públicas por parte do governo do Estado do Amazonas contribuiu significantemente para que as residências e comércio se localizassem próximo à margem direita do rio Branco. Uma vez, que o meio de escoar a produção para os outros estados, em sua maioria, se dava exclusivamente pelo rio Branco. 
D. Pedro Eggerath, quando de sua visita à região do alto rio Branco, na década de 1920, fez o seguinte comentário:

[...] O aspecto das casas, construídas em parte de pedra e cal, cobertas de telhas e dispostas ao longo de ruas largas, é difícil de descrever, muito embora esteja a sede deste enorme município representado apenas por 200 edificações, entre casas e barracas, distantes umas das outras, o que explica a razão das muitas ruas e o fato de parecer Boa Vista, de longe, muito maior do que realmente é. A sua população que se pode estimar em 1300 habitantes, compõem-se na sua maioria de famílias de fazendeiros do Rio Branco. Perto do lugar de desembarque, vê-se em uma das praças a Igreja de N.S. do Carmo, de construção antiga e, até sendo concertada condignamente. $\mathrm{O}$ edifico da municipalidade fica logo em frente ao porto; é de feitio simples, mas sólido. As demais edificações são em sua maioria casas de famílias, afora alguns negócios e barracas (EGGERATH, 1924, p. 12).

Na percepção de Macaggi (1976, Apud Silva, 2007, p. 200), Boa Vista era um

(...) vilarejo até 1926, pequenina e triste, possuía na ocasião regular número de habitantes. Muito espalhada, com poucas casas de alvenaria e inúmeras de taipa, cobertas de palha de buriti ou inajá. Sem árvores, sem praças e sem flores. Prédios velhos e feios. Quintais abertos e abandonados, sem uma horta ou jardinzinho. Só um bangalô, à distancia, embelezando a paisagem. Nenhum grupo escolar, sendo raras suas escolas, regidas por professores primários. Sem cáis e as margens do rio terríveis para a atracação das embarcações.

O Senhor Said Samou Salomão, influente comerciante local, quando de sua chegada em Boa Vista no ano de 1929, retrata em entrevista à Camurça Neto (1996, p. 11) sobre a realidade sócioespacial da cidade, relata que a população local, ao contrário de Rice e Eggerath, era estimada em 850 habitantes, as construções estavam situadas em sua maioria nas margens do rio Branco, dada sua importância como via de navegabilidade na época. A infra-estrutura em termos de serviços básicos era inexistente; não havia água encanada e nem energia elétrica. Todavia, havia um hospital de Nossa Senhora de Fátima sob a administração das Madres Beneditinas, que, apesar de não ter um médico permanente, possuía três enfermeiras e um dentista, era tudo que existia no setor de saúde. Em Boa Vista devem existir apenas 15 casas de comércio.

Em Farrar \& Rinehart (1934, Apud Silva, 2007, p. 202), o novelista Waugh diz que a mancha urbana do núcleo compreendia inicialmente a margem direita do rio Branco, em sua visão a paisagem construída era "uma confusão de casas em ruínas", quando ali chegou no ano de 1934, a rua central de Boa Vista tinha o seguinte aspecto, "(...)era larga, com piso de barro ressecado e desnivelado, com 
largas fendas por toda parte e sulcado por várias sarjetas secas. As casas caiadas, cobertas de telhas, de um só andar, eram enfileiradas de um lado e do outro da rua".

Waugh descreve, ainda, que:

Havia a rua central pela qual nós chegamos - Rua Bento Brasil - duas estradas paralelas menos importantes e mais quatro outras ruas que a cortavam em ângulo reto. Em todas as direções depois de uns 400 metros, as estradas sumiam aos poucos, se transformando em vagarosos caminhos (FARRAR \& RINEHART. 1934, Apud SILVA, 2007, p. 202).

Na perspectiva de Silva (2007), essa paisagem em construção e isolada era conhecida a partir da percepção destes exploradores e viajantes que ali passavam e Ihe descreviam "[...] Era o urbano na infinita Amazônia em transição para o "lavrado", o único depois de Manaus para quem buscava o Norte em direção à Venezuela e à Guiana ou o primeiro para quem descia desses países".

Essa configuração espacial permaneceu até 1944. Como relata o Governado Êne Garcez ao chegar a Boa Vista. Na cidade só havia três ruas paralelas ao rio Branco. Era a rua da prelazia, a outra seguinte (Sebastião Diniz) e a última, que só tinha um lado (Getúlio Vargas) ${ }^{12}$ (Mapa 4).

\footnotetext{
${ }^{12}$ Maiores informações consultar relato verbal do ex-governador Capitão Êne Garcez dos Reis em FREITAS, Aimberê. A História Política e Administrativa de Roraima de 1943 a 1985. Manaus: Editora Umberto Calderaro Ltda. 1993, p. 62-63.
} 


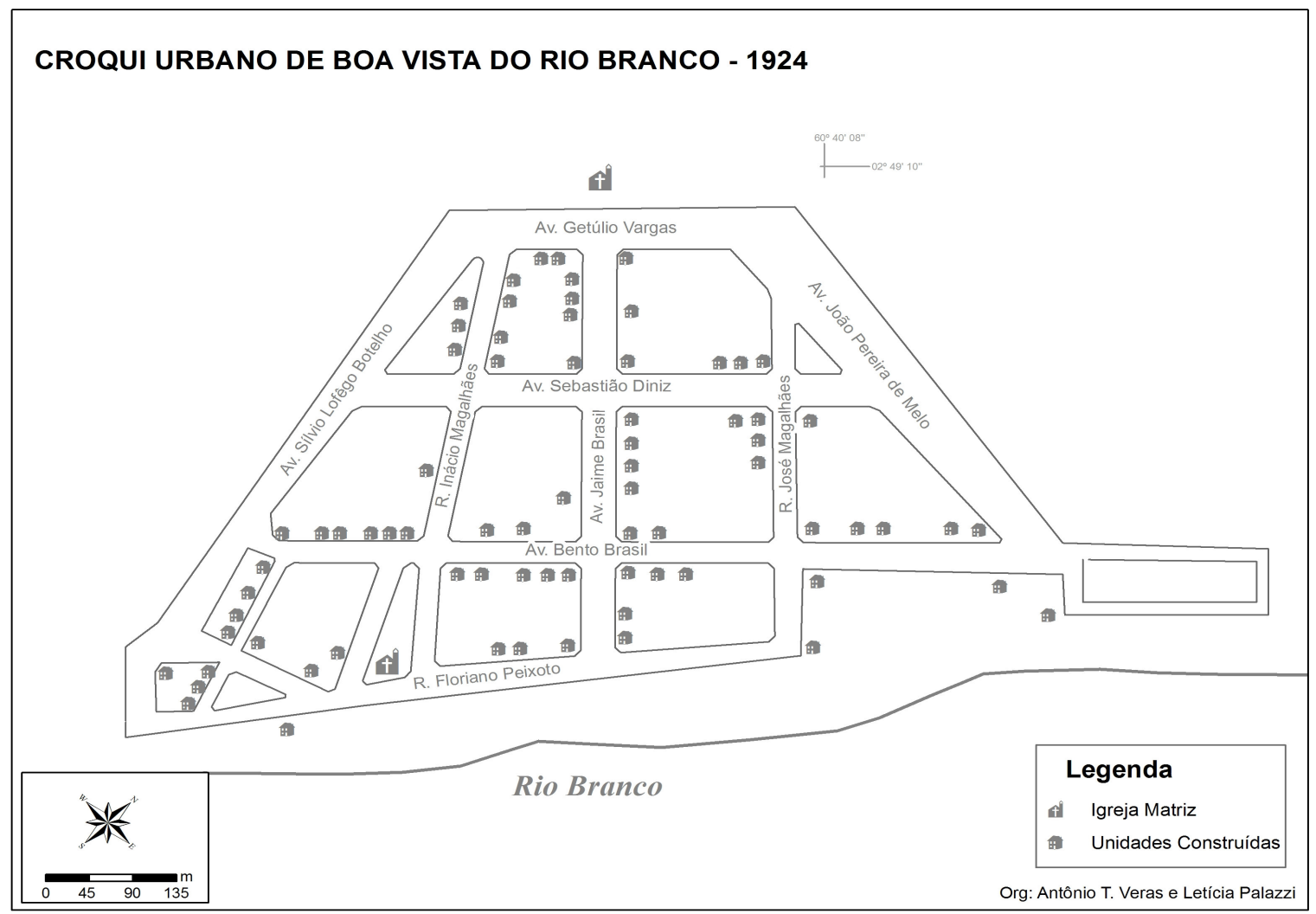

Mapa 4: Croqui urbano de Boa Vista $\backslash 1924$

Fonte: Série Monográfica de Boa Vistal1987.

Organização: Antonio T.R.Veras e Letícia Palazzi

Para Barros (1995, p. 51), a estrutura urbana herdada é representada por lotes estreitos de casas conjugadas de ambos os lados, ao velho estilo lusitano, acomodando-se ás oscilações do relevo ribeirinho (Figura 12). 


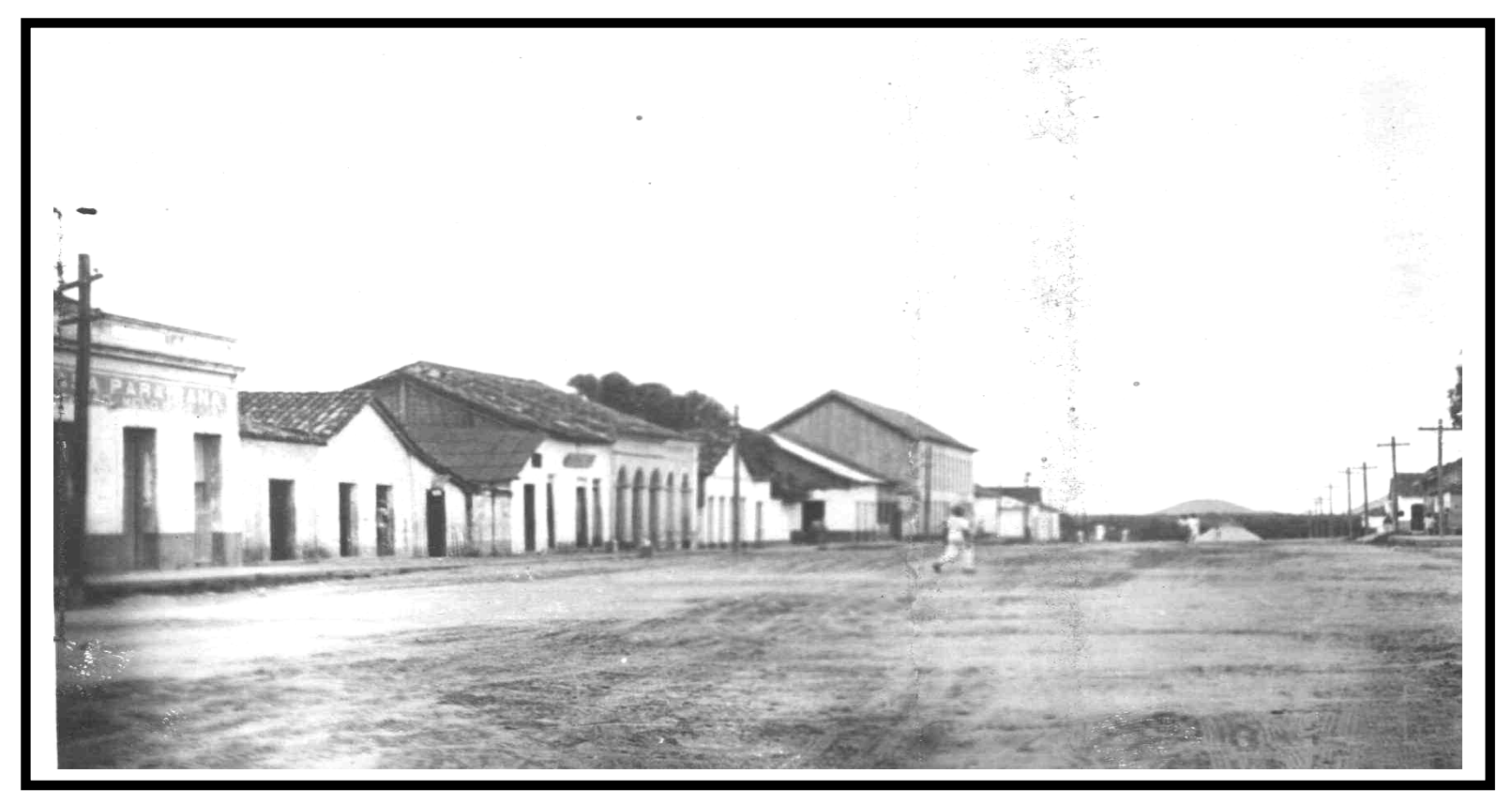

Figura 12: Residências antigas de Boa Vista (Av. Jaime Brasil)\ Déc.50 - Séc. XX Foto: Acervo de Darcy Romero Derenusson

Importante destacar que as análises, observações e descrições dos pesquisadores e viajantes - supracitados-, sobre a configuração sócioespacial de Boa Vista, apontam para diferentes acepções sobre o espaço urbano de Boa Vista, seja em relação à população, ao comércio, a habitação e à urbanização, entre outros. O que nos leva a crer que o período compreendido entre os anos de $1890 \mathrm{e}$ meados de 1940, referente aos dados quantitativos e qualitativos dos sistemas de objetos e ações, em sua maioria,eram expressos a partir de observações empíricas dos que ali passavam, moravam, exploravam e governavam.

No entanto, no dia $1^{\circ}$ de setembro de 1940 , foi realizado o recenseamento geral da República, quando se teve um diagnóstico censitário coerente com a realidade local. Foram recenseados 10509 habitantes, sendo que 5248 estavam residindo no distrito sede de Boa Vista e 610 e 4 651, respectivamente, em Caracaraí e Murupu (IBGE, 1951, p. 8).

Segundo o IBGE (1951), destes 10509 recenseados, 1398 habitavam o perímetro urbano e suburbano de Boa Vista, e 9111 residiam na zona rural.

Em relação ao registro predial e domiciliário foi contabilizado a existência de 1 639 unidades, sendo 211 no perímetro urbano, 48 no suburbano e 1380 na zona rural. No que se refere ao material de construção dessas unidades, o recenseamento revelou que 153 eram de alvenaria - sendo que 111 situadas no 
perímetro urbano e 24 no suburbano -, 1453 de madeira - 1331 localizadas na zona rural -, e 33 de tipo não especificado. Apenas 61 possuíam instalação elétrica e apenas uma possuía água encanada e banheiro, não foram encontradas em nenhuma delas instalações sanitárias adequadas (IBGE, 1951, p. 9).

Esses dados revelaram o descaso que o governo do Estado do Amazonas tinha com a região do vale do rio Branco, em particular com o município de Boa Vista. Tal realidade exigia do Governo Federal medidas urgentes para solucionar as condições rudimentares de vida dos seus habitantes e desenvolver e proteger essa região fronteiriça.

Diante dos fatos, os moradores locais, fazendeiros, comerciantes e indígenas aspiravam a alcançar a autonomia política e administrativa em relação ao Estado do Amazonas. Essa conquista colocaria Boa Vista como unidade autônoma e com área territorial definida. Tal anseio só viria acontecer em 1943 com a criação do Território Federal do Rio Branco.

Desta maneira, falar sobre a produção do espaço urbano de Boa Vista, "é falar desse espaço como componente da produção social em geral, que tem uma lógica, uma dinâmica que é própria dessa produção social, de um modo de produção da sociedade" (CAVALCANTI, 2001, p. 15).

Um exemplo dessa produção social pode ser expressa por meio da arquitetura e engenharia da época, que em decorrência da ausência de investimentos governamentais e isolamento do resto do país, utilizavam como material de construção madeira, barro e palha de buriti típica da região. Também, tinham influência da arte de construir dos indígenas e dos nordestinos que moravam na cidade.

Intensificando esta idéia, Pavani \& Moura (2007, p. 25) diz que, por ser uma região descapitalizada e isolada, foi necessário usar, nas primeiras edificações, o material existente na localidade - barro, madeira, palha de buriti. Para os autores, as casas de taipa das fazendas e das vilas com suas coberturas de palha de buriti são características marcantes aproveitadas até hoje (Figura 13). 


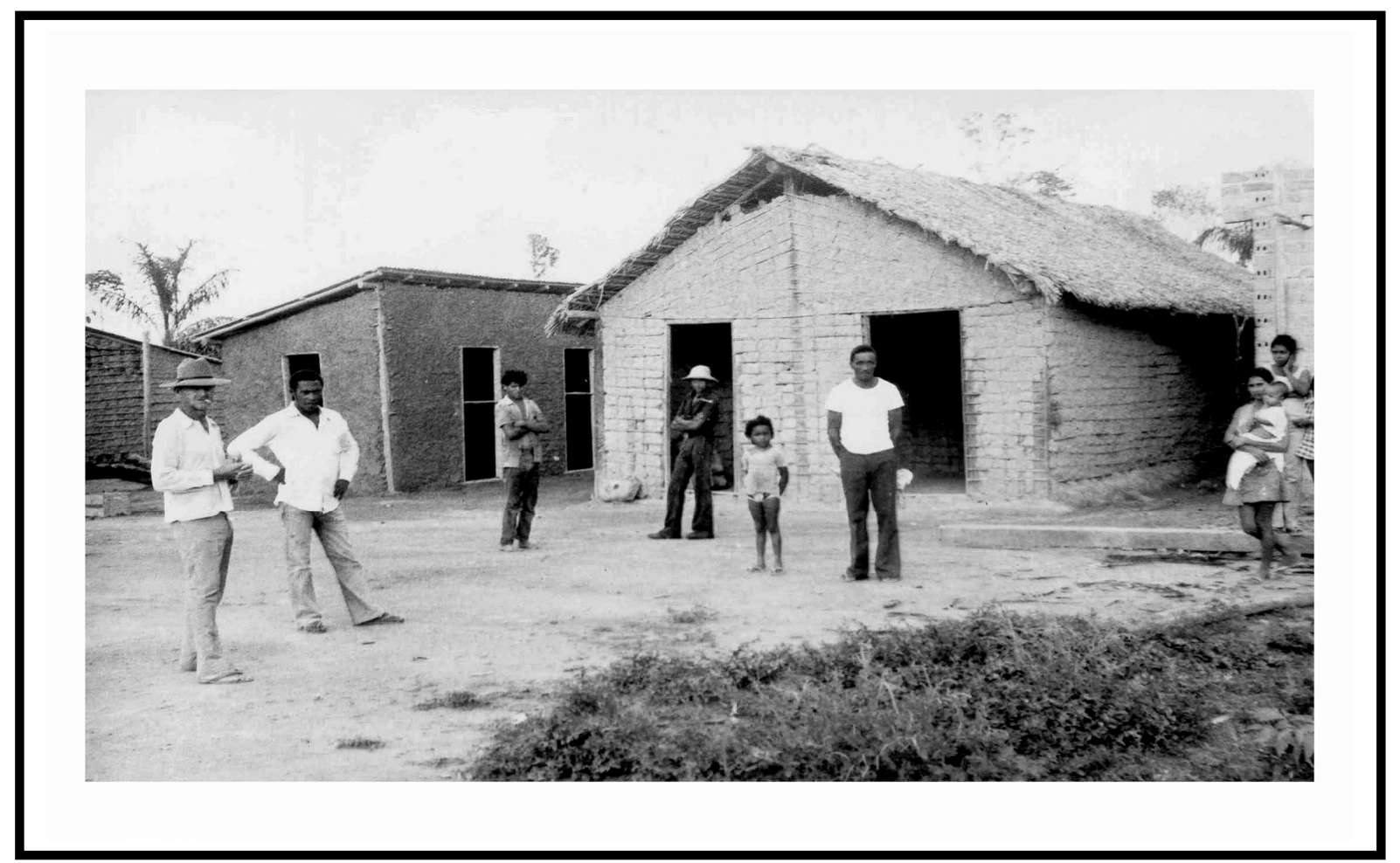

Figura 13: Tipo de Residência em Boa Vista \Déc. 20 - Séc.XX

Foto: Acervo de Tiago Orihuela

$\mathrm{Na}$ dinâmica de produção e reprodução do espaço urbano de Boa Vista, verifica-se que foi a partir do pequeno núcleo inicial, que se deram as ações e intencionalidades que resultram no processo de planejamento de uma cidade na selva, a qual passou a exercer o papel de poder central na fronteira do Brasil Setentrional.

Desta maneira, na avaliação de Silva (2007, p. 205) o desenvolvimento urbano a partir da implantação do plano urbanístico da cidade nesse espaço geográfico está diretamente relacionado com a intervenção e interesse político, uma vez que o objetivo central era dotar a capital do novo território de infra-estrutura (saneamento básico, arruamento, edificações públicas: escola, hospital entre outros), tornando-a uma cidade político-administrativa com o propósito de ocupar e proteger essas plagas. Nas palavras de A. S. JÚNIOR (1993, p. 113) "O surgimento de núcleos populacionais nessa faixa de terra do extremo norte do País foi resultado da necessidade de defender as fronteiras do Brasil de invasões estrangeiras."

Nesse sentido, a análise da produção do espaço urbano de Boa Vista, significa, também, uma análise da (re) construção da cidade a partir da criação do Território Federal de Rio Branco em 1943 e a implantação do Plano Urbanístico por Êne Garcez dos Reis em 1944. 


\section{CAPITULO II: REDEFININDO A FORMAÇÃO SÓCIOESPACIAL DE BOA VISTA A PARTIR DA CRIAÇÃO DO TERRITÓRIO FEDERAL DO RIO BRANCO NO ANO DE 1943 E DA IMPLANTAÇÃO DO PLANO URBANÍSTICO EM 1944}

Neste capítulo, o enfoque é direcionado para a criação do Território Federal do Rio Branco (hoje Roraima) e sua importância no processo de produção do espaço urbano de Boa Vista, uma vez que a cidade foi escolhida para ser a sede do governo do Novo Território. A incursão nessa análise vem ao encontro à integração das instâncias política e ideológica no interior da superestrutura, sobretudo em fase da presença cada vez maior do estado nas formações econômico-sociais na Amazônia setentrional, voltado exclusivamente para as relações de poder, desenvolvimento e controle das fronteiras da região Norte do país. Dando ênfase à implantação do Plano Urbanístico de Boa Vista como sendo uma obra urbanística de fundamental importância no processo de produção de Boa Vista e a que trouxe um novo arranjo espacial na paisagem urbana da cidade.

\subsection{A criação do Território Federal do Rio Branco e sua importância na dinâmica de produção do espaço urbano de Boa Vista}

Como evidencia Santos (1996, p. 16) "o território são formas, mas o território usado são objetos e ações, sinônimo de espaço humano, espaço habitado". Nessa linha de raciocínio, pensamos que a criação do Território Federal do Rio Branco, no ano de 1943 - hoje Roraima -, é resultado de um conjunto de objetos técnicos, incorporados a cidade de Boa Vista através das ações humanas, que são cada vez mais ações informadas, ações normatizadas.

Para Santos (1996, p. 17),

A parcela técnica da produção permite que as cidades locais e regionais tenham um certo controle sobre a porção de territórios que as rodeia [...] esse controle se baseia na configuração técnica do território, em sua densidade, e também, de alguma forma, na sua densidade funcional.

O processo de produção da cidade de Boa Vista, a partir da criação do Território Federal do Rio Branco, insere-se num contexto político-paternalista do Governo Getúlio Vagas, pautado no controle e defesa das fronteiras do Norte do país que resultou na implantação de equipamentos e serviços para torná-la um centro político-administrativo na região do rio Branco. 
A produção do espaço urbano se fez em meio a uma complexa rede de relações que envolve diferentes grupos sociais (pecuarista, fazendeiros, religiosos,o Estado Nacional entre outros), cada qual com seus interesses particulares e estratégias específicas.

Como assevera Roberto Lobato Corrêa (1989, p. 98), essas relações sócioespaciais que norteiam o processo de produção do espaço urbano das cidades estão diretamente ligadas por interesses hegemônicos, ao expor que:

O espaço urbano capitalista - fragmentado, articulado, reflexo, condicionante social, cheio de símbolos e campo de lutas - é um produto social, resultado de ações acumuladas através do tempo, e engendradas por agentes que produzem e consomem espaço. São agentes sociais concretos, e não um mercado invisível ou processos aleatórios atuando sobre um espaço abstrato.

O Governo Central, ao criar o Território Federal do Rio Branco, atuou como grande proprietário fundiário, promotor imobiliário, agente de regulação do espaço e alvo dos movimentos sociais urbanos. Porém foi como provedor de serviços públicos que sua atuação foi mais corrente e esperada, como exemplo há a implantação do Plano Urbanístico, que foi um marco da ação do Governo Central frente ao isolamento dessa região fronteiriça em relação ao restante do país.

Para Trindad Jr (1997, p. 120)

O Estado é um agente que interfere de maneira direta e indireta no espaço urbano. No caso, do estado capitalista sua atuação se dar como grande empresário, consumidor de espaços e de localizações especificas, proprietário fundiário, promotor imobiliário e agentes regulador e definidor do uso do solo. Por outro lado, atua também na implantação de serviços públicos (transporte, saneamento, iluminação). As atividades de renovação e de melhorias urbanas feitas por intermédio do estado são manifestações muito comuns de seu papel enquanto produtor do espaço urbano. É preciso ressaltar, entretanto, que o Estado não é um agente de per se, ou uma superestrutura congelada, imune às contradições e conflitos de classe.

As condições materiais de produção se materializam no plano da cidade, no traçado das ruas e no desenho dos sistemas de engenharia (CARLOS, 2007, p. 74)

No processo de produção da cidade Boa Vista, a intervenção do Governo Central foi essencial na promoção do espaço urbano da cidade, pois contribui de forma decisiva na dinâmica de construção e (re) construção da cidade, enquanto morada do homem. 
Estudos relacionados à intervenção estatal na Amazônia, Silva (2007) e Santos (2004) revelam que foi a partir de 1940 que se deu a interferência republicana na Amazônia, por meio de programas e projetos que visavam a um planejamento regional com base nas características territoriais. No entendimento de Santos (2004, p. 90), a criação do Território Federal do Rio Branco obedeceu a um plano estabelecido, com o objetivo de desenvolver e proteger a região dos invasores estrangeiros na década de 40 do século XX. Uma vez que as Guianas, possessões européias, eram limítrofes do Brasil na Amazônia.

Como parte do território nacional a ser protegido e defendido, o governo Getúlio Vargas achava que a Amazônia estava desprotegida, relegada a segundo plano, dentro do conjunto de um país de dimensões continentais. Tinha receio de uma ação armada para a internacionalização da Amazônia. Acreditava que nossas fronteiras estavam esquecidas e à mercê de ações internacionais. Para amenizar a situação, criou os pelotões do exército de fronteiras para marcar a presença do Brasil em determinados pontos estratégicos onde já havia fixação de populações (FREITAS, 1993, p. 32-35).

Nesse cenário de resguardar e ocupar, foi criado o $1^{\circ}$ Pelotão de Fronteiras de Boa Vista, com o objetivo de articular e proteger melhor as áreas de fronteira da Amazônia, que se traduz em 1943, na compreensão de Silva (2007, p. 116) na criação dos territórios federais do Amapá, do Guaporé, hoje Rondônia e do Rio Branco, que foi assim denominado graças à importância do curso d'água que banha a cidade de Boa Vista.

Em relato verbal sobre a criação dos Territórios Federais publicado por Freitas (1993, p. 33), o Capitão Êne Garcez expõe que:

[...] O que, em princípio, seria apenas a criação de colônias militares, evoluiu para o desmembramento de áreas dos Estados para criar Territórios Federais sob a responsabilidade direta do Governo Federal [...] Esses Territórios Federais teriam como objetivo assegurar o desenvolvimento dessas áreas e também diminuir a carga dos Governos Estaduais. Não seria possível aos governadores estaduais desenvolverem estas regiões com recursos próprios. Só o Governo Federal teria condições de fazer isto. 
Para Silva (2007, p. 117), os Territórios foram criados, como parte de uma política nacionalista de povoar, desenvolver e proteger as fronteiras, em especial onde o Brasil teve problemas de demarcação de limites com a França, Inglaterra e também com a Bolívia. "O Estado Novo usou o discurso propagandístico de "Segurança Nacional", mostrando interesse na redivisão e ocupação do território amazônico" (OLIVEIRA, 2003, p. 173 e 174).

Com a criação do Território Federal do Rio Branco tem-se uma nova divisão geopolítica do país, que englobava em seu espaço geográfico terras e bens do município de Boa Vista e parte das terras dos municípios de Moura e Barcelos, antes sobre o domínio do Estado do Amazonas. Por Decreto-Lei de sua criação, esse imenso território tinha apenas um distrito, que era a capital com o nome simplificado de Boa Vista (FREITAS, 1993, p. 30).

Todavia, no dia 21 de setembro de 1943, foi realizada uma nova divisão territorial, ficando o território dividido em dois municípios, Boa Vista e Catrimani, e estabelecido que a capital fosse Boa Vista (SILVA, 2007, p. 17) (Mapa 5). 


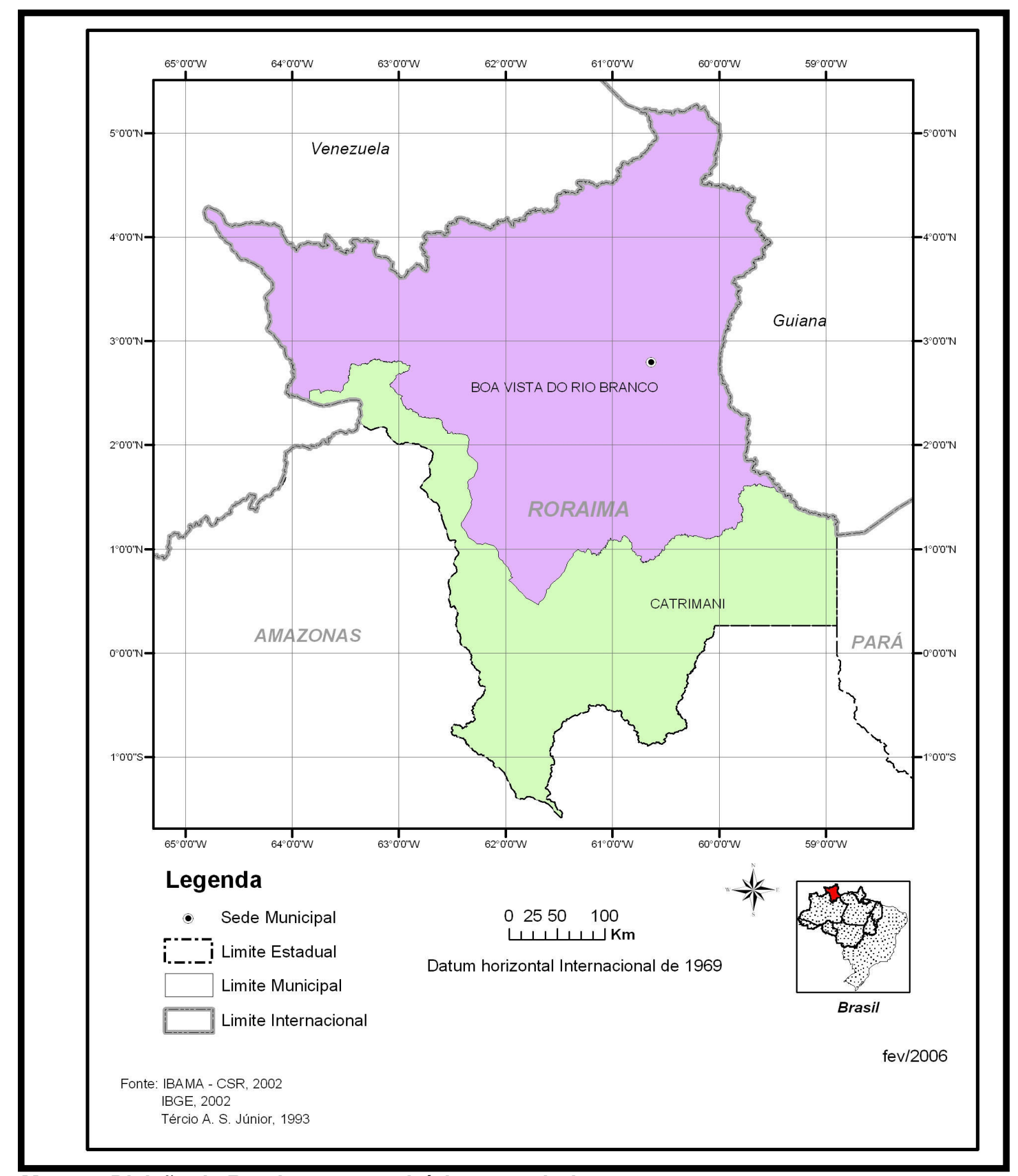

Mapa 5: Divisão de Roraima em municípios a partir de 1943

Organização: Paulo Rogério de Freitas Silva

Fonte: Silva, 2007. 
A criação do novo Território foi responsável, ao lado da mineração e da pecuária - mencionados no capítulo anterior -, que usava Boa Vista como base de apoio, pelo crescimento populacional e ultracentralizador funcional da cidade (BARROS, 1995, p. 62), uma vez que as autoridades políticas não trataram de criar uma capital exclusiva para a sede do novo território. A idéia era dotar o único núcleo urbano - no caso, Boa Vista - de infra-estrutura. Dessa maneira as funções urbanas criadas no vale do rio Branco iriam se estabelecendo nesta cidade.

Após a criação do Território Federal do Rio Branco em 1943, somente em 1944 é que o Presidente Getúlio Vargas nomeia o Capitão Êne Garcez dos Reis para governar o novo Território na capital Boa Vista. Ciente das dificuldades a serem vencidas, forma uma equipe composta por seis profissionais: dois médicos, sendo um sanitarista e outro clínico, um engenheiro, um Técnico do Ministério da Agricultura, o prefeito da cidade, Senhor Mario Homem de Melo e o Advogado do Ministério da Educação, Araújo Cavalcante, para acompanhá-lo. Era o primeiro governador que chegava ao território (FREITAS, 1993, p. 32-35).

O território era uma entidade sem autonomia financeira. O Governo Central era quem Ihe designava o orçamento e estava vinculado ao Ministério da Justiça e Negócios Interiores (CAVALCANTE, 1949, p. 4).

Em 1944, a população do território era de 15000 habitantes e Boa Vista contabilizava 5000 habitantes, a capital possuía três ruas paralelas ao rio Branco, algumas casas de alvenaria, mas, sendo em sua maioria, casas de taipa coberta de palha. Segundo Freitas (1993, p. 32), na época, não existia nenhum prédio específico para abrigar a sede governamental, o Capitão Êne Garcez, estabelece-se na Prelazia do Rio Branco, que ficou sendo o palácio dos despachos. (Figura 14). 


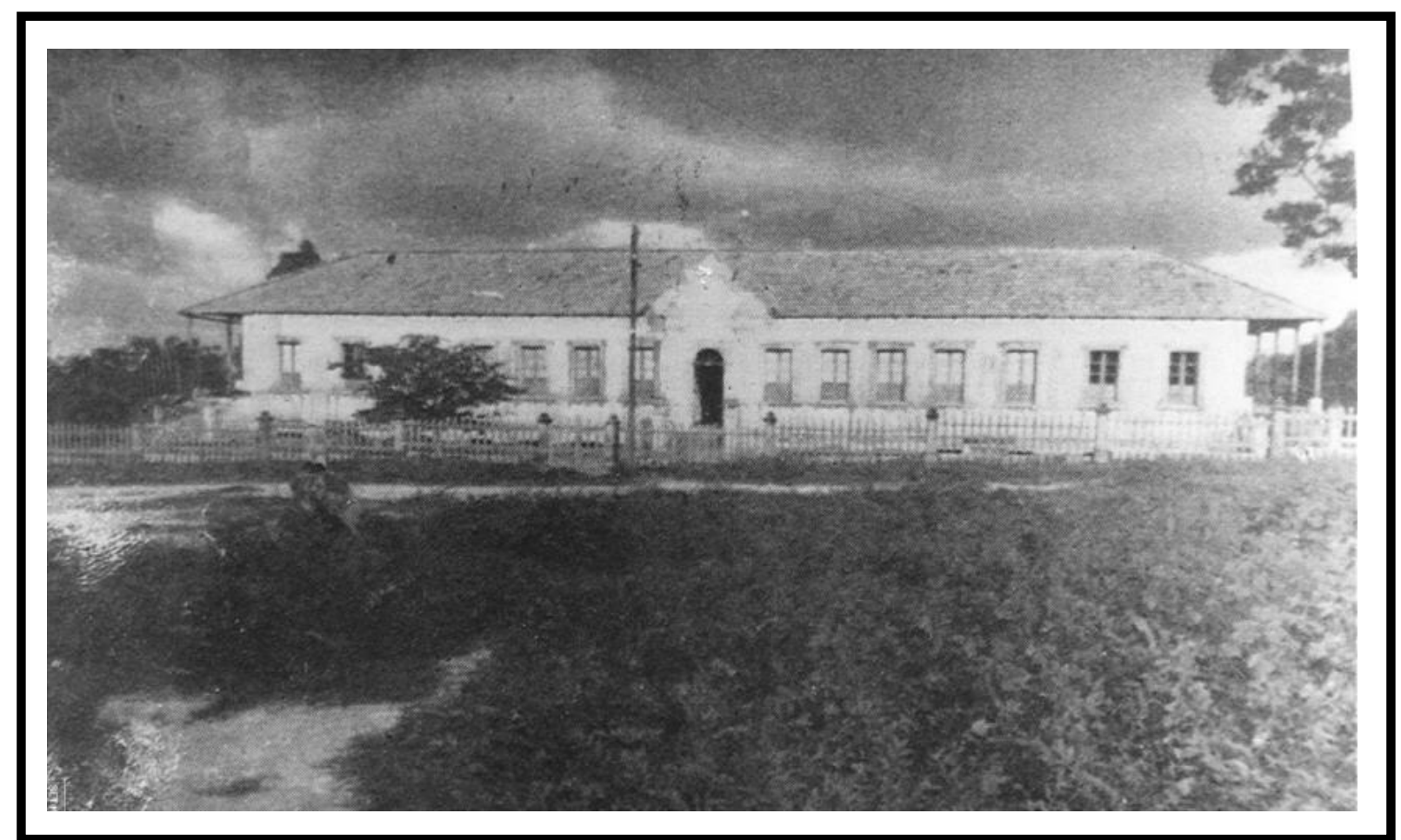

Figura 14: Prelazia do Rio Branco \Déc. 40

Foto: Acervo de Waldir Paixão

Comungando com Freitas (1993), Silva (2007, p. 152) comenta que nesse período, os núcleos considerados urbanos, em Roraima, possuíam uma estrutura muito simples no que se refere aos equipamentos disponíveis. Boa Vista era uma pequena cidade, onde o município possuía uma população de 5 132, tendo acolhido em sua prelazia a sede do governo territorial.

Na opinião de Barros (1995), com a criação do Território Federal do Rio Branco se promoveu um intenso fluxo migratório, principalmente das regiões nordestinas, para atender à demanda do funcionalismo federal e da mão-de-obra não especializada.

Foram implementadas políticas de desenvolvimento e integração da Amazônia ao resto do país, quando, por iniciativa de parlamentares da região, foi aprovado e incluído na nova constituição de 1946 o artigo № 199, que trata da execução do Plano de Valorização Econômica da Amazônia $^{13}$, estabelecendo que a União deveria aplicar na região, durante pelo menos vinte anos consecutivos, quantia não inferior a três por cento de sua renda tributária. O Parágrafo único do referido artigo indicava, ainda, que os Estados e os territórios daquela região, bem como os respectivos municípios, reservariam, para o mesmo fim, anualmente, três

${ }^{13}$ CARDOSO. Fernando Henrique. \& MULLER. Geraldo. AMAZÔNIA: Expansão do Capitalismo. $2^{\underline{a}}$ ed. São Paulo: Editora brasiliense. 1978. 
por cento de suas rendas tributárias. Os recursos de que trata este parágrafo seriam aplicados por meio do Governo Federal.

Portanto a criação do Território Federal do Rio Branco a partir do município de Boa Vista é resultado de um processo de relações internas e externas de políticas de desenvolvimento, de ocupação e de proteção das fronteiras da Amazônia setentrional, tendo Boa Vista como centro das atenções em função de sua posição estratégica e geopolítica em relação aos países da Venezuela e Guiana (Mapa 6) ,e por ser o único aglomerado urbano na região que tinha condições de ser a sede do novo território. 


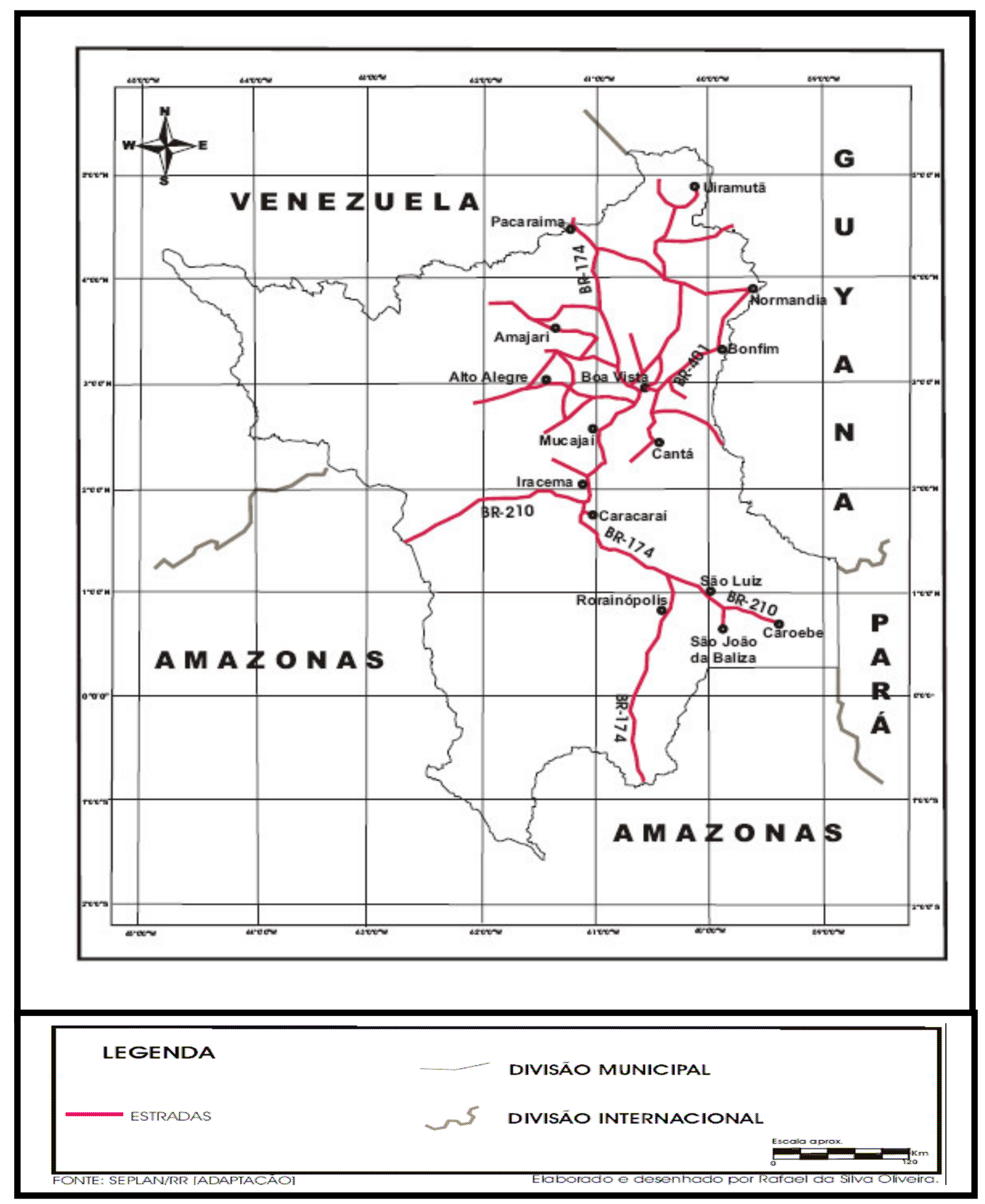

Mapa 6: Posição estratégica e geopolítica de Boa Vista 
pesquisador Antonio Teixeira Guerra (1957) narra que a cidade de Boa Vista funcionava como um centro receptor de migrantes oriundos da Região Nordeste, que se assentavam nas colônias criadas à margem direita do rio Mucajaí, a partir de 1944, a Colônia de Fernando Costa, que ficou conhecida como "Colônia de Mucajaí", e a Colônia de Brás de Aguiar, fundada em 1954, conhecida como Cantá, localizada à distância de $30 \mathrm{~km}$ de Boa Vista.

As famílias, para este e outros projetos no período, eram recrutadas na
própria Amazônia, ou nordeste do país (Maranhão, principalmente).
Recebiam a passagem para chegar a Boa Vista, um mês de alojamento
nesta cidade, e roupas e utensílios domésticos antes de serem transferidos
para as áreas de assentamentos. Situadas nas colônias, essas famílias
recebiam uma mensalidade financeira por nove meses, ferramentas básicas,
medicamentos, e assistência hospitalar em Boa Vista (GUERRA, 1957).

Porém, muitas dessas famílias não permaneciam por muito tempo nos assentamentos, em virtude da descontinuidade do aparato técnico do governo. $\mathrm{O}$ fato é que alguns assentados retornavam para Boa Vista na esperança de conseguir um emprego para sustentar a família. Ao chegarem, não tinham onde morar, o que os obrigava a ocupar irregularmente terrenos insalubres.

Segundo Barros (1995), outro aspecto a ser considerado nesse processo de produção e (re) produção do espaço urbano da cidade de Boa Vista, seria as áreas montanhosas que atraiam migrantes a Boa Vista, considerada o ponto urbano de apoio no auge do garimpo na década de 40. Os garimpeiros, quando necessitavam trocar ou vender o ouro e diamante, além de comprar suprimentos para a garimpagem, deslocavam-se para Boa Vista.

Essas atividades provocaram um fluxo eminente de pessoas para Boa Vista, o que exigia das autoridades competentes uma política de ordenamento territorial local com o objetivo de suprir a cidade de equipamentos e serviços e evitar um crescimento desordenado da cidade.

Nesta entropia, a cidade de Boa Vista tornar-se um centro polarizador e centralizador das ações políticas de ocupação e colonização do território. Apresenta-se, nas palavras de Barros (1995, p. 148), como centro das funções administrativas para toda uma ampla hirtelândia ${ }^{14}$ que depende dela quase exclusivamente. O pesquisador afirma existir desproporcional concentração dos

${ }^{14}$ O conceito de que aqui fazemos uso, hiterlândia, deve-se a BARROS, Nilson Cortez Crocia de. Paisagens e Tempo na Amazônia Setentrional: estudo de ocupação pioneira na América do Sul. Editora Universitária - UFPE. 1995. 
serviços - segurança, justiça, educação, saúde e comércio na capital, como resultado cumulativo de tempos desiguais.

\subsubsection{Realidade sócioespacial do território e sua relação com Boa Vista}

Foi assustadora a primeira impressão do Governador Êne Garcez em relação ao Território e à capital Boa Vista, ao expressar que na região não existia nenhum equipamento e serviço que atendesse a população de forma satisfatória. Nem funcionários qualificados para exercer cargos de confiança. Tal realidade o incitou a realizar um estudo durante quatro meses das principais necessidades do novo território. Dando origem ao primeiro documento de planejamento regional do território, que a princípio não foi atendido pelo Governo Central em razão dos gastos com a II Guerra Mundial (FREITAS, 1993, p. 37).

O Relatório foi elaborado pelo advogado e Técnico em Administração do Governo Federal, Araújo Cavalcanti com apoio do governador, do cientista Beneditino D. Alcuino Mayer e de um grupo de técnicos durante o ano 1944, ao final foi elaborado o Plano Qüinqüenal Territorial de 1945 a 1949. No plano, estavam contidas as informações sobre setores de atividades em que o governo deveria atuar com políticas públicas, com o objetivo de propor um modelo de recuperação e desenvolvimento para o vale do rio Branco.

O relatório tinha como objetivo

- Dar uma compreensão exata da área investigada e seus problemas;

- Possibilitar, em função da análise levada a efeito, a esquematização de programas de trabalho;

- Fazer algumas recomendações de interesse para o território de um modo geral, e os seus habitantes em particular; e

- Lançar as bases da estruturação econômica territorial num sentido de justiça, estabilidade, solidez e equilíbrio (CAVALCANTE, 1945, p.10-11).

Durante a investigação foram considerado os aspectos de ordem geográfica, geo-econômica, antropogeográfica e sócio-política (CAVALCANTE, 1945, p. 30).

Para Cavalcante (1945, p. 134), o principal obstáculo encontrado nos seis primeiros meses de execução do relatório foi o próprio homem. Segundo o autor, cerca de $40 \%$ de indivíduos recrutados revelaram-se incapazes, gananciosos, 
ineficientes - ou seja, uma mão de obra nula frente à necessidade urgente de pôr em prática as políticas de ordenamento territorial local.

Também havia a escassez absoluta de materiais de consumo, de medicamentos [...], a inadequação e insuficiência dos meios de transporte entre outros (CAVALCANTE, 1945).

A realidade sócioespacial da região, exposta no relatório, foi descrita de forma "tenebrosa" por Cavalcanti (1949, p. 68-69) ao comentar que no território predominavam os fatores negativos, frente à situação deplorável, sem a menor preocupação sobre "qualidade", "organização da produção", "cooperativismo" e "serviço social". Segundo Cavalcante (1949), o Governo Federal deveria implementar políticas de desenvolvimento no novo território e ir ao socorro das populações locais, com recursos financeiros e técnicos para dar melhores condições de vida aos seus habitantes.

Seria imprescindível, na analise de Cavalcanti (1949, p.69) providenciar a organização administrativa da nova unidade e seu aparelhamento técnico completo, como pessoal qualificado, financiamento, motores, máquinas, instrumentos de trabalho. Sendo necessário, à priori adotar medidas preliminares e imediatas sobre a propriedade rural, o cultivo da terra, a criação de gado, as indústrias extrativas locais, o ensino profissional, saneamento, assistência médica e colonização.

Os primeiro dados obtidos pelo relatório comprovaram que os habitantes do Território do Federal do Rio Branco em 1944, na sua maior parte, eram acometidos por algum tipo de doença. As residências, na sua maioria, eram de taipa elou de madeira, coberta de palha e geralmente situadas às margens dos rios. Como se evidencia na Figura 15. 


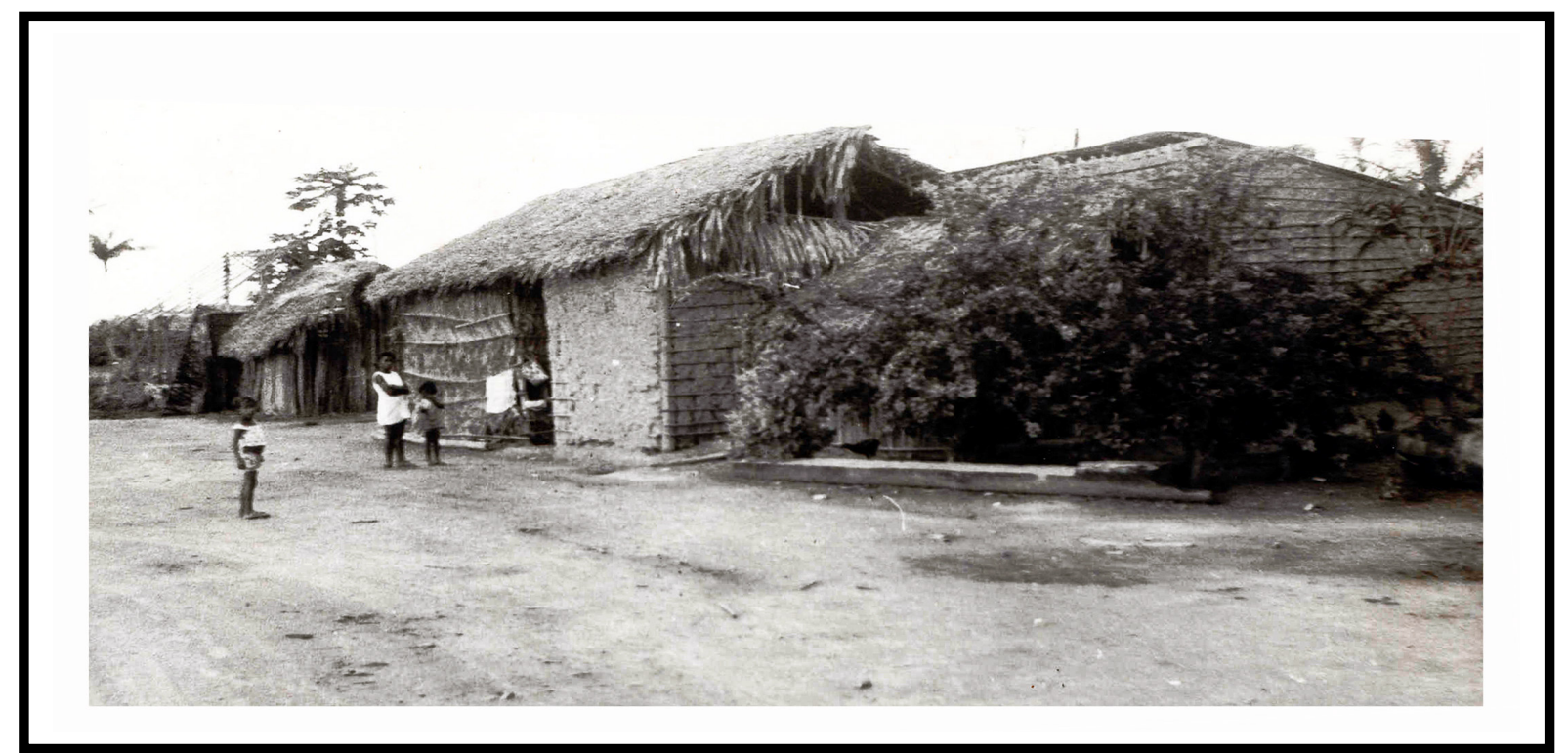

Figura 15: Residências de taipa em Boa Vista \ Déc. 40 - Séc.XX

Foto: Acervo de Tiago Orihuela

Em 1944, a cidade de Boa Vista, tinha 217 mocambos $^{15}$ e 122 casas de alvenaria ou madeira - quase todas em condições inacreditáveis de higiene. A alimentação era precária: carne de gado, caça ou pesca e farinha. E, era tudo. [...] $\mathrm{Na}$ cidade, para uma população de aproximadamente 2.000almas o consumo de leite era de ordem dos 30 litros diários. Também, que toda a população riobranquense era, via de regra subnutrida (CAVALCANTE, 1945, p. 59). Para o autor, havia falta absoluta de higiene. Com exceção da Prelazia dos Beneditinos e de duas casas de fazendeiros locais, o restante era desprovido de fossas sanitárias e banheiros.

Outro registro catastrófico, diagnosticado no relatório, era que $100 \%$ da população de Boa Vista já havia contraído o impaludismo (malária), além de verminose, da sífilis, tuberculose, entre outras doenças. Ademais, a água consumida na cidade era proveniente do rio Branco, a qual se encontrava poluída pelos dejetos das habitações (CAVALCANTE, 1945, p. 45).

Dados do relatório mostravam, ainda, que a maioria da população era anêmica e desnutrida e incapaz para o trabalho. Chegou-se a uma espantosa conclusão: quase não havia pessoas sadias no território e as instituições médico-sanitárias existentes não atendiam à demanda do território e eram mal aparelhadas (CAVALCANTE, 1945, p. 46).

\footnotetext{
${ }^{15}$ Refere-se a habitações miseráveis.
} 
O saneamento do território era inexistente. Não havia saúde no Território Federal do Rio Branco. Desta forma, era imprescindível conjugar os trabalhos no setor de saúde, obras públicas, serviços industriais, produção entre outros, para que a população do território pudesse ter um nível desejável de saúde (CAVALCANTE, 1945, p. 46).

Para Cavalcante (1945, p. 59), o saneamento deveria:

a) Drenar, com revestimento, os igarapés que cercam a capital do território;

b) Estabelecer um serviço de rede de água e esgoto;

c) Tratar as zonas baixa a margem do rio Branco, onde se originou a cidade de Boa Vista;

d) Criar e tratar uma faixa de proteção em torno da cidade (1.000 metros além da última habitação);

e) Efetuar uma campanha intensa de educação sanitária do povo, ao lado de assistência médico-social permanente, simultaneamente com as obras de engenharia sanitária; e

f) Dar início a construção da capital do território e das outras cidades que fossem surgindo, de acordo com o que houver de mais recente ou progressista, em matéria de urbanismo.

O setor educacional era um atraso total, como expõe Cavalcante (1945, p. 60)

\begin{abstract}
O atraso é simplesmente inconcebível. Há mais de $95 \%$ de analfabeto. É mesmo a extrema ignorância das populações ribeiras um dos grandes fatores responsáveis pela falta de saúde existente no território [...] gente humilde que precisando de tudo nada pede aos longínquos governantes; estes dela se lembravam apenas por ocasião dos impostos e das eleições. As quatro escolas existentes no território são malocas infectadas e imprestáveis para fins a que se destinam.
\end{abstract}

Com relação aos meios de transporte, a situação era precária, eles caem dentro das seguintes categorias: a) aéreo; b) fluvial; c) rodoviário e d) tração animal. As medidas para o setor previam a ligação rodoviária entre Caracaraí - Boa Vista, numa extensão de $140 \mathrm{~km}$. Com conclusão dos trabalhos previstos para o final do ano de 1945. Também pretendia pavimentar algumas ruas de Boa Vista. Tudo dentro do projeto de urbanização da cidade.

Desta maneira, percebe-se, que a elaboração do Plano Qüinqüenal, com base no relatório foi de fundamental importância no processo de produção da cidade 
de Boa Vista. Pois as ações a serem executadas estavam pautadas em um planejamento coerente com a realidade local e visava, em linhas gerais, a recuperar e desenvolver o vale do rio Branco, em particular, a capital Boa Vista.

Após a sua conclusão, o plano, foi encaminhado para a apreciação do Presidente Getúlio Vargas. Em 24 de julho de 1945, o presidente baixou o DecretoLei no. 1.115, que dispões sobre a Organização Administrativa do Território Federal do Rio Branco e que lhe confere o art. 180 da Constituição, que Decreta em seu artigo 1: a criação dos Órgãos da Administratção. Assim, constituídos: Governador; Secretaria Geral; Divisão de Saúde (D.S); Divisão de Assistência a Maternidade e a Infância (D.A.M.I); Divisão de Educação(D.E); Divisão de Produção, Terras e Colonização (D.P.T.C); Divisão de Obras(D.O); Divisão de Segurança e Guarda(D.S.G); Serviço de Administração Geral(S.A.G) e Serviço de Geografia e Estatística(S.G.E)(FREITAS, 1993, p. 46-47).

Com a criação dos Órgãos Administrativos o Governador Capitão Êne Garcez propôs uma ação pública, que visava a:

a) Sanear os dois núcleos mais adensados demograficamente. Caracaraí e Boa Vista;

b) Prover o território, com ênfase em Boa Vista, de atendimento médico-sanitário à população doente por meio:

b.1) serviço médico-fluvial para atende a população ribeirinha; postos médicos ao longo dos rios; lanças-ambulância e postos médicos disseminados nos principais núcleos do território;

b.2) centros de saúde (a ser instalado o $1^{\circ}$ em Boa Vista e $02^{\circ}$ em Caracaraí);

c) Fornecer água potável à população;

d) Implantar um sistema de saneamento (fossas e rede de esgotos em Boa Vista e posteriormente em outros núcleos);

e) Fomentar a população de leite, ovos, hortaliças e frutas; e

f) Implantar um sistema de assistência médica contínua, com 0 fornecimento gratuito de medicamentos e hospitalização.

Já o processo de produção (agropecuário e mineral) foi tratado de forma diferenciada, uma vez que era a partir do incentivo ao processo de produção regional e local que se poderia amenizar o estado de subnutrição integral da população, baixar o custo de vida no território em face dos preços exorbitantes, 
elevando a capacidade de consumo dos habitantes e possibilitando a resolução dos problemas de saúde, nutrição, poder aquisitivo entre outro (CAVALCANTE, 1945, p. 61).

Para subsidiar o processo de produção no território, foi criada a Divisão de Produção, que tinha como objetivo geral: estudar, planificar e executar os trabalhos destinados à obtenção dos produtos de produção.

Dessa maneira, uma nova realidade começar a se configura na cidade de Boa Vista. A cidade começar a receber funcionários ligados à administração pública federal, que formaria o starf do governo, uma rede de serviços públicos, o funcionamento do serviço de navegação do território federal e particular e das empresas aéreas que interligava o território ao restante do país (SILVA, 2007, p.153).

Com os desafios a serem vencidos, foram realizadas as primeiras ações com objetivo imediato de suprir o "município território" ${ }^{16}$ - Boa Vista - de infra-estrutura básica (saúde, educação, transporte entre outros), no sentido de amenizar as carências sócioespaciais locais.

No entendimento de Freitas (1993, p. 39), com essa iniciativa, passava-se a priorizar de maneira urgente as necessidades mais importantes da grande "região problema" - saneamento, assistência médica, colonização entre outros, como definia Êne Garcez e Araújo Cavalcante.

Posto nesses termos, percebe-se que o espaço urbano é socialmento produzido, como nos diz Trindade Jr.(1997, p. 5) "a produção dá-se concomitantemente à produção dos bens materiais de que o homem necessita para sua sobrevivência”.

A ação passa a ser um ingrediente fundamental da transformação da natureza humana, ou seja, é um dado sócio-econômico mas é também um tributário das imposições espaciais (SANTOS,1990, p. 137).

Verifica-se, portanto, com base em Trindade Jr (1997) e Santo (1990), que no processo de criação do Território Federal do Rio Branco, o espaço urbano de Boa Vista passou a incorpora novas formas urbanas a partir da inserção de espaços construídos pela ação do homem no decorrer de sua formação sócioespacial, que

\footnotetext{
${ }^{16}$ Termo utilizado para dizer que foi a partir do município de Boa Vista que se deu a criação do Território Federal do Rio Branco em 1943, em função de sua posição geopolítica e estratégica em relação aos países vizinhos: Venezuela e Guiana, e por ser o único núcleo urbano do vale do rio Branco, na época, com capacidade de dar suporte logístico à sede do então território criado.
} 
atribuía novas funções aos objetos fixos, e ao mesmo tempo, funcionava como um sistema (estrutura) na dinâmica de produção do espaço urbano da cidade. Desta forma, a estrutura espacial, isto é, o espaço organizado pelo homem é como as demais estruturas sociais, uma estrutura subordinada-subordinante (SANTOS, 1990, p. 145).

Contudo, foi notório que no sistema de planejamento das ações políticas, no território, desenvolveu-se a concepção de existência da cidade, sobretudo em relação a execução das obras propostas no Plano Urbanístico, que seria o foco irradiador do desenvolvimento da capital Boa Vista, e no qual iriam se concentrar as forças motrizes do progresso e os serviços e equipamentos necessários ao desenvolvimento e recuperação do vale do rio Branco.

$\mathrm{Na}$ verdade, como assevera Corrêa(1989, p. 9), o espaço urbano é "[...] a própria sociedade em uma fase de suas dimensões, aquela mais aparente, materializada nas formas espaciais" 


\subsection{A implantação do plano urbanístico}

Após a criação do Território Federal do Rio Branco, o Governo Federal passou a definir políticas de desenvolvimento urbano voltadas para o controle político, econômico e estratégico da fronteira setentrional. Como exemplo, destacase a elaboração do Plano Urbanístico da cidade no período de 1944 a 1950 pela firma carioca Riobras do Engenheiro Civil Darcy Aleixo Derenusson. A proposta era que a cidade tivesse um traçado de integração urbana, isto é, radial concêntrico, em que, na praça circular, reuniam-se os três poderes - Executivo, Legislativo e Judiciário - e de onde partiam as radiais, extremamente largas, para norte, sul e Oeste, como evidencia o Figura 16. O referido traçado foi idéia do então Governador do Território Capitão Êne Garcez dos Reis, que se inspirou no traçado urbano de Belo Horizonte.

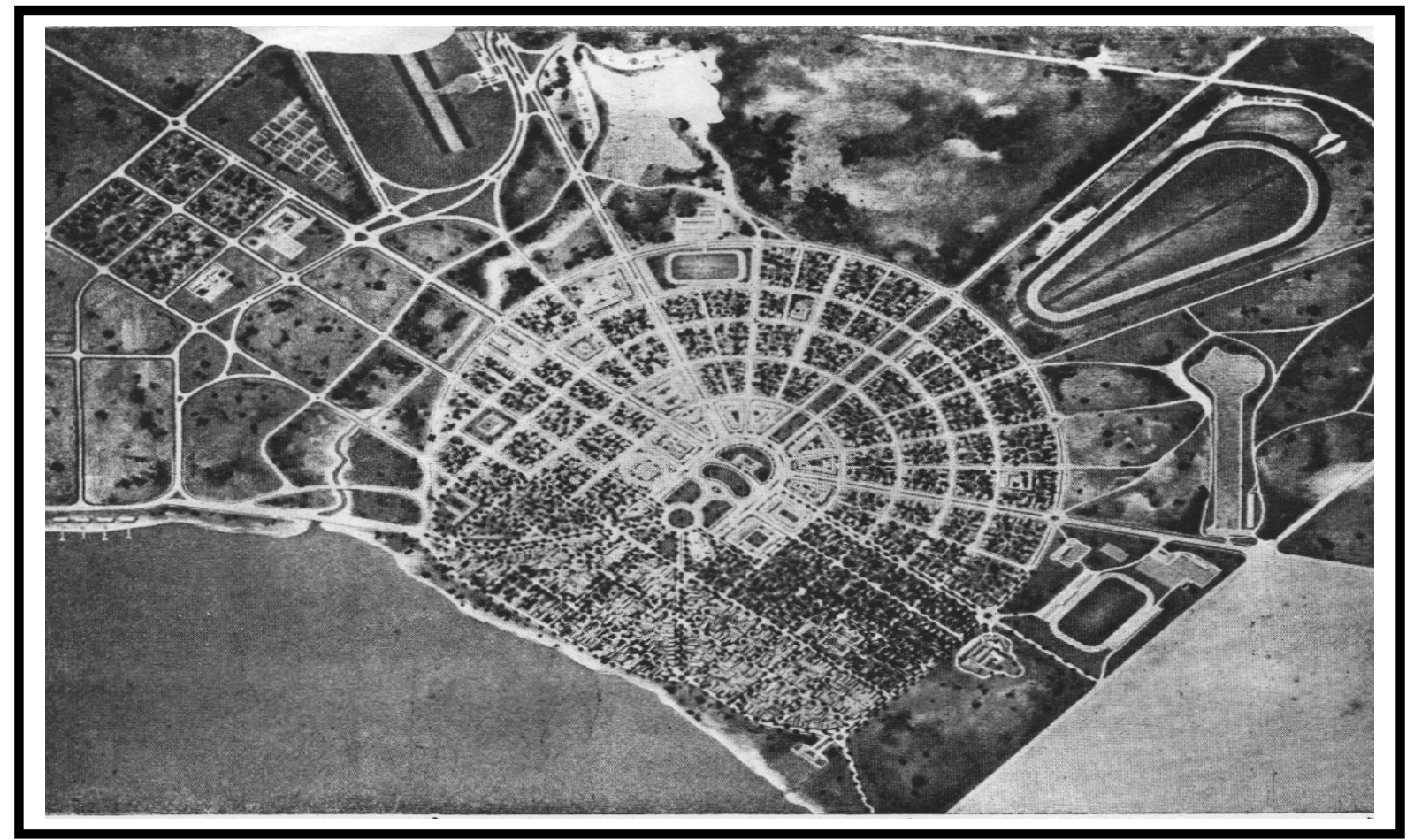

Figura 16: Maquete do Plano Urbanístico de Boa Vista (Traçado Urbano \Radial concêntrico) 1944

Foto: Acervo de Darcy Romero Derenusson 


\title{
2.2.1 O projeto da cidade
}

\author{
A firma do Engenheiro Darcyr A. Derenusson ${ }^{17}$ concorreu com outras três \\ firmas para elaboração do Plano Urbanístico. Não se sabe, no entanto, se a firma foi \\ contemplada em função do valor cobrado, que foi bem inferior aos valores propostos \\ pelas outras empresas, como mostra o Quadro 02, ou se foi a única que atendeu o \\ desejo do Governador Êne Garcez em construir uma cidade com o traçado inspirado \\ em Belo Horizonte, como ele mesmo afirma em entrevista cedida a \\ Freitas (1993, p. 63), \\ Contratei o urbanista Darcy Aleixo Derenusson para planejar a cidade de Boa \\ Vista. O plano da cidade de Boa Vista foi feita por este engenheiro e a \\ inspiração para aquele traçado fui buscar no traçado de Belo Horizonte.
}

\footnotetext{
${ }^{17}$ Carioca, diplomou-se como engenheiro civil pela Escola Nacional de Engenharia da Universidade do Brasil, hoje UFRJ; iniciou o curso em 1935 e concluiu em 1939. Foi professor assistente da disciplina de Topografia e Noções de Aerofotogrametria, na Escola Nacional de Engenharia da Universidade do Brasil - 1940 a 1944.

Executou obras e serviços de engenharia nos estados do Rio de Janeiro, de São Paulo e do território Federal do Rio Branco, na firma individual "Darcy A. Derenusson", destacando-se: execução de mais de duas centenas de levantamentos topográficos na cidade do Rio de Janeiro e nos estados do Rio de Janeiro e de São Paulo; projeto da Estrada das Arcas, em Itaipava - RJ.

Foi autor do Plano de Urbanização de Boa Vista, capital do então Território Federal do Rio Branco, atual Estado de Roraima. De 1944 a 1946, dirigiu e coordenou uma equipe que elaborou o plano da cidade e, até 1950, atuou na execução de obras de urbanização de Boa Vista, com sua empresa, a Riobras, realizando a parte central do atual traçado da cidade. Graças à execução das obras de infraestrutura, tais como esgotos sanitários, esgotos pluviais, abastecimento d'gua, Ênergia elétrica, com sua rede distribuidora e confecção do Código de Obras, a cidade de Boa Vista foi ocupada rigorosamente de acordo com o plano urbanístico. Nessa época, também foram realizadas as seguintes obras em Boa Vista: construção de cais de atracação às margens do Rio Branco; construção de meios-fios, sarjetas e arruamento da Avenida Floriano Peixoto; construção de 10 escolas rurais, com sala de aula e residência para professor; construção da Praça de Esportes Capitão Clovis, constando de arquibancada com vestiário e instalações sanitárias, quadra de tênis, quadra de vôlei e basquete, etc; construção do Hotel de Boa Vista; construção do matadouro modelo; e construção de 20 casas para o IPASE (Informações transcrita da Enciclopédia Itaú Cultural - Arte Visual. Fonte: Site: www.itaucultural.org.br.
} 


\begin{tabular}{|c|c|c|}
\hline $\begin{array}{c}\text { Empresa } \\
\text { Darcy Aleixo Derenusson }\end{array}$ & $\begin{array}{c}\text { Valor Unidade } \\
\text { Cr\$ }\end{array}$ & $\begin{array}{c}\text { Valor Global } \\
\text { Cr\$ }\end{array}$ \\
\hline Topografia & $0,03 \mathrm{~m}^{2}$ & $150.000,00$ \\
\hline Cadastro & 40,00 & $12.000,00$ \\
\hline Urbanização & $18.000,00 \mathrm{~m}^{2}$ & $90.000,00$ \\
\hline Esgotos Sanitário e Pluvial & - & $40.000,00$ \\
\hline Água Potável & - & $20.000,00$ \\
\hline Ênergia Elétrica (Prazo sete meses) & - & $30.000,00$ \\
\hline Custo Total & - & $324.000,00$ \\
\hline $\begin{array}{c}\text { Empresa } \\
\text { Carlos Teles }\end{array}$ & $\begin{array}{l}\text { Valor Unidade } \\
\text { Cr\$ }\end{array}$ & $\begin{array}{c}\text { Valor Global } \\
\text { Cr\$ }\end{array}$ \\
\hline Topografia e cadastro & $0,06 \mathrm{~m}^{2}$ & $300.000,00$ \\
\hline Urbanização & $20.000,00 \mathrm{~m}^{2}$ & $100.000,00$ \\
\hline Esgotos Sanitário e Pluvial & - & $80.000,00$ \\
\hline Água Potável & - & $60.000,00$ \\
\hline Ênergia Elétrica (Prazo onze meses) & - & $60.000,00$ \\
\hline Custo Total & - & $600.000,00$ \\
\hline $\begin{array}{c}\text { Empresa } \\
\text { De Topografia e Urbanização e Construção } \\
\text { LTDA }\end{array}$ & $\begin{array}{c}\text { Valor Unidade } \\
\text { Cr\$ }\end{array}$ & $\begin{array}{c}\text { Valor Global } \\
\text { Cr\$ }\end{array}$ \\
\hline Topografia e cadastro & $0,05 \mathrm{~m}^{2}$ & $250.000,00$ \\
\hline Urbanização & $50.000,00 \mathrm{~m}^{2}$ & $250.000,00$ \\
\hline Esgotos Sanitário e Pluvial & - & $100.000,00$ \\
\hline Água Potável & - & $60.000,00$ \\
\hline Ênergia Elétrica (Prazo doze meses) & - & Não foi estimado \\
\hline Custo Total & - & $660.000,00$ \\
\hline $\begin{array}{c}\text { Empresa } \\
\text { F. Rocha Vilaça }\end{array}$ & $\begin{array}{l}\text { Valor Unidade } \\
\text { Cr\$ }\end{array}$ & $\begin{array}{c}\text { Valor Global } \\
\text { Cr\$ }\end{array}$ \\
\hline Topografia e cadastro & $0,08 \mathrm{~m}^{2}$ & $400.000,00$ \\
\hline Urbanização & $70.000,00 \mathrm{~m}^{2}$ & $350.000,00$ \\
\hline Esgotos Sanitário e Pluvial & - & $100.000,00$ \\
\hline Água Potável & - & $150.000,00$ \\
\hline Ênergia Elétrica (Prazo dez meses) & - & Não foi estimado \\
\hline Custo Total & - & $1000.000,00$ \\
\hline
\end{tabular}

Quadro 02: Orçamento do Plano Urbanístico de Boa Vista \} 1 9 4 4

Fonte: Território Federal do Rio Branco. Diário Oficial. Boa Vistal07-12-1944. №24. Pag.08.

Enfatizando que não se tem conhecimento das outras propostas. Sabe-se apenas que concorreram à licitação.

Resta saber se as outras propostas não eram mais coerentes para a realidade da cidade, independente do valor licitado, pois esse modelo tem suas limitações, como afirmava o próprio Governador Êne Garcez: 
[...] Esse planejamento de cidade tipo Boa Vista, sistema radial-concêntrico tem seus limites. Ele cresce até um determinado limite e daí não pode mais crescer. E no nosso projeto de leque o crescimento deveria ir até a avenida grande circular, daí para frente tinha que ser feito novo plano e não foi feito [...] Fiquei preocupado em saber se a minha idéia de imitar Belo Horizonte teria sido a melhor. Pelo seguinte: a cidade radial, na proporção que vai crescendo, vai apresentando problemas de ligação de periferia com o centro e vice-versa. Nos intervalos das radiais vai formando "quisto" com poucas saídas. Mas, para o tamanho da cidade a que nos propusemos, o sistema radial funcionou. Agora é preciso repensar 0 assunto (FREITAS, 1993, p. 63).

No caso da contratação da empresa, o Governo Federal atuou como um agente modelador do espaço urbano em conjunto com os agentes econômicos e sociais no sentido de estruturar o espaço urbano de Boa Vista. O que nos leva a pensar, como Santos (1985), que "o espaço urbano é um produto social, de ações individuais e coletivas acumuladas sobre o sítio natural através dos tempos".

Após a licitação, houve a assinatura do contrato para a execução das obras. Nessa solenidade, estiveram presentes várias personalidades influentes na época, como evidencia a Figura 17.

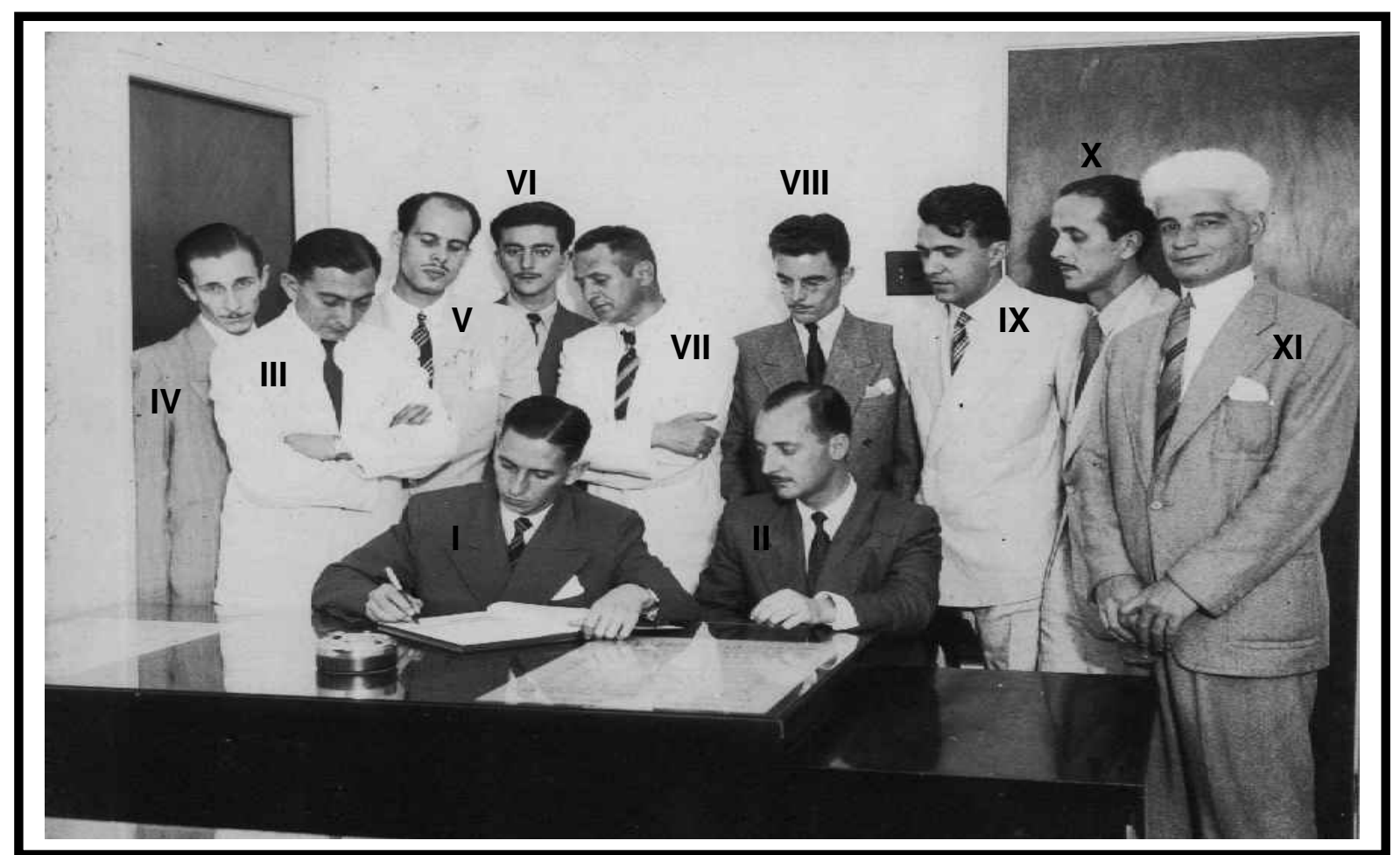

Figura 17: Assinatura do contrato para a execução do Plano Urbanístico da cidade de Boa Vistal1944.

Legenda: I. Governador Capitão Êne Garcez dos Reis \II. Engenheiro Civil Darcy Aleixo Derenusson $\backslash$ III. Eng. Mário Alves \IV. Secretário de Saúde Dr. João de Paula Gonçalves \ V. Dr. Mesquita (médico) \VI. Jayme Fonseca (estagiário) \VII. Tenente Bonolino \VIII. Dr. Walter Pinheiro Guerra \ IX. 1ำ Tenente Paulo Soter da Silveira \X. Jornalista do DIP ( Depart ${ }^{\circ}$. de empresa e propaganda) \ $\mathrm{XI}$. Cronista Pilar Drummond.

Foto: Acervo de Darcy Romero Derenusson 
O Eng. Darcy Aleixo Derenusson ${ }^{18}$, passou sete meses realizando um levantamento da realidade sócioespacial da cidade de Boa Vista com base no relatório realizado pelo Capitão Êne Garcez e sua equipe de técnicos, bem como colhendo informações sobre as carências da população por meio de conversas com a comunidade. Realizou um perfil topográfico da cidade com o objetivo de analisar a situação geográfica da área, na qual seria implantado o plano urbanístico sem que desprezasse o núcleo inicial da cidade (margens do rio Branco). Analisou as medidas de área e perímetro, orientação, variações no relevo entre outros. Executou, o primeiro levantamento topográfico da cidade, que deu origem ao primeiro mapa topográfico (Figura 18). Desenhou, ainda, 1000 plantas, detalhando minuciosamente a quantidade dos materiais necessários a cada obra (JORNAL A GAZETA DE RORAIMA, 1991, p. 05-08).

\footnotetext{
${ }^{18}$ Devido à dificuldade de transporte, Darcy Aleixo Derenusson, levou um mês para chegar a Boa Vista - rio acima, saindo de Manaus. Quando chegou a Boa Vista pela primeira no ano de 1944, a cidade possuía apenas o Hospital Coronel Motta, a Igreja Matriz, a Prelazia e algumas residências. E, a realidade sócioespacial era caótica em relação à demanda por equipamentos e serviços (transporte, educação, saúde pública e saneamento básico) (JORNAL A GAZETA DE RORAIMA, 1991, p. 05-08).
} 


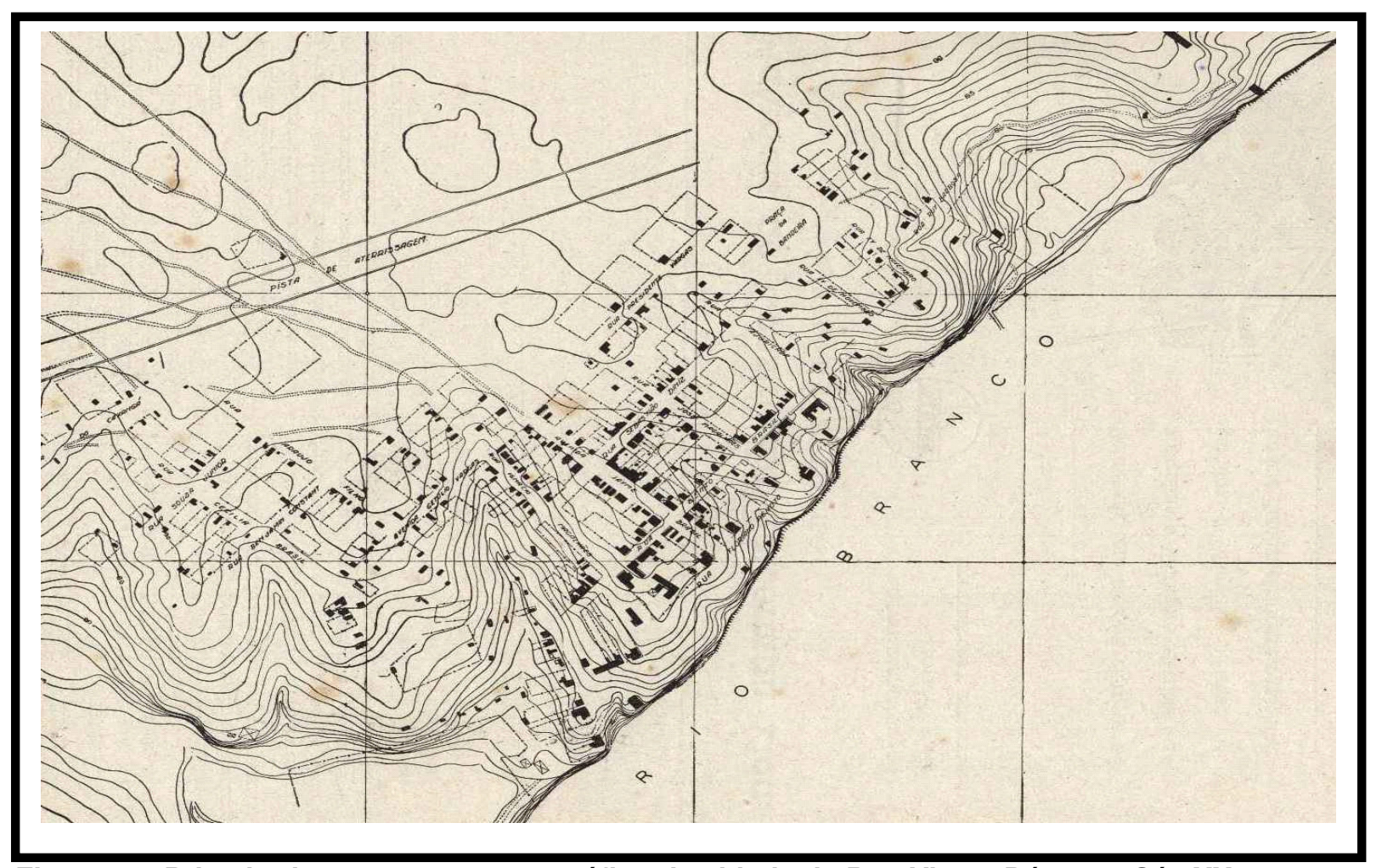

Figura 18: Primeiro levantamento topográfico da cidade de Boa Vista \ Déc. 40 - Séc.XX Foto: Acervo de Darcy Romero Derenusson

O levantamento topografico foi um instrumento de fundamental importância para a implantação (chamadas locações) e acompanhamentos de obras, como: projeto viário, edificações, urbanizações (loteamentos), movimento de terra (cubagem de terra) no processo de implantação do plano urbanístico. Após realizar o levantamento de campo em Boa Vista, o Eng. Darcy A. Derenusson retornou à cidade do Rio de Janeiro para desenhar os mapas e formar a equipe que iria executar as obras.

O Diário Oficial do Território Federal do Rio Branco (1944, p. 8), o relatório de Cavalcante (1945), e as reportagens da Revista Selva (1950) e do jornal Gazeta de Roraima (1991) revelam que os serviços a serem realizados a priori pela firma de Darcy A. Derenusson em Boa Vista, no período de1944 a 1950, englobava:

- Levantamento topográfico plani-altimétrico e cadastral da vila e arredores, numa extensão de 20 km², com a confecção de planta na escala de 1:1000;

- Recenseamento geral da população;

- Estudos sócio-econômicos necessários à elaboração do Plano;

- Elaboração do Plano Diretor da Cidade; 
- Elaboração do Plano de Urbanização, propriamente dito, com detalhamento indispensável à sua execução;

- Elaboração do Código de Obras;

- Projeto de abastecimento de água, inclusive detalhamento da captação, adução e rede distribuidora;

- Projeto da rede coletora de esgotos sanitários (separador) e seu detalhamento;

- Projeto de galerias de águas pluviais e seu detalhamento;

- Projeto de energia elétrica e rede distribuidora com detalhamento;

- Projeto de escolas rurais;

- Projeto de residências; e

- Execução das obras

Os serviços, acima descritos, seriam imprescindíveis no processo de produção da cidade de Boa Vista. Pois, como já dizia o Capitão Êne Garcez - "tudo estava por ser feito".

Infelizmente, em função de crises políticas nacionais, interesses particulares das elites locais e da descontinuidade política existente nas gestões dos exgovernadores, o Plano Urbanistico da cidade não foi executado no período previsto entre os anos de 1944 a 1950.

\subsubsection{As Obras}

Foram iniciadas na gestão do Governo do Capitão Êne Garcez dos Reis. Com a deposição do Presidente Getúlio Vargas em 1946 e a eleição do General Eurico Gaspar Dutra para Presidente da República, no dia 6 de maio de 1946, tomou posse o novo Governador do Território o Major Félix Valois de Araújo, que ficou até o ano de 1948. Depois assume o Capitão Clóvis Nova da Costa em 1948, e governa até 1949, quando é indicado o Sr. Miguel Ximênes de Melo, que governou de 1949 a 1951. Esses três sucessores deram continuidade a execução do Plano Urbanistico da Cidade, bem como fez a maioria dos governadores indicados pelo Governo Central para governar o novo território. Pois, ao assumirem o cargo faziam uso do Plano Quinquenal de Êne Garcez. 
Conforme Freitas (1993, p. 80), o novo Governador - Major Félix Valois de Araújo - chegou no território no ano de 1946 e recebeu os recursos e os projetos elaborados por Êne Garcez e sua equipe, entre eles o Plano Diretor de Boa Vista, para serem executados [...] com os recursos, construiu o primeiro conjunto habitacional do território. Eram 52 casas, algumas ainda existente na atualidade, localizadas nas ruas José Magalhães, Getúlio Vargas (dois lados), Benjamin Constant e Coronel Mota (Figura 19).

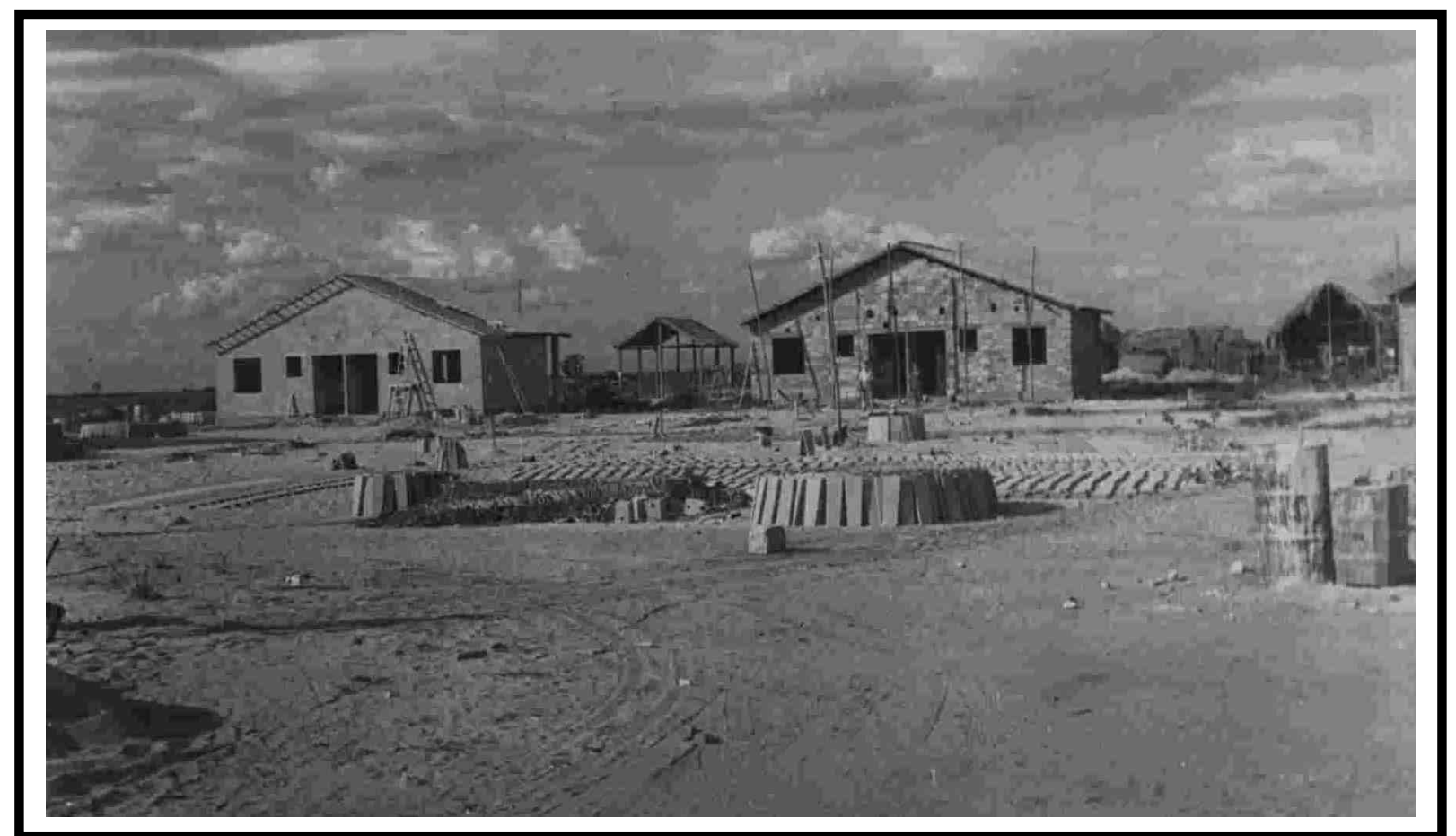

Figura 19: Obras do primeiro conjunto habitacional \Déc.40. - Séc.XX

Foto: Acervo de Darcy R. Derenusson

Foi uma obra de fundamental importância para o período. Uma vez que a carência por moradia na cidade era uma emergência frente à precariedade da maioria das residências. No mesmo período, foi executada a obra de construção do grupo escolar Lobo D'Almada (FREITAS, 1993, p. 80) (Figura 20). 


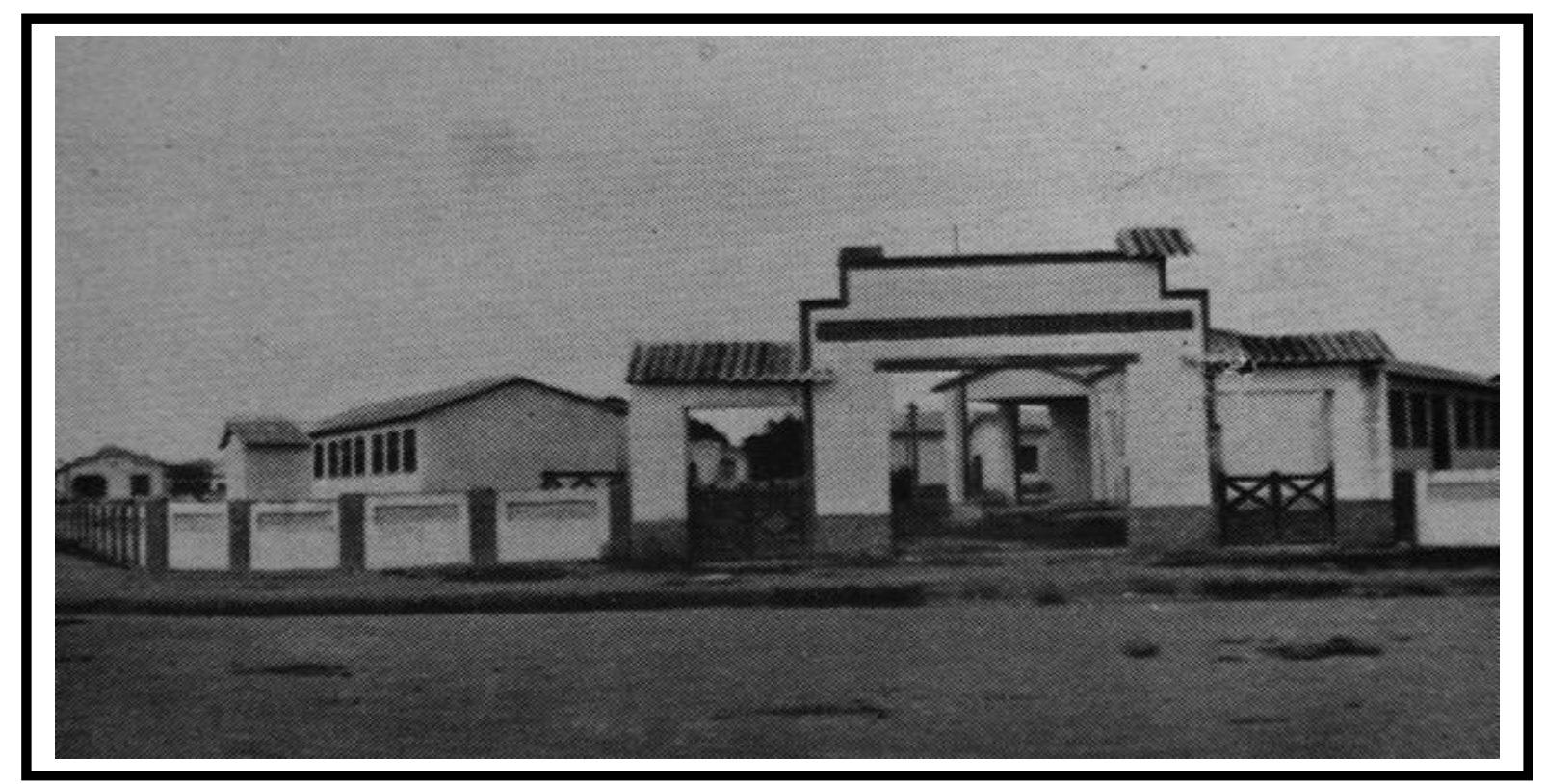

Figura 20: Colégio Lobo D’Almada \Déc. 50 - Séc.XX

Foto: Acervo de Waldir Paixão

Com a construção desses equipamentos urbanos a cidade passa a incorporar uma nova configuração espacial; e sua paisagem urbana, um novo panorama espacial. A dinâmica sócioespacial passa por uma tranformação estrutural em que mantém uma íntima ligação com as formas.

Para Trindade Jr (1997, p. 10) essa dinâmica acontece quando velhas formas são alteradas para uma adequação às novas funções, significa dizer que a organização espacial existente não atende de maneira eficaz a dinâmica social de um novo momento histórico. Alteram-se, portanto, as formas e o uso do solo, levando o espaço a se adequar ao movimento que lhe dá dinamismo.

A partir das construções no espaço urbano de Boa Vista, os objetos fixos, a forma - escola, praça, hotel entre outros, passam a ter uma relação funcional que cria uma fluidez estrutural entre eles, os quais num futuro próximo poderá vir a cumprir outra função social, como explica Santos (1985, p. 55), ao afirmar que: sendo a forma um resultado, ela é também um fator social. Uma vez que é produzida e usada na execução da função que Ihe foi destinada, a forma poderá num dado momento dinâmico da sociedade ser chamada a cumprir uma nova função. 
No que concerne a mão-de-obra utilizada na década de 40 para a execução das obras, quase em sua totalidade, os homens da cidade viviam do garimpo e, por isso, não havia mão-de-obra disponível em Boa Vista. Existia uma lenda que dizia: "O garimpeiro que utilizasse as mãos para trabalhar em outra atividade que não fosse o garimpo nunca mais encontraria ouro ou diamante". Situação que dificultava o processo de execução das obras. Também havia a dificuldade de se obter material de construção - quando, resolve o engenheiro civil Darcy A. Derenusson estabelecer a empresa Riobras Industrial Ltda (Figura 21) para suprir a demanda deste tipo de material, em particular de telhas e manilhas de barro vidrado, para obras de esgoto pluvial, entre outras. A empresa (olaria) localizava-se as margens do rio Branco (REVISTA SELVA, 1950, p. 21-27) e tinha uma capacidade de produção de até 400 tubos diários (manilhas).

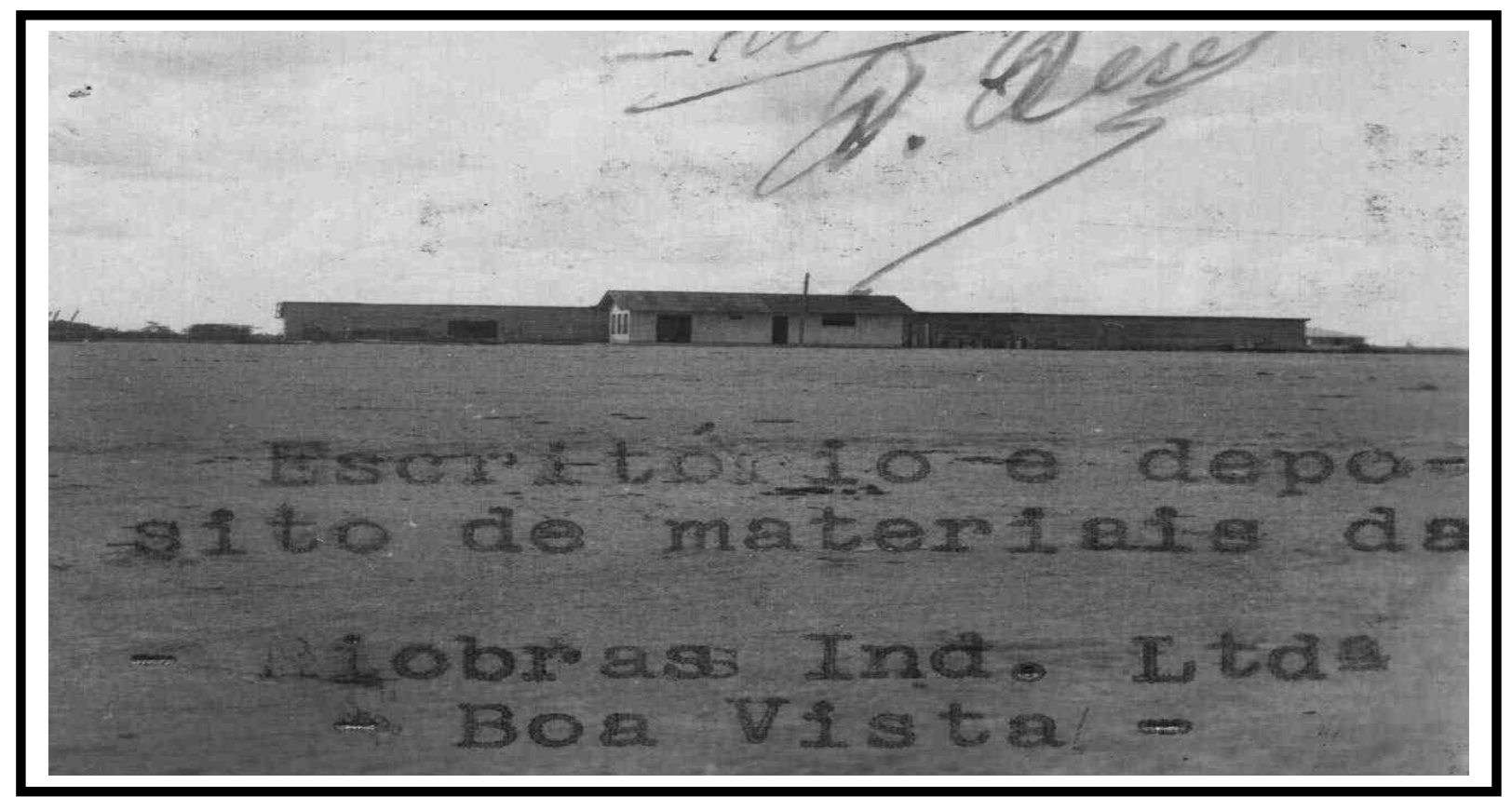

Figura 21: Riobras Industrial Ltda \Déc.40 - Séc.XX

Foto: Acervo de Darcy R. Derenusson 
A Riobras teve de procurar mão-de-obra em outros estados. Chegou a contar com cerca de 2.500 operários, trazidos de Manaus, São Paulo e Rio de Janeiro (Figura 22). A vinda desses trabalhadores contribuiu para o crescimento da cidade e, de certa forma, alterou o comportamento sócioespacial de Boa Vista em relação à demanda por equipamento e serviços, que no período não supria as necessidades da população. Muitos permaneceram na cidade e constituíram família, as quais foram fundamentais no processo de produção da cidade, pois exerceram funções no setor público, de que até então o território era carente (JORNAL A GAZETA DE RORAIMA, 1991, p. 5-8).

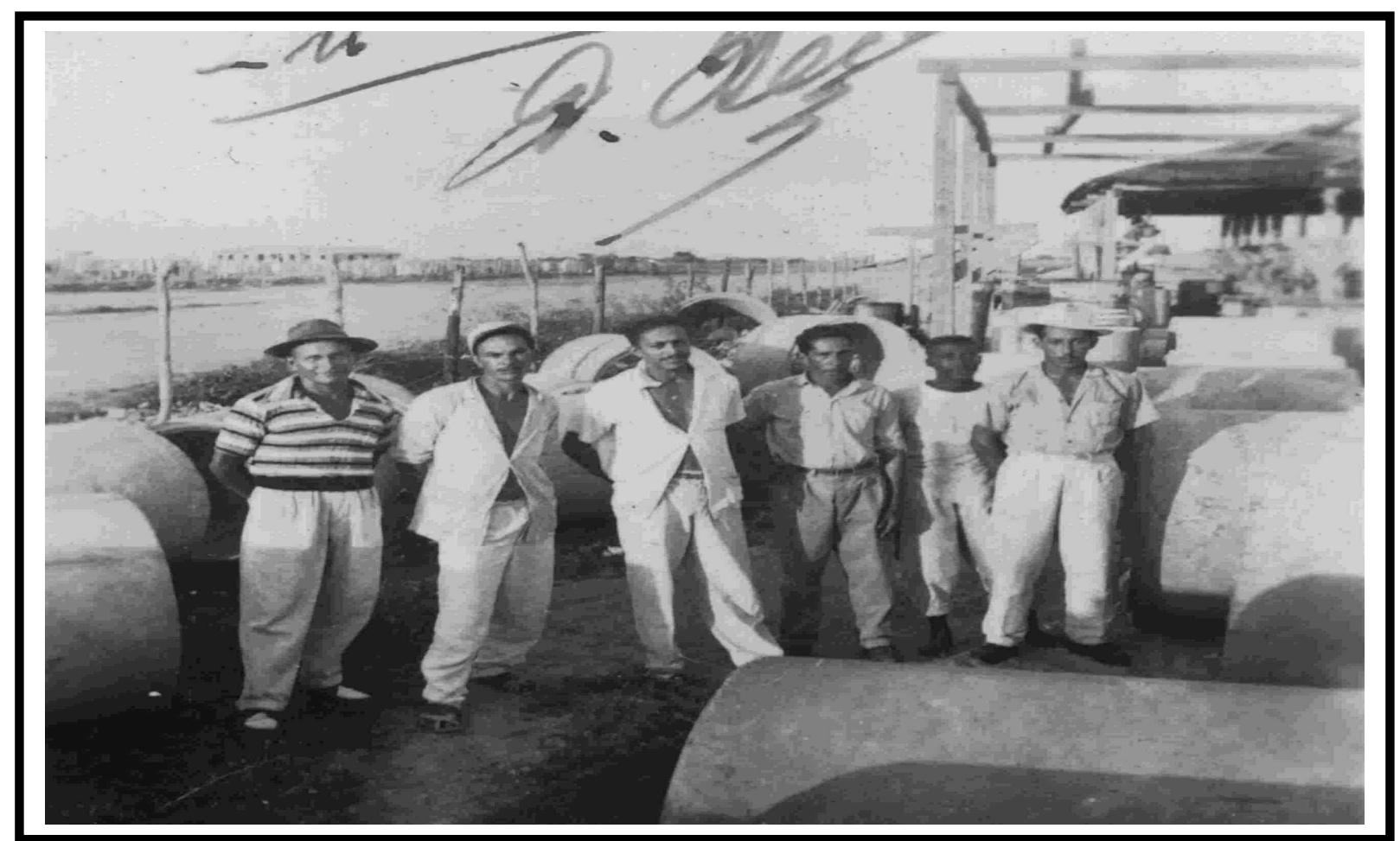

Figura 22: Os pioneiros na construção de Boa Vista \Déc. 40 - Séc.XX Foto: Acervo de Darcy R. Derenusson

A cidade passa a ser o lócus da concentração dos meios de produção e de pessoas ligadas à divisão técnica e social do trabalho, articuladas ao processo produtivo. Ela passa, então, a ser analisada enquanto concentração de instrumentos de produção, serviços, mercadorias, infra-estruturas, trabalhadores entre outros (MOTA \& MENDES, 2006, p. 124). 
Essa dimensão de produção é fundamenta no processo de construção da cidade. Como afirma Carlos (2007, p. 57), a cidade constitui algo não definitivo; não deve ser analisada como um fenômeno pronto e acabado, pois as formas que assume ganham dinamismo ao longo do processo histórico. Assim, o conjunto de objetos criados pelo homem na cidade de Boa Vista são expressões da produção material do homem, resultado de seu trabalho social.

Para Corrêa (1990, p. 57)

\begin{abstract}
A organização espacial é assim constituída pelo conjunto das inúmeras cristalizações criadas pelo trabalho social. A sociedade concreta cria seu espaço geográfico para nele se realizar e reproduzir, para ela própria se repetir. Por isto, cria formas duradouras que se cristalizam sobre a superfície da terra. Caso contrário, insistimos, a sociedade se extinguiria.
\end{abstract}

Dentro desse quadro a (re) produção do espaço é também o da reprodução da vida humana. Como diz Carlos (2007, p. 79) "o homem vive onde ele pode morar e isso será determinado por sua renda e pelos sacrifícios que pode fazer".

Outro ponto a destacar é que durante o processo de execução do Plano Urbanístico de Boa Vista, algumas ações técnicas e educativas foram adotadas no sentido de garantir um bom andamento das obras, entre elas destacam-se:

- Aproveitamento do arruamento e as construções existentes, visando a não alterar o traçado inicial do núcleo embrionário da cidade;

- Decreto Lei proibindo qualquer nova construção antes da entrega do plano urbanístico com o objetivo de evitar construções indevidas na área destina para a implantação do plano;

- Conscientização da população com o objetivo de esclarecer a importância do plano e seu benefício para os diferentes setores administrativos do município: saúde, educação, transporte, entre outros (JORNAL A GAZETA DE RORAIMA, 1991, p. 5).

$\mathrm{Na}$ execução das primeiras obras, o Eng ${ }^{\circ}$ Darcy A. Derenusson solicitou ao governador da época que, antes de construir a cidade, desse prioridade ao sistema de redes de esgoto sanitário e de águas pluviais em função do levantamento que tinha realizado e o qual tinha comprovado que a maioria da população sofria de alguma enfermidade decorrente da ausência de saneamento básico.

Desta maneira, a um só tempo, foram rasgadas todas as rua para a implantação do sistema de redes de esgoto sanitário e águas pluviais. 
Entre as ruas e avenidas, destacam-se:

a) Avenida Floriano Peixoto (Figura 23 e 24):

- Servicos executado: Meios fios, bancos, balaustrada, muralha, galeria de águas pluviais, postes, passeio, rampa de concreto e cais de atracação.

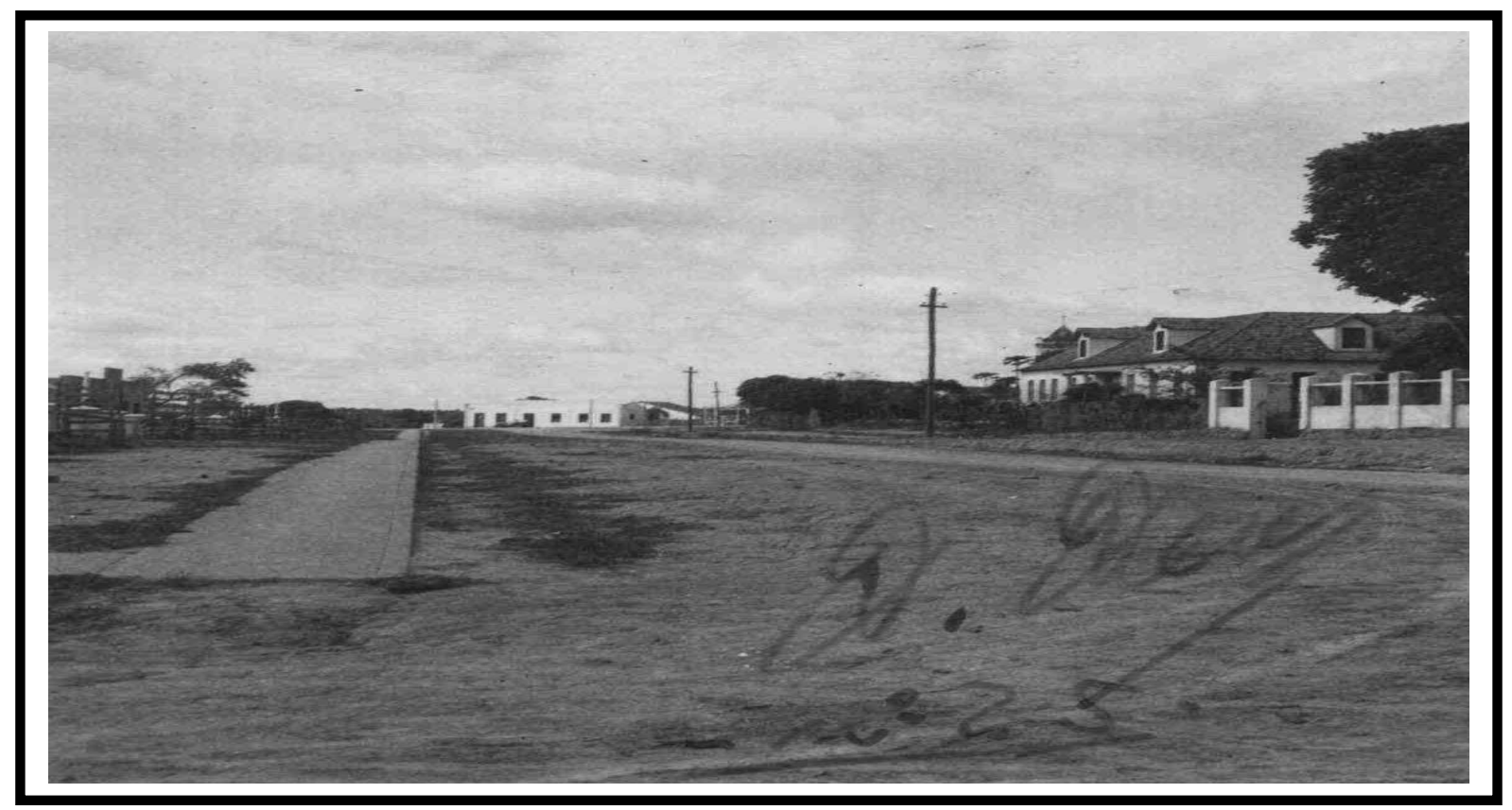

Figura 23: Avenida Floriano Peixoto \Déc. 40 - Séc.XX

Foto: Acervo de Darcy Romero Derenusson

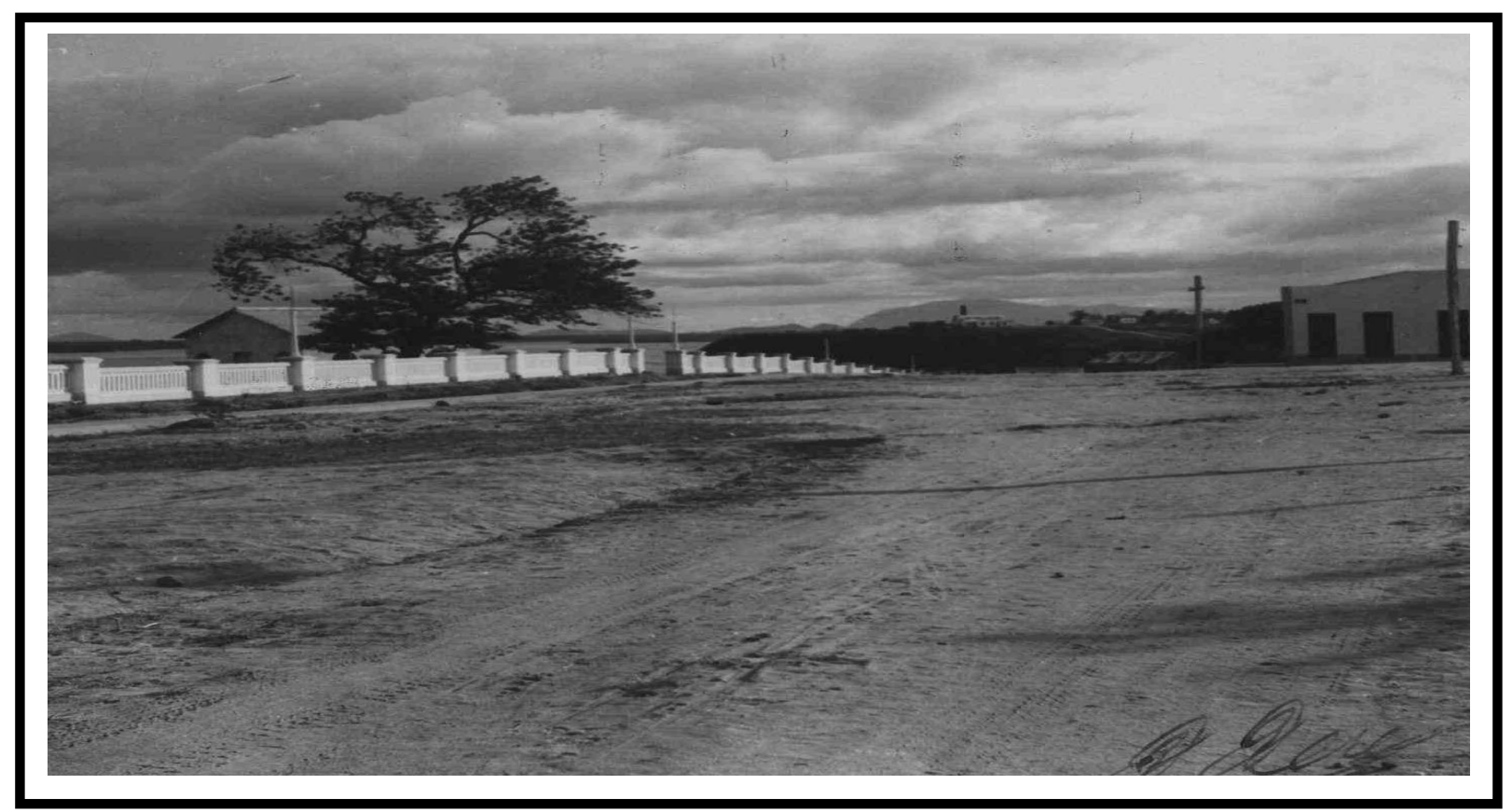

Figura 24: Avenida Floriano Peixoto \Déc. 40 - Séc.XX

Foto: Acervo de Darcy Romero Derenusson 


\section{b) Rua Bento Brasil (Figura 25):}

- Serviços executado: Abertura de vala e colocação de tubos de concreto vibrado.

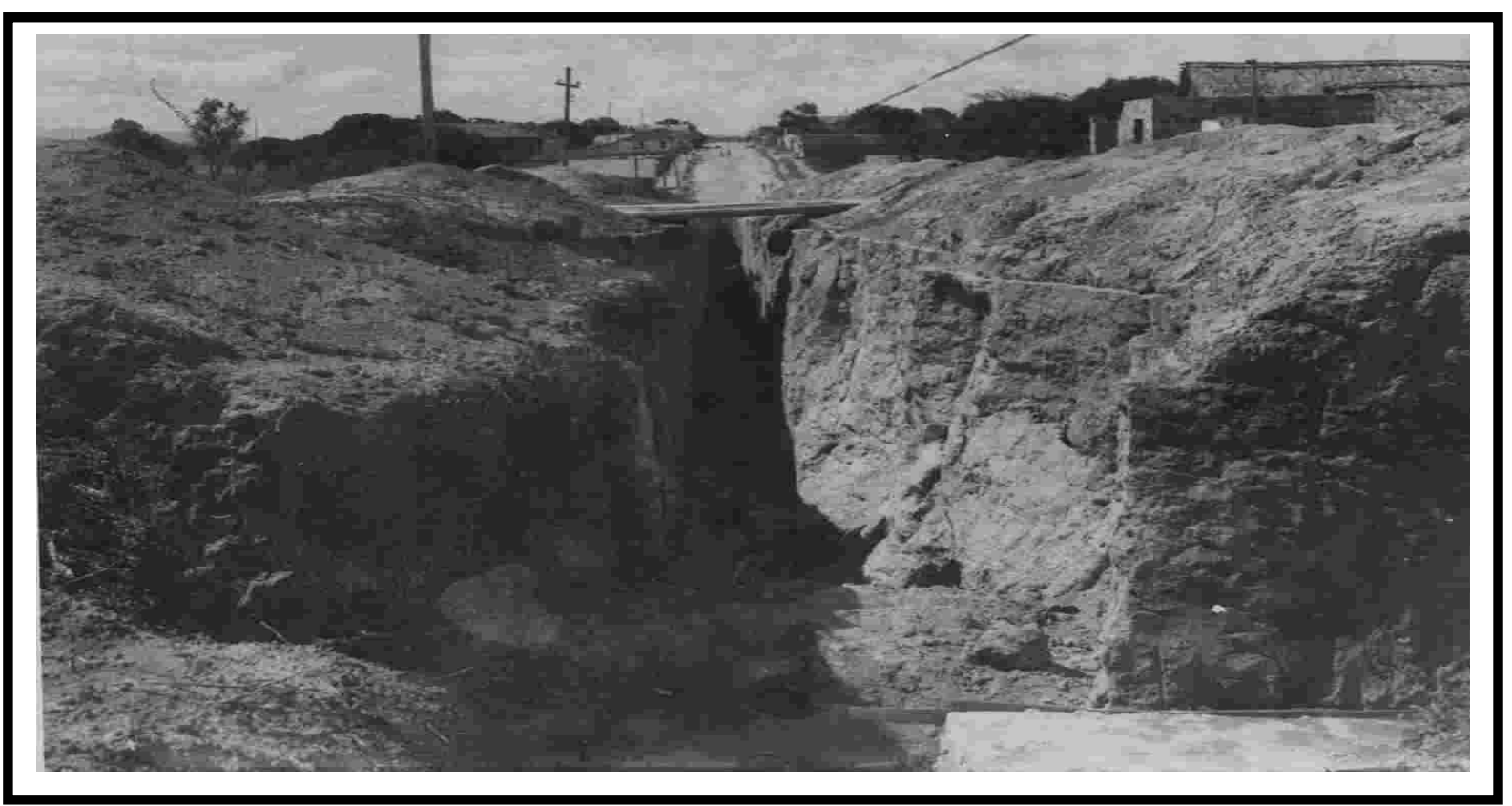

Figura 25: Rua Bento Brasil \Déc. 40 - Séc. XX

Foto: Acervo de Darcy Romero Derenusson

\section{c) Rua Benjamin Constant (Figura 26):}

- Serviços executado: Galerias de águas pluviais.

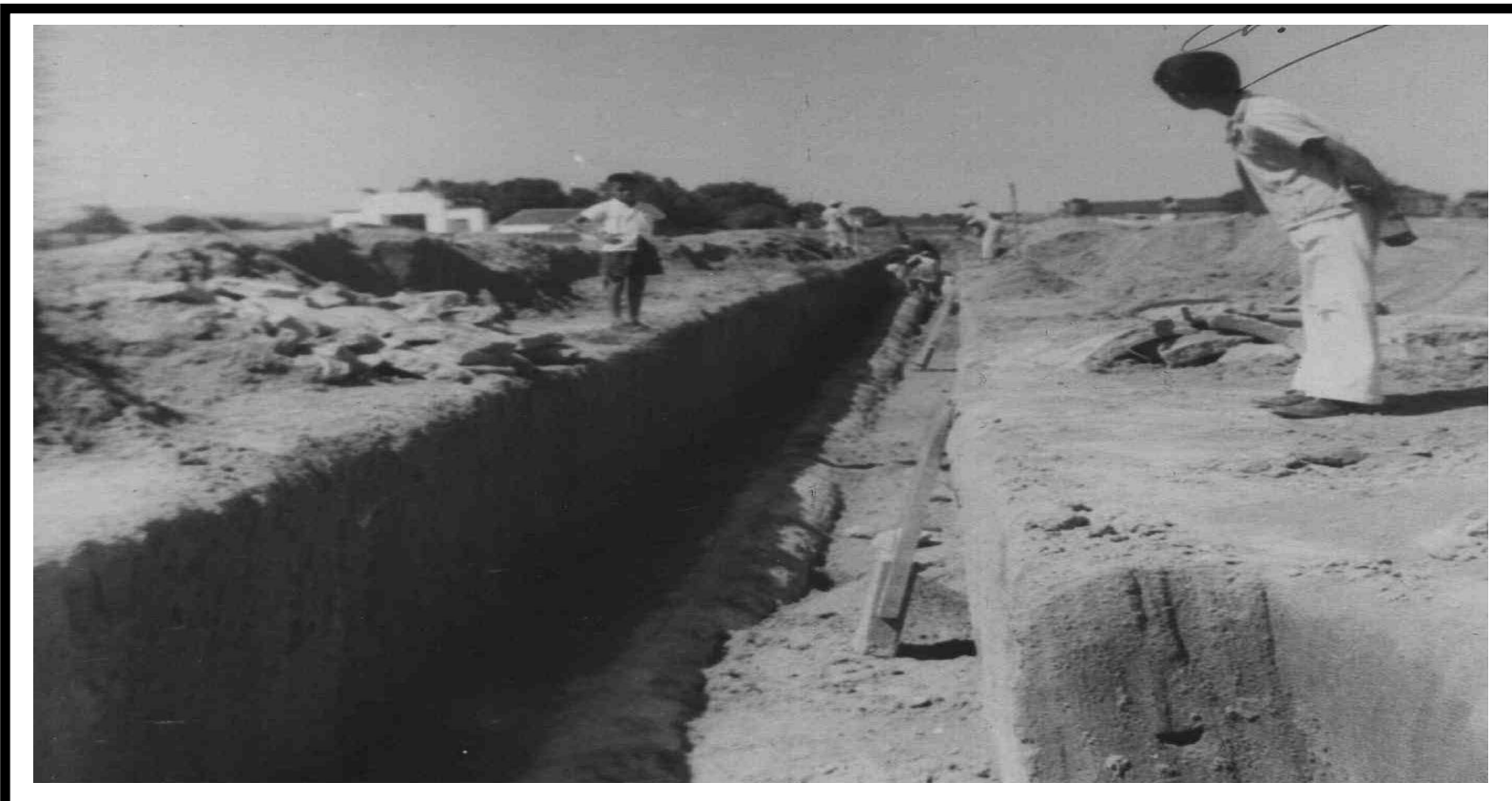

Figura 26: Rua Benjamin Constant/Déc.40

Foto: Acervo de Darcy Romero Derenusson 
d) Avenida Jaime Brasil (Figura 27 e 28).

- Serviços executado: Galerias de águas pluviais e tampão da caixa de areia.

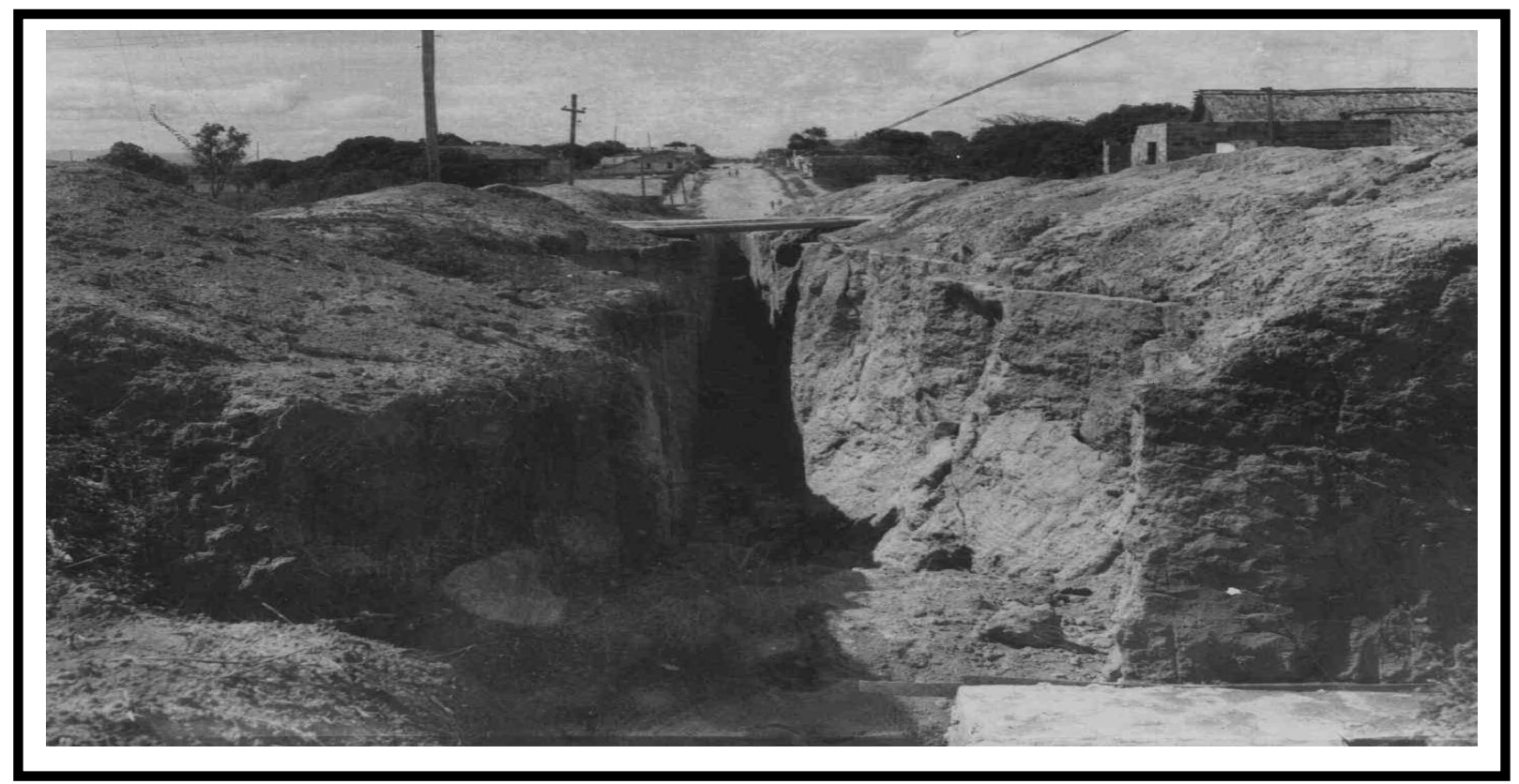

Figura 27: Avenida Jaime Brasil \ Déc. 40

Foto: acervo de Darcy Romero Derenusson

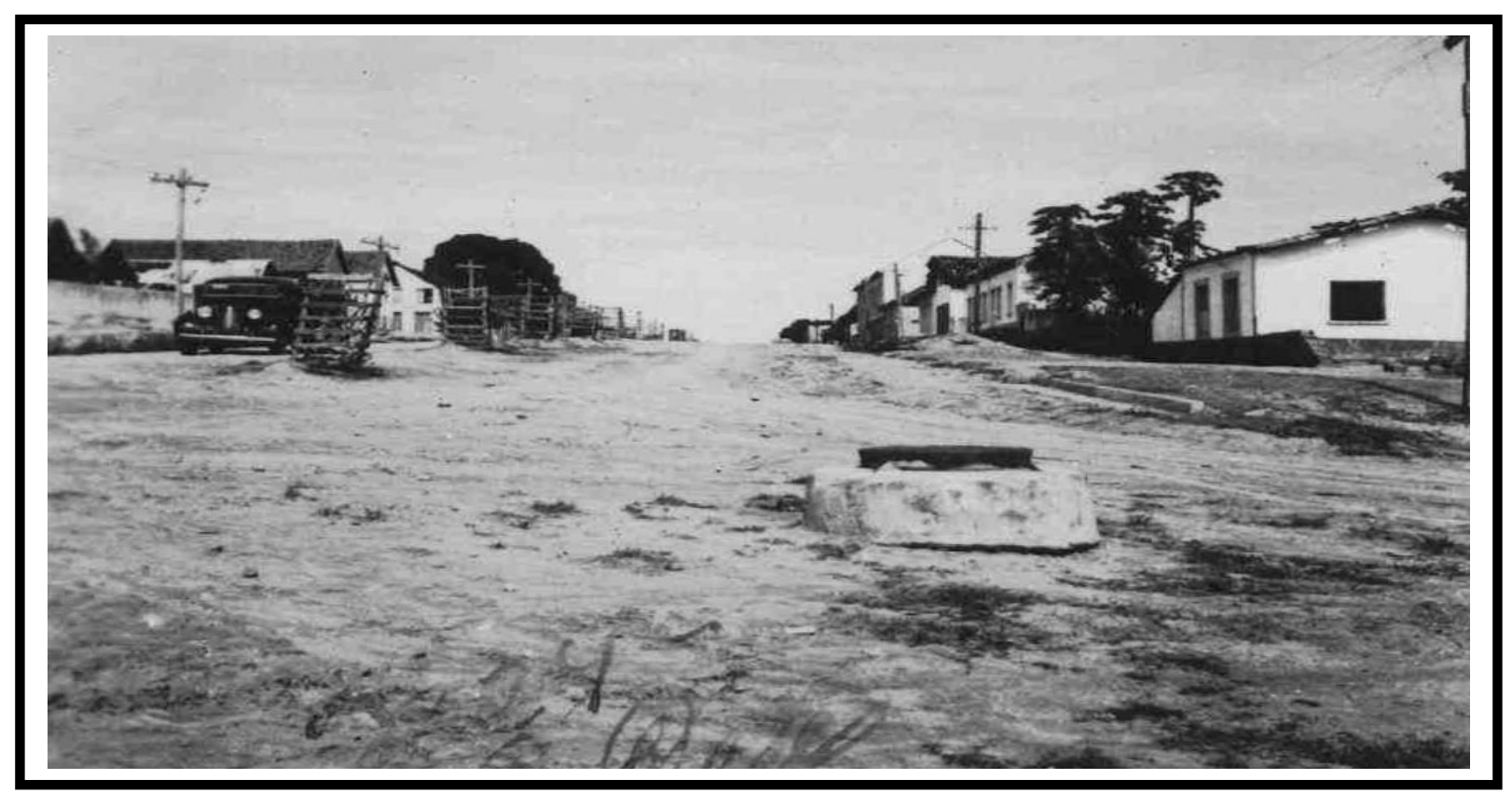

Figura 28: Avenida Jaime Brasil \ Déc. 40

Foto: acervo de Darcy Romero Derenusson 


\section{e) Rua 5 de Setembro (Figura 29)}

- Serviços executado: Galerias de águas pluviais.

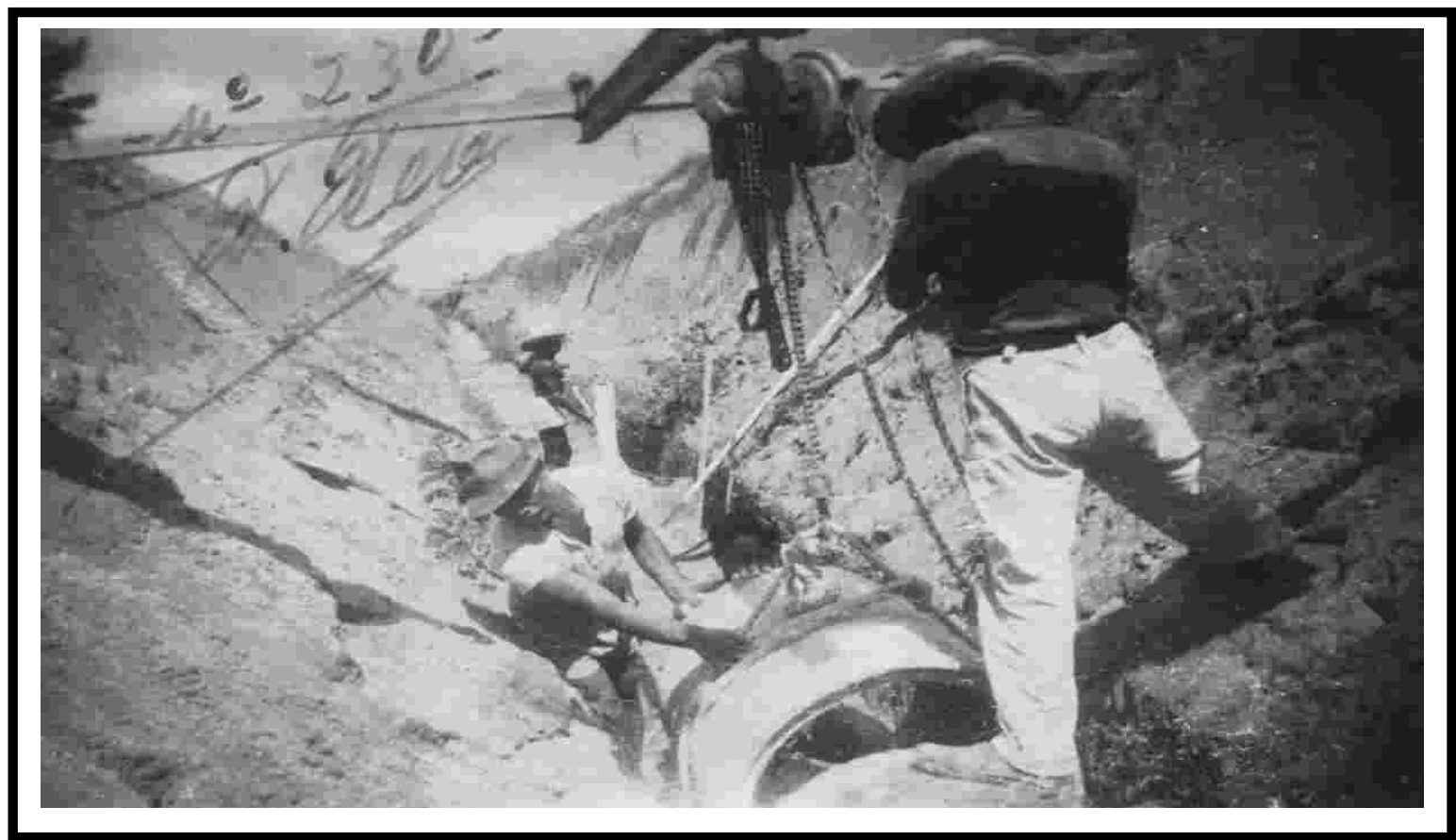

\section{Figura 29: Rua 5 de Setembro $\backslash$ Déc.40}

Foto: acervo de Darcy Romero Derenusson

Ao mesmo tempo, foram construídos prédios governamentais, conjuntos habitacionais, escolas rurais, praças entre outros. Entre as principais construções destacam-se: 
1. Residência do Governador \ Déc. 40 (Figura 30), localizada na Av. Jaime Brasil.

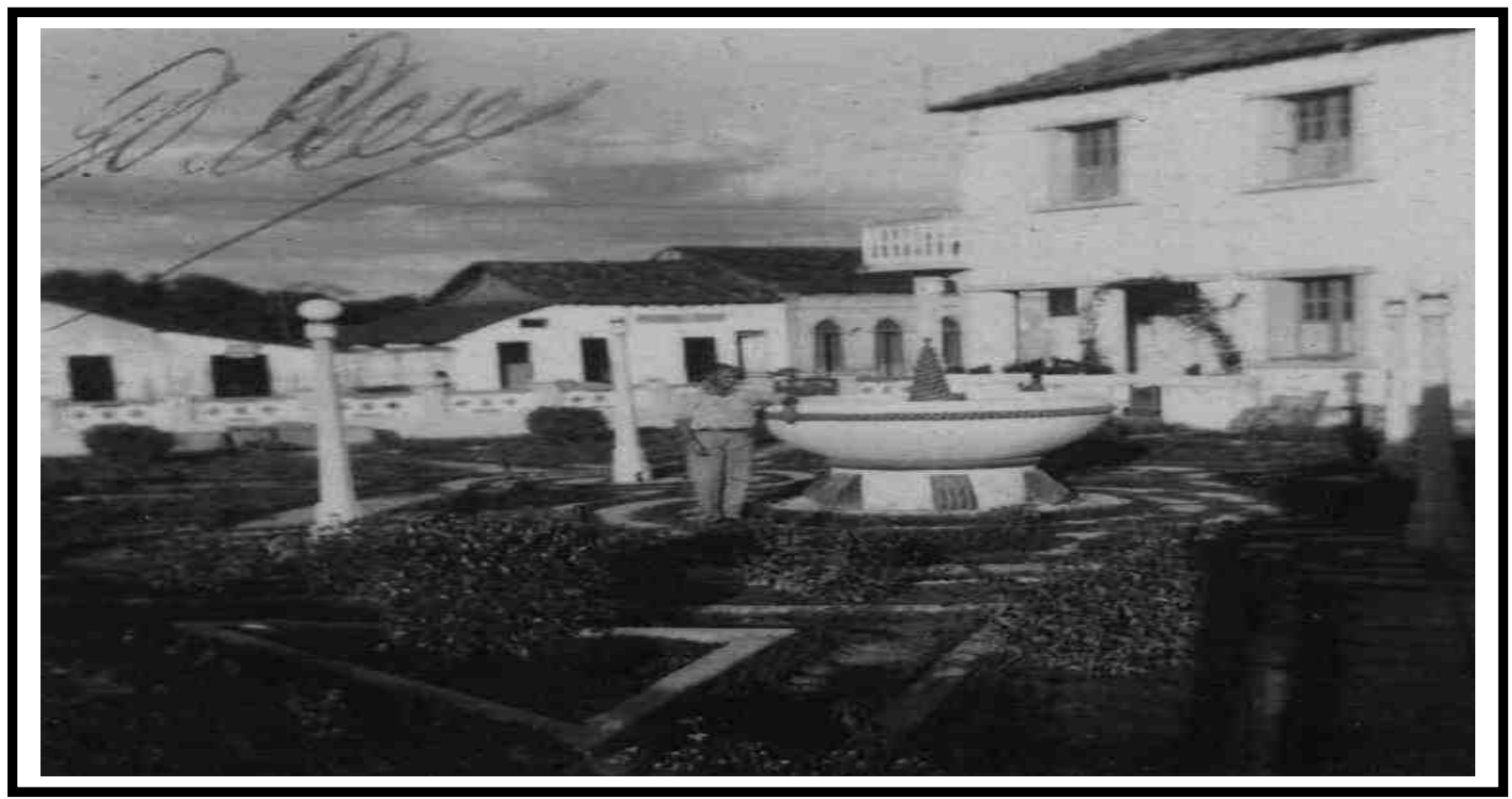

Figura 30: Residência do Governador (hoje - casa de cultura)

Foto: Acervo de Darcy Romero Derenusson

2. Escola Primária Rural (Figura 31). Conjunto de cinco escolas rurais: Possuíam sala de aula, varanda coberta e casa para professora.

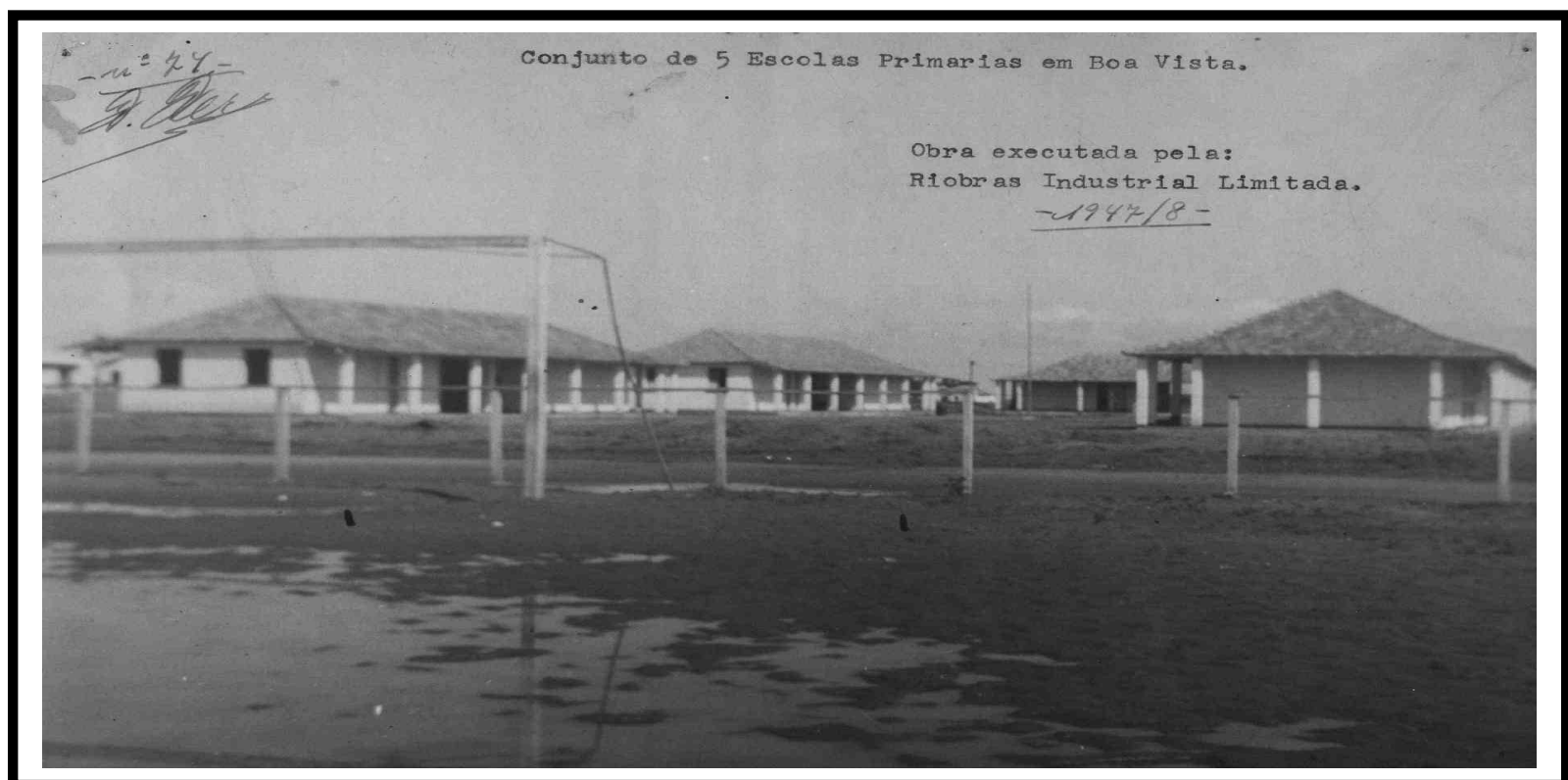

Figura 31: Escola Primária Rural

Foto: Acervo de Darcy Romero Derenusson 
3. Escolas Rurais em Mecejana (Figura 32). Foram construídas 10 escolas

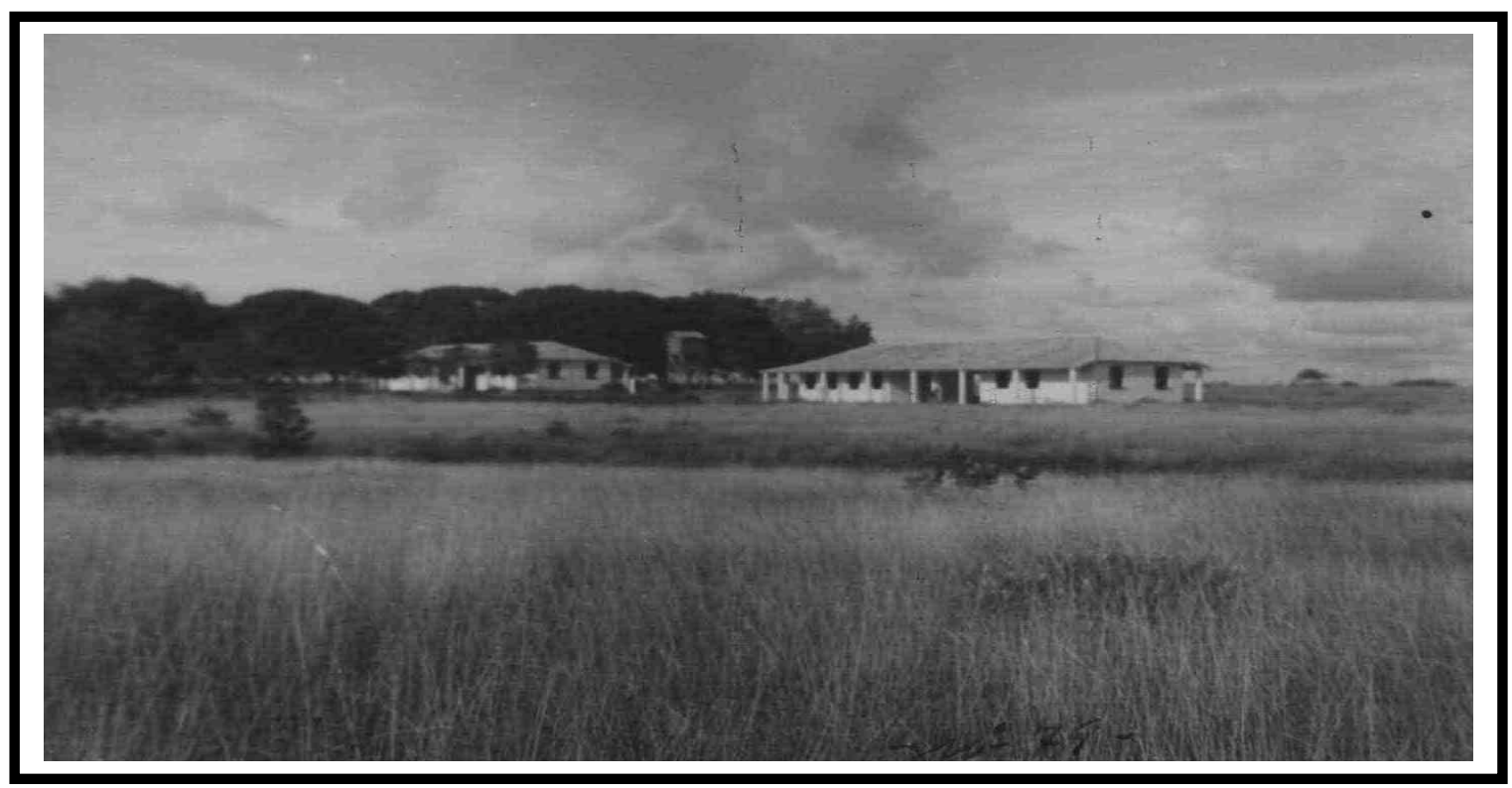

Figura 32: Escola Primária Rural em Mecejana \Déc.40 Foto: Acervo Darcy Romero Derenusson

4. Matadouro (Figura 33)

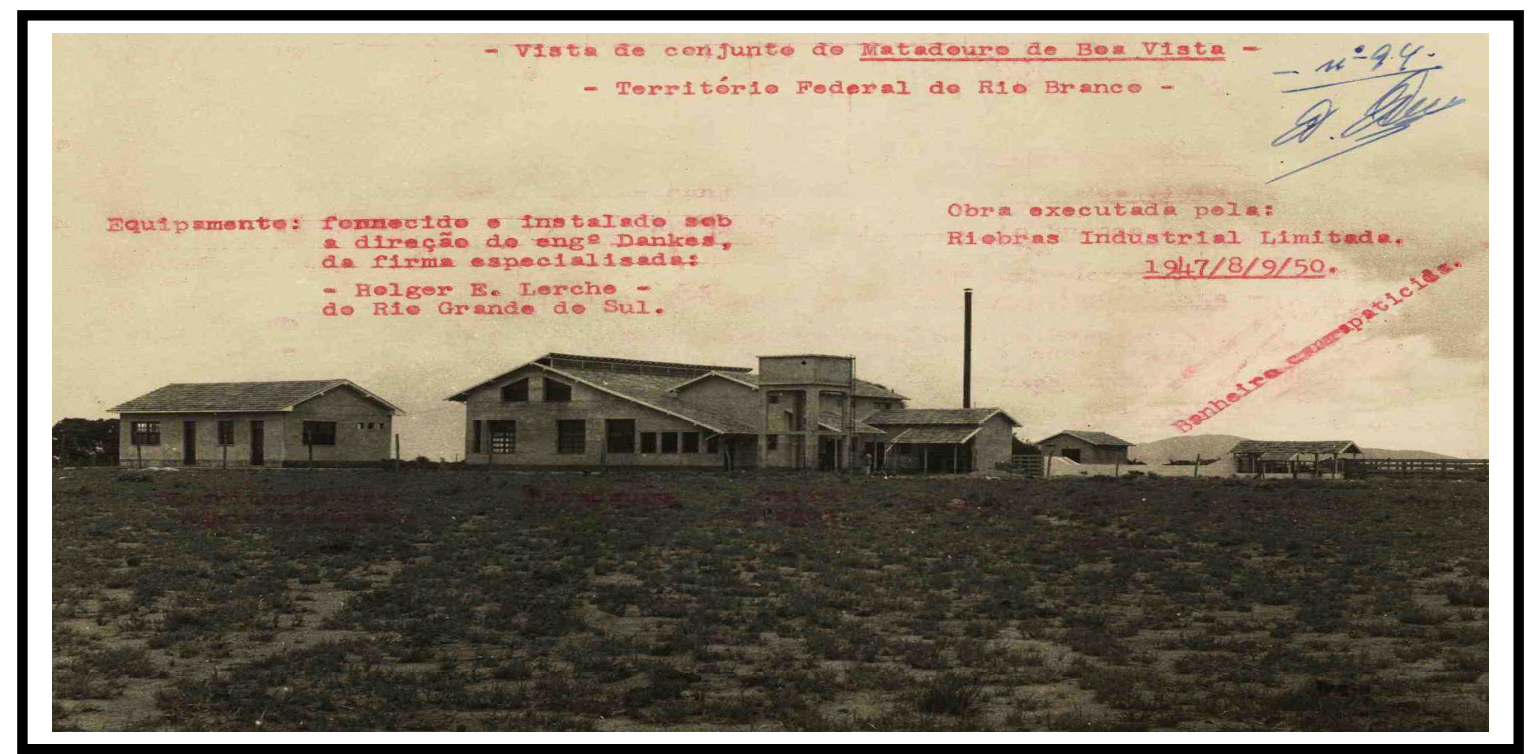

Figura 33: Matadouro Público de Boa Vista \Déc.40

Foto: Acervo Darcy Romero Derenusson 
5. Praça Capitão Clóvis (Figura 34). Praça de Esportes Capitão Clóvis, no coração de Boa Vista, até hoje está lá, com arquibancada para jogos de basquete, de vôlei e brinquedos para as crianças. Necessitando urgentemente de uma reforma e sua revitalização.

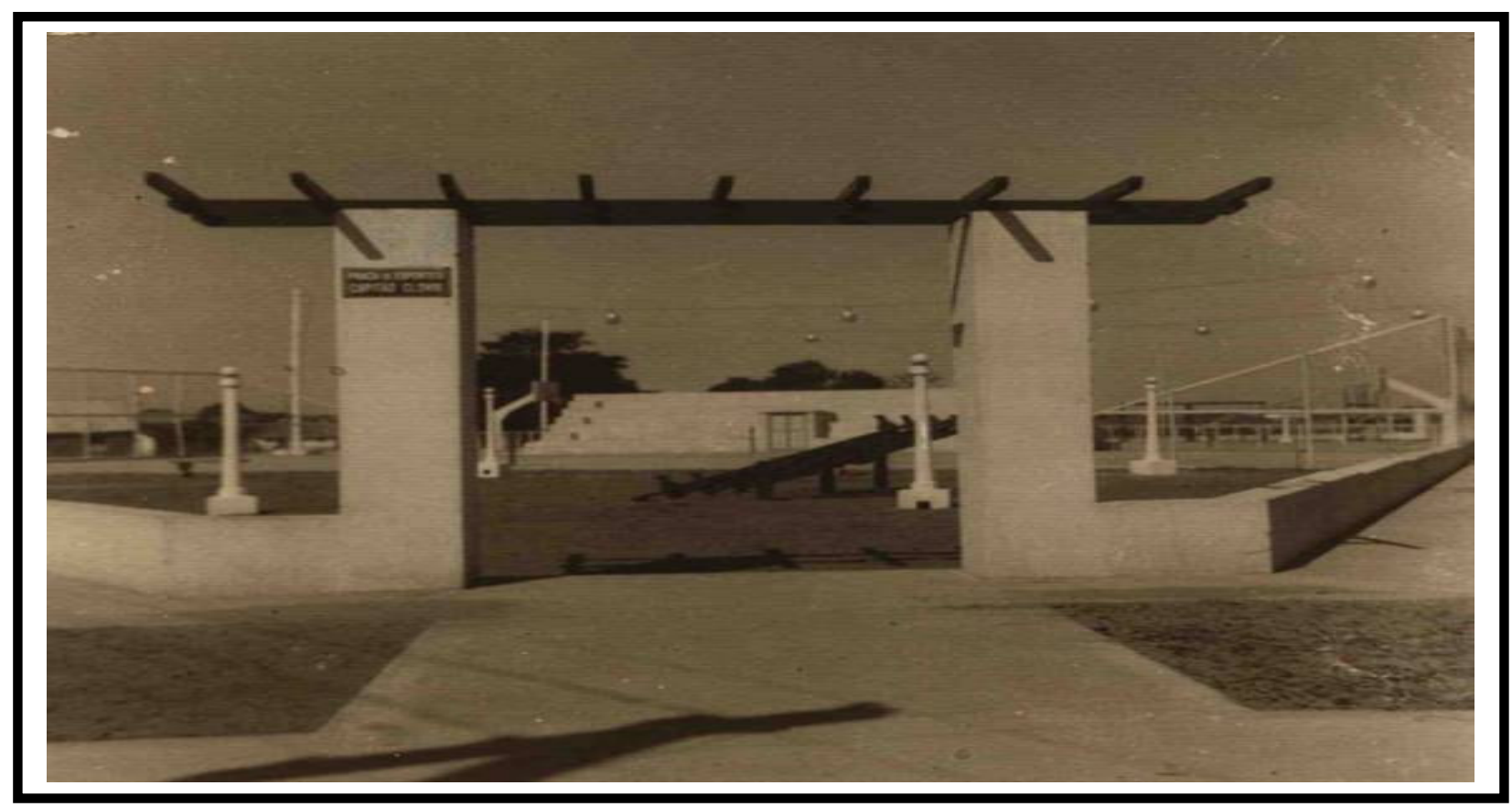

Figura 34: Praça Capitão Clovis $\backslash$ Déc.40

Foto: Acervo de Tiago Orihuela

6. Construção do Hotel Aipana Plaza (Figura 35 e 36). Projetado pelo Arquiteto Donato Melo Júnior. Sua construção levou cerca de três anos.

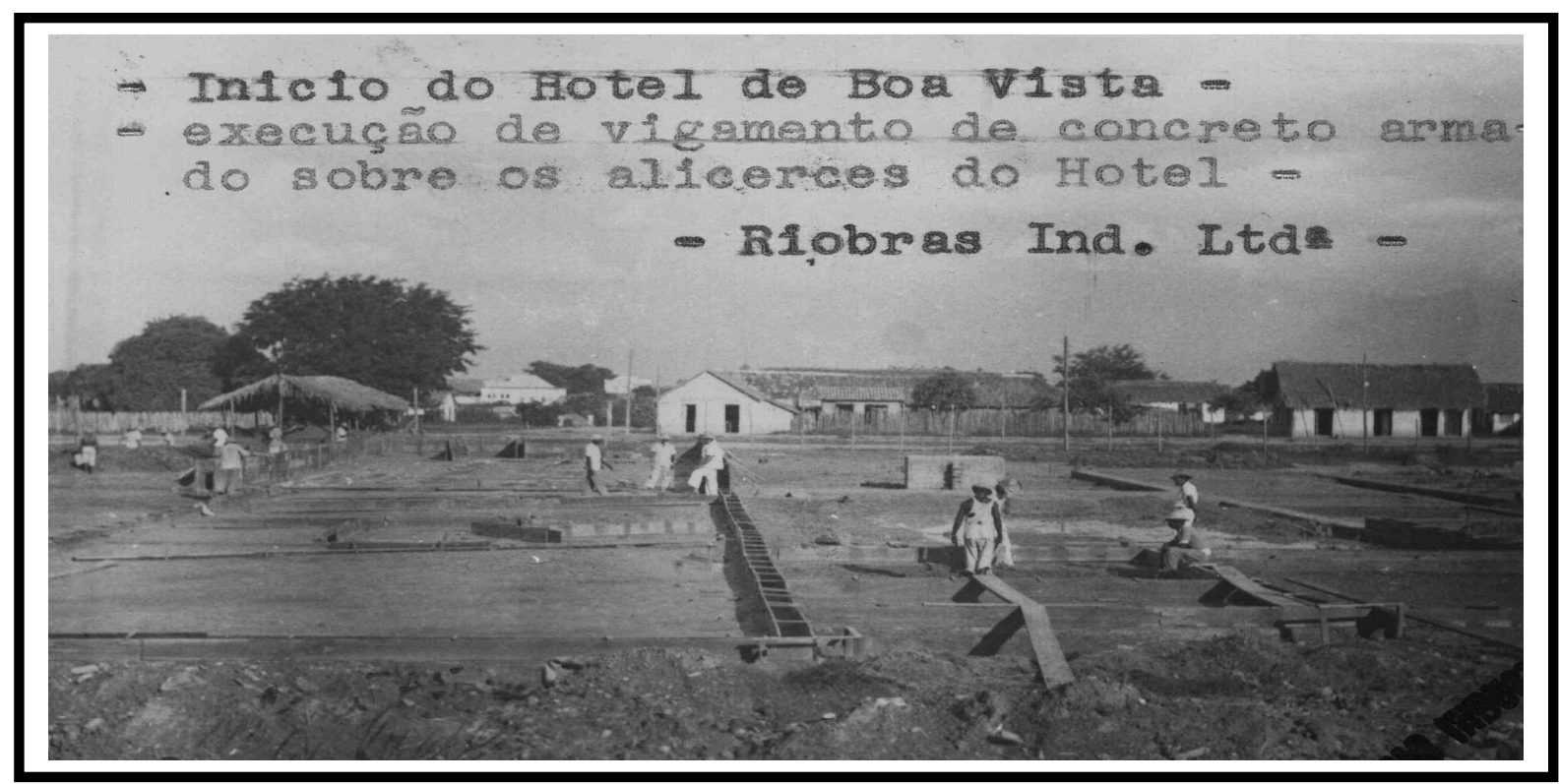

Figura 35: Construção do atual Hotel Aipana Plaza \Déc.40 (início das Obras)

Foto: Acervo de Darcy Romero Derenusson 


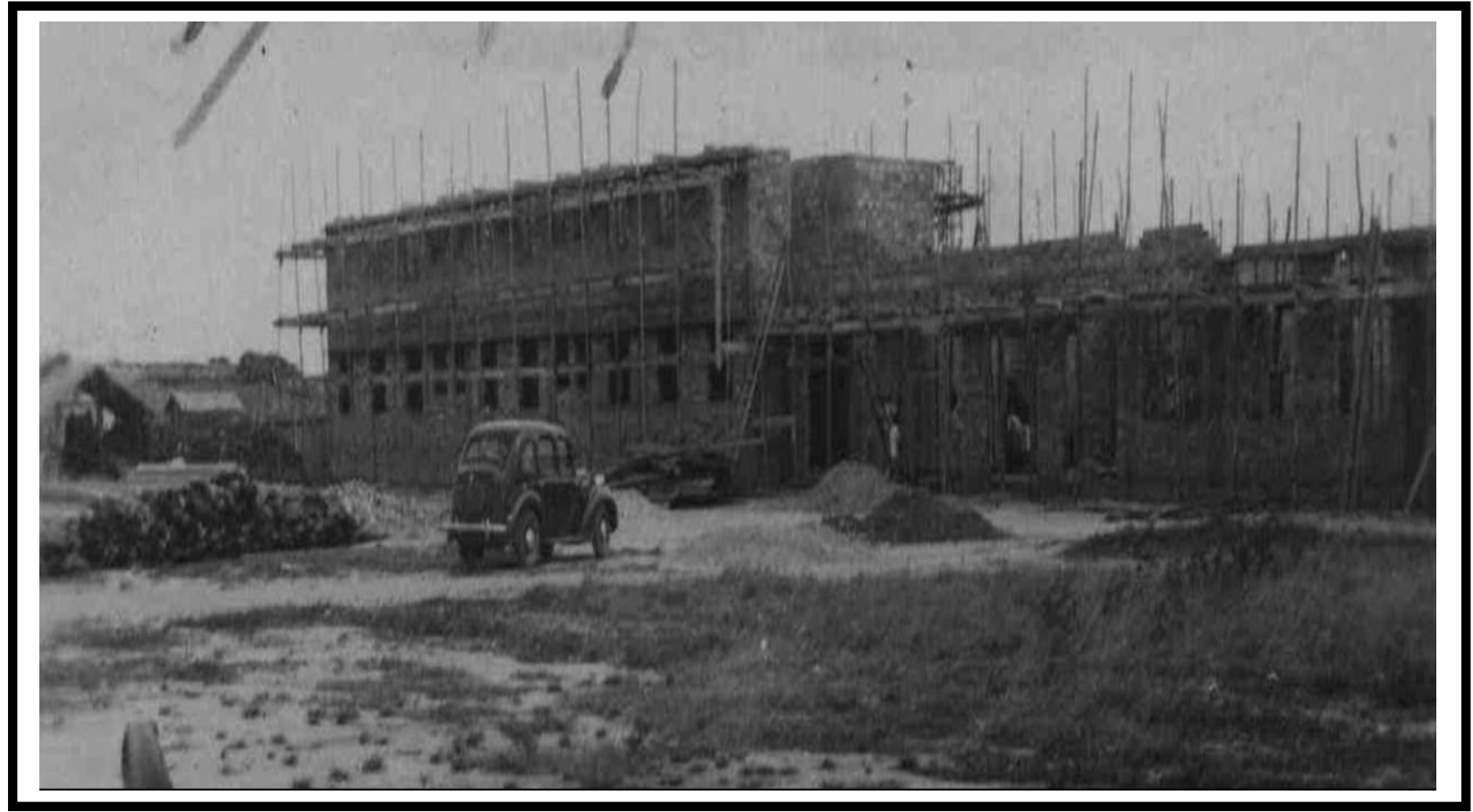

Figura 36: Obra do Hotel em novembro de 1950

Foto: Acervo de Darcy Romero Derenusson

7. Praça do Centro Cívico (Figura 37).

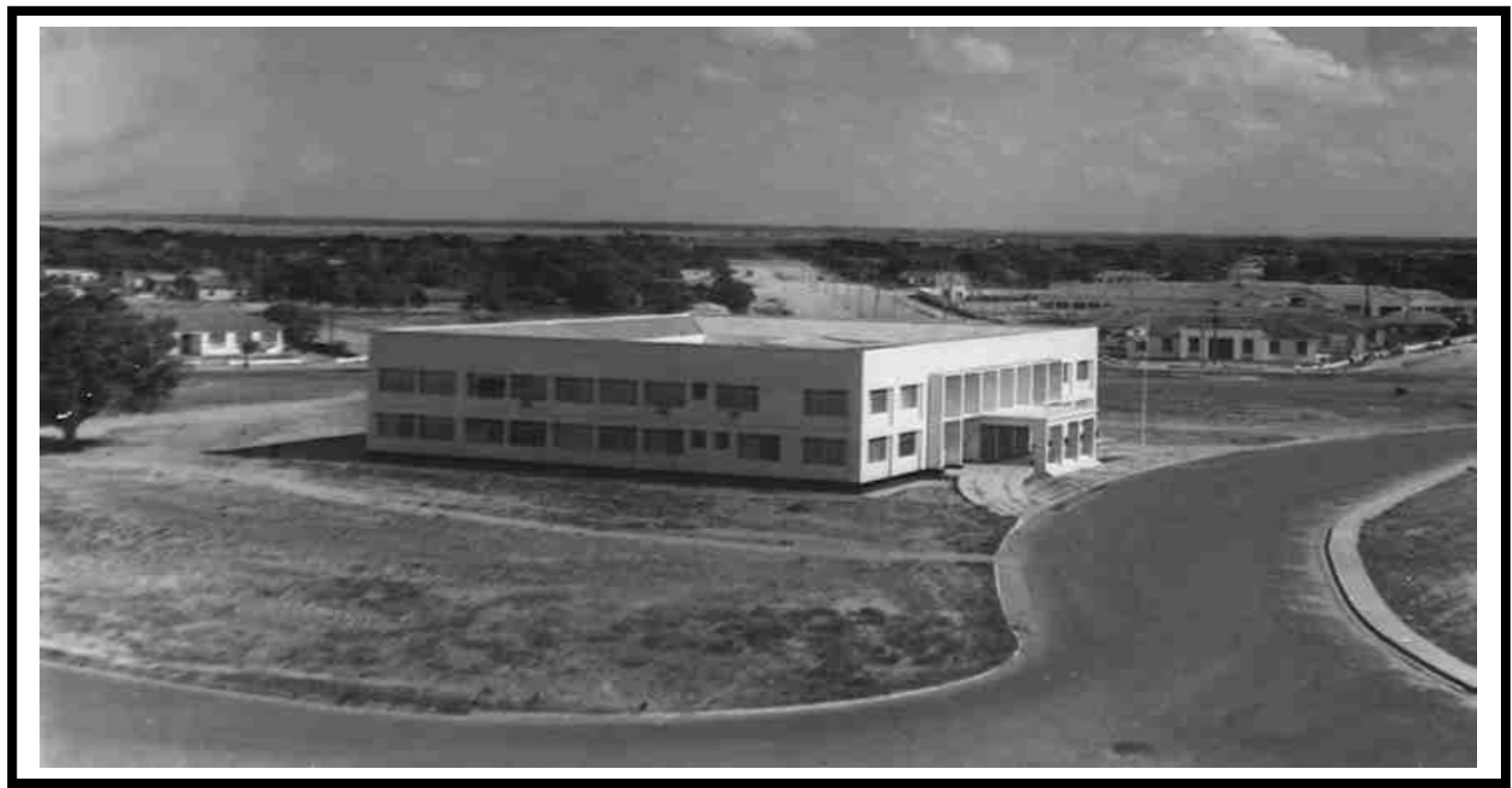

Figura 37: Praça do Centro Cívico - Palácio do Governo \Déc.40. Séc.XX

Foto: Acervo de Tiago Orihuela 
As obras iam acontecendo e o espaço destinado ao traçado sendo ocupado. O traçado compreendia a área que partia do antigo porto até a Av. Major Willams e a Av. Terêncio Lima - sua extensão, como mostra a Figura 38.

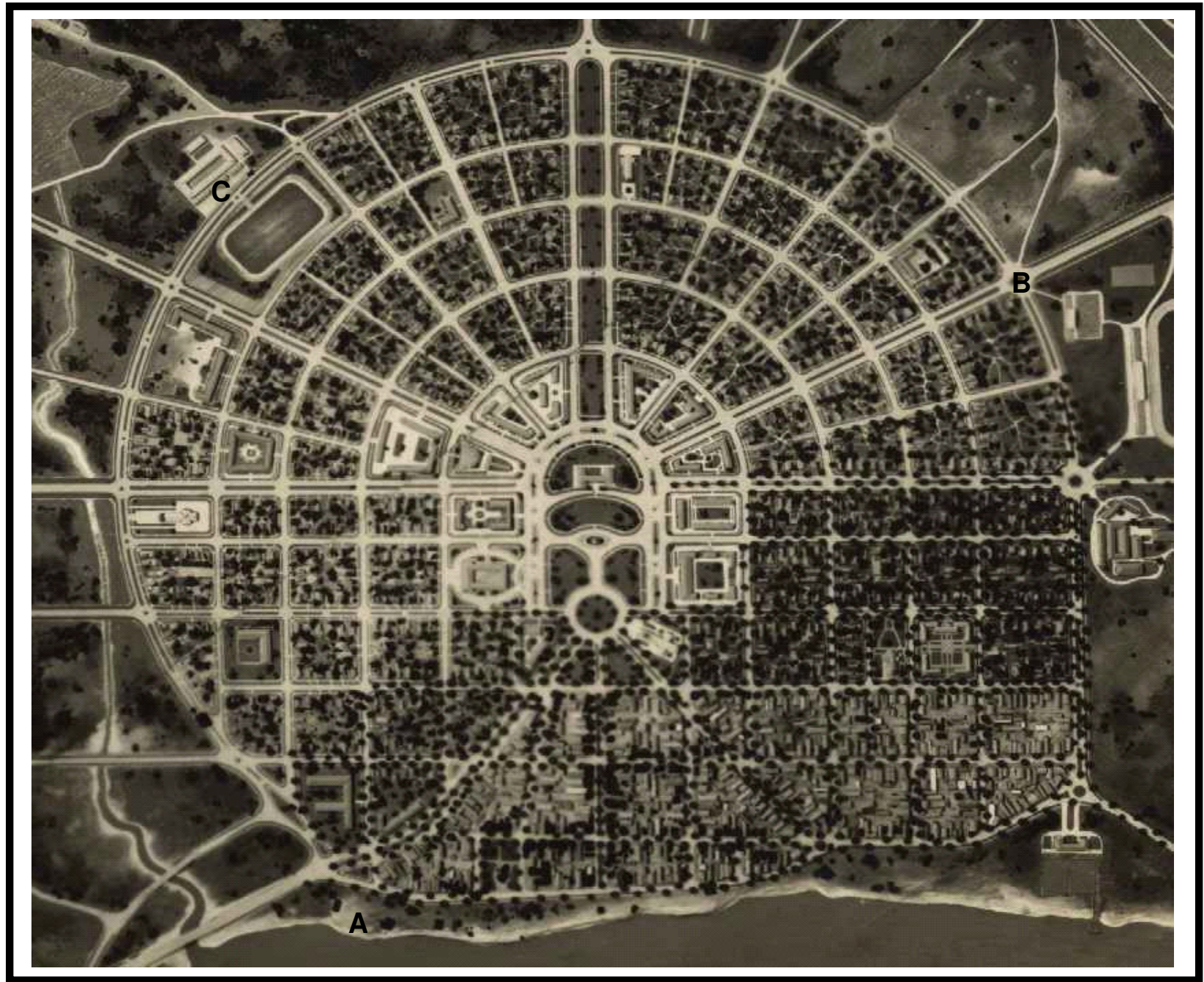

Figura 38: Limite do traçado radial concêntricol1945

Legenda: A. Porto \B. Av. Major William \C. Av. Terêncio Lima

Foto: Acervo de Darcy Romero Derenusson

Um esclarecimento adicional é que, apesar dos trabalhos realizados pelos exgovernadores e seus prefeitos, dados do Instituto Brasileiro de Geografia e Estatística - IBGE de 1981 expõe que o traçado radial concêntrico só foi ocupado em sua totalidade no final da década de 60. 
Desta maneira, a cidade aparece como um produto apropriado de forma diferenciada pelos indivíduos, em que o espaço urbano, na concepção de Carlos (2007, p. 79), é a própria reprodução da sociedade ao longo de sua formação sócioespacial. Portando o processo de produção urbana de Boa Vista deu-se a partir da produção da história de como os homens produziram e produzem as condições materiais de sua experiência.

Sendo as obras planejadas - como evidencia as figuras anteriormente expostas - a cidade de Boa Vista manteve uma simetria horizontal e vertical, porque seguia as normas de construção do Plano Urbanistico da cidade. Para Darcy Aleixo Derenusson, qualquer obra de construção destinada à habitação ou ao comércio estava condicionada ao código de construção. Ele instituía que as construções só podiam ter no máximo dois pavimentos e em terrenos de 15x40 e 20x40 metros. Isso, na opinião de Darcy A. Derenusson, explica porque Boa Vista apresenta os belos jardins e não possui favelas, como a maioria das capitais do país (JORNAL A GAZETA DE RORAIMA, 1991, p. 5).

Darcy Aleixo Derenusson, relata que o sucesso de seu trabalho quando da implantação do Plano Diretor de Urbanismo da cidade, se deve ao fato, de ter iniciado os trabalhos com as obras de rede de águas pluviais e esgotos sanitários anteriormente citadas, para depois iniciar as obras de construção propriamente ditas. Evitando, desta forma, prejuízos públicos (Infelizmente em Boa Vista, hoje, é o contrário - primeiro asfalta, depois quebra tudo para realizar os serviços de rede de águas pluviais e esgotos sanitários, causando um prejuízo enorme aos cofres público e um transtorno a população da cidade - grifo nosso) e, ao mesmo tempo, oferecendo uma melhor qualidade vida a comunidade local (JORNAL A GAZETA DE RORAIMA, 1991).

Conforme Darcy Aleixo Derenusson (1991), na década de 70 do século XX, Boa Vista chegou a ser apontada como a cidade de melhor qualidade de vida em todo o Brasil (JORNAL A GAZETA DE RORAIMA, 1991).

Passados 47 anos desde o começo da elaboração do primeiro Plano Urbanístico de Boa Vista, Darcy Aleixo Derenusson, em entrevista cedida ao Jornal A Gazeta de Roraima no ano de 1991, recomenda, ao 74 anos, que as autoridades responsáveis pela urbanização do Estado de Roraima que fossem criar novos municípios e bairros tivessem muita atenção para um detalhe fundamental: A rede de esgoto - (fato sobre o que hoje, em pleno século XXI, sentimos um descaso 
das autoridades locais, que dizem que fazem - no discurso - quando, na prática, acontece totalmente contrário, vergonhoso...sem falar na criação de municípios, que são criados sem um Plano Diretor estratégico que possa facilitar a administração pública - grifo nossa). Esse serviço, diz o engenheiro, é imprescindível para favorecer uma qualidade de vida para os cidatinos (JORNAL A GAZETA DE RORAIMA, 1991).

Na verdade, segundo Darcy A. Derenusson (1991), foi isso que tornou Boa Vista uma cidade sadia e agradável. O núcleo da capital planejada em 1944 contou com um sistema de abastecimento de água e rede de esgoto de águas pluviais e sanitárias. Conseqüentemente, a comunidade usufruiu de uma qualidade de vida melhor (JORNAL A GAZETA DE RORAIMA, 1991).

Mediante as intervenções espaciais, supracitadas, somos mais uma vez chamados a refletir sobre a produção do espaço para entendermos as diversas ações e intencionalidades (im) postas no espaço urbano de Boa Vista.

Devemos ter em mente que a sociedade só pode ser definida por meio do espaço, uma vez que o espaço é o resultado da produção, uma conseqüência de sua história, ou seja, da história dos processos produtivos impostos ao espaço pela a sociedade [...], sendo que o espaço constitui uma realidade objetiva, um produto social em permanente processo de transformação (SANTOS, 1985, p. 49).

As categorias forma, função, estrutura e processo são visíveis nesse processo, uma vez que nos dar uma base teórica e metodológica para discutir os fenômenos espaciais em sua totalidade.

A inserção das formas espaciais no espaço urbano de Boa Vista (residências, edifícios públicos - escola, posto de saúde entre outros) tem um significado social, uma vez que ela está diretamente relacionada com a função, que é a atividade elementar de que a forma espacial se reveste, isto é, as funções estão cristalizadas nas formas e estas, por sua vez, são criadas a partir de uma ou de várias funções. Todavia, forma e função não podem estar separadas da estrutura, pois esta nada mais é do que a inter-relação das diversas partes que compõe o todo (SANTOS, 1985, p. 49-53).

Segundo Trindade Jr (1997, p. 08), é fundamental que se entenda, também, a estrutura social de cada período histórico para que se tenha a idéia das transformações das formas ou mesmo de sua inércia. A estrutura, para o autor, em qualquer momento, atribui valores e funções determinadas às formas do espaço. 
Dentro desses três elementos - forma, função e estrutura - sobressai ainda o processo que é uma ação contínua que se desenvolve rumo a um resultado qualquer. Por isso, para Trindade Jr (1997, p. 8) "envolve conceitos de tempo, continuidade e mudança [...], tornando-se uma propriedade entre forma, função e estrutura". Pois é ele, - processo-, que indica o movimento do passado ao presente (SANTOS, 1985, p. 54).

Desta maneira, é necessário pensar a dinâmica de produção do espaço urbano de Boa Vista, a partir dessas categorias. Pois, como assevera o professor Milton Santos (1985, p. 53)

Quando se estuda a organização espacial, estes conceitos são necessários para explicar como o espaço social está estruturado, como os homens organizam a sua sociedade no espaço e como a concepção e o uso que o homem faz do espaço sofrem mudanças. A acumulação do tempo histórico permite-nos compreender a atual organização espacial. 


\title{
2.2.3 Considerações sobre o traçado
}

\author{
Projetada com expiração na cidade de Belo Horizonte ${ }^{19}$, Boa Vista seguiu os \\ mesmos padrões do traçado urbano da capital de Minas Gerais, pois apresentava \\ subdivisões em zona urbana, suburbana e sítios. \\ Desta maneira, sua familiaridade com o plano de Belo Horizonte está na \\ integração das funções urbanas com suas radiais convergindo para o Centro \\ Administrativo ou "Praça dos Três Poderes" - Executivo, Legislativo e Judiciário -; na \\ importância das áreas verdes - Praças e jardins -; nos imperativos de higienização - \\ saneamento básico -; e na circulação com suas largas avenidas.
}

${ }_{19}$ Projetada em 1895 e inaugurada em 12 de dezembro de 1897 como capital administrativa do Estado de Minas Gerais, Belo Horizonte nasce moderna em sua concepção e traçado [...] Erguida sobre o Arraial de Belo Horizonte, antigo Curral d'El Rey, a cidade é projetada pela Comissão Constitutiva da Nova Capital, dirigida pelo engenheiro politécnico Aarão Reis (1853 - 1936). A escolha do sítio se dá pela sua proximidade do centro geográfico do Estado e de sua fisionomia natural, espécie de anfiteatro localizado na parte mais baixa de uma encosta da Serra do Curral. A formação positivista de Aarão Reis reverbera numa concepção de espaço urbano apoiada nos avanços da ciência e da técnica. $O$ desenho da cidade obedece às leis de ordenamento e simetria, às necessidades de integração das funções urbanas, assim como aos imperativos modernos da circulação e da higienização. [...] "Foi organizada a planta da futura cidade dispondo-se na parte central, no local do antigo arraial, a área urbana de 8.815 .382 metros quadrados, dividida em quarteirões de $120 \times 120$ metros, que se cruzam em ângulos retos e por algumas avenidas que os cortam em ângulos de 45 graus. Às ruas fiz dar a largura de 20 metros, necessária para a conveniente arborização, a livre circulação dos veículos (...). Às avenidas fixei a largura de 35 metros, suficiente para dar-lhes a beleza e o conforto que deverão, no futuro, propiciar à população. Apenas a uma das avenidas - que corta a zona urbana de norte a sul, e que é destinada à ligação dos bairros opostos - dei a largura de 50 metros, para constituí-la em centro obrigado da cidade e, assim, forçar a população, quanto possível, a ir-se desenvolvendo do centro para periferia, como convém à economia municipal e à manutenção da higiêne sanitária (...). Essa zona urbana é delimitada e separada da suburbana por uma avenida de contorno, que facilitará a conveniente distribuição dos impostos locais..."[...] A nova capital inspira-se em alguns modelos de cidades estrangeiras, por exemplo, no plano da cidade de Washington, na Paris reformada pelo barão Haussmann (1809 1891) e sobretudo no plano de La Plata (1882), Argentina, com o qual compartilha a mesma concepção urbanística. Como La Plata, Belo Horizonte apresenta uma malha urbana ortogonal cortada por diagonais e "fechada" por um anel circular, a avenida do Contorno. A importância das áreas verdes e os quarteirões com 120 metros são outras idéias fornecidas pelo exemplo argentino. Da experiência francesa, por sua vez, Aarão Reis aproveita os bulevares arborizados e reafirma o lugar proeminente dos parques e praças na vida urbana. Não por acaso um de seus colaboradores é o arquiteto e paisagista Paul Villon, que havia trabalhado com Haussman. Em Belo Horizonte, Villon participa do projeto do parque Municipal e dos jardins do Palácio da Liberdade. A capital está dividida em três zonas: urbana, suburbana e sítios. A zona urbana - cujo núcleo é definido pelo parque Municipal - compreende o centro administrativo, o Palácio do Governo e as secretarias de Estado. Aí estão localizados ainda o bairro dos funcionários, o bairro do comércio (praça do Mercado e da Estação), os Palácios do Congresso e da Justiça. Na zona suburbana, de geometria mais flexível e menos sistematizada, localizam-se o hipódromo, o cemitério e o reservatório de água. Os sítios correspondem às áreas semi-rurais, dotadas de pequenas propriedades e responsáveis pelo abastecimento da cidade [...] Maiores informações Consultar: Enciclopédia Itaú Cultural\Artes Visual: Site: www.itaucultural.org.br 
Um dado a ser acrescentado é que o modelo de cidades-jardim com radiais convergindo para um núcleo central tem sua origem na proposta de Ebenezer Howard para as cidades da Inglaterra em 1898. O modelo surgiu no final do século XIX, transformando-se no produto urbanístico mais bem sucedido da discussão que se promovia à época sobre os prejuízos causados à vida urbana pelo acelerado processo de industrialização nas cidades inglesas.

Howard (1996, p. 11-118) ${ }^{20}$ a idealizou usando esquemas das cidades ideais do Renascimento e do Barroco. Por isso, os esquemas das cidades-jardim são fortemente radiais concêntricos, assim como o centro primário e os subcentros. Usou, além disso, a boa e velha tradição européia quando promoveu os centros das cidades-jardim como centros comunitários e culturais, como lugares predestinados para serviços coletivos e atividades de vizinhança.

Acreditava que os conjuntos habitacionais junto às fábricas e implantados no campo poderiam ter um efeito saudável sobre os trabalhadores e, conseqüentemente, retornaria em benefícios para a indústria.

A cidade é apresentada por meio de diagramas [...] os diagramas mostram uma cidade circular divididas em seis setores (Figura 39 e 40). Estes são delimitados por seis bulevares arborizados com $36 \mathrm{~m}$ de larguras, que se irradiam no Parque Central e se estendem até o perímetro externo, circundado pela ferrovia que, após envolve a cidade, transforma-se em estrada de penetração no ambiente rural. Completam a estrutura viária da Cidade-Jardim, cinco avenidas, também arborizada, concêntricas ao Parque Central. A terceira delas, A Grande Avenida, possui largura de $128 \mathrm{~m}$ por $4,8 \mathrm{~km}$ de extensão e é proposta como um grande parque, lembrando a Avenue Foch de paris com seus 120 metros de largura. Estes bulevares, avenidas e a Grande Avenida mostram que Howard, antítese do pensamento de Haussmann ${ }^{21}$, não deixava de estar atento aos espaços viários obtidos na remodelação de Paris, dando-lhe, no entanto, novos usos e característica (HOWARD, 1996, p. 41).

${ }^{20}$ Maiores informações Consultar: HOWARD, Ebênezer.Cidades-Jardins de Amanhã. Tradução: Marcos Aurélio Lagonegro.São Paulo-Hucitec.1996.

${ }^{21}$ [...] Em 1853, o Barão de Haussman, o então prefeito de Paris, propõe um plano de adaptação e reordenamento territorial para a cidade, o qual enfatizava questões de circulação, insalubridade e degradação espacial [...] redesenha Paris colocando em evidencia alguns elementos morfológicos, que conferem unidade e qualidade formal a cidade, como: o traçado das avenidas alternadas de Bulevares, o dinamismo das vias convergindo para praças [...] estas observações morfológicas, mais tarde, viriam a caracterizar o plano e a própria leitura de Paris. Consultar: SALLEM, Ângela Leitão. Morfologia e desenho urbano na configuração da cidade planejada: O caso de Curitiba. Dissertação de Mestrado. Pontifica Universidade do Paraná. Programa de Pós-Graduação em Gestão Urbana. 2006. 


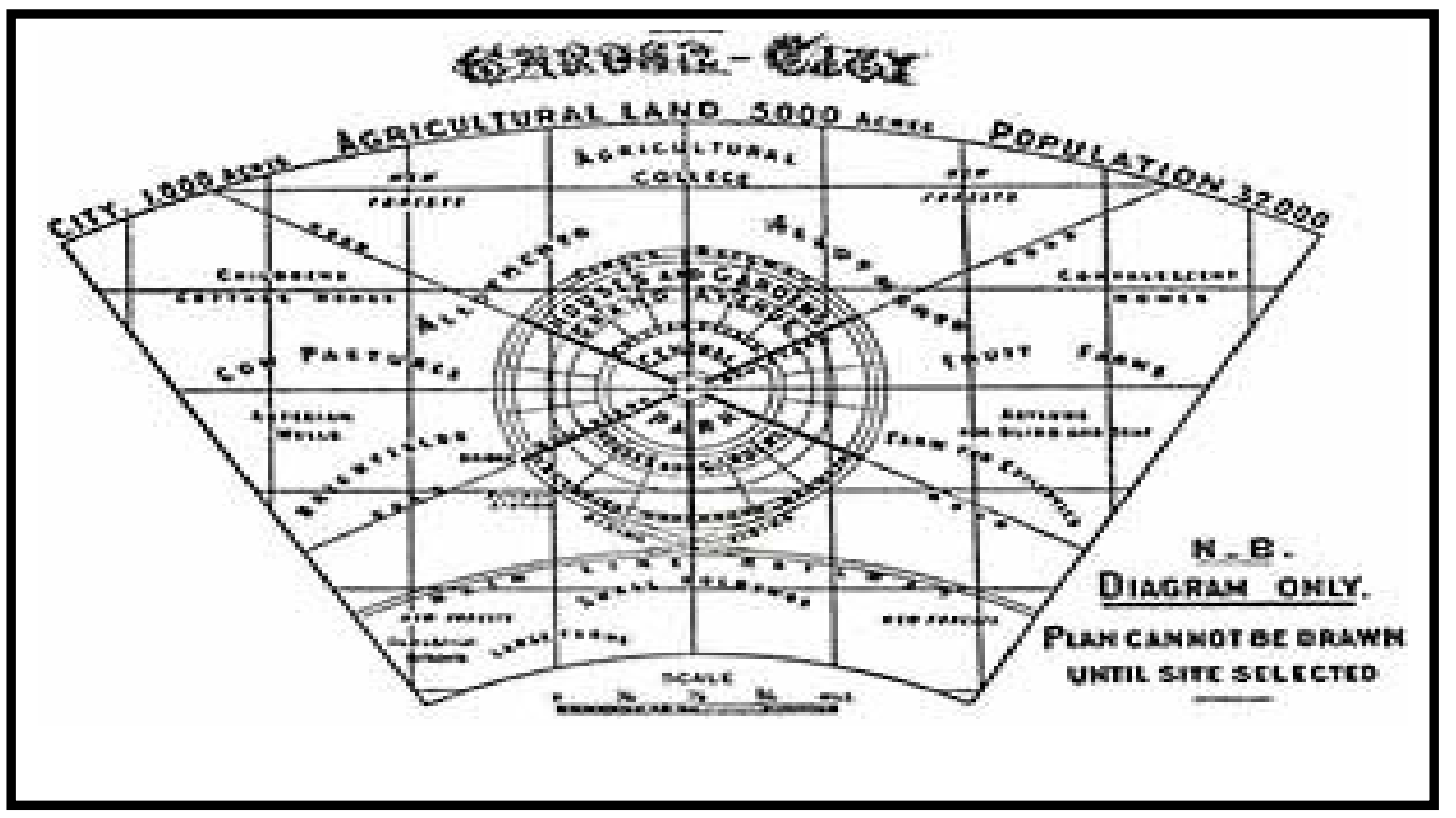

Figura 39: Diagrama de Howard \Planejamento (a cidade não podia ser desenhada até ser selecionado o local)

Foto: Acervo de Ebênezer Howard, 1996.

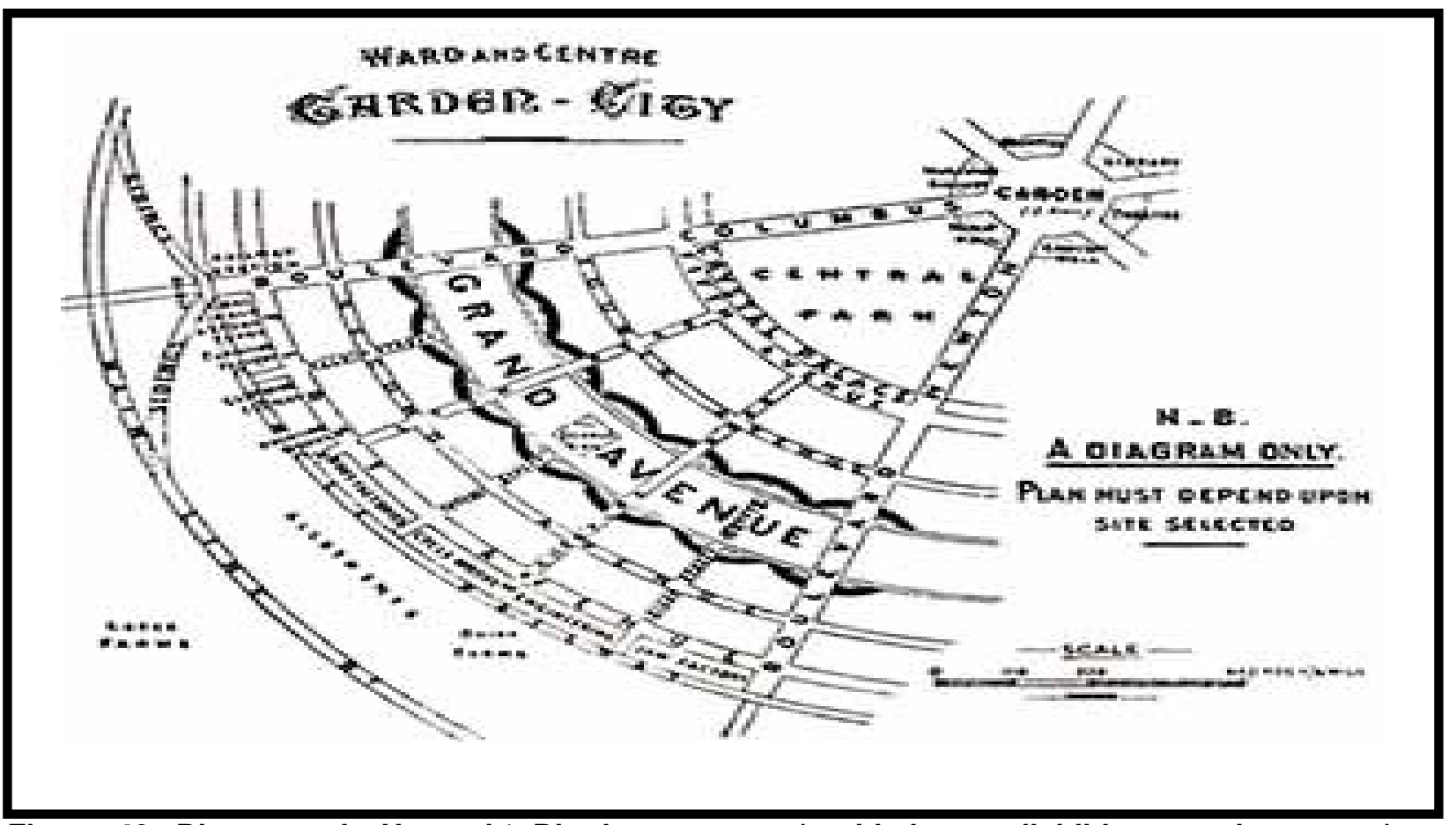

Figura 40: Diagrama de Howard \Distrito e centro (a cidade era dividida em seis setores) Foto: Acervo de Ebênezer Howard, 1996. 
O desenho das Cidades-Jardins teve como fonte inspiradora as experiências de implantação de comunidades planejadas do século XIX para serem autoplanejadas, como os empreendimentos de indústrias preocupados com a qualidade de vida de seus empregados.

De acordo com Choay (1998), esses modelos pré-urbanos do século XIX são criticados por sociólogos, pois "a cidade não era vista como um processo, mas como um objeto reprodutível, extraída da temporalidade concreta, portanto, utópica, apesar das preocupações realistas socioeconômicas do autor da Cidade-Jardim". Segundo o autor, este modelo é culturalista ${ }^{22}$, pois prevalece a visão cultural sobre a racionalista progressista, ou seja, as necessidades espirituais e artísticas representadas por espaços com formas menos rigorosas com particularidades e variedades prevalecem sobre a lógica racional dos espaços aplicados para qualquer lugar do modelo progressista.

Outra grande critica ao modelo de Cidade-Jardim sob o ponto de vista da sustentabiliade é o efeito da suburbanização que este causou, ou seja, a expansão urbana com baixas densidades que ocupam terras agricultáveis. Este efeito é melhor percebido nos Estados Unidos da América - EUA, e hoje no Brasil é representado pela expansão de condomínios irregulares sem infra-estrutura econômica e preocupações ecológicas ${ }^{23}$.

Para Geddes(1994, p. 229), Howard (1996) resumia a idéia de cidade-jardim, como sendo:

\begin{abstract}
Uma cidade planejada para a indústria e a vida saudável; em uma dimensão que permita uma plena medida da vida social, mas não exagerada; rodeada por um permanente cinturão de área rural, de propriedade pública ou mantida em custodia para a comunidade.
\end{abstract}

\footnotetext{
${ }^{22}$ O modelo culturalista, não é capaz de analisar e formular a lógica conflitante do desenvolvimento urbano, não consegue tão pouco propor alternativas que não sejam aquelas que, supostamente, estariam acima dos interesses sociais em jogo: a mera reconstrução física do espaço. Nesse ponto ele se torna utópico, na medida em que, ingenuamente, propõe a correção física do espaço, da mesma forma, mas em versão diferente, que o urbanismo das cidades - jardins de Howard (embora, nesse caso, propusessem a propriedade pública ao solo como antídoto aos ganhos especulativo). (CAMPOS FILHO, 2001, p. 12).

${ }^{23}$ ANDRADE, Liza Maria de. O conceito de cidade - jardim: uma adaptação para as cidades sustentáveis. Arquitextos\042.01. Endereço Eletrônico: www.vitruvius.com.br.
} 
Partindo-se da idéia de Howard sobre o modelo de cidade-jardim e comparando-o com o traçado urbano de Boa Vista, percebe-se que suas semelhanças estão nas radiais concêntricas, nas áreas verdes e no núcleo central, no qual estão situados os edifícios públicos.

Reforçando o exposto, segundo Pavani \& Moura (2007, p. 30) "o projeto estabelecia que o poder Executivo, Legislativo e Judiciário originaria a parte central do leque da cidade, onde seria instalado o núcleo administrativo de Roraima, sendo o centro ocupado pelo Palácio do Governo" (Figura 41).

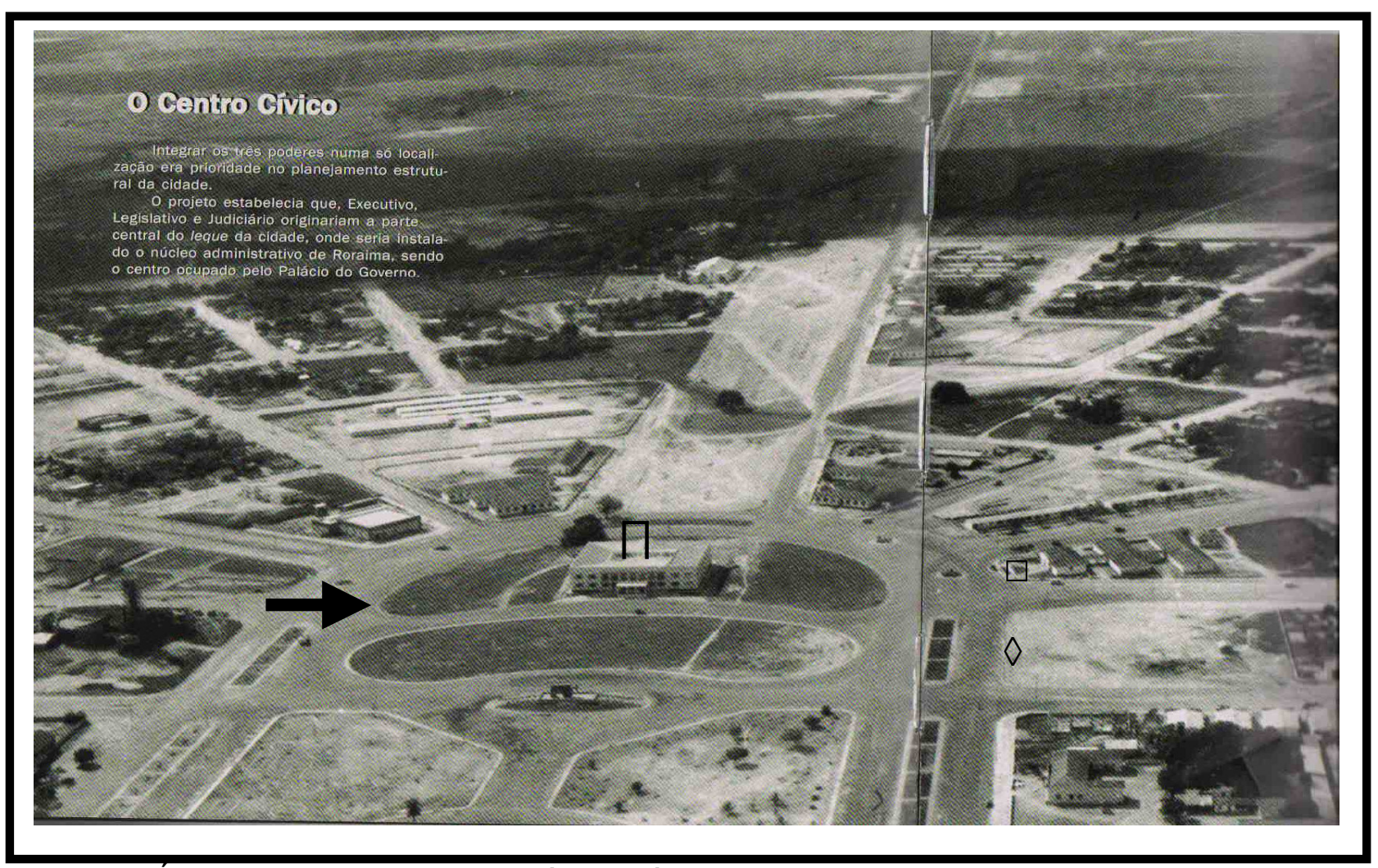

Figura 41: Área Central de Boa Vista \Déc. 70 Séc. XX

Legenda: Locais destinados as sedes do $\Pi$ Poder Executivo $\backslash \diamond$ Poder Legislativo $\backslash \square$ Poder Judiciário $\backslash$ $\Rightarrow$ Área Central

Fonte: Pavani \& Moural2007 
Saindo da Praça Circular, temos as 10 (dez) radiais, que irradiam e estendem-se para o perímetro externo do plano original da cidade, são elas:

1. Av. Ville Roy;

2. Av. Capitão Júlio Bezerra;

3. Rua Professor Agnelo Bittencourt;

4. Av. Capitão Êne Garcez;

5. Av. Mario Homem de Melo;

6. Av. Glaycon de Paiva;

7. Av. Nossa Senhora da Consolata;

8. Av. Benjamim Constant;

9. Av. Sylvio Lofêgo Botelho; e

10. Av. João Pereira de Melo;

As radiais aqui mencionadas são as que partem da Praça Circular ou Bola, como é conhecida pelos os cidatinos, e, que apresentam características sócioespaciais diferenciadas como, se evidencia no Mapa 7.

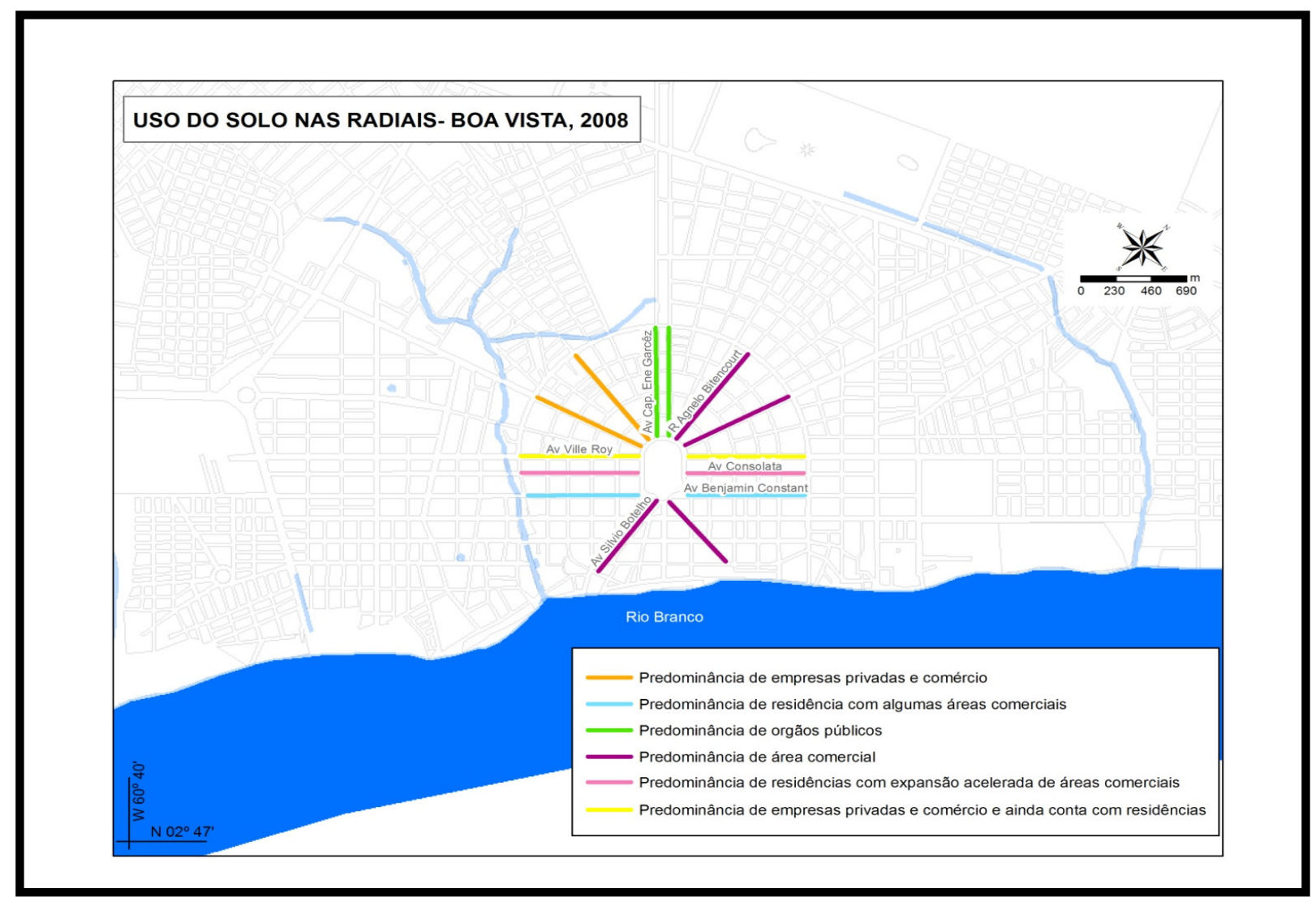

Mapa 7: Radiais do traçado urbano que partem do centro $\backslash 2008$

Fonte: IBAM, 2004

Organização: Antonio T. R. Veras; João T. R. Pereira e Laticia Palazzi 
Nas radiais, existe canteiro central elou praças ao longo de sua extensão. As casas apresentam lotes amplos e independentes. Na sua maior parte, são construídas em anéis concêntricos com face para as várias avenidas (vias circulares) ou em frente às radiais que convergem para o centro da cidade.

Quanto à arquitetura e ao desenho que exibem as casas, algumas delas possuem jardins comuns e são arborizadas com árvores frutíferas; fato histórico que merece atenção dos gestores públicos, diante do perigo que poderia causar aos transeuntes e da possível sujeira nas ruas. As casas são de alvenaria, porém, constata-se a presença de casas de madeira e mistas (madeira e alvenaria) em pequena quantidade.

Conforme Pavani \& Moura (2007, p. 36)

\begin{abstract}
A área central de Boa Vista possui um sistema viário composto por avenidas de três ou quatro faixas de rolamento e canteiros centrais generosos, possibilitando a arborização das vias que formam passeios confortáveis para pedestre. A formação desse sistema compreende em vias estruturais, vias principais e vias coletoras, valorizando o deslocamento e a distribuição da malha viária para os bairros, já prevendo a expansão urbana.
\end{abstract}

Em relação às limitações do modelo de Howard (1996), e de Boa Vista, Campos Filho (2001, p. 90) comenta que esse modelo estava pautado em soluções radioconcêntricas e foram dominantes até a década de 50 . Todavia as soluções pouco a pouco foram colocadas em xeque, devido ao crescente aumento de veículos automotores nas rodovias, que exigiam um espaço viário cada vez maior, fase aos constantes congestionamento no sistema viário radioconcêntrico.

Este fato é presenciado na cidade de Boa vista quando, em horário de pico, a área central fica congestionada, tendo em vista o crescente aumento de veículos automotores e a ausência de espaços viários que facilitem a conexão para as outras zonas da cidade.

Para amenizar o problema, o departamento de trânsito municipal implantou diversas rotatórias nas principais avenidas da cidade. A esse projeto foram incorporados jardins que compõem a urbanização e o paisagismo implantados nos canteiros centrais das vias (PAVANI \& MOURA, 2007, p. 38) (Figura 42). 


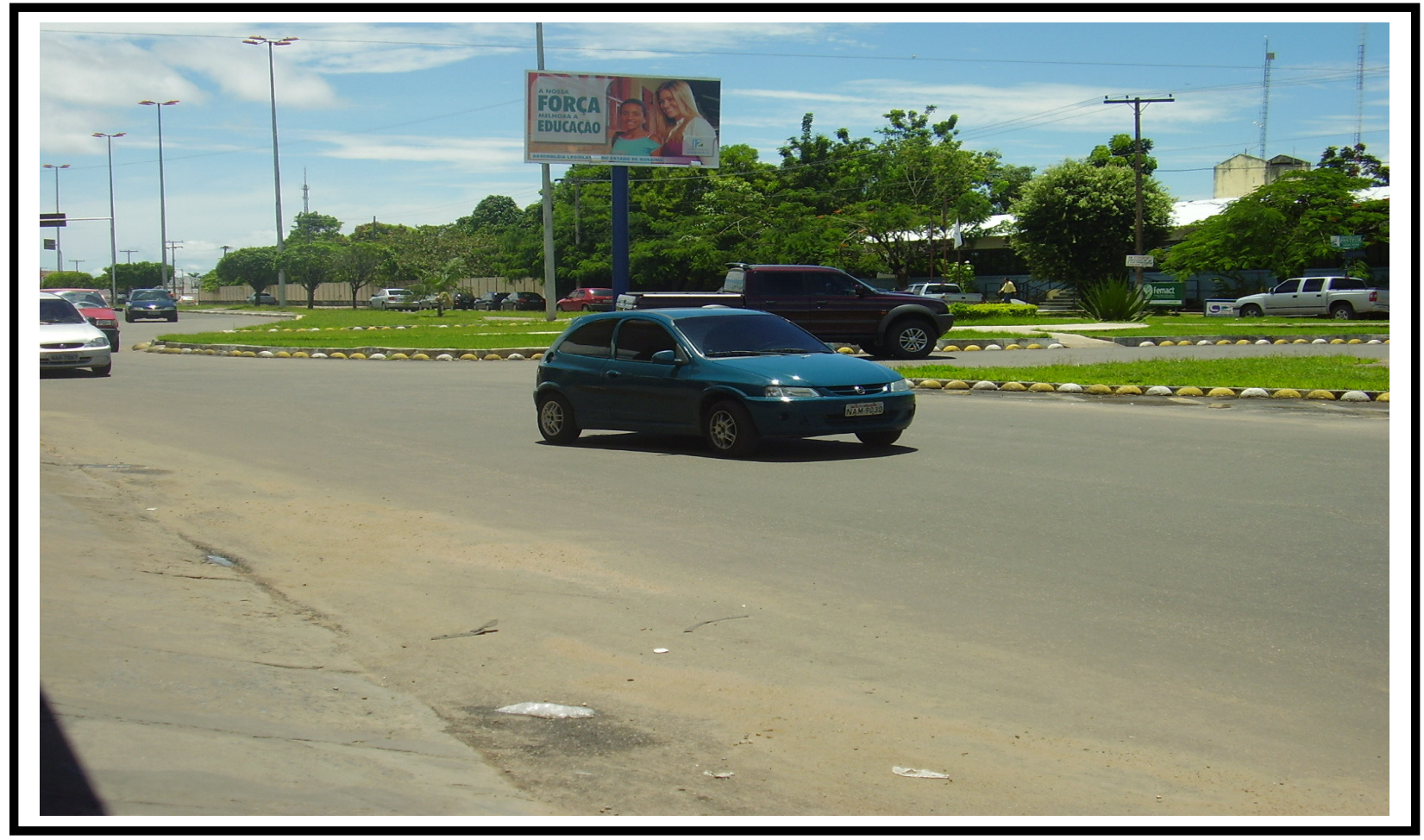

Figura 42: Rotatória no cruzamento da Avenida Ville Roy com Avenida Santos Dumont $\backslash 2008$ Foto: Acervo de Laura Patrícia Lopes Veras

Reforçando as considerações supracitadas, Barros (1995) expõe que o plano urbanístico elaborado pelo engenheiro civil Darcy Aleixo Derenusson assemelha-se, em linhas gerais, ao modelo de Howard - Cidades-Jardim.

\section{Para o geógrafo Barros (1995)}

Da ampla praça circular, partem as radiais para o Norte, Oeste e Sul, extremamente largas e com ampla área para construção de enormes jardins centrais (Figura 43). Da praça circular reuniu os edifícios públicos, braços administrativos dos Ministérios da República, conferindo-lhe monumentalidade derivada da burocracia do estado federal, não de religião (templo) ou de construções privadas (de comércio, por exemplo). Sem marcos de relevo do solo, ou de área de construções verticais, a antena estatal da empresa telefônica atua como signo visual de orientação. Os lotes são amplos, as edificações em geral isoladas umas das outras, e a cidade é extremamente horizontalizada (BARROS, 1995, p. 151). 


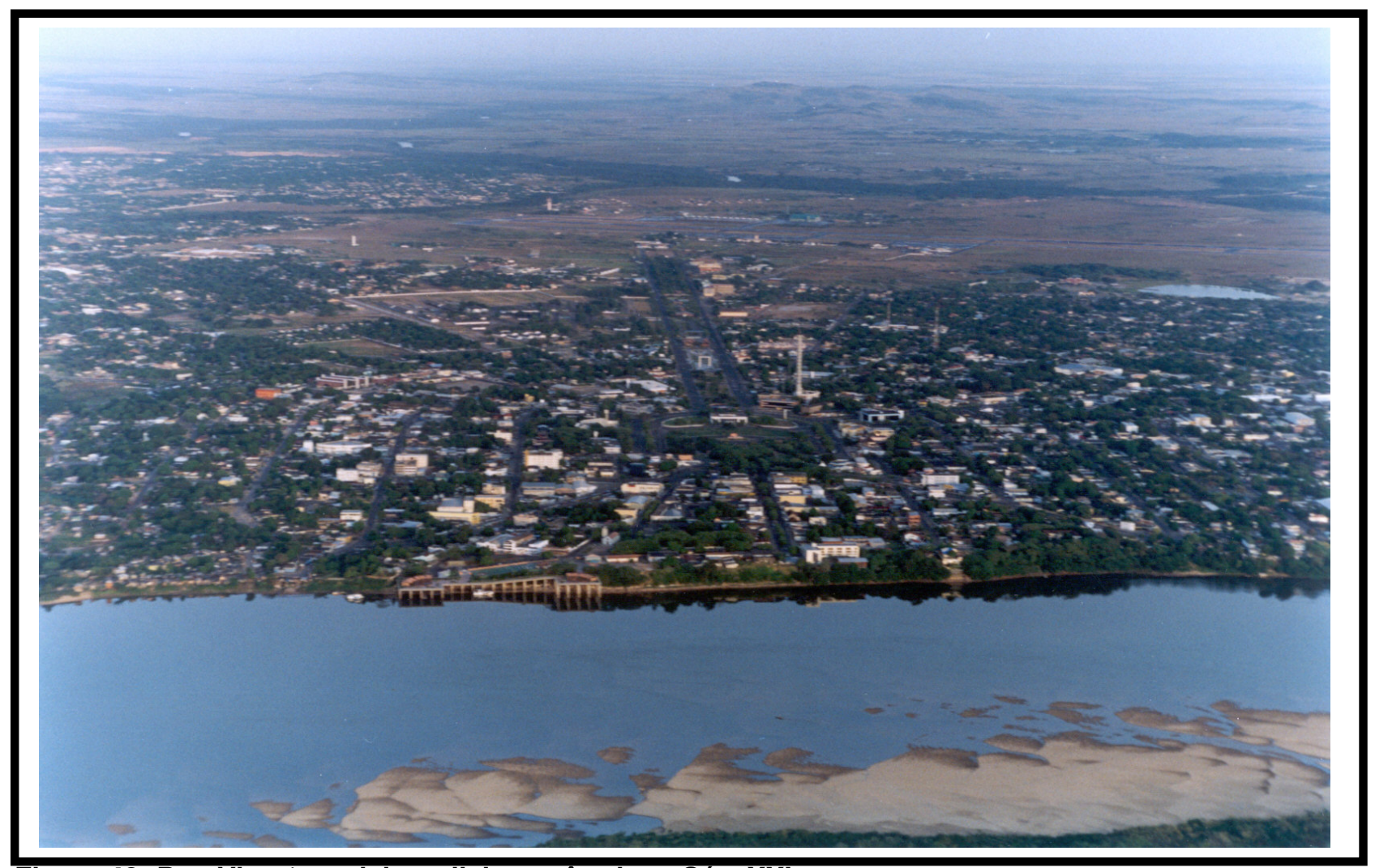

Figura 43: Boa Vista \modelo radial concêntrico - Séc. XXI

Foto: Acervo de Tiago Orihuela

As radiais aguçam a curiosidade dos que as vêem pela primeira vez (Figura 43). Elas ligam os vários extremos da cidade e são cortadas por perimetrais. O epicentro do desenho foi a Praça do Centro Cívico, com a construção do antigo Palácio 31 de março. Ali estar o centro geométrico de Boa Vista (JORNAL A GAZETA DE RORAIMA, 1991).

$\mathrm{Na}$ concepção do engenheiro civil Darcy Aleixo Derenusson, o significado das radiais iam além do significado técnico de construção. Existia um sentimento patriótico que abrangia toda uma região fronteiriça da Amazônia setentrional e representava a presença marcante do Governo Central frente à cobiça internacional. 
Assim, descreve:

Partindo de um centro gerador, busca os confins do norte de nosso território, irradiando a energia de seu povo, como a protegê-lo, Roraima, guardião do Norte.

Lembrem-se. Na época em que foi projetada a planta da cidade de Boa Vista (1944-46) estávamos no fim de uma guerra. E já muito antes disso, não poucos olhos gulosos invadiam nossas fronteiras com missões exploradoras e uma variedade de expedientes para se firmarem e ocuparem nossa terra.

Mais do que simples radiais, mais do que um simples leque, seria a própria alma brasileira, presente, com o corpo e o coração, para garantir a integridade de nossos limites. E, portanto, o sistema radial o símbolo de união territorial, social, lingüístico e ideário do povo brasileiro do Extremo Norte (JORNAL A GAZETA DE RORAIMA, 1991).

Desta maneira, a eficácia da ação urbanística implantada por Êne Garcez confrontava-se com a necessidade de mudança na organização sócioespacial da capital Boa Vista no contexto regional. Essa contemporaneidade urbanística trouxe para Boa Vista um aspecto de cidade bem planejada em relação às outras capitais da região amazônica. Todavia, com a instalação de empreendimentos ou atividades de impactos sem a previsão de infra-estrutura correspondente, a configuração espacial da cidade foi alterada, e sua mancha urbana passou a ter um novo arranjo espacial com a presença de subespaços carentes de equipamentos e serviços.

A urbanização de Boa Vista fazia parte de uma política de fomentar a capital Boa Vista de equipamentos urbanos com o objetivo de amenizar a carência da população do território e fortalecer a presença do Governo Central na fronteira Norte do país.

Para o Prof. Milton Santos (2002),

Essa ação política pode, em muitos casos, ser orientada, apenas, para um interesse particular e específico, freqüentemente o da atividade hegemônica no lugar. Mas este é, apenas, um primeiro momento. As atividades que, complementares ou não, têm uma lógica diversa da atividade dominante, provocam, a partir de seu conflito de preocupações, um debate que acaba por interessar ao conjunto da sociedade local. E o resultado é a busca de um sistema de reivindicações mais abrangentes, adaptado às contigências da existência comum, no espaço horizontalizado.

Esta ação pode ser expressa na ascensão política de alguns ex-governadores que passaram pelo ex-território e que permaneceram na região em virtude de interesses pessoais e político-partidários; também, por meio dos fazendeiros, dos religiosos e comerciantes influentes que direcionavam as ações em prol das classes 
dominantes. Como exemplo, há as propriedades fundiárias urbanas, que na sua maioria são de domínio desses respectivos agentes promotores do espaço urbano.

Desta maneira, o caminho para o desenvolvimento urbano sustentável de Boa Vista é justamente tentar completar as partes ausentes nos ideais de Darcy Aleixo Derenusson, que acreditava na possibilidade de planejamento de comunidades balanceadas com mistura de classes sociais, desenvolvimento econômico e bem-estar social atrelado ao desenho da paisagem sem a influência desses agentes.

Cabe esclarecer, ainda, que a comparação que se faz da cidade Boa Vista (Figura 44) com a cidade de Paris (Figura 45), deve-se à função de seu desenho urbano - também radial concêntrico, com avenidas largas e belos jardins com espaços abertos e verdes para melhorar a salubridade da cidade e o lazer de sua população, sempre convergindo para a praça principal. 


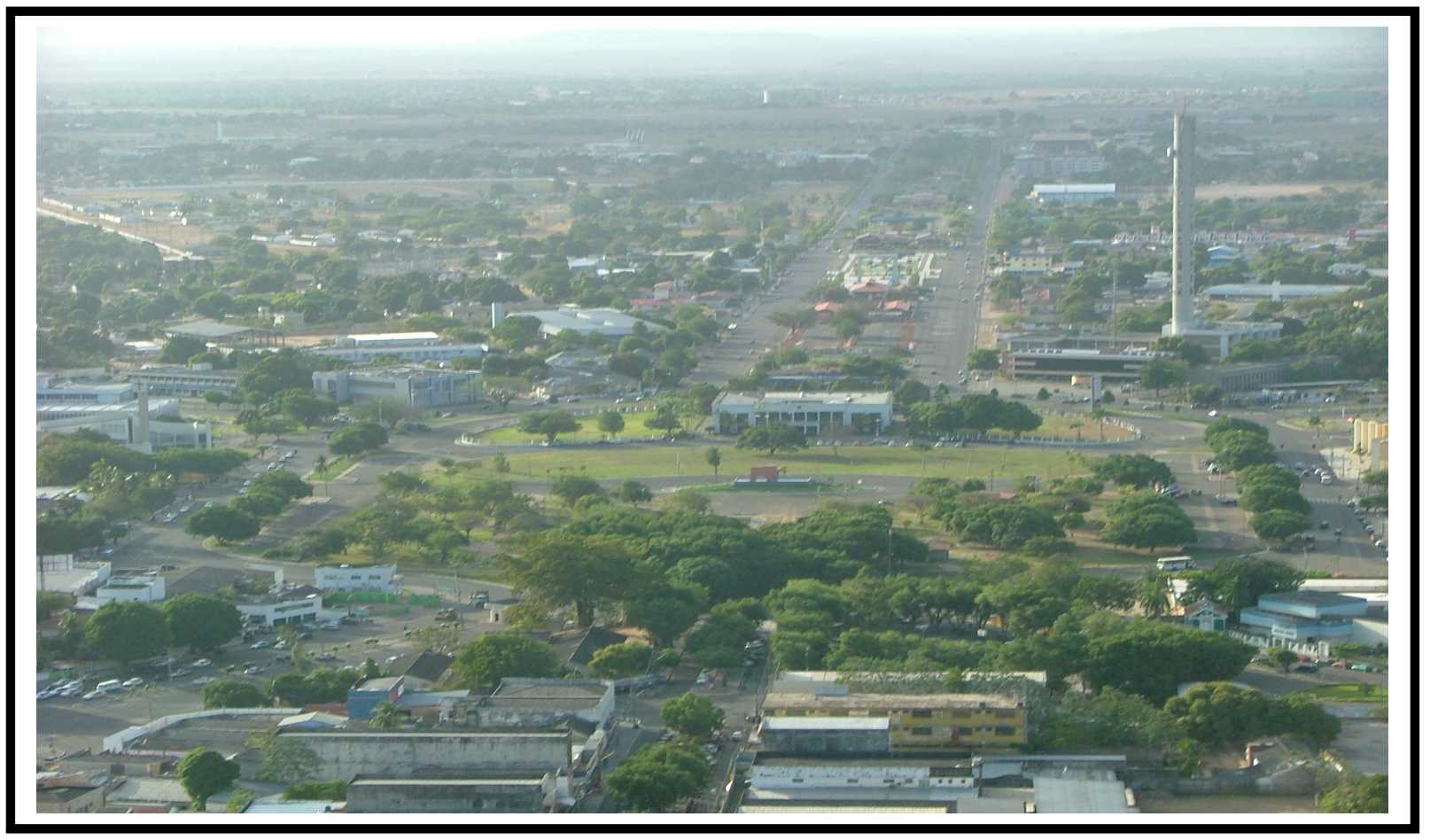

Figura 44: Vista Aérea da Praça do Centro Cívico de Boa Vista $\backslash 2008$ (o controle da Cidade Administrativa, através do eixo central)

Foto: Acervo de Roberto Callefi - UFRR

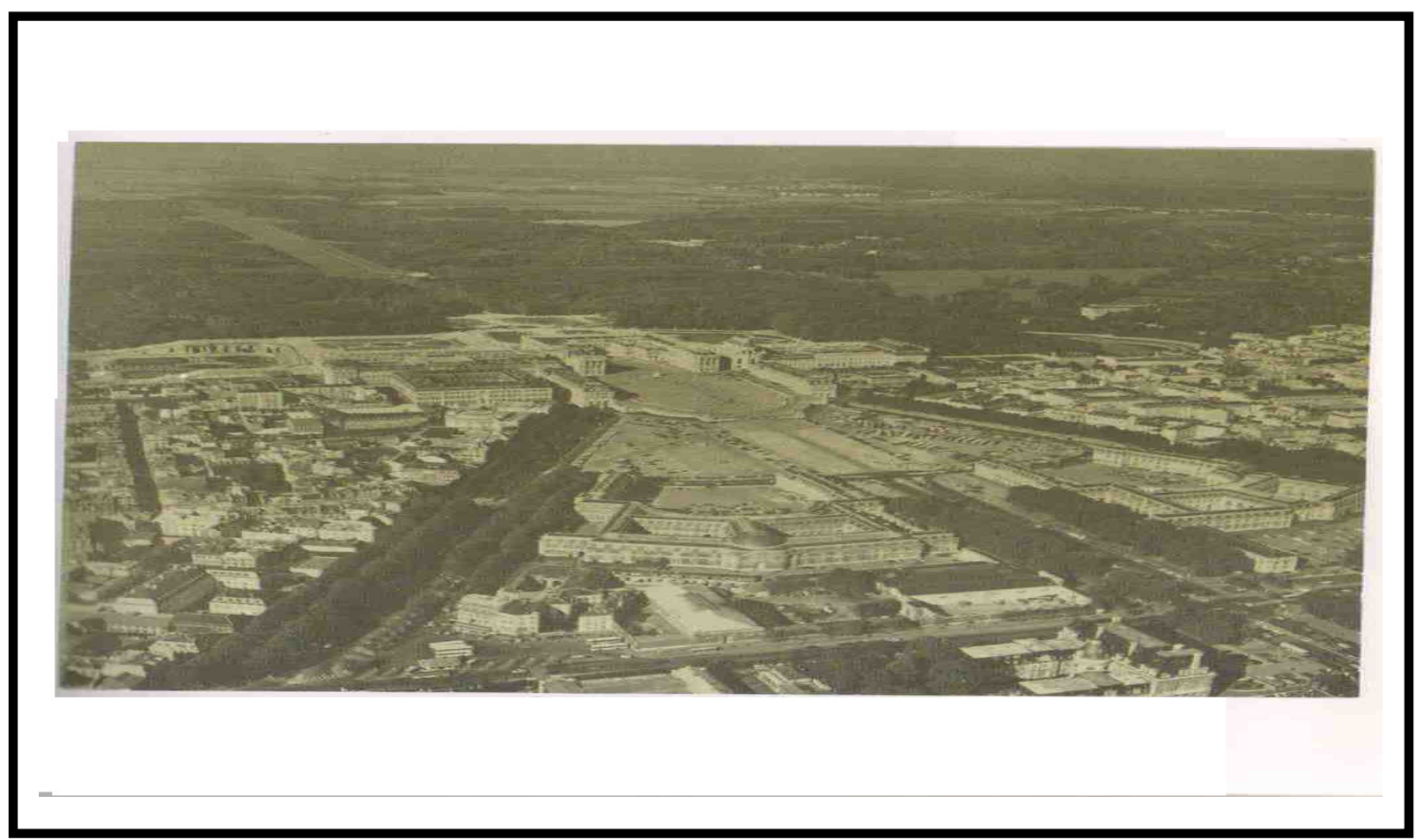

Figura 45: Vista Aérea $\backslash$ Versalhes-Paris

(o controle da natureza e da Cidade Administrativa, através do eixo central básico, com lago e avenidas arborizadas)

Foto: Acervo de Howard, 1996 
No que concerne às formas de interação urbana, o modelo radial concêntrico é considerado como um conjunto de elementos humanos exercendo atividades diferenciadas num espaço também diferenciado e onde se podem distingui as seis formas de interação urbanas: a) Concentração: que se refere a adensamento da população ou atividades em áreas centrais do espaço urbano; b) Dispersão: o processo inverso à concentração; c) Segregação: processo dissociativo que leva grupos de indivíduos a isolarem-se, física e socialmente, de outros grupos ou indivíduos, em virtude de diferenças econômicas, profissionais, de locais de residência, entre outros; d) Invasão: inserção em uma área de um novo tipo de morador; e) Sucessão: substituição, em uma mesma área, de um tipo de morador por outro tipo de morador; e f) Dominância: controle econômico de uma comunidade maior sobre uma comunidade satélites ou dependentes (FERRARI, 1982, p. 312-314). 


\section{CAPÍTULO III: A CIDADE DE BOA VISTA}

Neste capítulo, pretende-se expor, de forma científica, as ações políticoadministrativas de desenvolvimento na Amazônia e sua relação com Boa Vista, a dinâmica de produção do espaço urbano de Boa Vista após a implantação do Plano Urbanístico da cidade e a criação do Estado de Roraima com a Promulgação da Constituição Brasileira de 1988. Nesses três períodos, percebe-se estampada na paisagem a estrutura de classes, isto é, o caráter de classes da organização do espaço. Verifica-se com clareza uma formação de múltiplos espaços desiguais com a atuação descontinua dos ex-governadores do território e respectivos prefeitos de Boa Vista. Os objetos do arranjo espacial são mais visíveis na paisagem, isto é, os fixos e fluxos articulam-se como processo de (re) produção, como instrumentos de trabalho e meios de consumo individual e coletivo na cidade. As três esferas de governo: Federal, Estadual e Municipal - assumem um papel relevante no processo de produção sócioespacial da cidade por meio de ações político-administrativas com o objetivo de dotar a cidade de equipamentos e serviços que venham a amenizar as necessidades da população local.

\subsection{Localização do município de Boa Vista: destaque para a área de estudo: mancha urbana}

O município de Boa Vista, capital do Estado de Roraima, está situado no

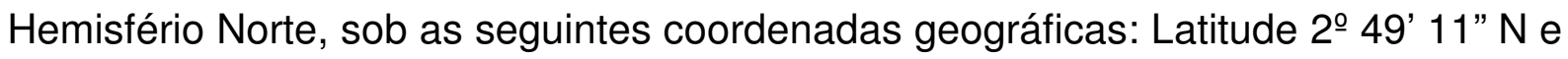
Longitude 60 40' 24" Oeste de Greenwich. O município ocupa uma área de 5.687 $\mathrm{Km}^{2}$ e possui aproximadamente 236.319 habitantes. Possuindo seus Limites ao Norte com os municípios de Normandia, Pacaraima e Amajarí; ao Sul com Mucajaí e Alto Alegre; a Leste com Bonfim, Cantá e Normandia e a Oeste com o município de Alto Alegre (IBGE, 2004) (Mapa 8). 


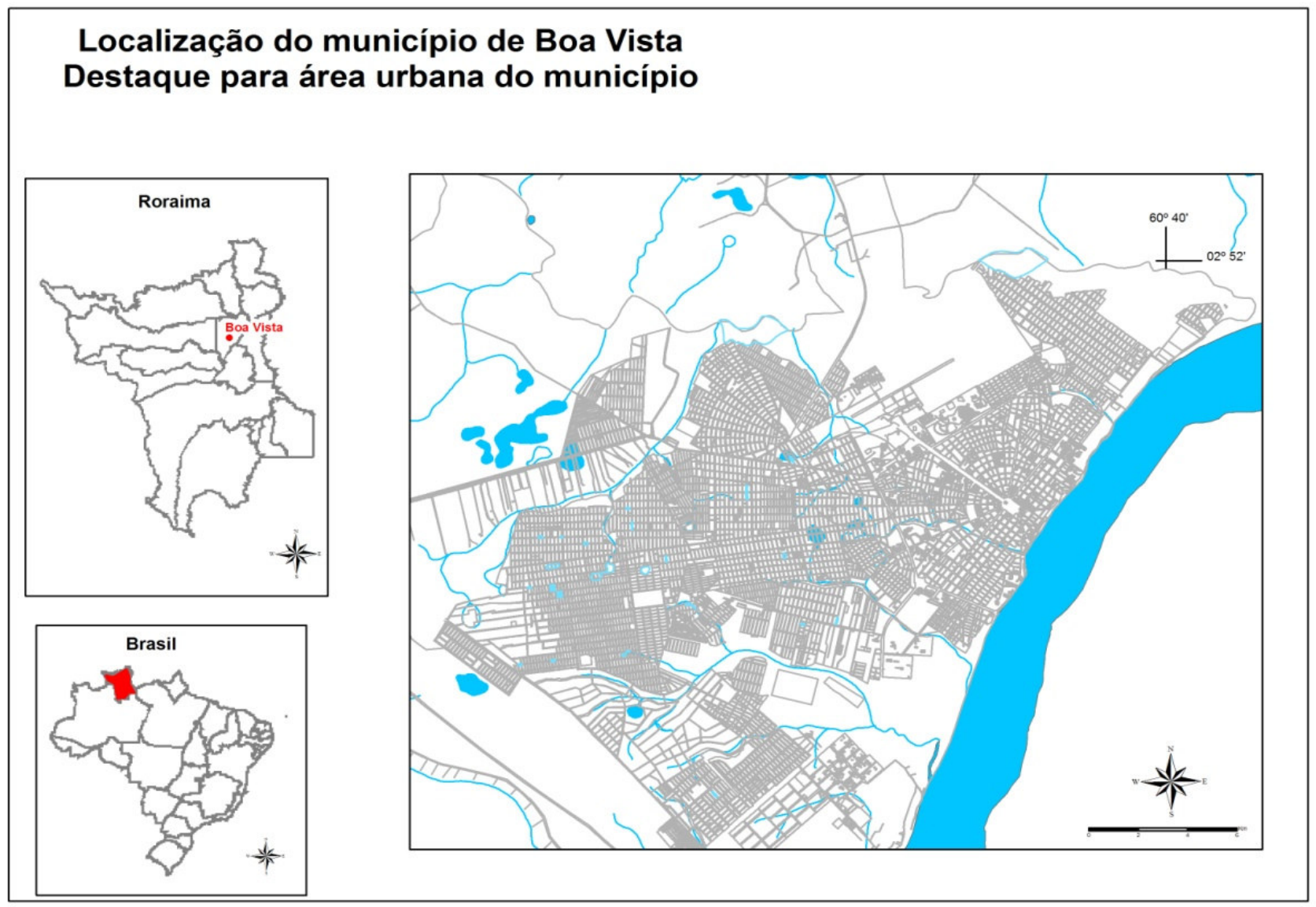

Mapa 8: Localização do Município de Boa Vista : Destaque para a área de estudo: Mancha urbana Organização: Antonio Tolrino de Rezende Veras e Letícia Palazzi

Fonte: IBGE, 2004. 


\subsection{Território Federal do Rio Branco (Roraima) face as ações político- administrativas de desenvolvimento na Amazônia e sua relação com Boa Vista}

A partir da segunda metade da década de 1950, a Amazônia experimentou um surto de crescimento que resultou em uma expansão bastante significativa da economia regional. É quando se inicia a incorporação da Região ao mercado nacional polarizado por São Paulo, com o término da construção das rodovias Belém-Brasília e Cuiabá-Porto Velho no início da década de 1960 (SILVA, 2006, p. 1-9). Com essa realização, iniciou-se a mais forte investida da expansão interna na região Amazônica, liderada por grandes grupos internacionais.

Durante os governos militares (1964-1985), a estratégia de ocupação da Amazônia favoreceu a criação de mecanismos de incentivo à penetração do capital nacional e internacional no mercado de terras, assegurando vantagens fiscais para a criação de grandes projetos agropecuários. Isso atraiu trabalhadores rurais para programas de colonização dirigida, abrindo estradas e consolidando a infra-estrutura de transportes, comunicações e energia elétrica, prioritariamente para insumo energético de grandes indústrias do setor mineral (SILVA, 2006, p. 1-9).

O período de 15 anos, que separa o golpe de 1964 do inicio da década de 80, reforça a consolidação da presença do Estado na região Norte frente à dimensão da região e sua posição estratégica e geopolítica. [...] o Estado vai lançar mão de planos nacionais e regionais de desenvolvimento, dos quais o pioneiro foi o Plano de Ação Econômica Governamental - PAEG, ao qual se seguiram o Plano de desenvolvimento - PND I e II, este último tendo um desdobramento na forma do II PND - Amazônia. [...]. A primeira grande medida é a transformação da SPVEA (Superintendência do Plano de Valorização Econômica da Amazônia) em SUDAM Superintendência do Desenvolvimento da Amazônia - e a criação de uma entidade espacial e legal - a Amazônia Legal. Entre os objetivos da SUDAM, destaca-se: o de promover o desenvolvimento da região a partir da isenção de impostos fiscais as empresas que investissem na região. (BAHIANA, 1991, p. 15-23). 
Reforçando as considerações de Bahiana (1991), Santos (2004, p. 1) expõe:

[...] foi somente após 1964 que o poder público, através da imposição de um projeto de modernização, inseriu a Amazônia nas bases produtivas nacionais. Ao longo desse processo, segundo Becker (1998), a Amazônia assumiu importante posição-chave perante as prioridades econômicas e geopolíticas, além de ser considerada uma solução para os problemas de tensão social do Nordeste e da continuidade do crescimento econômicosocial do Sudeste. Essa profunda e abrangente intervenção atingiu o cotidiano das populações amazônicas, transformando o espaço geográfico, modificando o universo das relações econômicas, sociais e políticas. $O$ incentivo a atividades produtivas, o aumento populacional, a abertura de rodovias e implantação de novas estruturas técnicas e administrativas, fazem parte desse conjunto.

Desta forma, o ponto de partida para compreender as transformações profundas no espaço regional amazônico, na década de 70 e início da década de 80, parte em busca por essas transformações no projeto geopolítico do governo, de garantir o poder do Estado sobre as fronteiras nacionais. Tais fronteiras é o alicerce da estratégia de ocupação do território - que é acoplado ao projeto econômico, indutor dos investimentos estatais e internacionais, explicitado nos Planos Nacionais de Desenvolvimento, I e II.

Na década de 70, deu-se o lançamento do Programa de Integração Nacional (PIN), mediante o Decreto Lei no. 1.106, de 16106170, que, sob uma visão integracionista da nação, objetivava melhorar as condições para a expansão do capital e para minimizar a crise de desemprego no Nordeste e no Centro-Sul, assentando em projetos de colonização migrantes dessas duas regiões (OLIVEIRA 1988, p. 65-115).

Considerando as observações de Oliveira (1988) a respeito da Amazônia, compreende-se que a integração física e a ocupação passaram a ter uma importância vital, visto que a intenção era unir as áreas menos e as mais desenvolvidas do Norte e do Sul, além de atrair para essas regiões a mão-de-obra não qualificada do Nordeste, que, então, utilizaria e ocuparia as terras e outros recursos da Amazônia.

Em 1971, foi lançado o Programa de Redistribuição de terras (PROTERRA), que complementava o PIN. Ambos tinham como objetivo promover a integração, a ocupação humana e o desenvolvimento econômico por meio do setor agrícola e rural. 
Como os projetos de colonização começaram a falhar, em 1973 as grandes empresas passaram a assumir a tarefa de "desenvolver" a área amazônica. Com isso aumentou a penetração da pecuária e dos grandes latifúndios, cuja posse se fez tanto de forma legitima quanto ilegítima. A finalidade era para fins de criação, de reserva de valor e de especulação. Com esse avanço, a situação dos grupos indígenas e da pequena propriedade familiar foi ficando cada vez mais precária e os conflitos pela posse da terra se acentuaram (OLIVEIRA, 1988).

Em relação ao Território Federal de Roraima, a inserção dessa política foi efetiva com a criação do POLORORAIMA em 1975, como parte do programa de Pólos da Amazônia (POLAMAZÔNIA). Esta ação inseria no espaço regional do território investimentos financeiros com o objetivo de incentivar a vinda de mão-deobra, que era escassa, por meio da migração, bem como proporcionar a implantação de colônias e estradas, entre outros (BARBOSA, 1993, p. 179).

Cabe dizer que o programa POLAMAZÔNIA fazia parte do II Plano de Desenvolvimento da Amazônia (PDA) e constituía-se num elemento complementar e, ao mesmo tempo, concorrente do Fundo de Investimento da Amazônia (FINAM). Ambos captavam recursos do imposto de renda de pessoas jurídicas. Porém, com gerenciamento e destinos diferentes, isto é, no caso do programa de pólos, o Estado gerenciava os recursos destinados ao PIN e ao PROTERRA [...] os investimentos eram realizados somente pelo setor público e seguiam os objetivos governamentais de desenvolvimento para a região. O FINAM, destinava-se exclusivamente para o setor privado, sendo gerenciado pelo Banco da Amazônia (BASA) e supervisionado pela SUDAM (BARBOSA, 1993).

Conforme Barbosa (1993, p. 180)

Os investimentos previstos pelos programas, supracitados contemplavam a implantação de novas colônias agrícolas, abertura de novas estradas, regularização da posse da terra entre outros [...] tais investimentos, possibilitou a entrada de massas populacionais para Roraima. No entanto, o fluxo de pessoas não foi maior devido o difícil acesso a região, e em parte, por conta da governança do território que era regido por militares - pouco estimulados ao desenvolvimento de uma base política futura. Esse fato só veio a mudar somente no inicio da década de 80 , quando se cogitou a transformação do Território Federal de Roraima em um Estado da federação.

Com a conclusão da $\mathrm{Br} 174$ e de parte da $\mathrm{Br} 210$ na década de 70, o programa governamental manteve firme a base de estruturação para uma expansão mais abrangente no território, em particular na cidade de Boa Vista, que funcionava como entreposto da região do Alto Rio Branco. Convém destacar que uma parte da verba destinada para a construção deste sistema de engenharia era oriunda do 
Ministério do Exército. Para Barbosa (1993) essa particularidade permitia o cunho de segurança nacional, ou seja, existia uma preocupação geopolítica nos projetos dos governos militares na Amazônia.

Na análise de Barbosa (1993, p.180), o Programa de Ação do Governo de Roraima no interstício de 1975 a 1979, estava pautado no plano estratégico do governo federal para a consolidação e ocupação físico-territorial desta região [...]. Essas ações visavam à ocupação ou reestruturação de núcleos habitacionais para a prestação de serviços e apoio à população de colonos [...], sendo o Instituto de Colonização e Reforma Agrária - INCRA, responsável pelas questões agrárias. No final da década de 70 e inicio da década de 80, Roraima deu inicio ao processo de assentamento humano dirigido. Os projetos de maior expressão foram montados nas regiões centro-Oeste e Leste do território - Colônia de Alto Alegre e os Programas de Assentamentos Rápidos (PAR) Apiaú e Barauana, estes por estarem localizados próximos à capital Boa Vista [...]. A partir destes núcleos, várias vilas foram se formando - São João da Baliza, São Luís do Anauá entre outras -, todas embriões das chamadas "cidades pioneiras".

Com a implantação das colônias, deu-se o aparecimento dos aglomerados urbanos e, conseqüentemente, a criação de novos municípios, que permitiu aos políticos locais justificar a entrada de recursos federais através do Fundo de Participação Municipal - FPM. Essa iniciativa na acepção de Barbosa (1993, p. 185), era uma estratégica para a futura criação do Estado de Roraima.

Neste contexto, as áreas territoriais da cidade de Boa Vista e Caracaraí foram desmembradas, dando origem a seis sedes municipal: Alto Alegre, Bonfim, Mucajaí, Normandia, São João da Baliza e São Luis do Anauá, por meio da Lei oㅜ 7.009, de 01 de julho de 1982 (BARBOSA, 1993).

O incentivo por parte do governo aos assentados não foi uma constante (situação ainda presenciada hoje - grifo nosso). Faltava transporte para escoar a produção, crédito financeiro, auxílio técnico entre outros. Conseqüentemente os colonos deslocavam-se para a cidade de Boa Vista em busca de melhores condições de vida. Essa migração dava-se em função da cidade ser o único centro urbano com condições aparentes de fornecer equipamentos e serviços à população no vale do rio Branco. Ao chegar à cidade, não tinham apoio logístico por parte do gestor público. Situação que resultou num processo de aglomeração populacional na 
periferia da cidade, e, ao mesmo, num desordenamento territorial urbano e numa demanda por equipamentos urbanos.

O III Plano Nacional de Desenvolvimento, implantado no interstício de 1980 185 , mencionava a necessidade de se "promover a exploração racional e não predatória de novas áreas, como, por exemplo, da Amazônia”. No entanto, segundo Oliveira (1988), tais políticas desenvolvimentistas, ao invés de fomentarem o desenvolvimento mediante a implantação das atividades programadas, deram origem a uma grande mobilidade de migrantes para a região, acompanhada da introdução de novas tecnologias, o que acabou por colocar em risco o equilíbrio da natureza, como ocorreu no caso do desmatamento.

Para Oliveira (1988, p. 100-115),

Com a instalação de mineradoras, de hidroelétricas, de projetos agropecuários, de madeireiras, a construção de grandes estradas e o incentivo à colonização, a mais exótica e mais complexa região de floresta tropical úmida está sendo afetada por atividades predatórias do homem e a finalidade almejada, que é o povoamento e o desenvolvimento da área, não está sendo conseguida da forma planejada, uma vez que muito poucos empregos permanentes foram criados, não se resolveu o problema da crise agrária do Nordeste e do Centro - Sul.

Segundo Oliveira (1988), o que tem acontecido, na verdade, é que a violência e a miséria crescem cada vez mais com o surgimento de conflitos pela posse de terra. Além disso, em muitos casos, as condições de infra-estrutura econômica e social sobre os serviços públicos são absolutamente precárias.

Esse foi um do fato que levou o Governo Federal, em 1985, a implantar o projeto Calha Norte (Mapa 9). De caráter estritamente estratégico e geopolítico, tal projeto foi instituído para proteger uma extensa faixa de fronteira na Amazônia, profundamente despovoada e carente de infra-estrutura, que mereceu e merece do Governo Federal cuidados especiais. Assim, a idéia de desenvolvimento econômico nas faixas de fronteira, especialmente em Boa Vista, firmava-se na ocupação gradual e sistemática dessas áreas, mediante políticas do Governo calcadas em projetos de colonização dos vazios existentes na região. 


\section{ÁREA DE IMPLANTAÇÃO DO PROJETO CALHA NORTE}

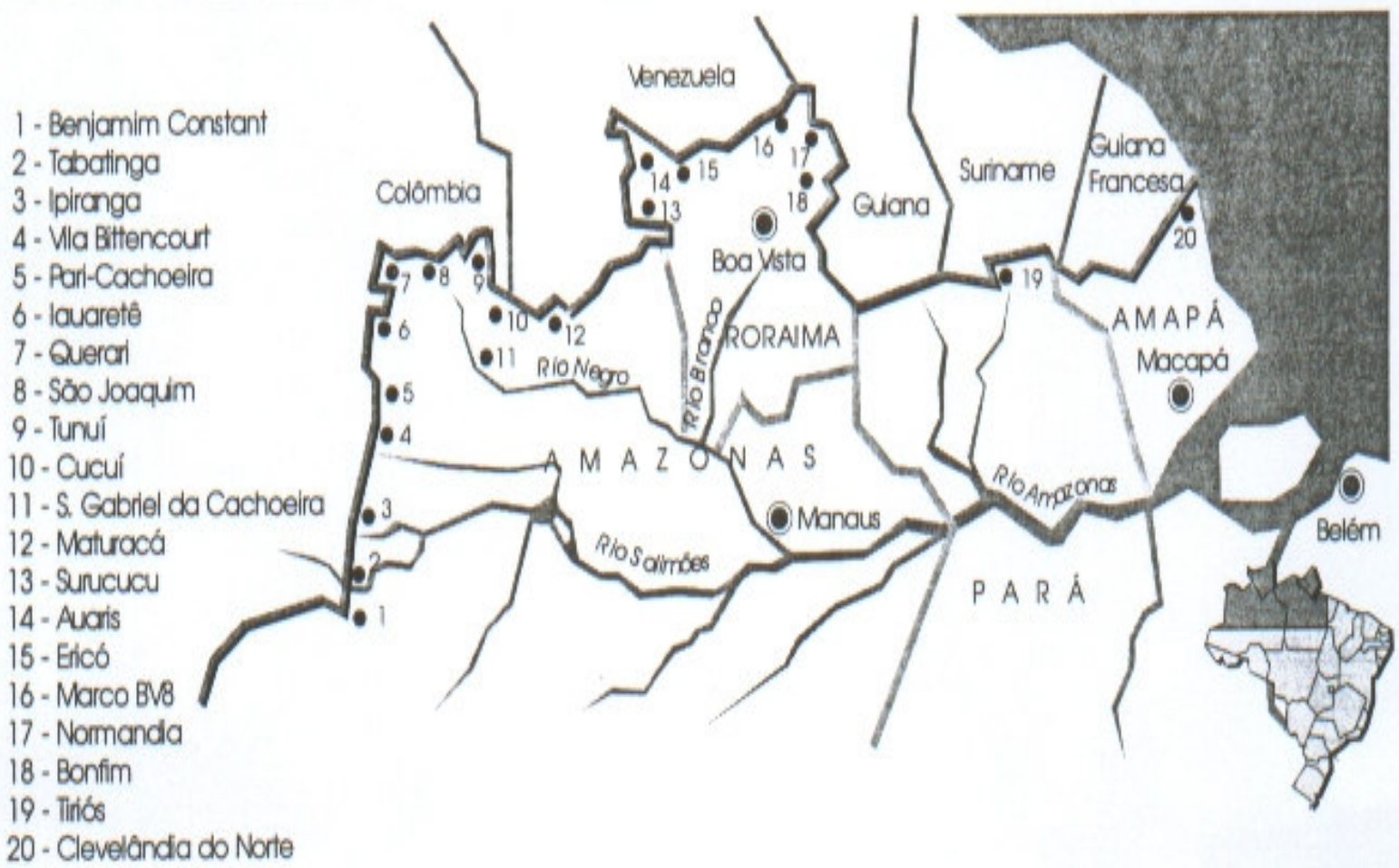

Mapa 09: Posição estratégica e geopolítica de Boa Vista no projeto Calha Norte Fonte: On line - site: www.comciencia.br

No I Plano de Desenvolvimento da Amazônia da Nova República (1986\1989) - o que tinha como propósito, basicamente, "interiorizar e internalizar o desenvolvimento" -, voltava-se para a retórica do "desenvolvimento nacional". Possuía, na concepção de Oliveira (1988), um caráter globalizador, pretendendo harmonizar aspectos diversos, como "desenvolvimentismo"; controle geopolítico; defesa ecológica; desenvolvimento comunitário; controle estatal sobre a expansão e a preponderância de organismos regionais e proteção de comunidades indígenas mediante a demarcação de suas terras entre outros. 


\subsubsection{A cidade de Boa Vista - dinâmica de produção}

Considerando o exposto, supracitado, percebe-se que o processo de produção do espaço urbano de Boa Vista é decorrente de um conjunto de relações executadas por meio de formas e de funções que se articulam como testemunho de uma história escrita por processos do passado e do presente. Tal compreensão se baseia em Santos (1990, p. 122) ao afirmar que o espaço se traduz por meio de um conjunto de formas representativas de relações sociais,econômicas e políticas que estão acontecendo diante dos nossos olhos e que se apresentam por meio de processos e funções. Em que o espaço passa a ser um verdadeiro campo de forças cuja aceleração é desigual.

Neste caso, o espaço urbano de Boa Vista é um testemunho. Ele testemunha diversos períodos de um modo de produção pela memória do espaço construído, das coisas fixadas na paisagem criada ao longo de sua formação sócioespacial, resultante das instâncias estruturais por ele constituídas. Essa produção sobrevive pelas formas espaciais, pelos modos de produção ou de seus momentos de formação (SANTOS, 1990, p. 145).

Como assevera Santos (1990, p. 162), produzir e produzir espaço são duas coisas inseparáveis. Pela dinâmica de produção o homem altera a natureza primeira ou natureza bruta, socializando-a [...]. É por isso que o espaço é criado como natureza segunda, natureza transformada, natureza social ou socializada. Portanto $o$ ato de produzir é, ao mesmo tempo, o ato de produzir espaço.

Em Boa Vista, a dinâmica de produção realizada pelo homem ao longo de sua formação sócioespacial contribuiu para que ele escrevesse constantemente sua história, que é ao mesmo tempo a história do trabalho produtivo e a história do espaço. Assim, as novas atividades exigiam um lugar no espaço e determinavam uma nova arrumação para as coisas, uma disposição diferente para os objetos geográficos, uma organização do espaço (SANTOS, 1990, p. 164).

A produção do espaço consiste, então, na realização prática de produção de objetos "geograficizados" segundo uma dada lógica econômica, e destinam-se a cumprir funções diferenciadas em sintonia com as necessidades de reprodução das relações sociais de produção e da divisão social do trabalho (GODOY, 2004, p. 29-42). 
Assim, a produção do espaço urbano de Boa Vista é, pois, um produto resultante de ações sociais, econômicas e político-institucionais acumuladas através do tempo no espaço físico. A ação destes agentes, na compreensão de Corrêa (1989, p. 29), é complexa, derivada da dinâmica de acumulação de capital, das necessidades mutáveis de reprodução das relações de produção e dos conflitos de classe que dela emergem. Estas ações provocam um constante processo de reorganização espacial que se realiza através da incorporação de novas áreas ao espaço urbano, densificação do uso do solo, deterioração de certas áreas, renovação urbana, relocação diferenciada da infra-estrutura e mudança do conteúdo social e econômico de determinadas áreas da cidade (MARINATO, 2000, p. 6-15)

\subsection{Dinâmica intra-urbana de Boa Vista a partir da implantação do plano urbanístico}

Com a criação do Território Federal do Rio Branco e, posteriormente, a implantação do plano urbanístico, as ações políticas eram diversificadas. $\mathrm{Na}$ verdade, existia uma mesa de jogo - a cidade -, em que os jogadores, em particular, os governadores indicados pelo o Governo Federal e seus prefeitos indicados pelos respectivos governadores, articulavam planos "estratégicos", em sua maioria, com base no Plano Qüinqüenal (1945-1949) elaborado pelo Capitão Êne Garcez. O objetivo era definir políticas de desenvolvimento urbano "sustentável" para a cidade. Nessa trama, os agentes promotores do espaço urbano - fazendeiros, religiosos, comerciantes influentes entre outros -, comandavam a dinâmica sócioespacial da cidade em conformidade com seus interesses.

Em Boa Vista, o agrupamento destes elementos respeitavam normas, fazendo que o processo de produção e (re) produção do espaço urbano parecesse um jogo de carta onde os participantes possuíam interesses particulares ou comuns. 
Carlos Nelson dos Santos (1988, p. 50) é autor do livro "A cidade como um jogo de cartas" onde exemplifica esta situação aplicada a um jogo de cartas:

\begin{abstract}
$\mathrm{O}$ que acontece com uma cidade pode ser comparado ao jogo de cartas. $\mathrm{O}$ jogo urbano se joga sobre um sítio determinado que é a sua "mesa". Aí se juntam parceiros que se enfrentam segundo os grupos e filiações a que pertençam. Há os políticos, técnicos e funcionários que representam o governo. Aqui, é preciso distinguir de que nível de governo se trata, pois sobre as cidades intervêm agentes federais, estaduais e municipais. Existem as empresas que agem através de investimentos na indústria, no comércio, e nos serviços, com especial destaque para o capital ligado aos ramos imobiliário e da construção civil, cujas ações têm reflexos diretos no meio urbano. Por fim entra a população, fragmentada nos mais diversos grupos. (vizinhança, filiação política e religiosa, profissão, parentesco, afinidades...).
\end{abstract}

A cidade, neste contexto, expressa alianças entre grupos e formas de regulação territorial, isto é, os indivíduos presentes e ausentes no território estabeleciam o máximo de controle sobre a dinâmica sócioespacial da cidade.

Desta maneira, a dinâmica de produção da cidade ficava condicionada aos interesses dos grupos dominantes, em particular, dos ex-governadores que na sua maioria, não permaneciam por muito tempo no cargo. Na verdade, existia uma descontinuidade política de um governador em relação a outro, bem como dos prefeitos indicados.

Outro agravante era que a maioria dos governadores indicados não conhecia a realidade do território. Essa situação, na concepção de Freitas (1993, p. 91), foi responsável pelo desrespeito às tradições e aos valores locais, os quais eram violentados, uma vez que os respectivos governadores, ao realizarem suas ações, não faziam uma consulta prévia à população para saber as reais necessidades locais.

Convém observar, também, que os interesses políticos locais, os projetos e programas propostos pelo Governo Central não associavam expansão urbana a ordenamento territorial urbano. Com isso, a cidade, apesar de ser planejada, já apresentava um crescimento desordenado.

Com a saída de Êne Garcez em 1946, o projeto urbanístico da cidade ficou a mercê da administração dos seus sucessores. Fato que contribuiu diretamente para a não conclusão do projeto no prazo previsto que era o ano de 1950.

Entre os seus sucessores que contribuíram para o desenvolvimento urbano de Boa Vista, podemos mencionar: 
1. O Governador Féliz Valois de Araújo, que, ao construir o primeiro conjunto habitacional, na cidade, alterou a paisagem urbana. No caso, o espaço urbano - desigual, dinâmico e mutável -, adquiriu novos ritmos espaciais.

2. O Capitão Clóvis Nova da Costa, que governou de $1948 \backslash 49$ e $1962 \backslash 63$. Seu governo foi considerado crítico em relação à atuação do Governo Central no Território. Achava que o Território Federal do Rio Branco apresentava diversas reservas naturais, por outro lado, os recursos financeiros e técnicos destinados para o seu desenvolvimento eram exíguos frente aos diversos problemas existentes na região. Ambos já mencionados no subitem 2.2.2.

$\mathrm{Na}$ compreensão de Costa (1949, p. 161-162), era imprescindível que o Governo Federal ampliasse os investimentos para a região, bem como a assistência técnica profissional em todas as atividades produtivas [...]. Os investimentos financeiros deveriam ser destinados para os setores de transporte, comunicação, colonização e aproveitamento dos recursos naturais existentes na região [...], além disso, o desenvolvimento do Território do Rio Branco necessitava de um financiamento de amplas proporções mediante recursos orçamentários, empréstimos com facilidades de amortização, juros e prazos, e percentagens das receitas especiais da valorização da Amazônia.

Ainda, segundo Costa (1949), o agente econômico era imprescindível e determinante no processo de produção da cidade e do território.

Um fato interessante que merece destaque nas atuações dos exgovernadores e que diz respeito ao plano urbanístico, foi à ação do ex-governador Aquilino Duarte em 1952, o qual queria mudar o plano urbanístico da cidade. No entanto não logrou êxito pela reação popular manifestada, que não apoiava a proposta do governador (FREITAS, 1993).

Conforme Freitas (1993, p. 93),

[...] O governo Aquilino Duarte queria deixar uma cidade antiga intocável. E se dizia que esta teria sido uma medida sensata se tivesse sido tomada, inicialmente, fazendo-se apenas pequenas correções, pois o traçado antigo era bastante regular, honrando a mentalidade dos antigos prefeitos do tempo em que éramos município do Estado do Amazonas. Todavia, segundo reportagem do jornal "O Átomo" no 93 de 1953, com o Plano Urbanístico traçado e já tendo sido, em grande parte, executado, gastando-se, por conseguinte, uma boa soma de recursos, a opinião pública evitou que o governo Aquilino Duarte alterasse o Plano Urbanístico da Boa Vista. Caso isto tivesse sido executado, seria de se lamentar, uma vez que a cidade de Boa Vista, com seu belo traçado é, hoje, um dos orgulhos dos boavistenses. 
Para Guerra (1957, p. 138) na década de 50, a cidade já apresentava uma tendência de crescimento para o setor Oeste e norOeste, a partir do bairro Centro. Ele afirmava que o estilo das casas era diferenciado de um bairro em relação a outro e o traçado das ruas também apresentava grandes contrastes (Figura 46 e 47).

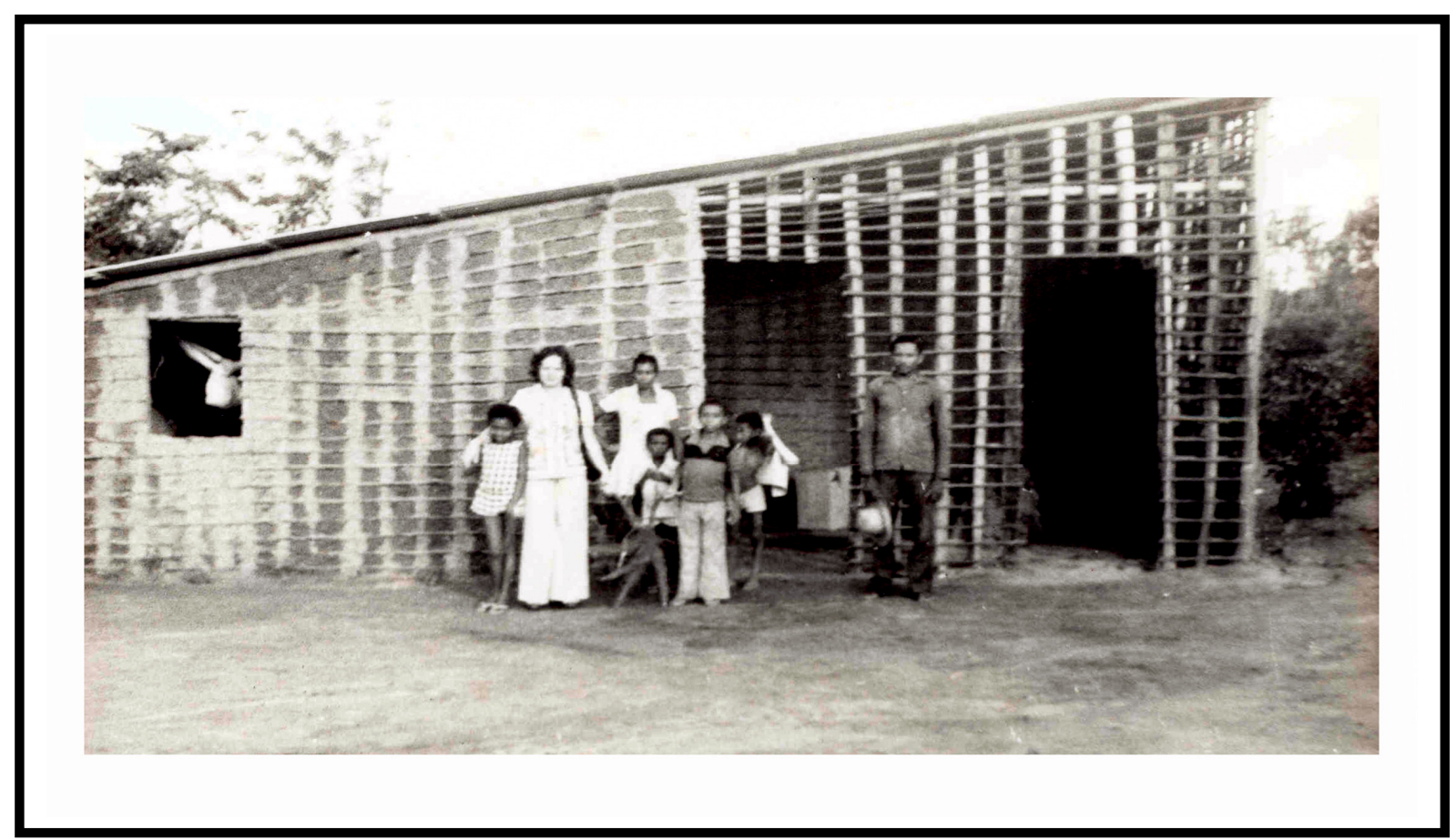

Foto 46: Arquitetura das casas - Década de 50 (Setor Oeste - próximo as margens do rio Branco)

Foto: Acervo de Tiago Orihuela

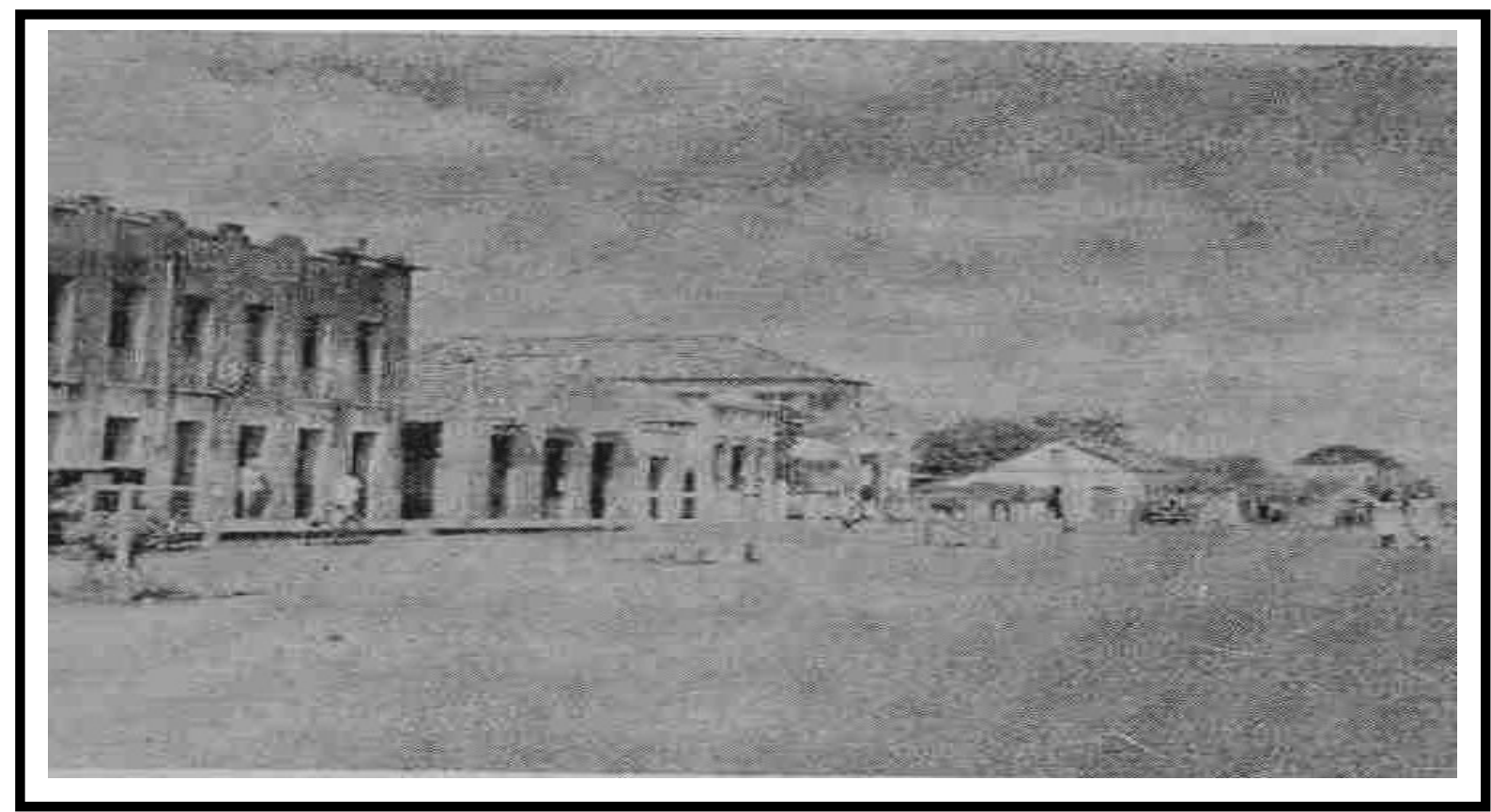

Figura 47 Arquitetura das casas - Década de 50 (Bairro Centro - Av. Jaime Brasil)

Foto: Acervo de Tiago Orihuela 
Esse contraste na configuração espacial apresentava-se num período em que a cidade estava sendo urbanizada. Para o autor, certas construções da época não obedeciam a nenhum plano urbanístico (GUERRA, 1957).

Essa diferenciação na apreciação de Guerra (1957, p. 139-142) é analisada de forma sensata pelo o Doutor Valério Caldas de Magalhães, ao se referir ao processo de urbanização da cidade:

\begin{abstract}
A cidade de Boa Vista, cujo traçado obedece a um plano organizado em 1945, está no momento apresentando um aspecto desolador no que tange ao urbanismo, pois nada menos de três cidades, em rigor, estão se prejudicando mutuamente: a cidade velha do tempo do município do amazonas; a parte nova construída dentro de um plano e outra que vem sendo construída a título de emergência, casas desordenadas, sem alinhamento e sem estética...
\end{abstract}

Conforme Guerra (1957) e a Série Monográfica de Boa Vista (1987) na década de 50 a cidade era dividida em 5 (cinco) bairros:

- Porto da Olaria (hoje, bairro São Francisco e Caetano Filho), localizado entre a atual Praça Barreto Leite e o Calungá. Sua designação é em decorrência de existir uma série de olarias na parte baixa da margem direita do rio Branco. Era considerado o bairro mais antigo da cidade, e continuava a se desenvolver sem um planejamento adequado, pois as casas não obedeciam a nenhum arruamento;

- Rói-Couro (constituía-se uma parte do que hoje é denominado bairro São Pedro e Centro). Era um bairro recente, que teve sua origem na construção de algumas barracas no período de 1944 a 1946. Estava localizado na parte baixa da margem direita do rio Branco. Nele se concentrava o maior número de olarias da cidade (Figura 48). As casas, em sua maioria, eram de taipas cobertas com palha de Buriti. 


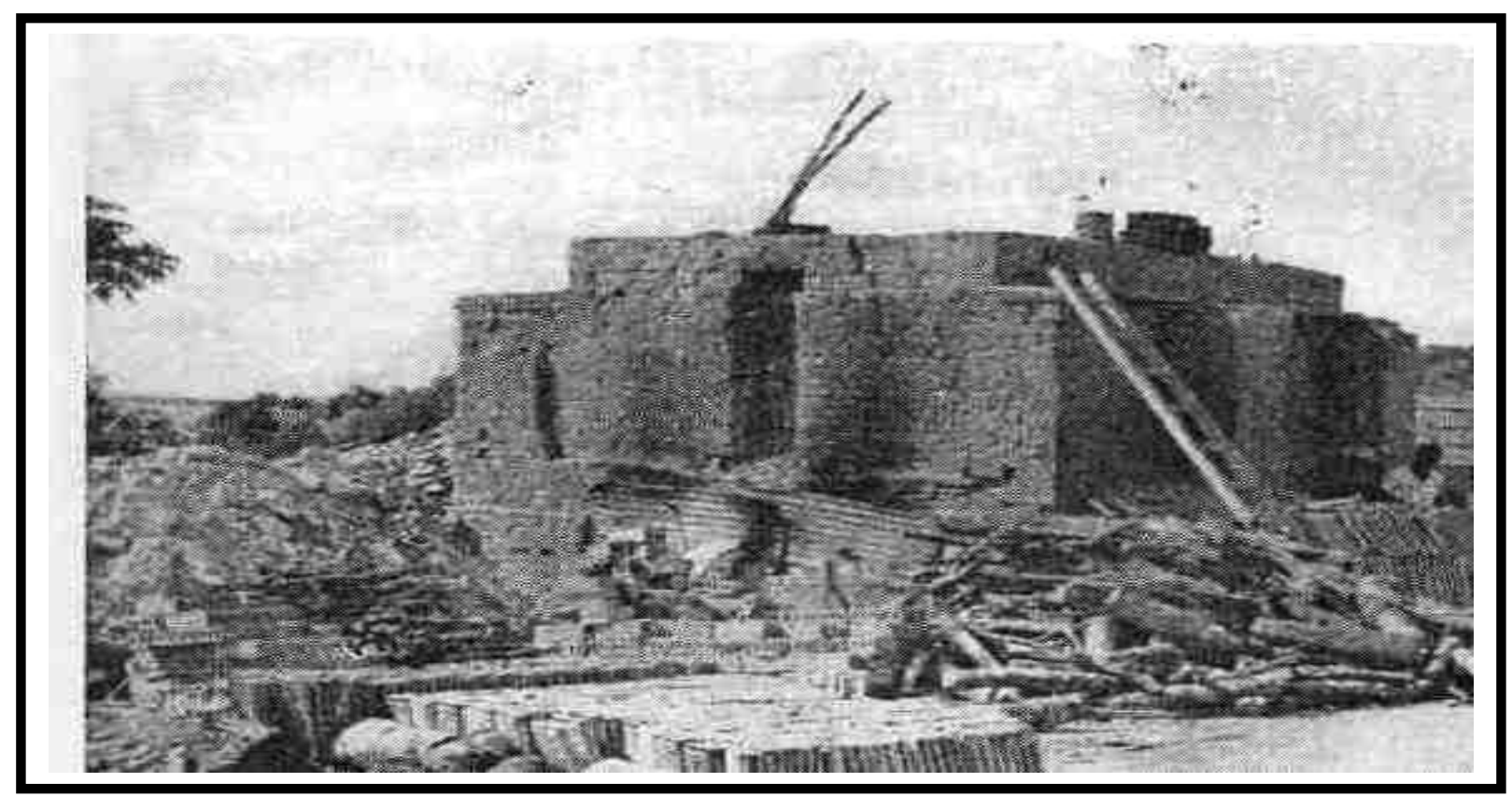

Figura 48: Olaria localizada no bairro Rói-Couro \Déc. 50

Foto: Acervo de Guerra, 1957

- Caxangá: (o bairro faz parte da atual área central da cidade) estava localizado no setor meridional da cidade, à margem do igarapé de mesmo nome. Era um bairro residencial;

- Centro: (é o bairro onde se localiza o setor comercial indutor da cidade hoje) considerado como o mais importante para a vida da cidade. Possuía pequenas casas comerciais de venda a varejo. No bairro, estava localizada a Avenida Jaime Brasil, artéria principal da cidade de Boa Vista, pois nela se concentrava a maioria das lojas comerciais. (Figura 49).

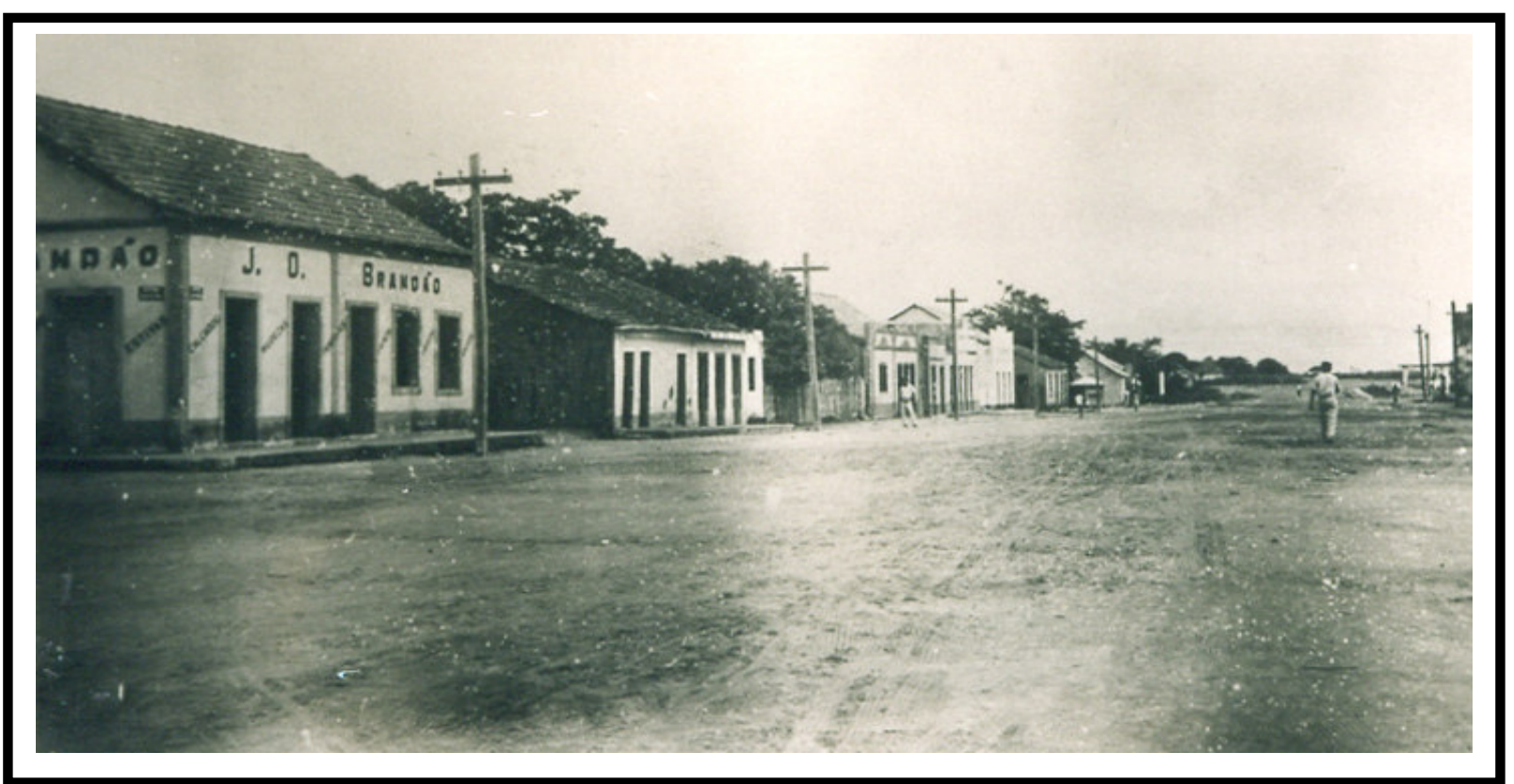

Figura 49: Avenida Jaime Brasil (Setor Comercial) \ Déc. 50

Foto: Acervo de Guerra, 1957 
No Centro, ao contrário dos outros bairros, as edificações eram de alvenaria cobertas de telha. A área compreendia entre as atuais Avenidas Castelo Branco, Sílvio Lofêgo Botelho, Bento Brasil e Coronel Mota, todas na confluência da Avenida Getúlio Vargas e delimitadas a sudeste com o rio Branco, constitui-se no núcleo embrionário de Boa Vista.

Digno de evidenciar é o fato de que na área central, as ruas eram bem traçadas face ao plano urbanístico. Todavia não possuíam calçamento e seu leito era de terra. Muitas tinham meios-fios e calçadas. Paralelamente, presenciava-se 0 surgimento de novos "bairros" no setor Oeste da cidade, que não apresentava nenhum padrão urbanístico (GUERRA, 1957).

- $\quad$ Praça da Bandeira: de acordo com a Séria Monográfica de Boa Vista (1987, p. 61), a Praça da Bandeira foi a designação genérica dada à área que se estendia da praça homônima até o bairro do Rói-Couro.

A circulação interna na cidade de Boa Vista era feita a pé ou por carro de aluguel, cujo número era relativamente grande, não existia transporte coletivo. (GUERRA, 1957, p. 144).

Já para o ex-governador José Maria Barbosa (1958, p. 19-21) que permaneceu no cargo de 1956 a 1959, o então Território vivia em um campo de luta política. Havia dificuldades em dotar o Território e a cidade de Boa Vista de equipamentos e serviços. Como expressa em entrevista cedida a Freitas (1993, p. 120).

\begin{abstract}
Foi difícil governar o território naquela época. As condições eram realmente muito ruins, especialmente no que se refere aos problemas de pessoal, material e principalmente político [...] a grande distância do território em relação os centros administrativos, comerciais e políticos de maiores recursos. A falta de mão-de-obra especializada e de indústria que fornecesse material de construção, saúde entre outros com melhor qualidade.
\end{abstract}

Comungando com Barbosa (1993), o ex-governador Djacir Cavalcante de Arruda (1961, p. 28-30) afirmava que o setor de transporte era o mais sério de todos os problemas da região e do qual dependia a solução dos demais na dinâmica de produção do espaço urbano de Boa Vista, uma vez que a região ainda era marcada pelo o isolamento do Território em relação ao restante do país. 
Desta maneira, a relação entre as ações dos ex-governadores, acima mencionadas, não foram unidirecionais, mas recíproca -, devido à própria natureza dialética das ações. Para Trindade Jr (1997, p. 10) essas ações estão em constante transformação face as necessidade da sociedade.

Desta forma, seja qual for à forma de ação, entre as variáveis ou dentro delas, não se pode perder de vista o conjunto, o contexto. Uma vez que o espaço está em evolução constante e resulta da ação de fatores externos e internos (SANTOS, 1985, p. 15).

A cidade, neste caso, é constituída por essa metamorfose, por estas ações múltiplas: o poder da concentração, a multiplicação das possibilidades, dos recursos, dos conflitos e do progresso (BEAUJEU-GARNIER, 1997, p. 47).

Com o golpe militar de março de 1964, os três Territórios Federais do país Amapá, Rondônia e Roraima, passaram a ser administrados pelas Forças Armadas: Exército, Marinha e Aeronáutica, respectivamente. No caso do Território Federal de Roraima, os governadores eram do comando da Aeronáutica. Com isso, a capital Boa Vista, transformou-se em uma "Base Aérea".

Esta decisão do Governo Central favoreceu a permanência dos governadores por mais tempo na administração dos territórios. Com isso, as ações eram planejadas e os resultados de certa forma obtidos, porém sob o comando militar.

A abertura da estrada Manaus - Boa Vista, a instalação de telefone público, a televisão, o telex, o correio, o avião a jato, as pontes de concreto, o Banco, a luz, a perimetral Norte cortando o território, os Batalhões do Exercito, a Base Aérea, o Aeroporto Internacional, foram ações que se concretizaram no Território a partir do golpe de 1964 (FREITAS, 1993, p. 163).

Com a posse do Marechal Artur da Costa e Silva em 1967 na Presidência da República, o Território Federal de Roraima passa a ser governado pelo TenenteCoronel Hélio da Costa Campos. O respectivo Tenente-Coronel exerceu o cargo de governador por duas vezes. No período de 1967 a 1969 e de 1970 a 1974.

Em sua gestão, a SUDAM elegeu, em 1968, a cidade de Boa Vista como "Pólo Estratégico de Desenvolvimento". Assim, a cidade passou a incorporar ações visando à humanização da população. 
Para Campos (1971. p. 12),

Com o volume crescente de recursos financeiros recebidos pelo governo, e o controle do Ministério do Interior - órgão controlador dos territórios, pode o governo iniciar a remodelação do controle administrativo, principalmente nas suas finanças e agora com o controle de material, iniciando uma programação baseada no planejamento, para atingir o objetivo.

Com os recursos disponíveis na década de 70 , criou a Centrais Elétricas de Roraima S.A - CER. Incentivando-a, a dar suporte técnico aos primeiros empreendimentos industriais primários, como indústria madeireira, artefatos de concreto, fábrica de refrigerante e a criação do frigorífico (CAMPOS, 1971, p. 60)

Essas iniciativas, de acordo com o Diagnóstico Sócio Econômico preliminar de Roraima de 1973, elaborado pela Associação de Crédito e Assistência Rural $\mathrm{RR} \backslash \mathrm{ACAR}$, promoveu na década de 50 e 60 do século $\mathrm{XX}$, um aumento da participação urbana em relação ao total de habitantes do território, passando de 28,32\% em 1950 para 43,12\% em 1960[...]. Esse crescimento urbano parece ser resultado da implantação definitiva de infra-estrutura administrativa na capital Boa Vista pelos governadores. Essa infra-estrutura administrativa exercia grande poder de atração em função do setor de serviços [...]. O município de Boa Vista contribuiu com $89,1 \%$ para a população do território, sendo que a capital Boa Vista concentrava $40,9 \%$ da população total.

Com a concentração sócioespacial na área central, os gestores públicos passaram a adotar ações voltadas para a promoção de novos espaços urbanos por meio de doações de lotes à população, privilegiando o entorno da área central da cidade e os espaços de alto status do setor Leste da cidade. Vale enfatizar que, apesar dessa política de doações de lotes urbanos, o gestor público não impediu a ocupação irregular de áreas de risco por pessoas oriundas das áreas de assentamento rurais, de garimpos e migrantes.

Nesta instância espacial, a estrutura do espaço urbano de Boa Vista era formada por estruturas demográficas, econômicas e financeiras, agentes diretos da dinâmica de produção da cidade (SANTOS, 1985, p. 16), onde a promoção do espaço estava vinculada a uma ferramenta da ação política que constroem formas, funções estruturas e desenvolve processos, que vão (re) produzir novas configurações sócioespaciais na cidade. 
Como assevera, Campos Filho (2001: 32-33),

O espaço urbano resulta de um processo de desenvolvimento social, no qual diferentes atores e agentes sociais desempenham seus papéis, cada qual marcando sua intervenção, de acordo com seus próprios interesses e objetivos. Estes atores são, fundamentalmente, as classes dominantes, as classes dominadas e o Estado.

Com isso, as transformações sócioespaciais na cidade de Boa Vista, iam acontecendo por meio das atividades produtivas e da população, materializadas espacialmente enquanto forma de desenvolvimento urbano, em diferentes níveis e escalas, seriam resultantes tanto da lógica da ação do Estado, de distintos capitais (empresas), quanto das estratégias de localização da força de trabalho (LIMONAD, 1999, p. 84).

A área ocupada na cidade até 1970 ainda era pequena. No entanto alguns bairros de Boa Vista vão sendo criados e implantados em forma de conjuntos habitacionais, ocupações irregulares e de loteamentos. Esta dinâmica intra-urbana foi uma das preocupações que o Governo Ramos Pereira tentou ordenar em conjunto com o prefeito Júlio Martins.

Ao assumir o governo em abril de 1974 até 1979, o Coronel Aviador Fernando Ramos Pereira, que seguia fielmente o Plano de Governo do Presidente Ernesto Geisel para as cidades Amazônicas: OCUPAR PARA DESENVOLVER e, finalmente, INTEGRAR (FREITAS, 1993, p. 184). Procurou resolver essa questão de forma planejada.

Conforme Freitas (1993:190),

$\mathrm{Na}$ área de Boa Vista, por exemplo, ele mandou elaborar, por sugestão dos idealizadores da planta da cidade: Capitão Êne Garcez dos Reis e Doutor Darcy Aleixo Derenusson, um plano de expansão urbana da cidade para que ela crescesse de modo ordenado e com a mesma beleza que caracteriza Boa Vista. Esse plano, concluído, ao tempo que fui o Prefeito Municipal de Boa Vista, previa a criação de novos bairros residenciais, com detalhes, não apenas do sistema viário, como também dos sistemas de abastecimento de água e de Energia elétrica, áreas de lazer, etc. Esse plano foi entregue ao meu sucessor e depois esquecido. Ficou como lembrança, apenas o conjunto do BNH-Pricumão que tem um estilo urbanístico ímpar, desde o arruamento até a própria locação das residências, onde até as alamedas receberam nomes de flores ao invés da tradicional denominação com os nomes de pessoas. Este plano urbanístico desapareceu. 
Sempre visando o desenvolvimento do Território e da capital Boa Vista, o governador Ramos Pereira, construiu a Estação Rodoviária Internacional de Boa Vista, o Palácio da Justiça, o Centro Social Urbano Valério Magalhães [...], investiu na área habitacional, construindo dois conjuntos habitacionais, um no bairro de São Vicente com 114 casas e, outro, no bairro Mecejana com 216 casas. Este último concluído no Governo Otomar Pinto [...]. Também construiu o conjunto residencial denominado "Conjunto dos Executivos" (Residências dos Secretarios de Governo) no bairro Canarinho (FREITAS, 1993, p.190-191).

Em 1973, por solicitação da prefeitura, a Fundação João Pinheiro de Belo Horizonte re-estudou o plano da cidade, mas somente com objetivos de tráfego. Paralelamente, surgiam, no setor Oeste da cidade, os conjuntos habitacionais oriundos de programas governamentais, ao mesmo tempo em que havia a "doação" de lotes urbanos e ocupações irregulares próximas ao rio Branco.

Em relação à construção do espaço urbano, o programa de ação do governo Ramos Pereira para o período de 1974 a 1979, visava em linhas gerais:

- Implantar um plano de desenvolvimento urbano de Boa Vista, consolidando os recursos federais destinados ao desenvolvimento urbano;

- Modernizar e reaparelhar o setor público do território, a fim de aprimorar suas funções produtoras de desenvolvimento;

- Capacitar os recursos humanos para as atividades do setor público e privado;

- Melhorar as condições de saúde da população de Roraima; e

- Regularizar o abastecimento urbano de água, energia entre outros, da capital do território (JORNAL BOA VISTA, 1976, p. 03)

$O$ solo urbano era usado predominante para fins residenciais, estando os prédios públicos localizados na área central. O centro comercial era incipiente, com uma concentração ao longo da Avenida Jaime Brasil.

O setor industrial limitava-se a pequenas indústrias de produtos alimentícios, madeiras, olarias, construção civil e arte, distribuídas indiscriminadamente pela cidade. 
O poder público continuava sendo o maior empregador e o setor de comércio refletia $O$ isolamento da área em relação ao restante do país (TERRITÓRIO FEDERAL DE RORAIMA, 1975, p. 53-59).

Para amenizar a situação, supramencionada, o prefeito Júlio Augusto Magalhães Martins, em 03 de setembro de 1976, sancionou a Lei № 42\76, que dispõe sobre o Plano de Urbanismo e Zoneamento de Boa Vista, juntamente com a Primeira Coletânea de Códigos do Município, em 1977. As Leis tinham por objetivo disciplinar o uso e ocupação do solo urbano.

Para efeito de regulação do uso, da ocupação e da utilização do solo urbano, a cidade de Boa Vista ficou dividida nas seguintes zonas: Zona Residencial (ZRI); Zona Residencial de Alta Densidade (ZR1); Zona Residencial de Média Densidade (ZR2); Zona Residencial de Baixa Densidade (ZR3); Zona de Depósito e Comércio Atacadista (ZD) Zona Administrativa (ZA); Zona Comercial (ZC) e a Área Institucional (AI). Como evidencia o Mapa 10 (TERRITÓRIO FEDERAL DE RORAIMA, 1977, p. 400).

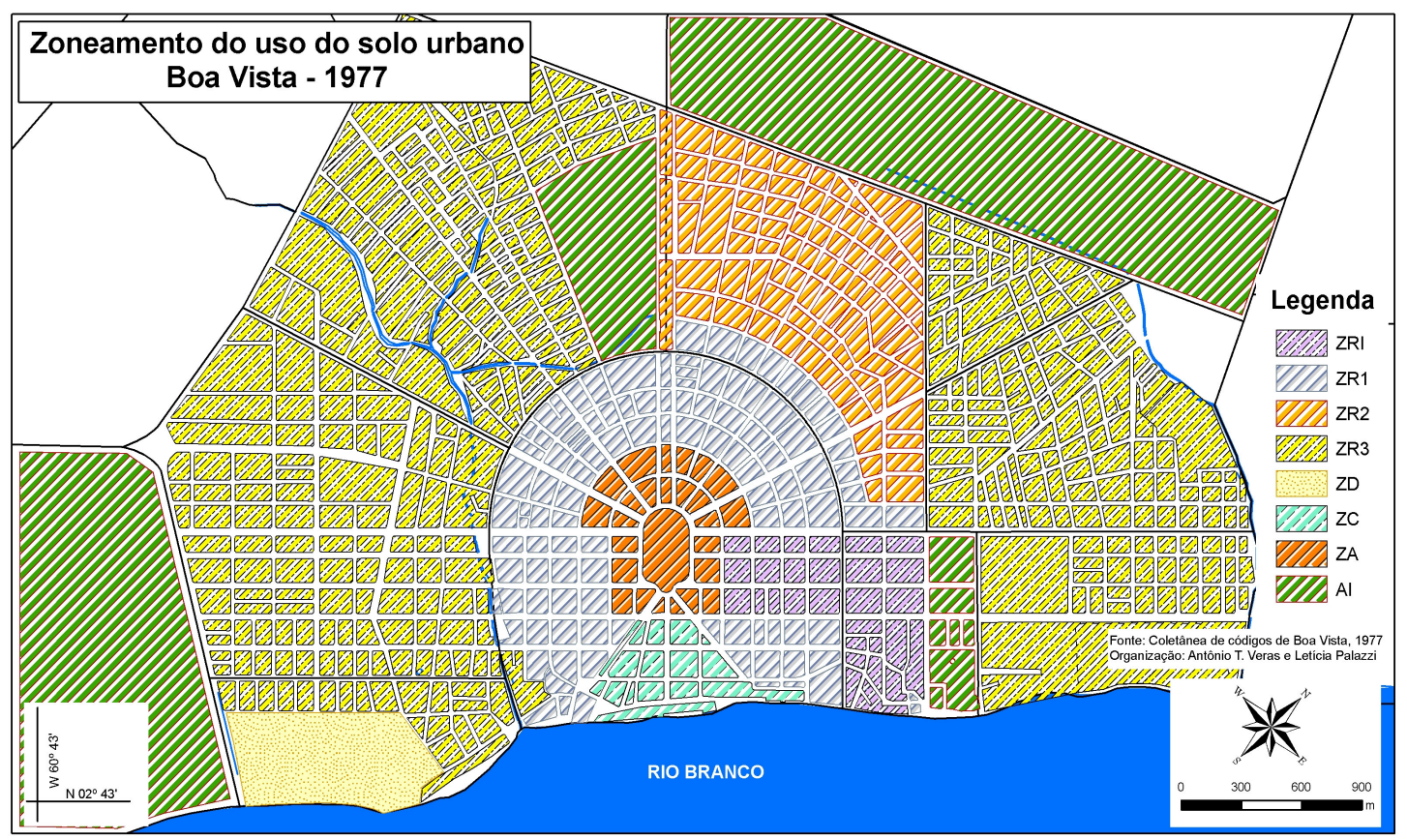

Mapa 10: Zoneamento de uso e ocupação do solo urbano de Boa Vista \} 1 9 7 7 .

Fonte: TERRITÓRIO FEDERAL DE RORAIMA, 1977 
Percebe-se que a ação urbanística do governo Ramos Pereira e do Prefeito Júlio Martins, confronta-se com a necessidade de mudanças na forma e estrutura da cidade de Boa Vista, em que o direito à cidade transforma-se num privilégio de pequena parcela da população, e as alterações introduzidas vão adequar a cidade a uma nova realidade.

Para Arrais (2001, P. 183) esse direito à cidade é também o direito de beneficiar-se enquanto obra, de construir e consumir o ambiente urbano, de freqüentar suas praças, passeios públicos, ruas entre outros.

Desta forma, segundo Carlos (2007, p. 69)

O desenvolvimento das forças produtivas produz mudanças constantes e,
com essas, a modificação do espaço urbano. Essas mudanças são hoje cada
vez mais rápidas e profundas, gerando novas formas de configuração
espacial, novo ritmo de vida, novo relacionamento entre as pessoas, novos
valores.

A produção do espaço urbano de Boa Vista na gestão de Ramos Pereira se explica, em grande parte, pela estrutura produtiva, pelas ações do poder público e por fatores que permeiam esses processos. Neste contexto, as relações de produção se manifestam através dos conflitos e contradições inerentes à sociedade. Tais conflitos e contradições estão vinculados à divisão territorial do trabalho, à distribuição de renda, ao acesso à infra-estrutura, aos serviços e bens de consumo.

É nesse contexto que vão se redefinindo os agentes produtores e consumidores da estrutura espacial da cidade de Boa Vista, confrontando-se com novos atores, que ora se encontram de maneira concentrada, ora de forma dispersa, ocasionando a fragmentação intra-urbana, em que se processam os diferentes padrões de acumulação, produção e circulação da cidade.

Com a saída de Ramos Pereira, em 1979, assume o governo o Brigadeiro Ottomar de Souza Pinto, que iria administrar o Território até a criação do Estado de Roraima em 1988, seria o penúltimo governo sob o comando da Aeronáutica. Vale ressaltar que, no fim da fase em que o território era governado por oficiais da Aeronáutica - que vai do ano de 1964 até o ano de 1983 -, o Território foi governado, ainda, por 6 (seis) governadores. Seu mandato teve início no ano de 1979 e durou até o ano de 1983. Tinha como prefeito o Senhor Rodolfo Abrahim. 
Na acepção de Silva (2007, p. 214)

A expansão da cidade nesses períodos se deve principalmente às iniciativas dos dois períodos do governo Ottomar de Souza Pinto entre 1979 e 1983 e entre 1991 e 1995 intercalado pelo governo de Romero Jucá, entre 1987 e 1989, quando estes estimularam o surgimento de novos bairros com uma política de incentivo migratório. Os resultados não foram somente 0 movimento para o interior em busca de lotes rurais, mas também de lotes urbanos e das vantagens de uma vida urbana proporcionada pela capital [...] A expansão urbana de Boa Vista, após a década de 1980, dá-se quando novas áreas foram progressivamente incorporadas mediante a proliferação de novos loteamentos, produzidos de forma descontrolada e sem infraestrutura, respondendo especialmente a interesses políticos de assentamentos de migrantes que eram induzidos a se deslocarem para Boa Vista.

Seu governo era centralizador $e$ as suas ações sempre estavam condicionadas aos seus interesses próprios e político. Incentivou a migração de pessoas da região Nordeste e do Centro-Sul para o Estado, visando formar currais eleitoreiros. Fez doações de lotes urbanos em Áreas de Proteção Permanentes APP's, criou conjuntos habitacionais, em particular, o conjunto Pintolândia que era o seu maior reduto eleitoreiro em Boa Vista.

Quando assumiu o governo, teve como meta principal impulsionar a agropecuária e incentivar a migração com o objetivo de ocupar os espaços vazios no Território.

Porém o que se viu nessa política foi um verdadeiro descaso com o pequeno produtor rural. Pois os assentados não permaneciam por muito tempo em seus lotes por falta de apoio logístico do governador, tendo como conseqüência a emigração dessa população para a cidade de Boa Vista. Ao chegarem, não tinham onde morar, o que os obrigava a ocupar irregularmente terrenos insalubres. Foram criados, assim, periferias de autoconstrução em Boa Vista, isto é, novos modelos de segregação apareceram impulsionados pelos diferentes agentes da organização espacial urbana, em particular, pelos proprietários fundiários e o Estado.

Visando favorecesse dessa dinâmica intra-urbana, o governador Ottomar de Souza Pinto, no ano de 1980, criou uma Comissão de Apoio a Prefeitura Municipal de Boa Vista, ligada a Coordenação da Secretaria de Planejamento do Governo de Roraima, para elaborar um diagnóstico sócio-econômico de Boa Vista com o objetivo de engajar os anseios da sociedade as metas governamentais, e, ao mesmo tempo, auxiliar a prefeitura nos trabalhos de urbanização da cidade. 
De acordo com o diagnóstico, o município de Boa Vista concentrava aproximadamente $85 \%$ do contingente populacional do território, como mostra a Tabela 1, sendo a cidade de Boa Vista o principal núcleo urbano polarizador do Alto Rio Branco por concentrar o melhor aparelhamento de infra-estrutura regional (SEPLANIRR,1980, p. 21).

\begin{tabular}{l|cccc}
\hline \multicolumn{1}{c|}{ Município } & Ano 1950 & Ano 1960 & Ano 1970 & Ano 1980* \\
\hline Boa Vista & $\mathbf{1 7 . 2 4 7}$ & $\mathbf{2 4 . 1 2 6}$ & $\mathbf{3 6 . 4 6 4}$ & $\mathbf{6 3 . 6 1 9}$ \\
Urbana & 5.132 & 10.002 & 16.727 & 40.644 \\
Rural & 12.115 & 14.124 & 19.737 & 22.975 \\
\hline
\end{tabular}

Tabela 1: Evolução da população do município de Boa Vista \1950-1980

* Dados sujeitos a retificação

Fonte: Fundação IBGE. Anuário Estatístico - 1979

No que concerne a distribuição espacial da população, a mesma, estava dividida por zonas ou por bairros.

a) A Zona 1 - Bairro Centro;

b) A Zona 2 - Bairro Centro;

c) A Zona 3 - Bairro São Vicente e 13 de Setembro;

d) A Zona 4 - Bairro Jardim Floresta e Mecejana;

e) A Zona 5 - Bairro São Francisco, 31 de Março e dos Estados;

f) A Zona 6 - Bairro Aparecida, Canarinho e São Pedro;

g) A Zona 7 - Bairro Pricumã.

A pesquisa revelou que a Zona 3 (três) era a mais populosa, com $23 \%$ da população total, correspondia aos bairros de São Vicente e 13 de Setembro, seguida da Zona 6 (seis), com 19,9\%, que compreendia os bairros Aparecida, Canarinho e São Pedro e posteriormente a Zona 5 (cinco), com 18,5\% que correspondia aos bairros, de São Francisco, 31 de março e dos Estados, como mostra a Tabela 02 e o Mapa 11 (SEPLANIRR, 1980, p. 28). 


\begin{tabular}{|c|c|c|c|c|c|}
\hline \multirow{2}{*}{ Zona(s) } & \multirow{2}{*}{$\begin{array}{c}\text { Número } \\
\text { De } \\
\text { Famílias }\end{array}$} & \multicolumn{2}{|c|}{ População } & \multirow{2}{*}{ Área } & \multirow{2}{*}{$\begin{array}{l}\text { Densidade } \\
\text { Hab. } \mathrm{Km}^{2}\end{array}$} \\
\hline & & Hab. & $\%$ & & \\
\hline 1 & 1.071 & 5.649 & 13,9 & 1.225 & 4.611 \\
\hline 2 & 932 & 4.918 & 12,1 & 1.225 & 4.014 \\
\hline 3 & 1.772 & 9.348 & 23,0 & 5.340 & 1.750 \\
\hline 4 & 894 & 4.715 & 11,6 & 5.840 & 807 \\
\hline 5 & 1.426 & 7.520 & 18,5 & 2.910 & 2.584 \\
\hline 6 & 1.534 & 8.088 & 19,9 & 2.720 & 2.973 \\
\hline 7 & 77 & 406 & 1,0 & 6.270 & 65 \\
\hline Total & 7.706 & 40.644 & $100 \%$ & 25.530 & - \\
\hline
\end{tabular}

Tabela 02: Distribuição espacial da população \} 1 9 8 0 Fonte: SEPLANIRR. 1980

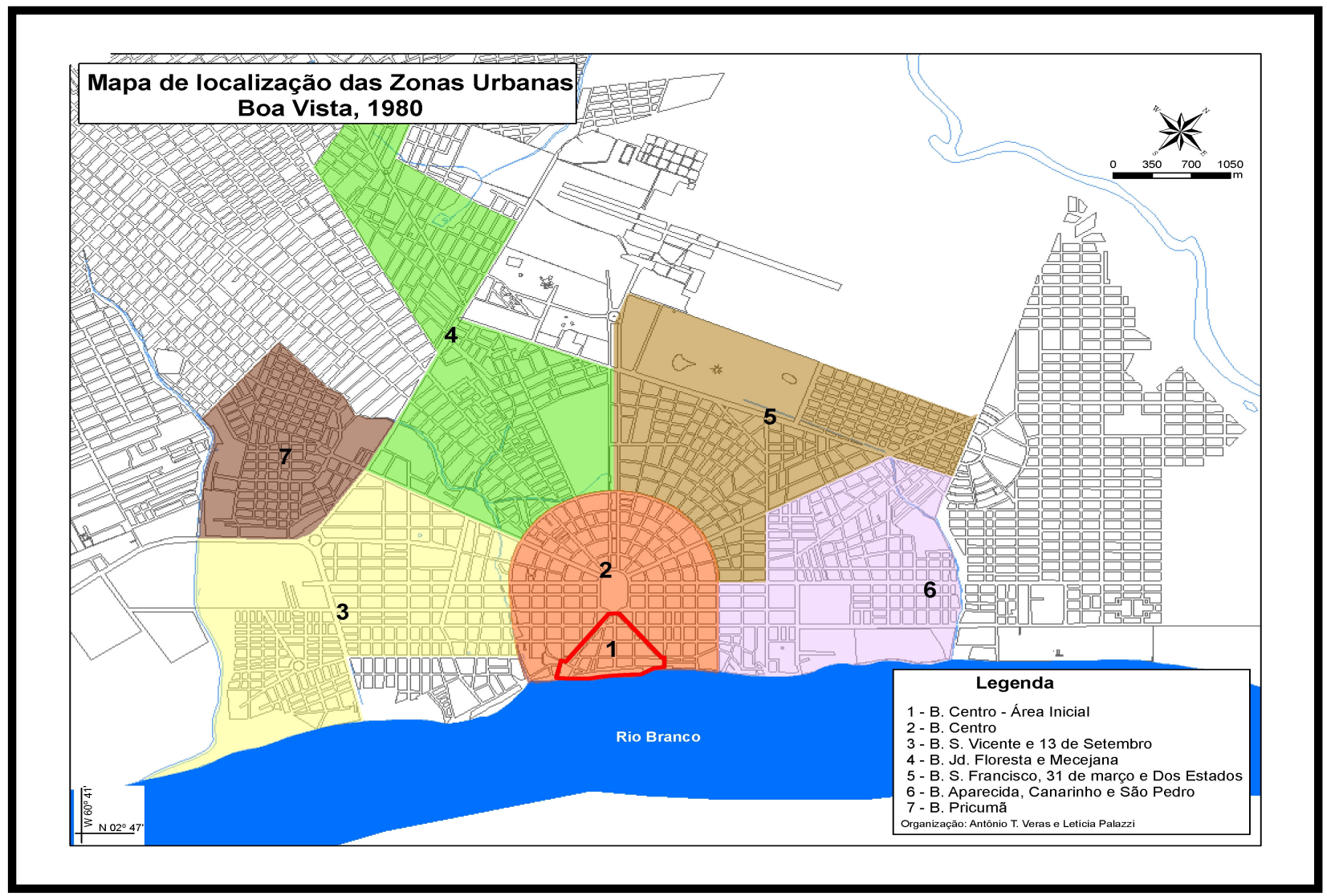

Mapa 11: Mapa de localização das zonas urbanas $\backslash 1980$

Fonte: SEPLAN \RR. 1980. 
No que tange a distribuição espacial por bairro, o Centro apresentava-se como o mais populoso, com $26 \%$ da população total. Seguido pelos bairros São Vicente com 15,3\% e Aparecida com 12,2\%. Como mostra a Tabela 03.

\begin{tabular}{|c|c|c|c|c|c|c|}
\hline \multirow{2}{*}{ Bairro(s) } & \multirow{2}{*}{$\begin{array}{l}\text { Número } \\
\text { de } \\
\text { Famílias }\end{array}$} & \multicolumn{2}{|c|}{ População } & \multirow[b]{2}{*}{ Área $\mathrm{Km}^{2}$} & \multicolumn{2}{|c|}{ Densidade } \\
\hline & & Hab. & $\%$ & & $\mathrm{Hab} . \mathrm{Km}^{2}$ & Hab.IHa \\
\hline Centro & 2.003 & 10.567 & 26,0 & 2,45 & 4.313 & 43,13 \\
\hline São Vicente & 1.179 & 6.219 & 15,3 & 3,25 & 1.913 & 19,13 \\
\hline 13 de Setembro & 593 & 3.129 & 7,7 & 2,09 & 1.497 & 14,97 \\
\hline Jardim Floresta & 254 & 1.341 & 3,3 & 3,14 & 427 & 4,27 \\
\hline Mecejana & 640 & 3.374 & 8,3 & 2,70 & 1.249 & 12,49 \\
\hline São Francisco & 747 & 3.943 & 9,7 & 1,68 & 2.347 & 23,47 \\
\hline 31 de março & 254 & 1.341 & 3,3 & 0,32 & 4.190 & 41,90 \\
\hline Dos Estados & 425 & 2.236 & 5,5 & 0,91 & 2.457 & 24,57 \\
\hline Aparecida & 940 & 4.958 & 12,2 & 1,09 & 4.548 & 45,48 \\
\hline Canarinho & 155 & 813 & 2,0 & 1,08 & 753 & 7,53 \\
\hline São Pedro & 439 & 2.317 & 5,7 & 0,55 & 4.213 & 42,13 \\
\hline Pricumã & 77 & 406 & 1,0 & 6,25 & 65 & 0,65 \\
\hline Total & 7.706 & 40.644 & $100 \%$ & 25,53 & - & - \\
\hline
\end{tabular}

Tabela 03: Distribuição espacial da população por bairro \1980

Fonte: SEPLANIRR. 1980

No que concerne ao saneamento básico, a rede de distribuição de água abrangia uma faixa de $170 \mathrm{~km}$ de extensão, beneficiava aproximadamente $80 \%$ da população da cidade [...]. Paralelamente, o sistema de esgoto atendia a $26 \%$ da população da cidade, por meio de quase 2.000 ligações prediais localizadas na área central (Mapa 12) (SEPLANIRR, 1980, p. 35-40). 


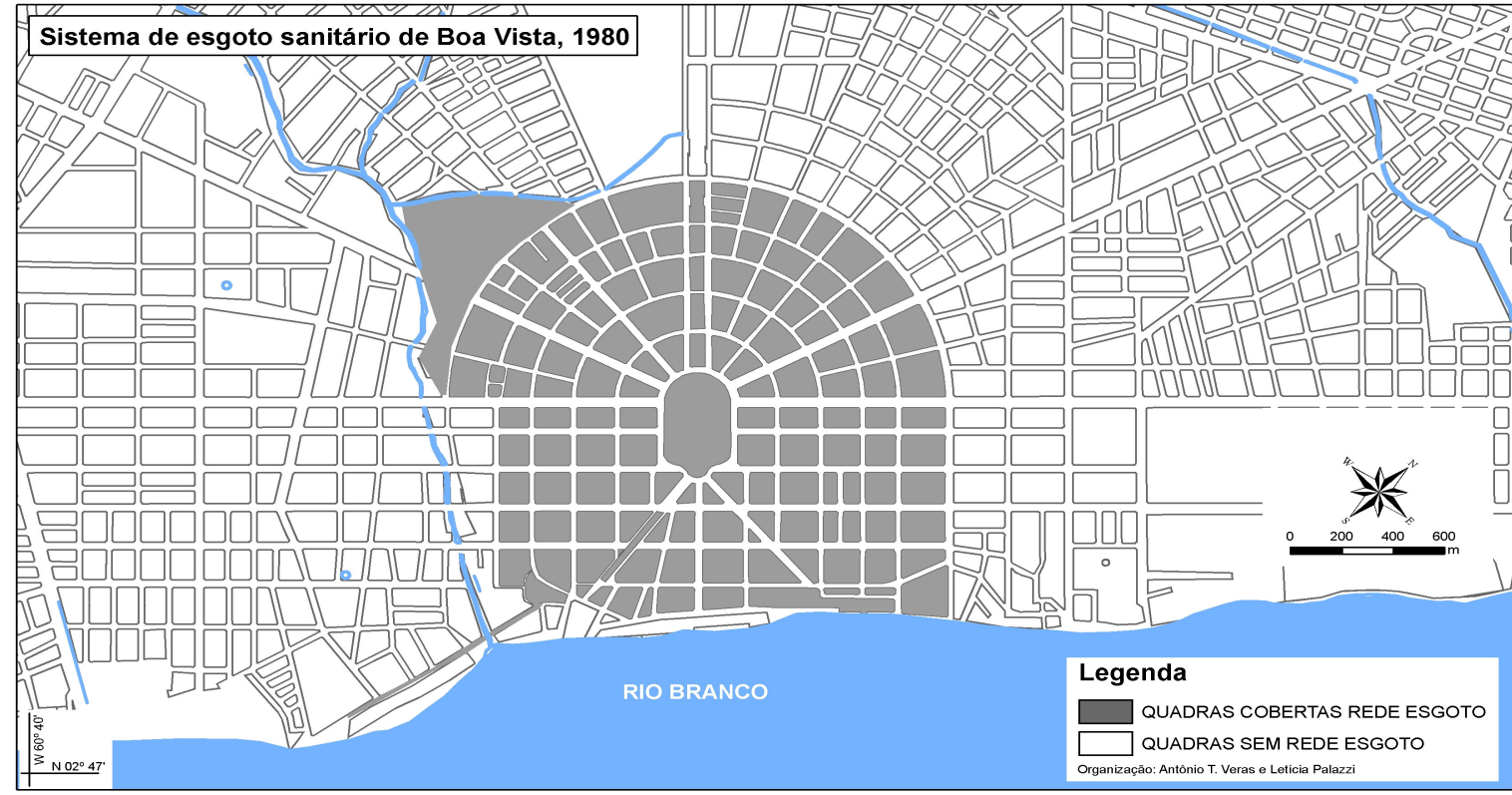

Mapa 12: Sistema de esgoto sanitário de Boa Vista $\backslash 1980$

Fonte: SEPLAN \RR. 1980.

Quanto ao setor de habitação, a questão estava relacionada com o baixo índice de regularização dos lotes, ocasionado pela situação peculiar jurídica do Território Federal. Para solucionar o problema, segundo a SEPLANIRR, (1980, p. 76), foi criado em 1979 o Conselho Imobiliário Territorial, que tinha como objetivo principal regularizar os lotes urbanos, com emissão de títulos definitivos de propriedade.

Com base nesse estudo, a SEPLAN, traçou uma estratégia de desenvolvimento urbano com o objetivo de reordenar o espaço urbano e propor uma nova integração urbana na área central ${ }^{24}$.

${ }^{24}$ Sendo Boa Vista uma cidade que se desenvolveu a partir de um plano de desenho bastante claro e
compreensível, a apropriação do espaço urbano se fez claramente em função de certos "marcos" que
caracterizam determinadas áreas [...] assim sendo, foi questionada a retomada do sistema radial
concêntrica, numa análise crítica com sentido prospectivo. O plano rádio-concêntrico de 1945 é a
configuração de uma situação na qual o poder está centralizado, geometricamente na trama urbana,
de onde partem todas as forças indutoras do crescimento da cidade. Próximo a essa área central
administrativa, se desenvolve o comércio local. Essas funções polarizam todas as atividades urbanas,
gerando assim fluxos que tendem a congestionar as áreas centrais. Esse sistema tem como vias
principais as radiais que partem do centro e se prolongam para acompanhar o crescimento da cidade.
Esta estrutura, embora seja admissível para a cidade de pequeno porte e tenha uma conformação
imponente, apresenta alguns problemas, como: a) ao se afastarem do centro as radiais se distanciam
entre si, criando a necessidade cada vez maior de vias locais de curto percurso e aumentando a 
Desta maneira, percebe-se que a dinâmica urbana de Boa Vista dava-se na área central, e os processos de ocupação e uso do solo urbano era resultado da intrusão da sociedade nessas formas e objetos, por isso esses objetos não mudaram de lugar, mas mudaram de função, de significado e de valor sistêmico por meio do seu uso, sendo assim um conjunto de mercadorias, cujo valor individual é função do valor que a sociedade, em um dado momento, atribui a cada pedaço de matéria, a cada fração da paisagem.

Assim, o gestor público passa a investir em infra-estrutura nas áreas valorizadas pelos especuladores, expressando espacialmente as desigualdades sócioespaciais (SALES,2005, p. 34).

Por isso, se justifica em parte a concentração de equipamento e serviços na área central da cidade. Pois, o centro funcionava como um agente indutor das atividades sócioespaciais da cidade.

Segundo o IBGE, (1981), na década de 80 do século XX, a cidade estava subdividida em 12 bairros, denominados de Jardim Floresta, dos Estados, São Francisco, 31 de Março, Aparecida, Canarinho, São Pedro, Centro, Mecejana, São Vicente, Industrial, e 13 de Setembro. Com relação ao uso do solo urbano, os equipamentos e serviços se concentravam na área central em virtude da integração urbana do centro com o restante da cidade (Mapa 13 e 14).

circulação em ziguezague b) possibilidade de certa estratificação dentro da trama urbana, uma vez que privilegia um único centro para o qual tudo converge $\mathrm{c}$ ) à medida que se aproxima das áreas centrais, eleva-se rapidamente a proporção das áreas consumidas pelo sistema viário e por conseqüência tem-se um baixo índice de aproveitamento dos terrenos. Considerando-se a impossibilidade de determinar o limite de crescimento de uma cidade e a tendência de permanência e ampliação do centro de interesse - Centro Cívico, administrativo e Comercial, acredita-se que esta estrutura viria causar problemas de solução onerosa no futuro, com relação ao congestionamento da área central. Assim é que se respeitou a hipótese de, respeitando a área urbanizada atual, buscar dotar a cidade de uma estrutura em aberto, que, impedindo a continuidade do traçado atual, venha abrir novas perspectivas para o desenvolvimento de Boa Vista. 


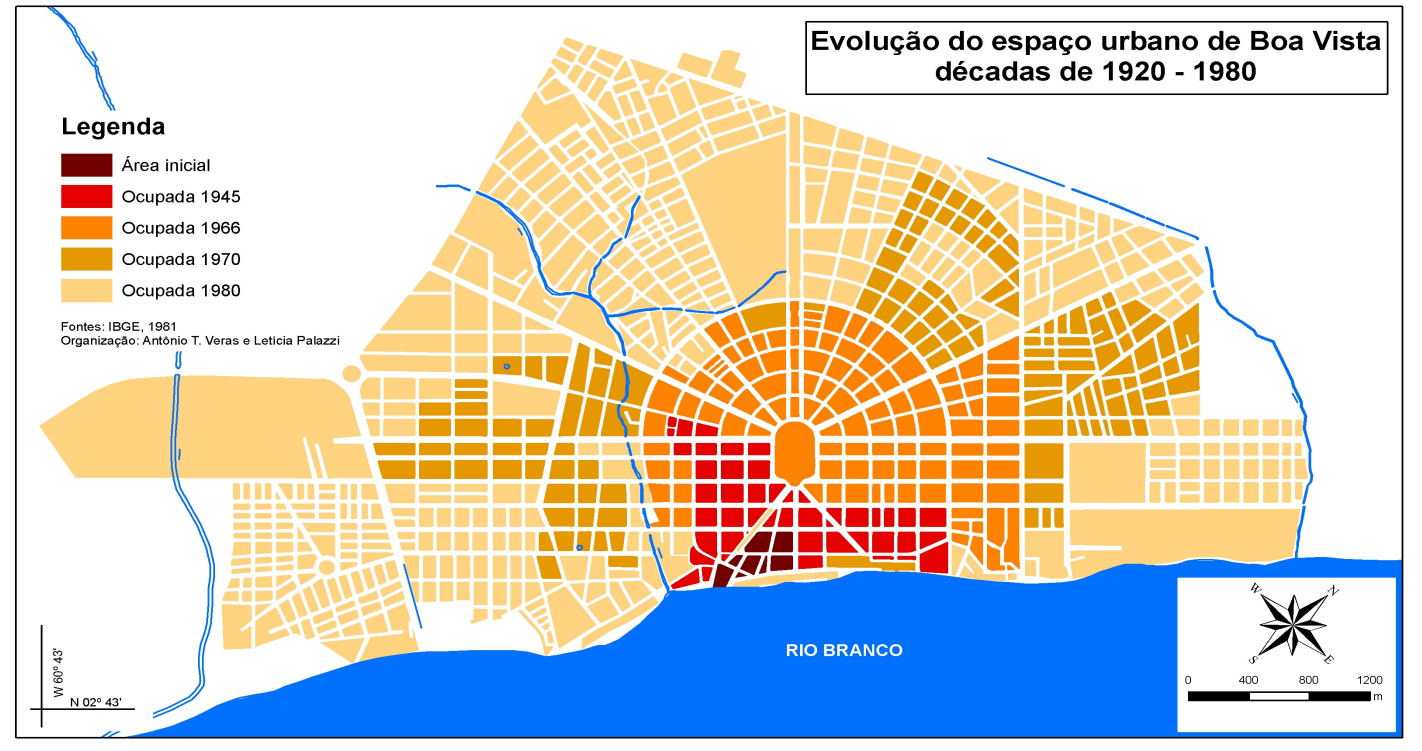

Mapa 13: Evolução do espaço urbano de Boa Vista \Décadas de 20 a 80 Fonte: IBGE, 1981.

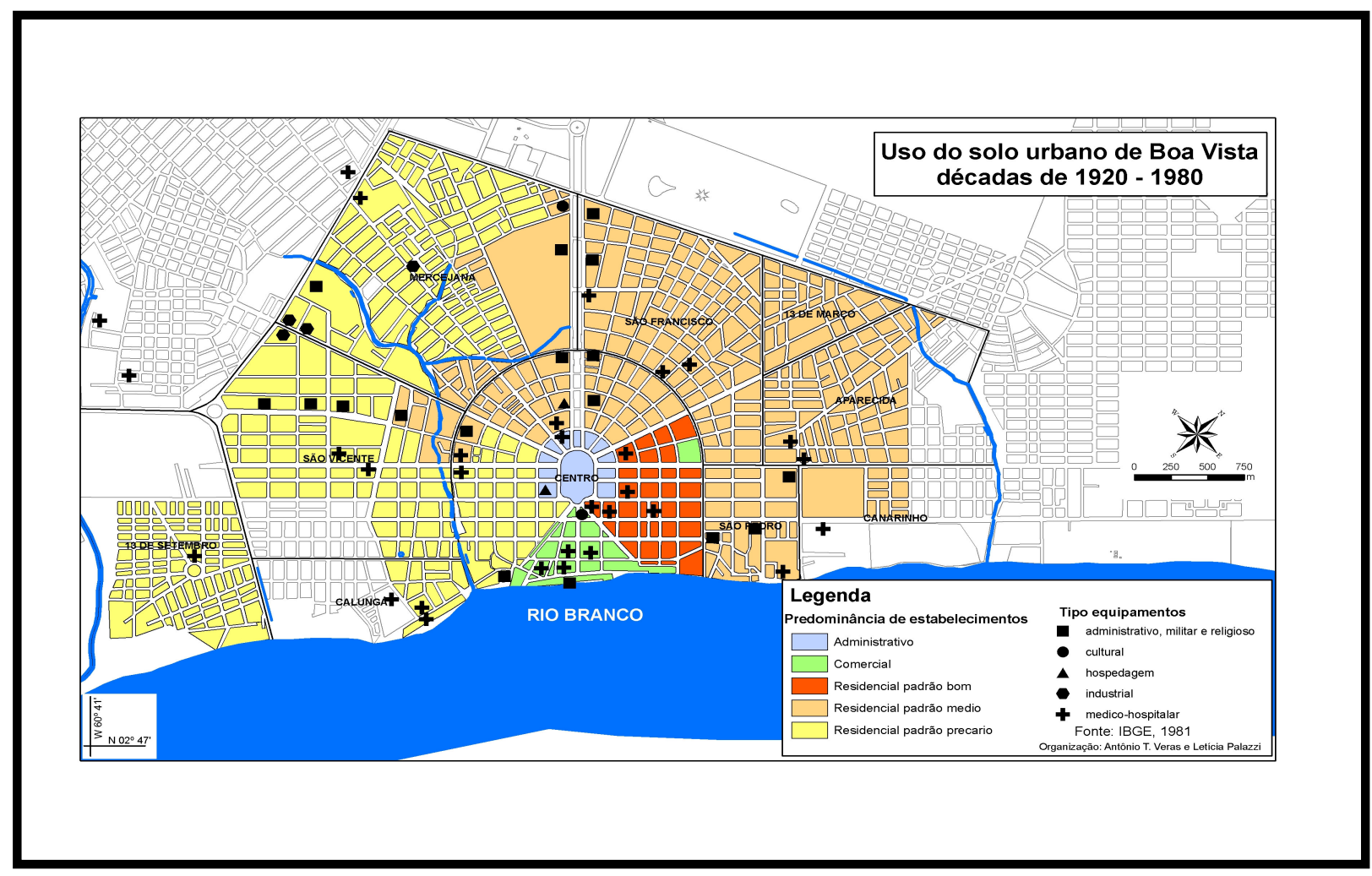

Mapa 14: Uso do solo urbano de Boa Vista \Déc. de 20 a 80 Fonte: IBGE, 1981. 
Outro fato a considerar na gestão Ottomar Pinto foi o movimento de ocupações irregulares que aconteciam na cidade, principalmente em terrenos desprovidos de infra-estrutura e pouco valorizados, em particular, as glebas situadas no setor Oeste da cidade. Esse movimento acarretou uma expansão urbana acelerada e desordenada para o referido setor.

Outra questão a ser exposta é que, durante o interstício como Território Federal do Rio Branco, e posteriormente Roraima, que vai de 1943 a 1988, o conjunto de ações e instrumentos utilizados para estabelecer as condições materiais visando ao desenvolvimento da produção, do consumo e da acumulação, assim como a reprodução de classes sociais e suas frações no espaço urbano de Boa Vista foram um instrumento de controle político e ideológico. Incorporados ao meio urbano por meio dos serviços públicos. Desta maneira, "o Estado se tornou mais transparente com relação a sua interferência e influência na organização e desenvolvimento da cidade, ou mais especificamente do espaço urbano" (MARINATO, 2000, p. 40-50).

Todas estas ações são alternativas do governo e que, segundo Corrêa (1989 Apud MARINATO, 2000, p. 40-50) "são recursos de ação marcados pelos conflitos de interesses dos diferentes membros da sociedade de classes, assim como da aliança entre eles, privilegiando, a cada instante, a cobiça da classe que está no poder".

Cabe esclarecer, também, que os instrumentos de produção de áreas saneadas e edificadas na cidade deram-se a partir de aterros de diversos terrenos. Esta ação do poder público em Boa Vista visava principalmente à criação de novas áreas passíveis de ocupação dentro da cidade e da necessidade de expansão territorial. Entretanto estas práticas foram utilizadas em diferentes momentos históricos, e a variedade de propósitos que desencadearam as obras dessa natureza foram os mais diversos e de extrema falta de planejamento e respeito ao meio ambiente natural de Boa Vista.

Um exemplo, segundo o relatório de análise da situação habitacional de Boa Vista elaborado pelo Instituto Brasileiro de Administração Municipal IBAM (2006, p. 1-32), foram os primeiros conjuntos residenciais, produzidos pelos governadores nas décadas de 70 e 80 destinados a funcionários públicos do antigo Território e aos militares que serviam na região. Estes conjuntos estão situados nos 
bairros mais próximos do Centro, em São Vicente, São Francisco, Aparecida, Mecejana e Pricumã.

Assim, as ações dos ex-governadores interferiram diretamente na diferenciação espacial da cidade e no processo de acumulação e reprodução das classes sociais, estando diretamente ligado ao processo de valorização e degradação das frações da cidade.

Conforme Silva (2007, p. 211)

Essa cidade da fronteira, enquanto ponto limite da soberania nacional, aproximava-se do poder central, por meio de interventores que regiam as administrações locais, produzindo sua história, ao longo da qual formas e funções vão sendo produzidas, refletindo processos específicos no âmbito nacional, regional e local e, em alguns casos, internacional, devido a sua posição limítrofe.

\title{
3.4 A criação do Estado de Roraima e sua importância na dinâmica urbana de Boa Vista
}

O período de 5 de outubro de 1988 a 31 de dezembro de 1990 é considerado de transição do Território Federal para o Estado.

Com a criação do Estado de Roraima em 1988, a cidade passa a ter uma autonomia em suas político-administrativas. O prefeito passa a ser eleito pelo o povo, e não indicado pelo governador. Desta forma, as políticas voltadas para o desenvolvimento urbano passam a ser condicionadas a planejamentos estratégicos, e sem a interferência do Governo Central.

De acordo com o COHRE (2005-2006:40)

\begin{abstract}
$\mathrm{Na}$ época da transformação do Território de Roraima em Estado, o processo de urbanização da cidade de Boa Vista foi acentuado. Neste período, ocorreu a inversão entre a população urbana e rural. Na década de 90, o índice de crescimento urbano de Boa Vista chegou a $4 \%$ ao ano e a taxa de urbanização passou de $78,04 \%$ para $98,27 \%$ entre 1991 e 2000 , crescimento que praticamente triplicou a área urbana.
\end{abstract}

As conseqüências deste quadro de urbanização rápida e intenso não poderiam ser outras: multiplicaram-se os bairros periféricos sem as mínimas condições de habitação, ocorreu uma ocupação desenfreada de áreas de proteção e de risco ambientais, houve um aumento da demanda por serviços públicos (escolas, hospitais, postos de saúde entre outros) e os índices de desemprego e informalidade alcançaram patamares elevados.

Para Barros (1995, p. 153) no período de transição e após a criação do Estado de Roraima, o poder público continuava com a política de doação de lotes gratuitamente nas áreas periféricas da cidade, que posteriormente foram transformados em bairro, como foi o caso do bairro Asa Branca. Enquanto isso, as 
ocupações irregulares prosseguiam em ritmo frenético em diferentes áreas da cidade. Para o autor, o período de 1987 a 1990, corresponde ao período do garimpo recente, sua desarticulação por parte do Governo Federal, provocou uma evasão de muitos moradores de Boa Vista, declínio no preço dos imóveis e centenas de habitações semi-acabadas, e fechadas, posto que a razão de permanência destes moradores garimpeiros em Boa Vista não mais existia.

Porém, segundo dados do censo do IBGE de 1991, independentemente da saída de parte dessa população garimpeira em 1990, o estado de Roraima possuía 215.790 habitantes. Destes, 142.813 habitantes estavam concentrados na cidade de Boa Vista (BARBOSA, 1993, p. 189). O que prova uma hiperconcentração populacional na respectiva cidade.

Esse fato alterou em parte a configuração sócioespacial de Boa Vista. Pois aumentou o número de habitantes - que não tendo onde morar, deslocavam-se para a periferia e ocupavam irregularmente os terrenos em área de risco (áreas inundáveis e próximas aos lagos e igarapés). Tendo início o surgimento de bairros suburbanos e às patologias sociais (miséria, crime, doenças entre outros) em decorrência da ausência de um planejamento urbano que viabilizasse melhores condições de vida para a população que se alojavam nessas áreas.

Desta maneira, tem-se a ocupação da terra urbana e dos recursos nela existentes, que continua a ser o motivo principal da expansão da cidade, sugerindo uma nova (re) conceituação da noção de propriedade. O rápido crescimento demográfico e a introdução de novas estruturas produtivas vão se processar através do mercado de terras urbanas, na medida em que o incremento da população e das atividades produtivas fará crescer radicalmente a demanda por terras na cidade. Este processo provocará mudanças na hierarquia dos preços fundiários, que irão, por sua vez, condicionar a localização das atividades e das pessoas no espaço, em função das respectivas capacidades de competição.

Surgem as novas categorias de profissionais; de agentes promotores do espaço urbano; e a conseqüente alteração nas relações de trabalho até então existente.

Já em 1989, quando assume a prefeitura de Boa Vista o Senhor Barac Bento, a cidade encontrava-ve sem um plano voltado para o desenvolvimento urbano. Assim, a cidade se expandia de forma desordenada, sem um planejamento urbano 
estratégico que possibilitasse uma orientação de uso e ocupação do solo urbano, em particular em respeito ao meio ambiente.

Nessa dinâmica espacial, o traçado urbano da cidade ia tomando novas formas em sua configuração espacial, resultando a princípio numa "favelização" na periferia da cidade. Essa desordem urbana induziu a prefeitura a elaborar um Plano Diretor para nortear uma política de desenvolvimento urbano, objetivando, dar condições de acesso aos equipamentos e serviços públicos a população, ou seja, promover o desenvolvimento urbano, zoneamento de uso e ocupação do solo, do sistema viário e parcelamento do solo.

Assim, a Prefeitura Municipal de Boa Vista - PMBV, em 1989, firmou contrato com a Prefeitura do Paraná, por meio do Instituto de Pesquisa Urbana de Curitiba para elaborar um Plano Diretor para a cidade de Boa Vista.

No entanto a lei № $244^{25}$, que dispõe sobre a promoção do desenvolvimento urbano, zoneamento, uso e ocupação do solo, sistema viário, parcelamento do solo e dá outras providências, só foi promulgada em 06 de setembro de 1991. Fato que contribui para retardar as políticas de desenvolvimento urbano da cidade.

De acordo com a Plano Diretor de Desenvolvimento Urbano de Boa Vista PDDU \BV (1991, p. 9) as linhas de ação do Plano visavam a:

- Estabelecer um plano global de expansão urbana, econômica, de ensino, capaz de atender os diferentes níveis educacionais;

- $\quad$ Elaborar diretrizes para a preservação da ecologia e do meio-ambiente; e

- Estabelecer um plano para a construção viária, ligando o centro da cidade de Boa Vista aos bairros;

Vale ressaltar que, na elaboração desse plano, não houve nenhuma consulta prévia a população, tão pouco uma leitura da cidade, que pudesse diagnosticar as necessidades por equipamentos e serviços da população no sentido de promover o desenvolvimento e o crescimento ordenado de Boa Vista.

Para o COHRE (2005-2006, p. 78) e o Instituto Brasileiro de Administração Municipal- IBAM (2006), este plano incorporava alguns avanços nos seus conteúdos, em especial nos conceitos pós-constituição relacionados ao

\footnotetext{
25 Maiores informações consultar: Plano Diretor de Desenvolvimento Urbano de Boa Vista PDDU\BV. Lei no 244, de 06 de Setembro de 1991.
} 
cumprimento da função social da cidade e propriedade, porém sem instrumentos adequados para alcançá-la.

Desta maneira, a cidade de Boa Vista permanecia sem um disciplinamento urbano. Os lotes urbanos continuavam sendo doados e a especulação já apresentava sinais fortes, principalmente nas áreas nobres - setor Leste e centro da cidade, e as ocupações irregulares persistiam nas áreas periféricas da cidade. Com isso, a cidade ia carecendo de equipamentos e serviços urbanos em sua totalidade.

Os processos espaciais, elementos mediadores entre processos sociais e organização do espaço, passam a constituir desta forma num conjunto de forças postas em ação por determinados atores que atuam ao longo do tempo, originando localizações, relocalizações e permanência de atividades e do homem sobre 0 espaço (CORRÊA, 1993), apresentando-se como expressão da acumulação capitalista e da forma como esta acumulação promoveu as mudanças que possibilitaram o desenvolvimento econômico e o acirramento das contradições sócioespaciais na cidade (NUNES, 2007, p. 20).

Percebe-se que o dualismo urbanização-cidade permanece como expressão de uma relação intrínseca e indissociável, mas agora caracterizado pelo rompimento da identidade entre processo e forma, no que se refere à tendência de concentração (SPOSITO, 2004, p. 10).

Até o ano de 1993, a cidade possuía 31 bairros; Centro, Mecejana, São Francisco, São Pedro, Canarinho, Aparecida, 31 de Março, São Vicente,Dos Estados, Novo Planalto, 13 de Setembro, Pricumão, Liberdade, Jardim Floresta, Marechal Rondon, Centenário, Cauamé, Buritis, Asa Branca, Caimbé, Caranã, Paraviana, Novo Canaã, Feliz Valois de Araújo, Jardim Equatorial, Jardim Tropical, Operário, Distrito Industrial, Calungá, Tancredo Neves e Caçari (BARROS, 1995, p. 152)

A expansão urbana continuava a crescer rumo ao setor Oeste da cidade, e os equipamentos e serviços permaneciam concentrados na área central da cidade, o que dificultava o acesso aos serviços por parte da população residente no referido setor em razão da distância entre o centro e a periferia e, em particular, pela situação precária do sistema de transporte. 
Nos períodos compreendidos entre os anos de 1993 a 1996, de 2001 a 2004 e de 2005 a 2008. As mudanças na paisagem urbano de Boa Vista foram visíveis. Nesse período o município estava sob a administração da prefeita Teresa Juca.

Já em sua primeira gestão de 1993 a 1996, a prefeitura ampliou o sistema viário em 80,4 quilômetros de ruas e avenidas pavimentadas [...], o que se tornou um programa permanente de melhoria do sistema viário. Para tanto implantou uma usina de asfalto e atuou na pavimentação das ruas e avenidas utilizando paralelepípedos [...]. Os recursos para execução das obras eram oriundos do Governo Federal, por meio de emendas ao orçamento federal e convênios (PMBV, 1993-1996, p. 9).

De acordo com a PMBV (1993-1996, p. 12-13)

\begin{abstract}
A pavimentação das ruas foi importante medida social, fortalecendo a cidadania dos moradores dos bairros carentes, antes abandonados, reduzindo os problemas de trafego nos invernos fortes e melhorando as condições sanitárias da população, com a eliminação de alargamentos permanentes [...] a prefeitura em apenas três anos pavimentou, com paralelepípedos, 49 ruas em 12 bairros diferentes, totalizando $12 \mathrm{~km}$ de ruas elou 110 mil metros quadrados [...] após a instalação da usina de asfalto, a prefeitura iniciou um amplo programa de pavimentação nos bairros carentes, mantendo o calçamento em paralelepípedos nas ruas secundarias (Quadro 03 e 04).
\end{abstract}

\begin{tabular}{|l|c|c|c|}
\hline \multicolumn{4}{|c|}{ Área pavimentada em paralelepípedos por bairro \Déc.90.Séc.XX } \\
\hline \multicolumn{1}{|c|}{ Bairro(s) } & № de ruas & Extensão & Área $\left(\mathrm{m}^{2}\right)$ \\
\hline Conjunto Cambará & 3 & 980 & 8.836 \\
\hline Tancredo Neves II & 5 & 2.470 & 24.000 \\
\hline Santa Teresa & 6 & 960 & 11.387 \\
\hline Jóquei Clube & 7 & 2.670 & 24.200 \\
\hline Pricumã & 7 & 531 & 9.911 \\
\hline Liberdade & 2 & 290 & 2.953 \\
\hline Mecejana & 6 & 830 & 6.362 \\
\hline 31 de Março & 4 & 920 & 5.850 \\
\hline Aparecida & 6 & 1.277 & 8.107 \\
\hline Caçari & 1 & 630 & 5.272 \\
\hline São Pedro & 1 & 122 & 976 \\
\hline Bairro dos Estados & 1 & 290 & 2.320 \\
\hline TOTAL & $\mathbf{4 9}$ & $\mathbf{1 1 . 9 7 0}$ & $\mathbf{1 1 0 . 1 7 4}$ \\
\hline
\end{tabular}

Quadro 03: Área pavimentada em paralelepípedos por bairro $\backslash$ Déc. 90

Fonte: Secretaria Municipal de Obras e Urbanismo \Déc. 90 


\begin{tabular}{|l|c|c|c|}
\hline \multicolumn{4}{|c|}{ Área pavimentada em paralelepípedos por bairro $\backslash$ Déc.90.Séc.XX } \\
\hline \multicolumn{1}{|c|}{ Bairro(s) } & No de ruas & Extensão & Área $\left(\mathbf{m}^{\mathbf{2}}\right)$ \\
\hline Conjunto Tiradentes & 4 & 3.730 & 26.110 \\
\hline Aparecida & 2 & 950 & 6.650 \\
\hline São Francisco & 8 & 4.030 & 19.310 \\
\hline Nova Canaã & 1 & 400 & 2.800 \\
\hline São Vicente & 4 & 540 & 3.140 \\
\hline Centro & 4 & 1.030 & 15.280 \\
\hline Santa Teresa & 7 & 3.700 & 25.900 \\
\hline Buritis & 2 & 1.520 & 10.880 \\
\hline TOTAL & $\mathbf{3 2}$ & $\mathbf{1 5 . 9 0 0}$ & $\mathbf{1 1 0 . 0 7 0}$ \\
\hline
\end{tabular}

Quadro 04: Área pavimentada em asfalto por bairro\ Déc. 90

Fonte: Secretaria Municipal de Obras e Urbanismo \Déc. 90

Entre as principais reformas e construções de equipamentos urbanos, a prefeitura realizou 28 obras de reforma, num total de 6.077,36 metros quadrados de área construída. No tocante a construções elou ampliações de edificações "a cidade de Boa Vista ganhou 18 novos prédios público elou ampliações, num total de 5.084,95 metros quadrados de área construída" (PMBV: 1993-1996, p. 25).

No ano de 1993 foi implantado o Complexo Poliesportivo Ayrton Senna, localizado em uma das principais avenidas da cidade - Êne Garcez (Figura 50; 51 e 52) -, com 75.000 metros de área urbanizada é considerado o maior projeto de urbanização em execução no Norte do País. Lembrando que a arquitetura (quiosque, bancos da praça entre outros) inicial do complexo foi de autoria da arquiteta urbanista Sandra Maria Pinheiro Veras.

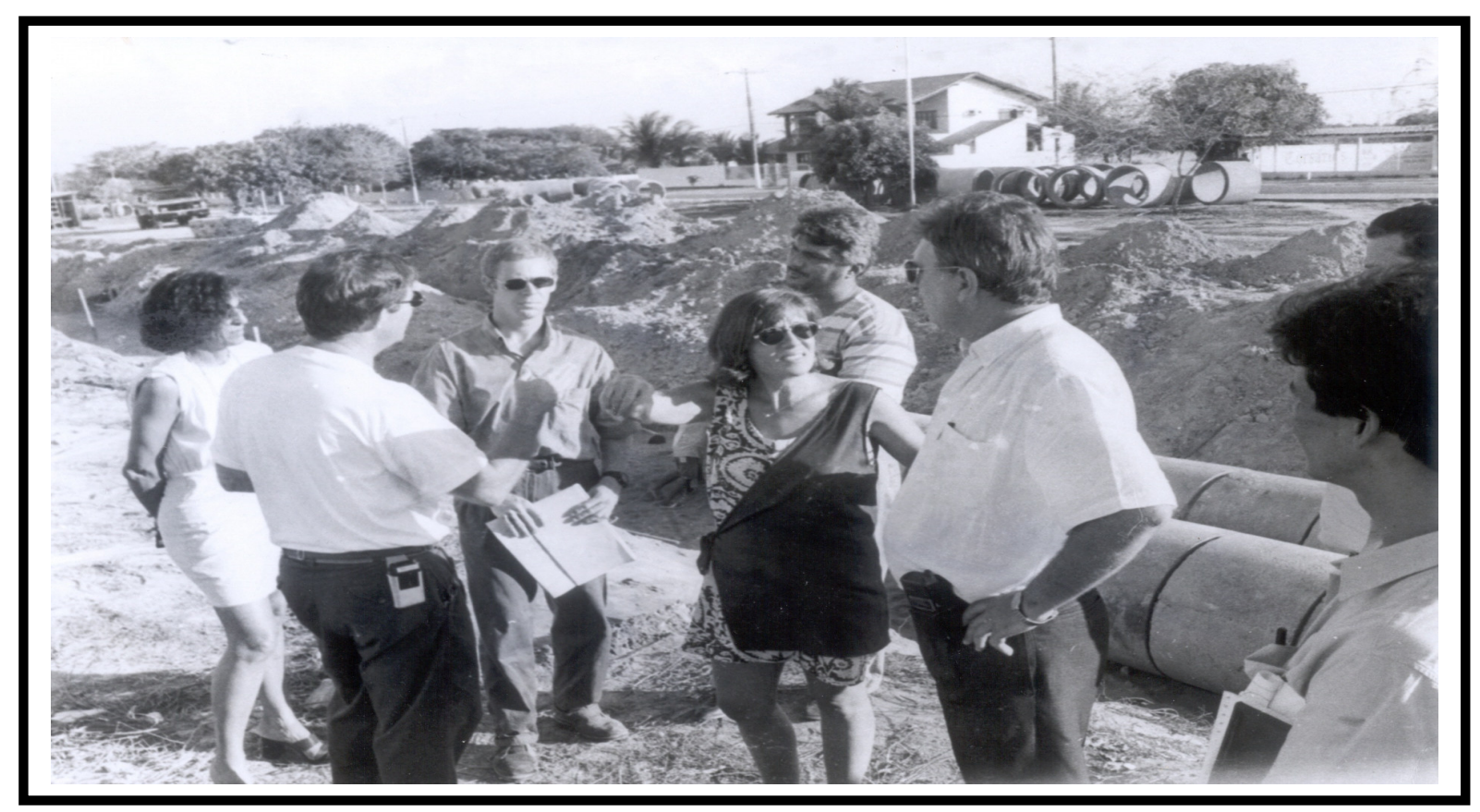

Figura 50: Inicio das Obras de Implantação do Complexo Poliesportivo Ayrton Senna \ Déc.90 Foto: Acervo de Tiago Orihuela 


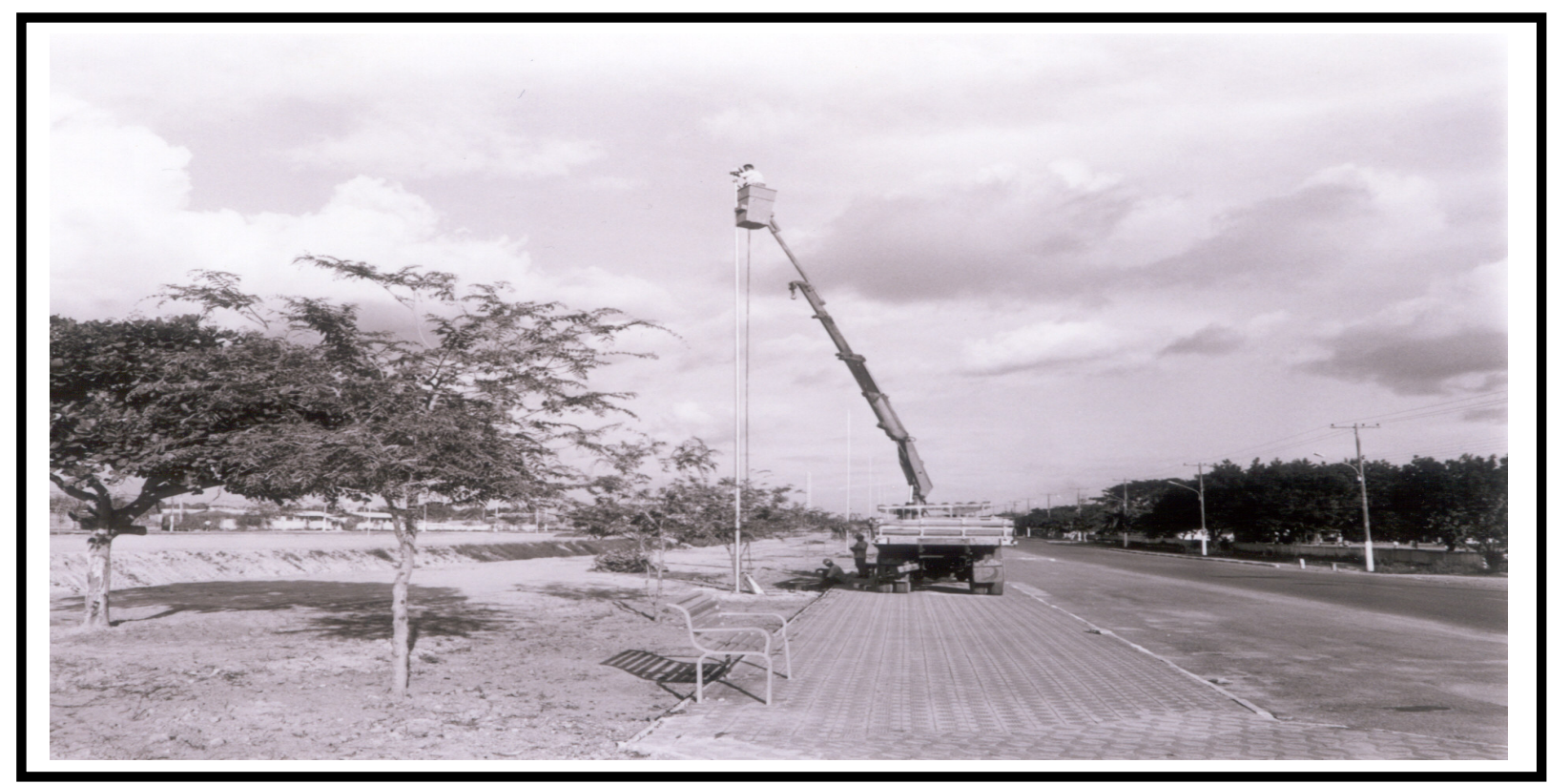

Figura 51: Inicio das Obras de Implantação do Complexo Poliesportivo Ayrton Senna \Déc.90 Foto: Acervo de Tiago Orihuela

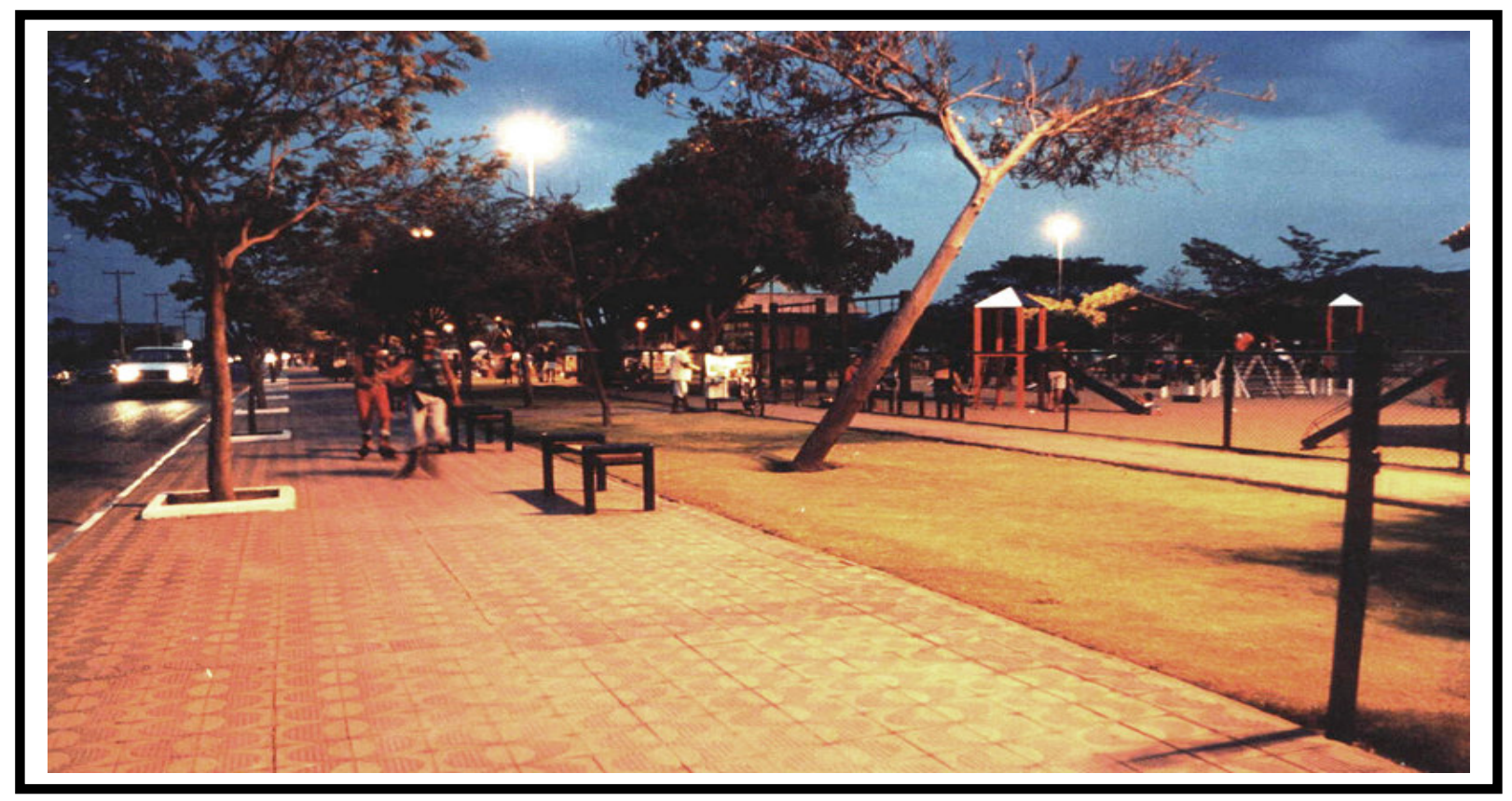

Figura 52: Complexo Poliesportivo Ayrton Senna $\backslash 2007$

Foto: Acervo de Tiago Orihuela 
No setor de drenagem e saneamento, a prefeitura fez um levantamento das áreas críticas da cidade, já que,por ser uma cidade plana, Boa Vista sofre muito durante as chuvas intensas, principalmente porque muitos bairros foram implantados sem qualquer obediência ao Plano Diretor de 1991. Com isso, entre os anos de 1993 e 1996, a Prefeitura executou o maior trabalho de drenagem e saneamento realizado na cidade (1993-1996, p. 36). Como mostra Quadro 05.

\begin{tabular}{|l|c|c|}
\hline \multicolumn{2}{|c|}{ Valas Tubuladas } \\
\hline \multicolumn{2}{|c|}{ Rua $\backslash$ Avenida } & Bairro \\
\hline Amajari & São Vicente & Extensão (m) \\
\hline Mestre Albano & Liberdade & 95 \\
\hline Nossa Senhora de Nazaré & Tancredo neves & 260 \\
\hline Edmundo Sales & Buritis & 1.070 \\
\hline Venezuela & Pricumã & 130 \\
\hline Nossa Senhora da Consolata & São Vicente & 144 \\
\hline Rua Palmeiras & Pricumã & 158 \\
\hline Ataíde Teive & Caimbé & 150 \\
\hline Brigadeiro Eduardo Gomes & 31 de Março & 72 \\
\hline Avenida E (Tiradentes) & Caranã & 465 \\
\hline Venezuela (Trevo) & Pricumã & 30 \\
\hline Bandeirantes & Buritis & 600 \\
\hline C-7 & Asa Branca & 260 \\
\hline Parima e Caroebe & Calungá & 80 \\
\hline Ataíde Teive & Asa Branca & 134 \\
\hline Mestre Albano & Asa Branca & 505 \\
\hline Imigrantes & Buritis & 592 \\
\hline TOTAL & & 684 \\
\hline
\end{tabular}

Quadro 05: Valas Tubuladas $\backslash$ Déc. 90

Fonte: Secretaria Municipal de Obras e Urbanismol1993-1996

Dando continuidade aos trabalhos de urbanização, a prefeitura implantou um sistema de iluminação em quase toda a cidade, em especial nas principais avenidas e praças, como mostra o Quadro 06 e 07 e a Figura 53. Os bairros mais afastados foram atendidos em esquema de rodízio, ou seja, precariamente. 


\begin{tabular}{|l|c|}
\hline \multicolumn{1}{|c|}{ Avenida } & Metros \\
\hline Ville Roy & 4.900 \\
\hline Mário Homem de Melo & 1.300 \\
\hline Manoel Felipe & 2.600 \\
\hline Ataíde Teive & 3.000 \\
\hline Capitão Júlio Bezerra & 2.300 \\
\hline Getúlio Vargas & 3.000 \\
\hline Major Williams & 1.600 \\
\hline Sebastião Diniz & 2.900 \\
\hline Nossa Senhora Consolata & 2.000 \\
\hline Santos Dumont & 2.200 \\
\hline Galycon de Paiva & 700 \\
\hline Castelo Branco & 1.000 \\
\hline Benjamin Constant & 3.000 \\
\hline TOTAL & 30.500 \\
\hline
\end{tabular}

Quadro 06: Avenidas iluminadas $\backslash$ Déc. 90

Fonte: Secretaria Municipal de Obras e Urbanismol1993-1996

\begin{tabular}{|l|c|}
\hline \multicolumn{1}{|c|}{ Praça(s) } & Bairro(s) \\
\hline Complexo Poliesportivo Ayrton Senna & Aeroporto \\
\hline Do Centro Cívico & Centro \\
\hline Da Bandeira & Centro \\
\hline Da Mecejana & Mecejana \\
\hline Asa Branca & Asa Branca \\
\hline Simon Bolívar & São Vicente \\
\hline Do Estudante & São Pedro \\
\hline Pricumã & Pricumã \\
\hline
\end{tabular}

Quadro 07: Praça com iluminação \ Déc. 90

Fonte: Secretaria Municipal de Obras e Urbanismol1993-1996 


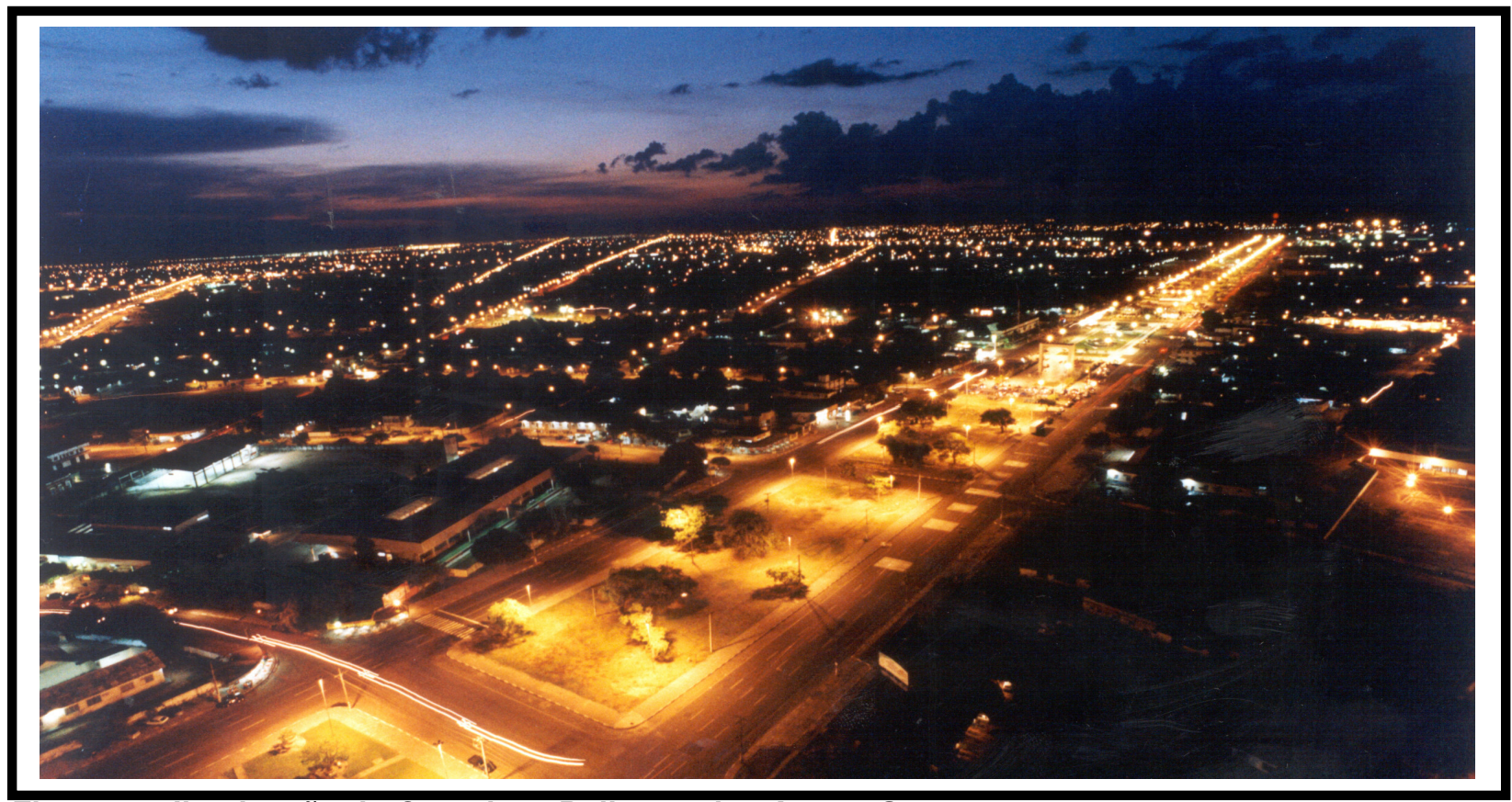

Figura 53: lluminação do Complexo Poliesportivo Ayrton Senna

Foto: Acervo de Orib Ziedson

No que tange à educação, a prefeitura ampliou as escolas municipais, localizadas nos bairros Aparecida, Pricumã e dos Estados, suprindo em parte a carência por escolas municipais na capital.

No setor de saúde, ampliou e reformou os postos de saúde com recursos provenientes do Sistema de Saúde - SUS, por meio de convênios com a Fundação Nacional de Saúde, com o Ministério da Saúde e por meio de emendas ao orçamento Geral da União. Além disso, criou programas de assistência a saúde da população, como o Programa de Assistência a Criança, ao Estudante, ao Adolescente, a Saúde da mulher, de Agente Comunitários de Saúde entre outros (PMBV,1993-1996, p. 63-96)

No que concerne ao meio de transporte, a ação da prefeitura não alcançou os objetivos propostos, permanecendo o sistema de transporte coletivo deficitário. A frota de ônibus continuou insuficiente (até hoje - grifo nosso), as linhas não atendiam toda a cidade e não havia abrigo de passageiros.

Para solucionar o problema, a prefeitura adotou as seguintes medidas:

- Criou um regulamento do transporte coletivo de Boa Vista, prevendo obrigações e deveres dos concessionários, dos passageiros e da fiscalização municipal; 
- Criou uma Diretoria de Transporte na Empresa Municipal de Urbanismo - EMHUR, especificamente para cuidar da administração do sistema de ônibus;

- Reformou o Terminal de Integração;

- Reestruturou o serviço de transporte com abertura de licitação para atendimento de novos roteiros de linha de coletivo;

- $\quad$ Sinalizou as paradas de ônibus; e

- Implantou abrigo de passageiros, modernos e com iluminação própria, à noite (PMBV, 1993-1996, p. 126) (Figura 54).

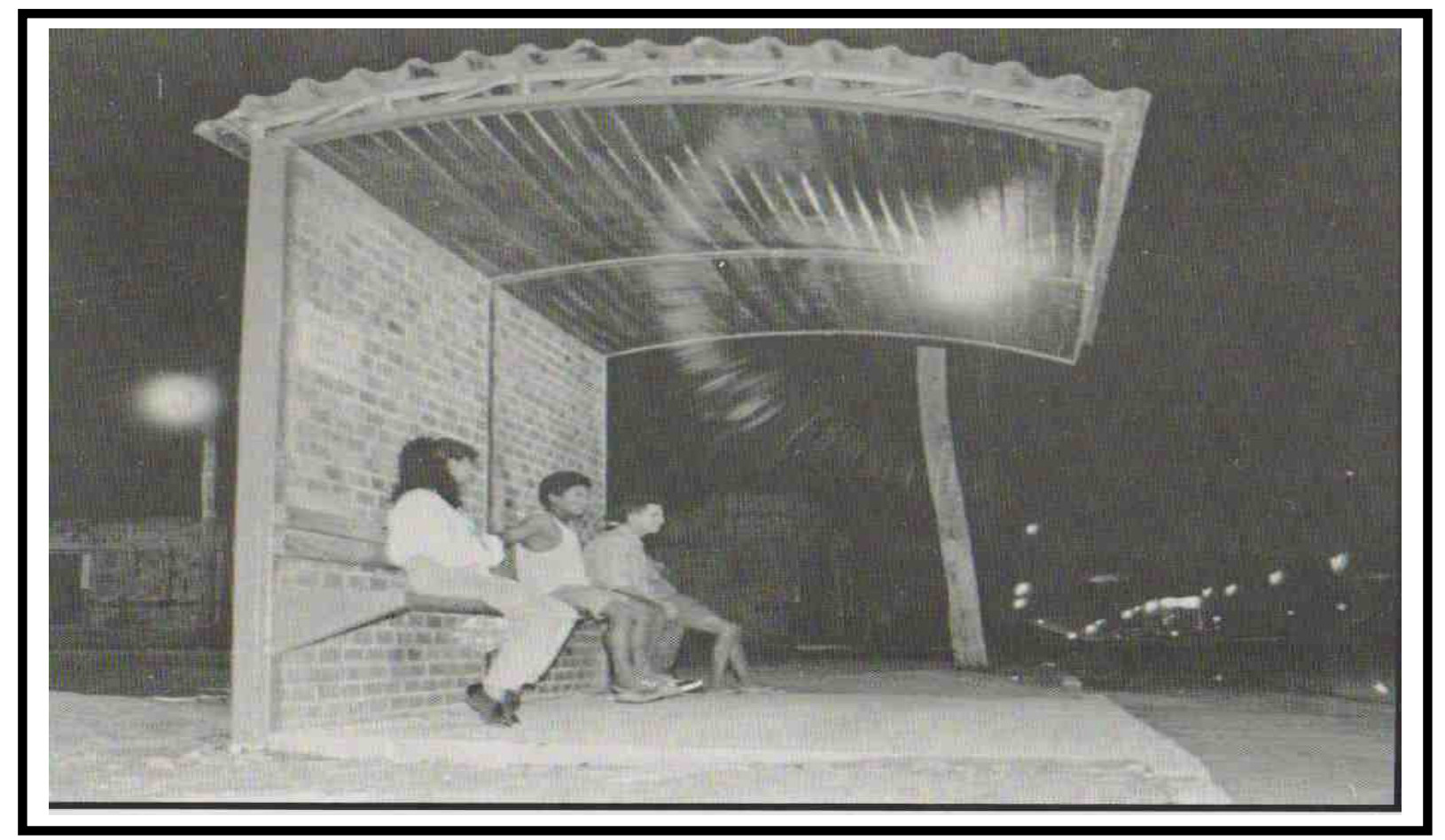

Figura 54: Abrigo de passageiros \Déc.90

Fonte: PMBV, 1993-1996

Desta maneira, somos levados a crê que as ações urbanísticas, supramencionadas, foram intervenções políticas sobre um sistema sócioespacial Boa Vista -, incorporadas ao espaço, por meio de um planejamento estratégico em que a estrutura das relações entre processo de produção e processo de consumo estava estritamente relacionada com a promoção do espaço urbano de Boa Vista. 
Por isso, o processo de expansão da cidade suscitou profundas mudanças no seu interior, isto é, modelou a sua estrutura. Sendo que o processo desta estruturação deu-se a partir da inserção de equipamentos e serviços que (re) produziu novas formas e novas funcionalidades no espaço intra-urbano da cidade.

Contudo as ações urbanísticas, em sua maioria, foram direcionadas para a área central e seu entorno, que abrangia e abrange, até hoje, a área de maior valor imobiliário. Como conseqüência, se verifica uma nova configuração espacial no espaço intra-urbano da cidade e uma acumulação de atividade e de população diferenciada no conjunto urbano.

Para Castells (1979, p. 182-186) essa concentração das atividades no centro pode estar relacionada a três fatores:

a) Ao processo de ocupação do sítio urbano da cidade ou em função de um esquema planejado de cidade em forma de radiais (vias) de comunicação, que desempenha uma função simultaneamente integradora e simbólica com o conjunto da cidade, cuja a imagem clássica, nesta perspectiva, é a praça da cidade medieval, dominada pela igreja e o poder político, lugar privilegiado onde, de maneira espontânea e hierarquizada, reúnem-se os cidadãos.

b) Ao papel do centro enquanto zona de intercâmbio e coordenação de atividades descentralizadas [...]. Um tipo de centro essencialmente funcional [...], que pode representar uma especialização do processo de divisão técnica e social do trabalho [...] ou uma especialização geográfica de certo tipo de unidade de consumo e de serviço.

c) Ao papel do centro como núcleo lúdico, concentração de lugares de diversão e de ócio, implantação espacial das "luzes da cidade" [...] da sublimação do ambiente urbano propriamente dito, por meio de várias opções de consumo.

Todavia, segundo Castells (1979:186)

\begin{abstract}
Nenhuma destas três categorias de centros, que contêm uma forte dose de expressividade concreta, existem em si, mas apenas como resultado de um processo social de organização do espaço urbano. $O$ que quer dizer que $o$ centro urbano, bem como a cidade, é primordialmente produto e, por conseguinte, expressão manifestada por meio das formas sociais em ações e da estrutura da sua dinâmica interna.
\end{abstract}

Portanto a inserção de equipamentos urbanos no espaço intra-urbano de Boa Vista, seja no centro ou não, não existe em si mesmo, mas como elementos que se relacionam no conjunto da cidade, cujas as diferentes frações do espaço urbano 
(formas) desempenham diferentes funções e definem o seu papel no conjunto da estrutura e no processo de produção da cidade.

Desta forma, os conflitos urbanos não podem reduzir-se aos problemas posto pela ausência de equipamentos e serviços na periferia da cidade. Mas, principalmente, deve levar em conta o crescente consumo coletivo e as tensões suscitadas pelas formas da luta de classe na dinâmica de produção da cidade.

Com o acréscimo de infra-estrutura, a cidade têm crescido acentuadamente, e gerando grandes problemas sociais, sobretudo, por conta da expansão territorial urbana que está sujeita às leis de mercado e aos interesses do capital incorporador (NUNES, 2007, p. 23).

Entendemos, que a produção do espaço urbano de Boa Vista pode constituirse em um processo seletivo de acessibilidade à cidade, acentuando a diferenciação do espaço urbano e contribuindo para precarização das condições de vida de parcelas significativas da população urbana. A ausência de programas de acesso a terra e à habitação para a população de baixa renda, e a inadequação das normas urbanísticas e de controles têm favorecido a ocupação de terras inadequadas, nas quais vivem populações sem direito à propriedade.

Outro agravante é a abertura de loteamentos de alto padrão na zona Leste e a construção de conjuntos habitacionais sob a legitimação do Estado (Figura $55 \mathrm{e}$ 56), que promove a expansão urbana da cidade e acentua a precariedade territorial das áreas urbanas de pouco interesse imobiliário, resultando no aprofundamento das desigualdades sócioespaciais urbanas e predominando, nestes lugares opacos da cidade, os padrões de exclusão social, fruto da produção desigual e contraditória do espaço urbano (NUNES, 2007). Com isso, a cidade se expande e passa a ter uma nova configuração espacial. 


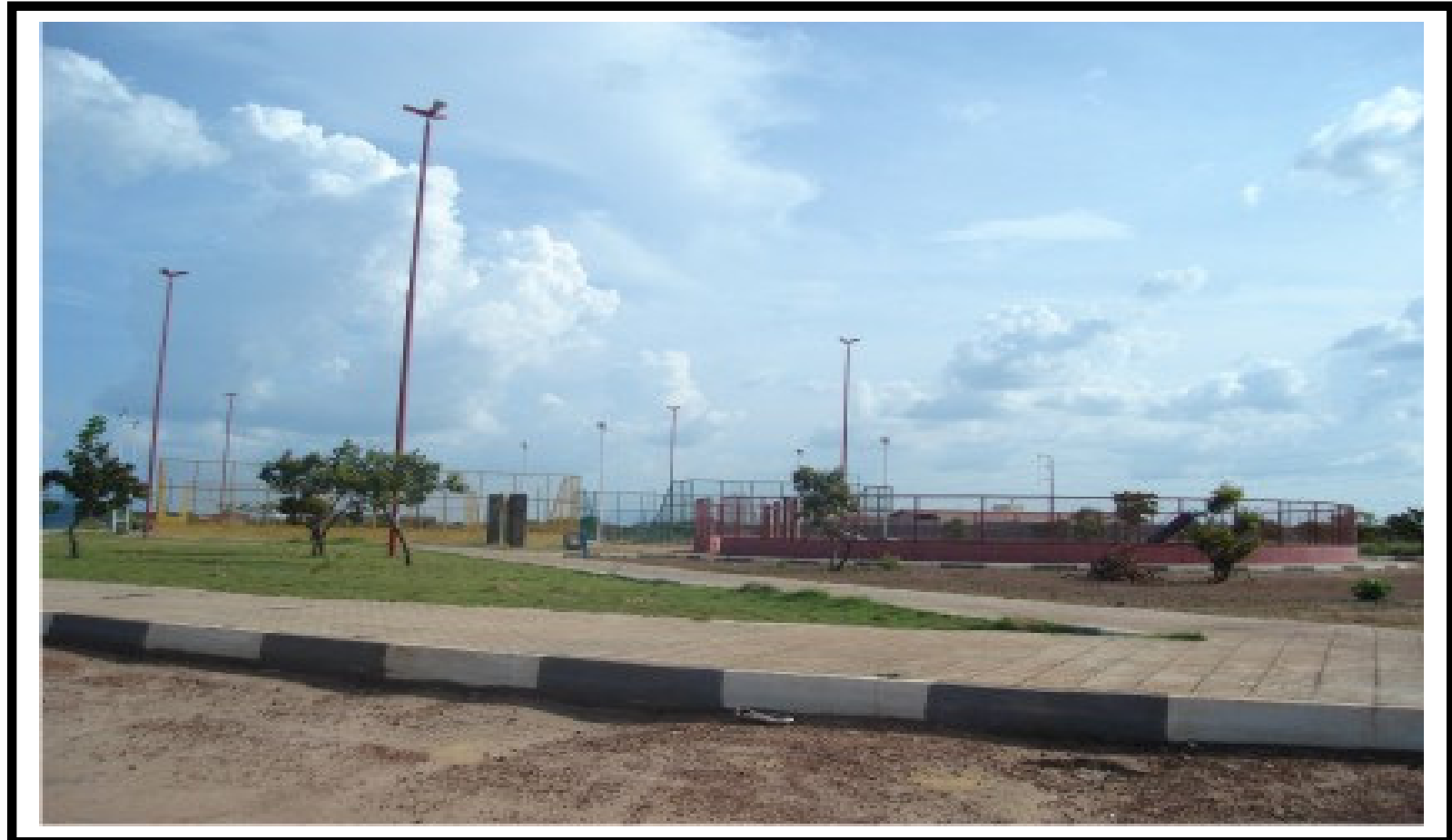

Figura 55: Residencial River Parque (Bairro Caçari - Zona Leste)

Foto: Acervo de João Theófilo R. Pereiral2008

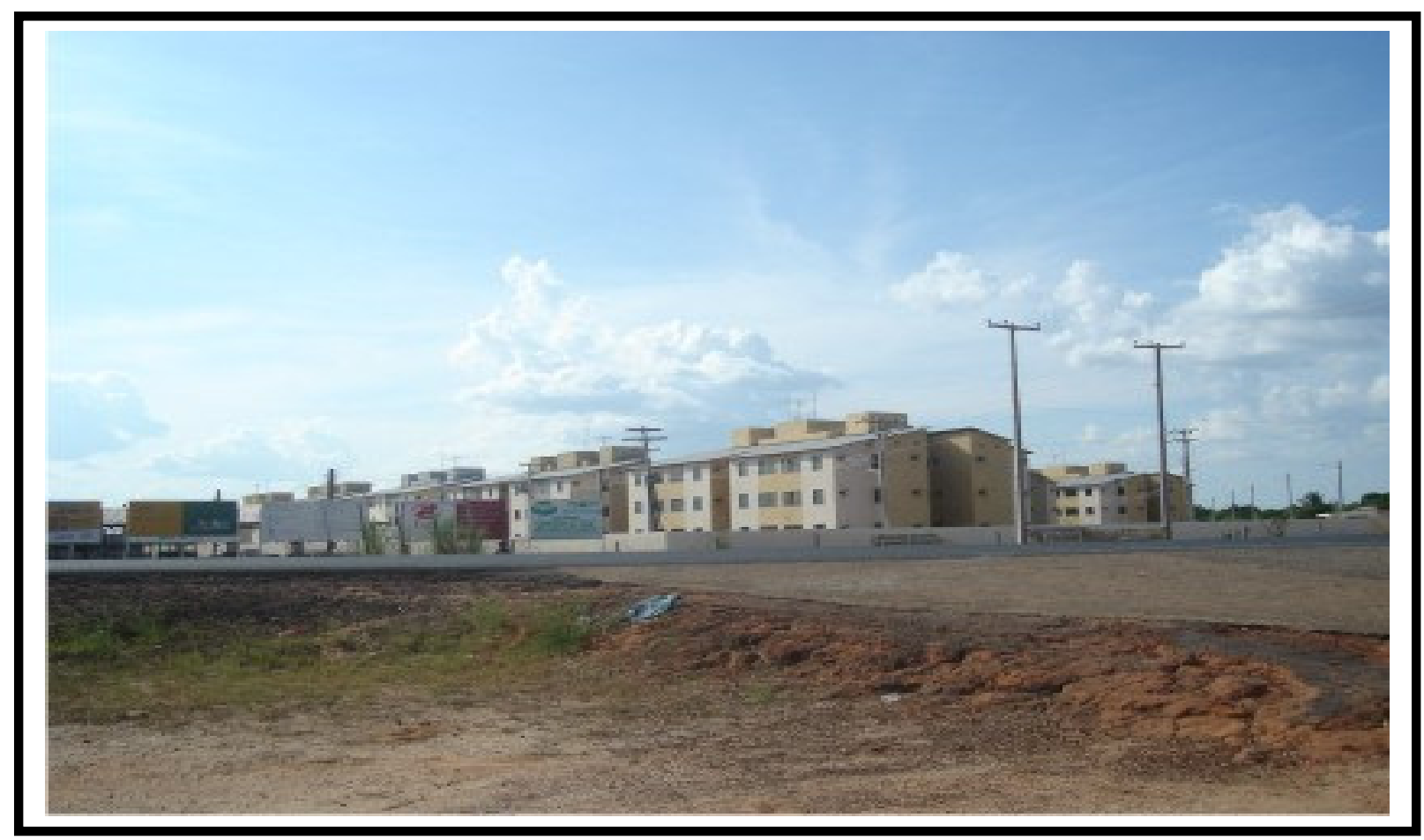

Figura 56: Conjunto do Servidor (Bairro Caranã- Zona Norte)

Foto: Acervo de João Theófilo R. Pereira 2008 
Cabe registrar que essa expansão da cidade também é decorrente de um rápido crescimento demográfica ocorrido num curto espaço de tempo. Para exemplificar, em 1950 havia apenas 17.247 habitantes em todo o município de Boa Vista, dos quais 5.133 concentravam-se na área urbana; no ano de 2000 esse total chegou a 230.759 habitantes, dos quais 205.852 localizavam-se dentro dos limites do perímetro urbano, o que representou um crescimento populacional significante no período (IBAM:2006).

Esse acréscimo populacional no ano de 2000 se deve em parte à política adotada por Ottomar de Souza Pinto, então prefeito, que, ao incentivar o setor agrícola e a migração, atraía muitas pessoas oriundas da região Nordeste e Centro - Sul para a cidade de Boa Vista com a promessa de casa própria e trabalho.

Seguindo a trama político-administrativa, nos anos de 2001 a 2004, inicia-se a segunda gestão da prefeita Teresa Jucá, que culmina com sua reeleição em 2005.

Sua atuação foi uma continuidade dos trabalhos da primeira administração que tinha como objetivo a promoção do espaço urbano de Boa Vista e sua ascensão no cenário político.

Deu ênfase ao setor de transporte por ser um serviço indispensável na dinâmica interna da cidade. Para tanto, construiu o Terminal de Integração do Caimbé, João Firmino Neto (hoje desativado) (Figura 57). Reformou por completo o mini-terminal rodoviário Luís Canuto Chaves, e deu início às obras de reformulação do novo terminal no centro. Essa ação, na concepção da prefeitura, tinha como propósito acompanhar o crescimento dos bairros, uma vez que a cidade vinha crescendo rapidamente e o setor de transporte não atendia a demanda da população (REVISTA É AGORA, 2006, p. 14-15). 


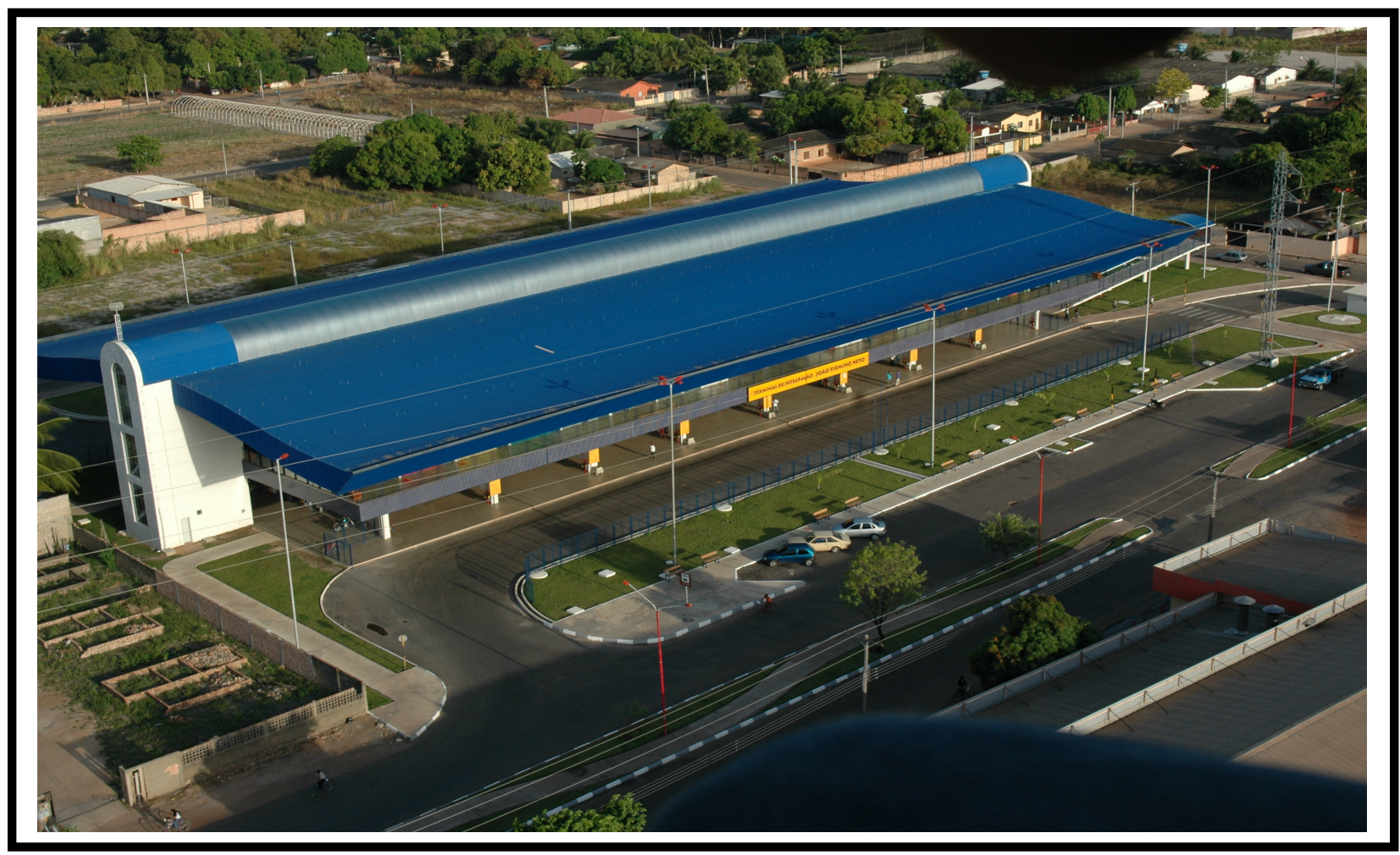

Figura 57: Terminal de Integração do Caimbé \João Firmino Neto - 2006

Foto: Acervo de Tiago Orihuela

Também padronizou o sistema de transporte Táxi - Lotação ${ }^{26}$. Esse sistema de transporte "coletivo" possui rota para todos os bairros da cidade. Sendo uma alternativa de circulação imprescindível. Pois, além de gerar renda e emprego, supre em parte a deficiência do transporte coletivo na cidade.

No aspecto bem estar e lazer da população residente nos bairros distante do "centro", a prefeitura construiu a Vila Olímpica no bairro Olímpico, que levou lazer e esporte aos moradores de bairros como Senador Hélio Campos, Cambará, Nova Cidade, Pintolândia e Asa Branca. A Vila Olímpica é a segunda maior do gênero na Região Norte e conta com infra-estrutura completa: pista de atletismo oficial, quadras poliesportivas, campo de futebol e um ginásio para 6.500 pessoas sentadas (Figura 58) [...]. Também construiu o Parque Germano Augusto Sampaio, na Pintolândia, com 177 mil m² de área de lazer, esporte e entretenimento (Figura 59) (REVISTA É AGORA, 2006, p. 16).

\footnotetext{
${ }^{26}$ Sistema de transporte coletivo existente em Boa Vista em que o taxi particular, ou lotação como é chamado, realiza as rotas de transporte de passageiros em todos os bairros da cidade e cobra o mesmo valor da passagem de ônibus. Esse sistema de transporte é regulamentado pela Empresa Municipal de Desenvolvimento Urbano e Habitação de Boa Vista - EMHUR.
} 


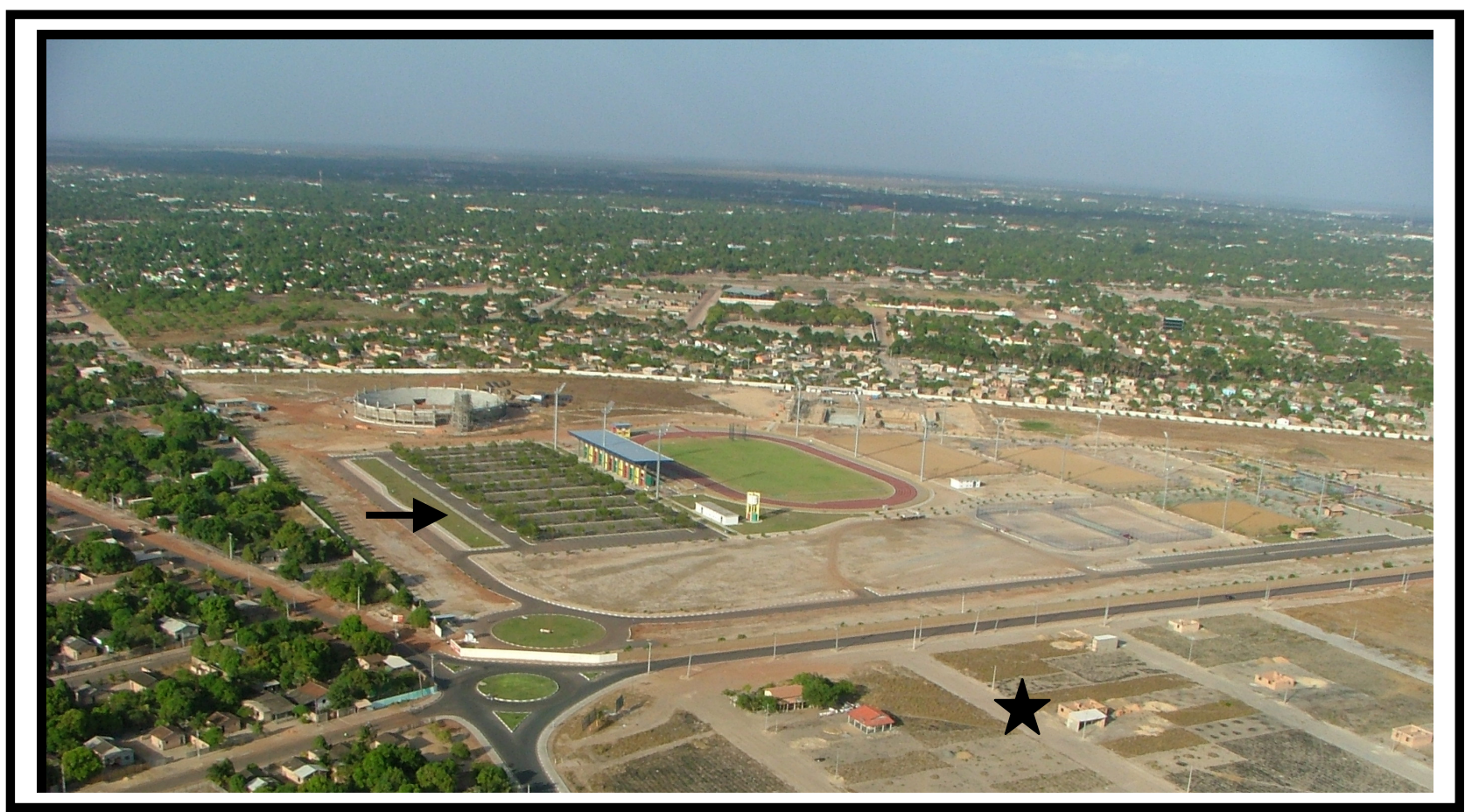

Figura 58: Vista aérea da Vila Olímpica $\backslash 2007$ (Ao lado um loteamento imobiliário) (Zona Oeste) Legenda: \Vila Olímpica $\backslash$ Loteamento imobiliário Foto Acervo de Roberto Caleffi IUFRR

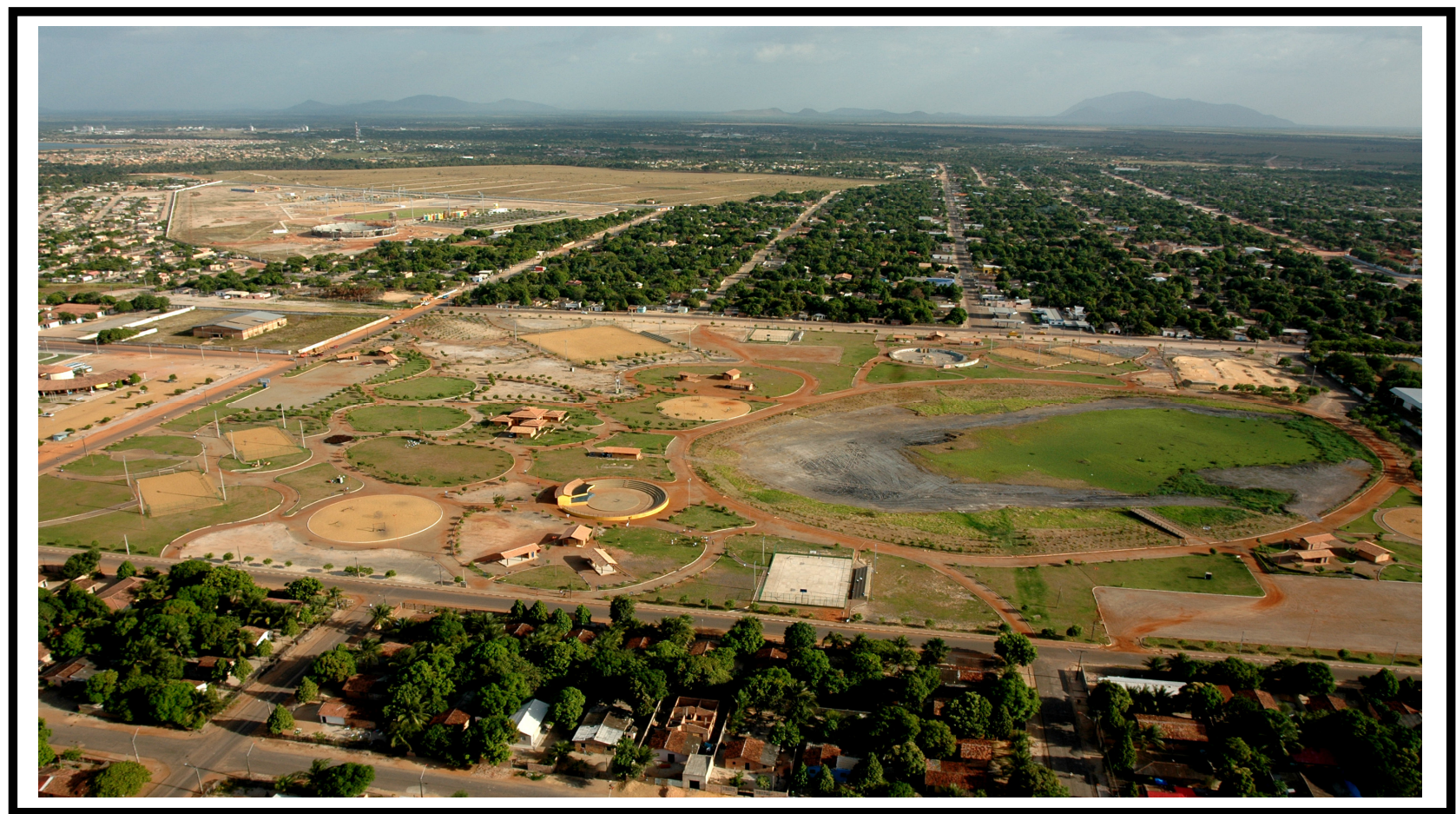

Figura 59: Vista aérea do Parque Germano Augusto Sampaio (Zona Oeste) Foto: Acervo de Tiago Orihuela 
Com base no exposto, somos chamados a dialogar com Villaça (1998, p. 13) ao afirmar que "o simples registro de transformações espaciais não é suficiente para caracterizar a estruturação ou a reestruturação [do espaço]". Ou seja, não basta identificar as transformações físicas que ocorrem nas principais aglomerações urbanas brasileiras para denominá-la de reestruturação do espaço urbano, tratandoas como evidências das mudanças no modo de produção capitalista. Também é necessário verificar mudanças estruturais na vida social que justificam a mudança na lógica de consumo do espaço.

Essa afirmação de Villaça nos remete a uma realidade já existente no espaço urbano de Boa Vista, isto é, com a construção da Vila Olímpica e do Parque Germano Augusto Sampaio, os imóveis localizados nas proximidades desses equipamentos urbanos sofreram um acréscimo nos preços e, ao mesmo tempo, a especulação imobiliária (re) definiu novas áreas de ocupação, passando a ser, como diz Milton Santos, espaços luminosos.

Desta maneira, "é na expansão da cidade e do urbano que se desenvolve a acumulação capitalista, sendo que a cidade e o urbano passam a representar a expressão espacial desse sistema de produção" (CARLOS, 1994 apud NUNES, 2007, p. 22).

$\mathrm{Na}$ área central, esse processo não foi diferente, um exemplo foi a construção da Orla Taumanam (Figura 60) às margens do rio Branco, o Centro de Turismo, Artesanato e Geração de Renda Velia Coutinho e a Praça das Artes no Complexo Poliesportivo Ayrton Senna. Além de ser um espaço seletivo, em que os freqüentadores são da classe média e alta, o preço dos imóveis triplicou de valor. 


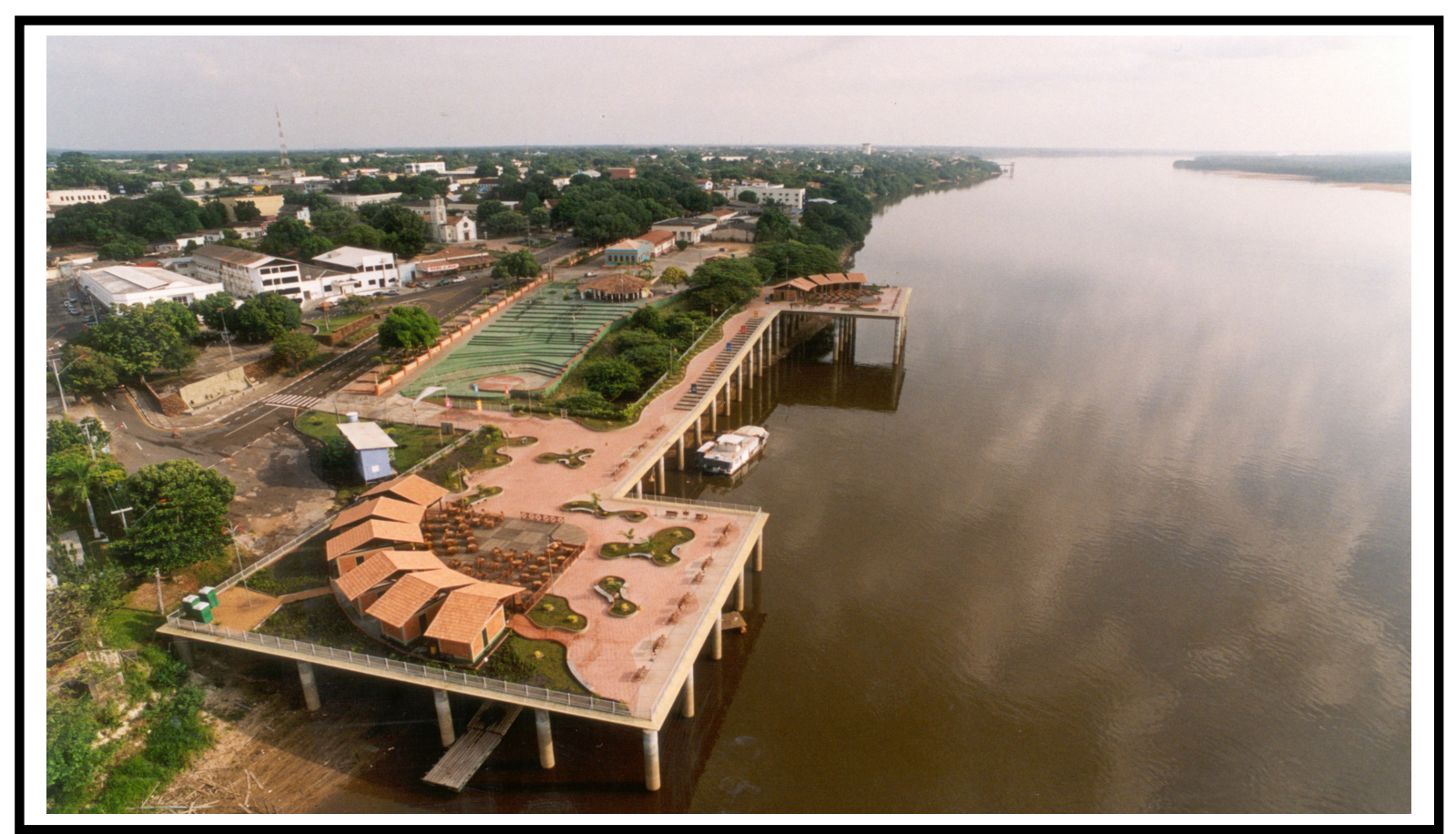

Figura 60: Vista aérea da Orla Taunamam $\backslash 2007$

Foto: Acervo de Tiago Orihuela

Vale ressaltar, em particular, e dada a sua importância como uma das principais áreas de entretenimento da cidade, que durante a construção da Orla ocorreram diversos "conflitos" de opiniões entre a população e o poder público por conta da área ser uma Área de Proteção Permanente - APP, isto é, imprópria para a construção. Porém o que se viu foi prevalecer à força do poder público e o interesse de uma pequena parcela da população.

Outro agravante é que essa ação da prefeitura de produzir espaços de entretenimento não atendeu a uma totalidade sócioespacial da cidade, uma vez que só veio a beneficiar uma parcela da população de maior poder aquisitivo, bem como a parcela mínima de empresários influentes, que foram contemplados com os pontos comerciais localizados na orla. Segregando, desta forma, o uso e ocupação desse patrimônio "público" pela maioria da população da cidade que é da classe média baixa.

Já em 2005, a prefeitura iniciou um intenso programa de urbanização no bairro Centenário, com a construção de 273 casas, 50 banheiros, 200 fossas sépticas, reforma de 40 moradia, duplicação e asfaltamento, construindo rotatórias de segurança, $4.160 \mathrm{~m}$ de calçadas e sarjeta. (REVISTA É AGORA, 2006, p. 18). 
Em seguida, deu continuidade ao trabalho de asfaltamento e calçada, executando $285 \mathrm{Km}$ de asfalto em 639 ruas e avenidas da capital e 117 de calçadas em vários bairros, como mostra o Quadro 8, abaixo:

\begin{tabular}{|l|c|c|c|c|c|}
\hline \multicolumn{1}{|c|}{ Bairro } & AsfaltolKm & Calçada $\mathbf{k m}$ & Bairro & Asfalto\Km & Calçada $\backslash \mathbf{K m ~}$ \\
\hline 13 de Setembro & 6 & - & Jardim Caranã & 15 & - \\
\hline 31 de Março & - & $440 \mathrm{~m}$ & Jardim Floresta & 38 & 6,020 \\
\hline Aeroporto & 16 & 2,120 & Jardim Primavera & 32 & $130 \mathrm{~m}$ \\
\hline Alvorada & 16 & 2,950 & Jardim Tropical & - & 1,620 \\
\hline Aparecida & 6 & $415 \mathrm{~m}$ & Jóquei Clube & 20 & - \\
\hline Asa Branca & 1 & - & Liberdade & 1 & 4,200 \\
\hline Bela Vista & 19 & - & Mecejana & 11 & 8,405 \\
\hline Dos Estados & - & 1,265 & Nova Canaã & 11 & 1,460 \\
\hline Buritis & 11 & 5,550 & Nova Cidade & 11 & - \\
\hline Caçari & 13 & - & Operário & $2.420 \mathrm{~m}$ & - \\
\hline Caetano Filho & 2 & - & Paraviana & 31 & - \\
\hline Caimbé & 13 & 4,800 & Pintolândia & 27 & 3,950 \\
\hline Calungá & 6 & 3,220 & Piscicultura & 12 & $800 \mathrm{~m}$ \\
\hline Cambará & 6 & 815 & Pricumão & 1 & 2,280 \\
\hline Canarinho & 1 & - & Raiar do Sol & 15 & 9,280 \\
\hline Caranã & 24 & 8,120 & Santa Luzia & 5 & 2,720 \\
\hline Cauamé & 38 & - & Santa Teresa & 26 & 2,730 \\
\hline Centenário & 17 & - & São Francisco & 1 & 1,890 \\
\hline Centro & - & 4,775 & São Vicente & 9 & 4,450 \\
\hline Cidade Satélite & - & $450 \mathrm{~m}$ & Sen. Hélio Campos & 17 & $960 \mathrm{~m}$ \\
\hline Cinturão Verde & 33 & - & Tancredo Neves & 10 & 6,570 \\
\hline Dr. Silvio Botelho & 3 & 9,790 & Cidade Satélite & 1 & - \\
\hline Dr. Silvio leite & 21 & - & União & 17 & $900 \mathrm{~m}$ \\
\hline Equatorial & 6 & 4,460 & & - & - \\
\hline Quadro 8: Astalto Calçada & & & & \\
\hline
\end{tabular}

\section{Quadro 8: Asfalto e Calçada}

Fonte: Revista é agora, 2006.

Nessa proposta de urbanização e geração de renda e emprego, a prefeitura desativou a lixeira pública e inaugurou o aterro sanitário, incentivando as famílias que sobreviviam em condições subumanas no lixão a criarem uma cooperativa [...]. Instalou, ainda, o Centro Comercial Caxambu para abrigar os camelôs que se espalhavam pelo centro da cidade. Hoje eles trabalham nas 142 lojinhas ( REVISTA BOA VISTA-23, 2004, p. 4) (Figura 61). 


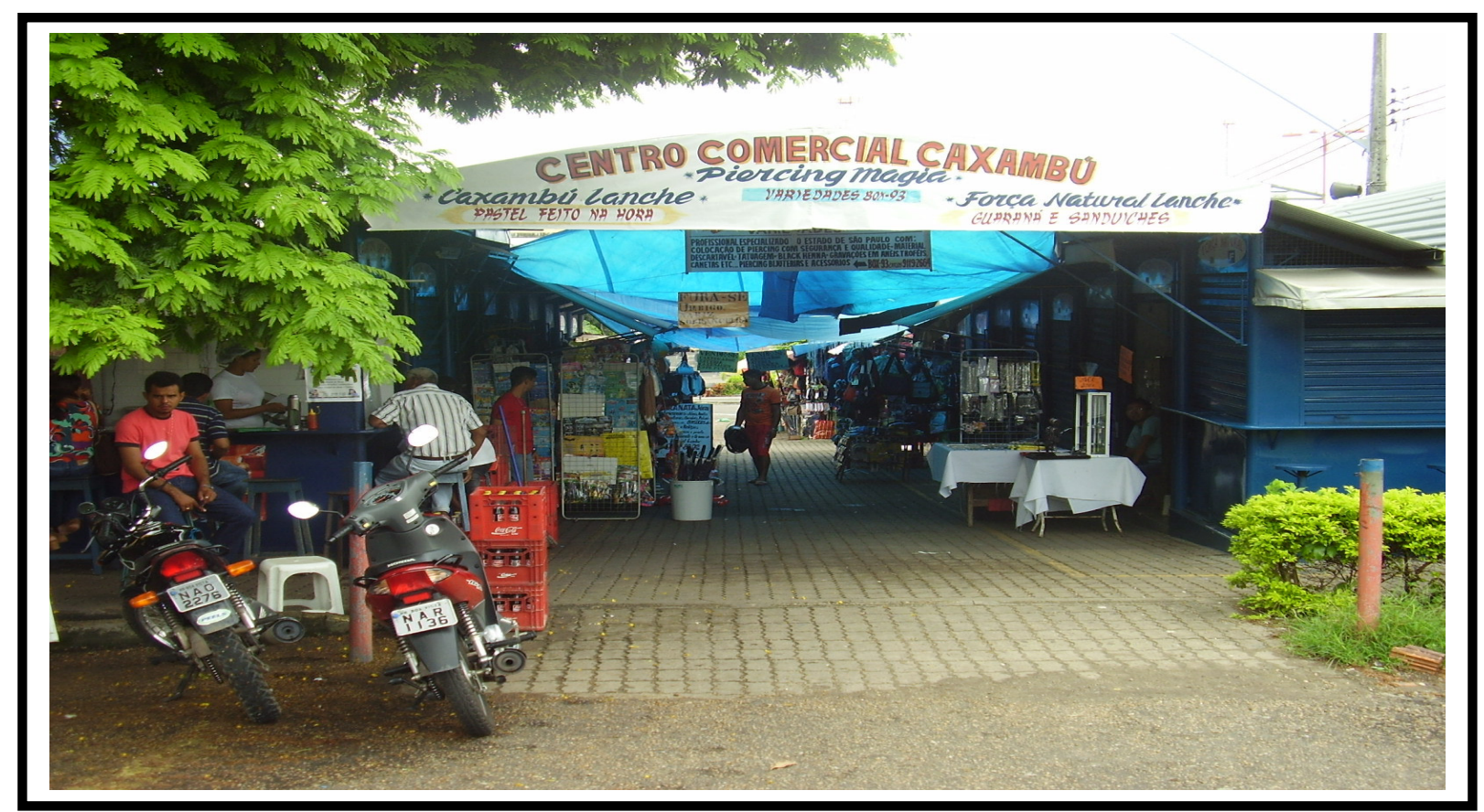

Figura 61: Centro Comercial Caxambu

Fonte: Acervo de Laura Patrícia Lopes Veras $\$ 2008$

Ainda com o apoio do Governo Federal e recursos próprios, a prefeitura deu continuidade aos programas sociais e implantou outros, como mostra o Quadro 9.

\begin{tabular}{|c|c|}
\hline Programa & Programa \\
\hline Sentinela & PETI \\
\hline $\begin{array}{l}\text { Núcleo de Assistência ao Dependente } \\
\text { Químico }\end{array}$ & Agente Jovem \\
\hline Estagiário Júnior & Guarda - Mirim \\
\hline Construindo o Futuro & Meninos do Dedo Verde \\
\hline Orquestra de Violões & Orquestra Sinfônica \\
\hline $\begin{array}{l}\text { Cernutri (Centro de Recuperação } \\
\text { Nutricional) }\end{array}$ & Projeto Crescer \\
\hline Corais & Coral ArtCanto \\
\hline \multirow[t]{2}{*}{ Bolsa - Alimentação } & Banda Juvenil \\
\hline & Bolsa - Escola \\
\hline
\end{tabular}

Quadro 9: Programas Sociais

Fonte: Revista Boa Vista 23/2004. 
No setor habitacional, a prefeitura entregou 1.172 casas dentro do projeto Morar Legal [...]. No caso, não optou em criar novos conjuntos habitacionais, que demandaria recursos maiores, e sim construir novas casas em diferentes bairros, aproveitando os lotes em locais com a infra-estrutura já existente, como asfalto, escola e posto de saúde (JORNAL DA PREFEITURA, 2006, p. 10).

Outro ponto a ser destacado é que o Governo do Estado, financiado pela Companhia de Desenvolvimento de Roraima CODESAIMA, construiu, na década de 90 do século XX e mais recentemente nos anos 2007 e 2008 financiado pela Caixa Econômica Federal, novos conjuntos nos bairros periféricos da cidade, como no bairro Bela Vista, Operário, Jóquei Clube, Jardim tropical, Olímpico, Pintolândia, Silvio Botelho, Santa Luzia e Senador Hélio Campos, Dr. Silvio Leite, Alvorada, Equatorial, Cidade Satélite e Caranã.

Conseqüentemente, as alterações na forma espacial e nos processos sociais da cidade alteraram a renda dos indivíduos e produziram novos territórios precários. Uma vez que esses programas habitacionais não beneficiaram todas as famílias carentes. Em particular, os do Governo do Estado, em sua maioria, são voltados exclusivamente para funcionários públicos estaduais de médio e baixo escalão.

\subsection{Plano Diretor estratégico de Boa Vista}

No ano de 2006, em cumprimento a Lei Federal 10.257 de 10 de julho de 2001, que regulamenta a política urbana nacional, expressa nos artigos 182 e 183 da Constituição Federal, a Prefeitura Municipal de Boa Vista dá início à reformulação do Plano Diretor da Cidade, que tem como principal objetivo garantir o direito de todos à cidade, ou seja, às riquezas naturais, aos serviços, à infra-estrutura e à qualidade de vida.

A nova lei corresponde ao conjunto de leis básicas de uso e ocupação do solo, que orientam e regulam a ação dos agentes sociais e econômicos sobre o território de todo o município, é o instrumento básico da política de desenvolvimento e expansão urbana.

Em linhas gerais, estabelece uma nova forma de apropriação do espaço urbano, baseada na função social da propriedade, na qual as propriedades precisam abrigar atividades ou construções que representem benefícios para toda a cidade. 
Esta formulação a respeito da apropriação do espaço alia-se, no dizer de Vicentini (2004, p. 20), às propostas de construção da análise de cidades ${ }^{27}$ expostas por Bresciani, que indicam a importância da formação das identidades sociais nos novos espaços urbanos, salientando como a introdução de modos de vida e de novos parâmetros de urbanidade permearam os espaços sociais definidos, promovendo novos usos e novas formas de apropriação; diferenciando o espaço público, na reelaboração da própria esfera pública, em oposição à esfera privada da vida, entendida pela noção de intimidade.

Para a elaboração do Diagnóstico Integrado, Plano Estratégico de Ação Municipal, Revisão e Adequação do Plano Diretor Urbano e Legislação de Regulamentação, a Prefeitura Municipal de Boa Vista contratou o Instituto Brasileiro de Administração Municipal - IBAM, com sede no Rio de Janeiro.

Conforme o relatório de análise da situação habitacional de Boa Vista elaborado pelo IBAM (2006, p. 1-32), os recursos para a elaboração do plano foram provenientes de contrato de empréstimo firmado entre a Prefeitura Municipal de Boa Vista e a Caixa Econômica Federal, no âmbito do Programa Nacional de Apoio à Gestão Administrativa e Fiscal dos Municípios Brasileiros - PNAFM, financiado pelo Contrato de Empréstimo Banco Interamericano de Desenvolvimento - BID11994/OC-BR, com o Governo Federal.

No processo de revisão e elaboração do novo Plano Diretor de Boa Vista PDBV, foi traçado um plano estratégico com ênfase na sustentabilidade ambientalurbana com a participação ${ }^{28}$ da população em conjunto com a prefeitura, objetivando realizar uma leitura sócioespacial da cidade e propor soluções coerentes para cada fração da cidade.

$\mathrm{Na}$ análise do Fórum Popular de Roraima em Defesa da Cidade - FPRDC, o que se viu foi apenas o plano estratégico e a concepção ambiental [...]. Já o processo participativo ficou a desejar, pois não atendeu as expectativas da população [...]. Segundo o FPRDC, o Gestor responsável pela coordenação do processo de elaboração do Plano Diretor só tinha representantes da prefeitura e dos

\footnotetext{
${ }^{27}$ BRESCIANI, M.S. Permanência e ruptura no estudo das cidades. In: FILGUEIRAS GOMES, M. A.; FERNANDES A. (Org.) Cidades \& História: Modernização das cidades brasileiras nos séculos XIX e XX. Salvados, 1992. Dissertação (Mestrado em Arquitetura e Urbanismo) - ANPUR, Universidade Federal da Bahia.

${ }^{28}$ São princípios metodológicos de elaboração do Plano Diretor: (I) Participação da prefeitura em todas as etapas do processo (II) Participação da população como contribuição efetiva nas definições do Plano Diretor (III) a incorporação da visão estratégica e ambiental no Plano Diretor (IV) tratamento temático das informações (IBAM, 2006).
} 
empresários, não contemplando a participação de representantes de sindicatos, associações de moradores, entidades profissionais entre outros (COHRE, 2005-2006, p. 78).

No entanto, para o COHRE (2005-2006, p. 79) apesar das observações feitas pelo FPRDC, o IBAM e a prefeitura utilizaram a seguinte metodologia de trabalho para elaborar o novo Plano Diretor:

- Leitura técnica da cidade contemplando o meio físico, biótico, social e econômico;

- Caracterização urbana, priorizando os temas da habitação, saneamento, mobilidade e transporte; e

- A leitura popularlcomunitária, que contemplou a realização de seminários de apresentação da leitura técnica, oficinas temáticas, audiências públicas.

Com base nos dados coletados, o IBAM incorporou ao Plano Diretor propostas para amenizar os problemas urbanos. Entre elas, a promoção do desenvolvimento econômico sustentável, a qualificação ambiental do município que tinha como objetivo promover "a proteção e valorização do ambiente natural", o ordenamento territorial, a estruturação urbana e a regularização fundiária e urbanística (COHRE, 2005-2006).

No caso do ordenamento territorial e da estruturação urbana, a proposta foi controlar o crescimento a sudoeste da cidade - onde estão as lagoas e as principais Áreas de Preservação Permanentes - APP's. Assim, os vetores de crescimento da cidade deverão ser induzidos rumo ao município de Alto Alegre (Oeste) (Figura 62) e a Norte, em direção à Venezuela (COHRE, 2005-2006). 


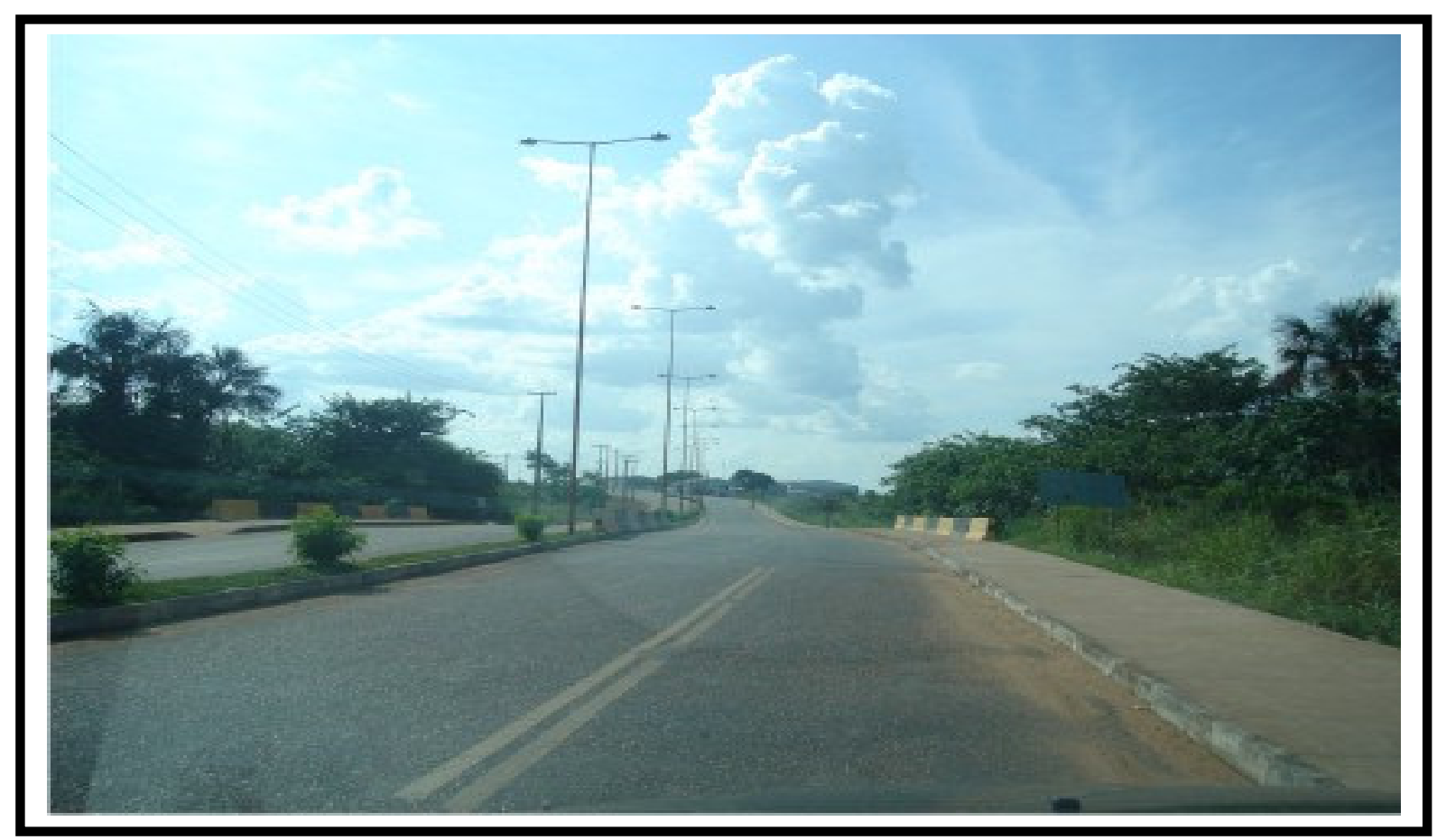

Figura 62: Zona Oeste de Boa Vista sentido ao Município de Alto Alegre

Foto: Acervo de João Theófilo R. Pereira $\backslash 2008$

Um fato importante a considerar é que esses espaços propostos para o crescimento da cidade carecem de estudos científicos sobre o grau de impacto sócio ambiental que possa advir de um assentamento dirigido pelo município ou por especuladores imobiliários. Uma vez, que envolve áreas pertencentes a particulares, a empresários, a políticos e, em muitos casos, ambientalmente frágeis.

Todavia o que se observa é uma ausência, um descaso elou uma conivência do poder municipal frente às freqüentes ocupações irregulares que vêm se processando nessas áreas (Figura 63). Situação que contribui diretamente para o desordenamento da cidade e ao mesmo tempo para a "indústria do sem teto". 


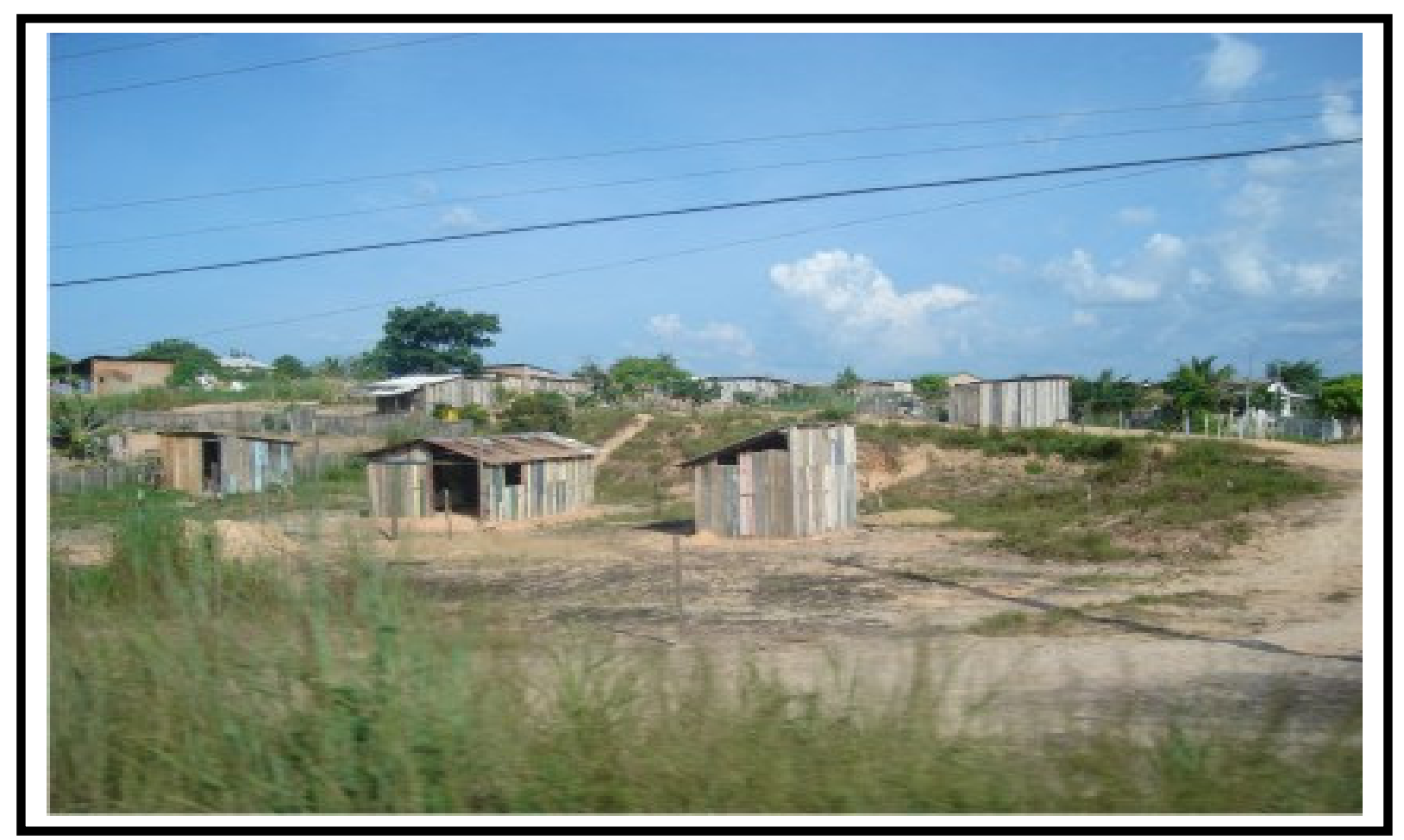

Figura 63: Ocupação Irregular - Monte das Oliveiras \Zona Norte: Bairro Aeroporto \(próximo ao rio Caumé - sentido Venezuela)

Foto: Acervo de João Theófilo R. Pereira $\backslash 2008$

Informações obtidas a partir de dados empíricos confirmam o que o IBAM já tinha afirmado em 2006 sobre a estrutura urbana de Boa Vista, isto é, que a estrutura urbana se encontra num elevado índice de segregação espacial em decorrência da expansão impulsionada pela implantação de conjuntos habitacionais e loteamentos que induziram os vetores de expansão para áreas ambientalmente frágeis e, portanto, inadequadas para a ocupação.

Ainda pior de tudo é a falta de rigor na aplicação das leis por parte do poder público, que é conivente com as inadequações no processo de ocupação de áreas frágeis ambientalmente. Como exemplo, citamos as ações para provisão de moradia para a população de "baixa renda" promovido pelo Governo Estado, denominado loteamento "Conjunto Cidadão" (Figura 64) e as residências de alto padrão de luxo situadas as margens do rio Branco (Figura 65). Ambas as construções foram feitas em Área de Proteção Permanentes - APP's. 


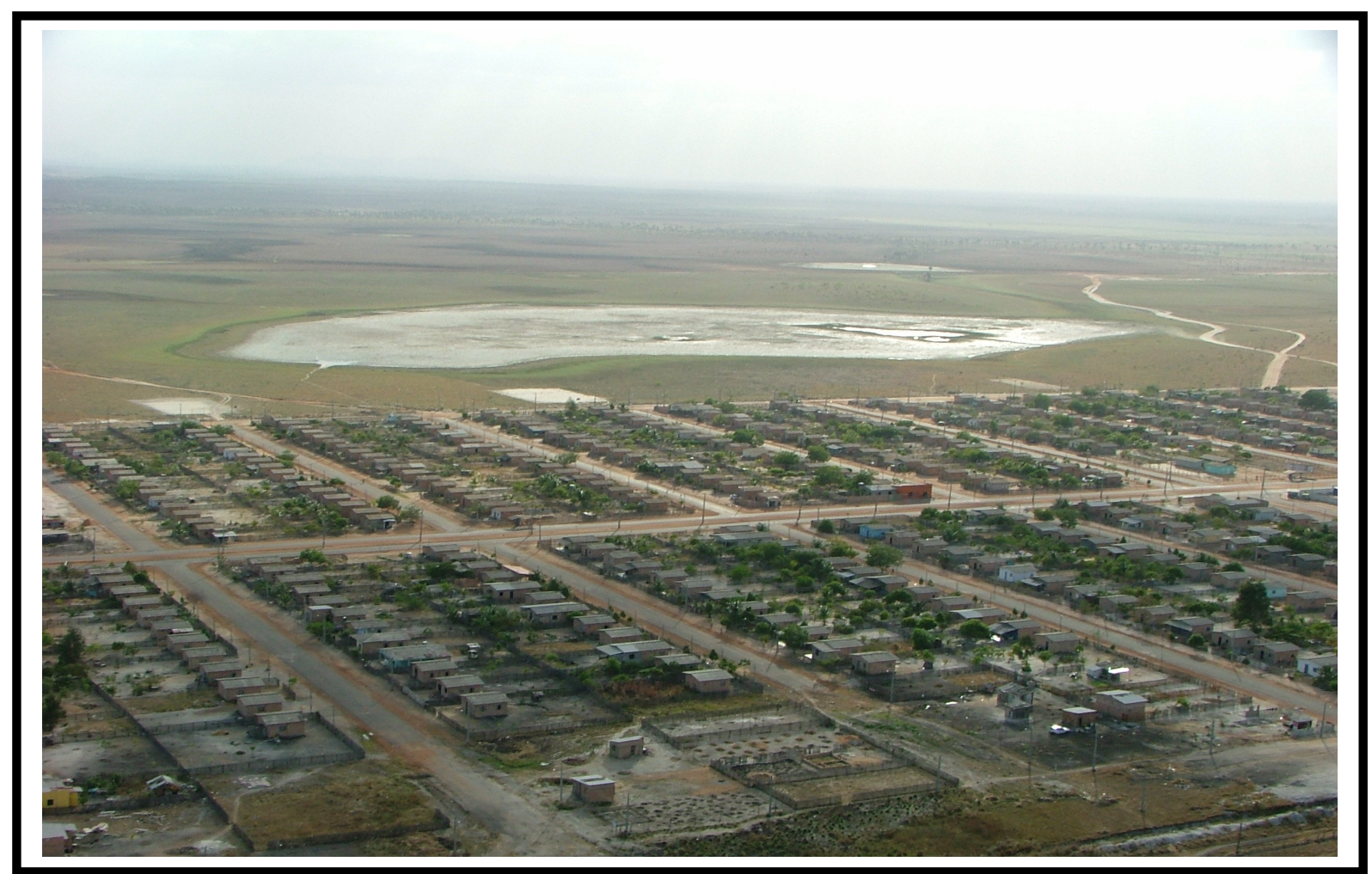

Figura 64: Conjunto Cidadão (Ao fundo nascentes de igarapés)

Foto: Acervo de Roberto CaleffilUFRR - 2008

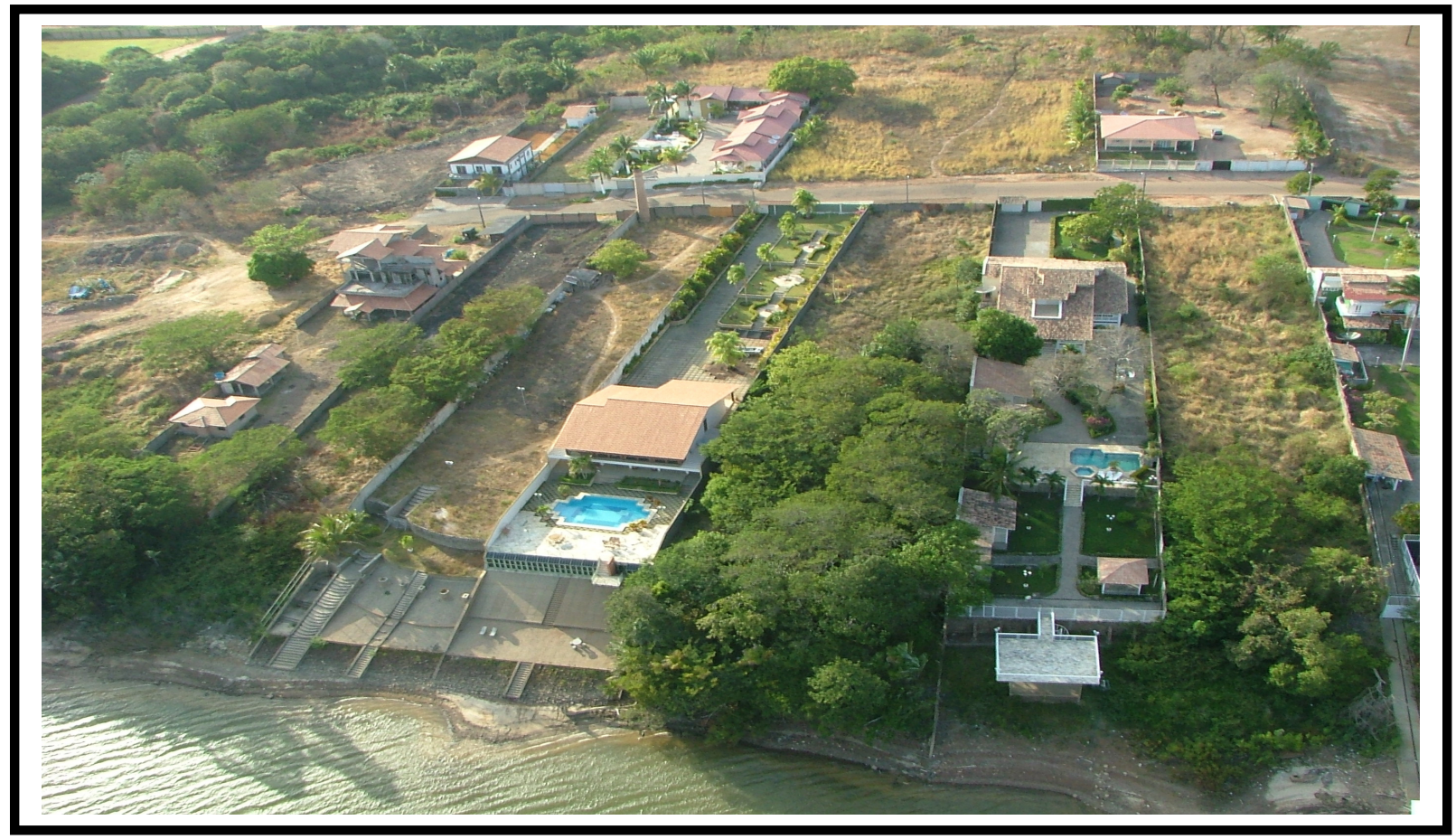

Figura 65: Casas de Alto Padrão de Luxo (Margens direita do rio Branco) Foto: Acervo de Roberto Caleffi UUFRR - 2008 
Outro agravante, na análise do COHRE (2005-2006, p. 41) que serviu para o IBAM e a prefeitura traçar políticas de regulamentação foi:

Que a maioria dos loteamentos populares não possui infra-estrutura adequada e $17 \%$ da população não tem nem latrina (banheiro, privada ou cloaca) [...] também, a presença de áreas irregulares ocupadas por população de baixa renda, como a Pintolândia, o bairro Brigadeiro - hoje São Bento, o bairro Operário, o loteamento Hélio Campos e o conjunto Cidadão [...] bem como, a existência de uma máfia de grilagem de terras, sobretudo nos loteamentos iniciados pelo Poder Público Estadual cujos lotes acabam sendo vendidos por políticos ou reservados por pessoas que vivem da venda dessas áreas para a população carente.

Comungando com o COHRE, o IBAM (2006, p. 1-32) constatou que o setor habitacional da cidade é carente de políticas públicas e estar abaixo do padrão desejável por apresentar as seguintes características:

a) Irregularidade na titulação dos imóveis;

b) Inconformidade com padrões mínimos de salubridade, conforto e segurança, nas edificações;

c) Condições inadequadas de urbanização, insuficiência de atendimento dos serviços de infra-estrutura; $e$

d) Insuficiência de equipamentos comunitários.

Essas informações nos levam a crer que as ações desenvolvidas pela Prefeitura Municipal de Boa Vista, expostas anteriormente, não foram suficientes para suprir a demanda habitacional e nem controlar o processo desordenado de uso e ocupação do solo urbano.

Contudo, na análise do IBAM (2006),

\begin{abstract}
Várias melhorias habitacionais têm sido executadas com a implantação de módulos sanitários em parceria com a Fundação Nacional da Saúde FUNASA e promovida a substituição de materiais de construção precários, como a madeira por alvenaria, mediante linhas de financiamento para aquisição de materiais de construção através de programas em parceria com a CAIXA ECONÔMICA e o Banco do Brasil.
\end{abstract}

No que concerne à infra-estrutura da cidade, o sistema de saneamento básico do Município é realizado pela Companhia de Águas e Esgoto de Roraima - CAER e abrange praticamente todas as residências com água potável fluoretada. Dados da CAER dão conta que a rede de água possui 64.870 ligações domiciliares e beneficia $98 \%$ da população da cidade. No entanto, paralelamente a estes sistemas, constatase que alguns munícipes fazem uso de "captações particulares" para abastecimento próprio, como é o caso do uso de poços e de captações superficiais das águas do rio Branco (IBAM, 2006). 
Já a rede de esgoto abrange $207 \mathrm{~km}$ de rede e 12.978 ligações domiciliares apenas, e estão conectados apenas a 13(treze) bairros próximos ao Centro. Os demais bairros, que correspondem a $70 \%$ da população urbana, utilizavam o sistema de fossa séptica ou "negra" (IBAM, 2006). O restante lança "in natura" nos corpos receptores e terrenos do município, como evidencia a Figura 66.

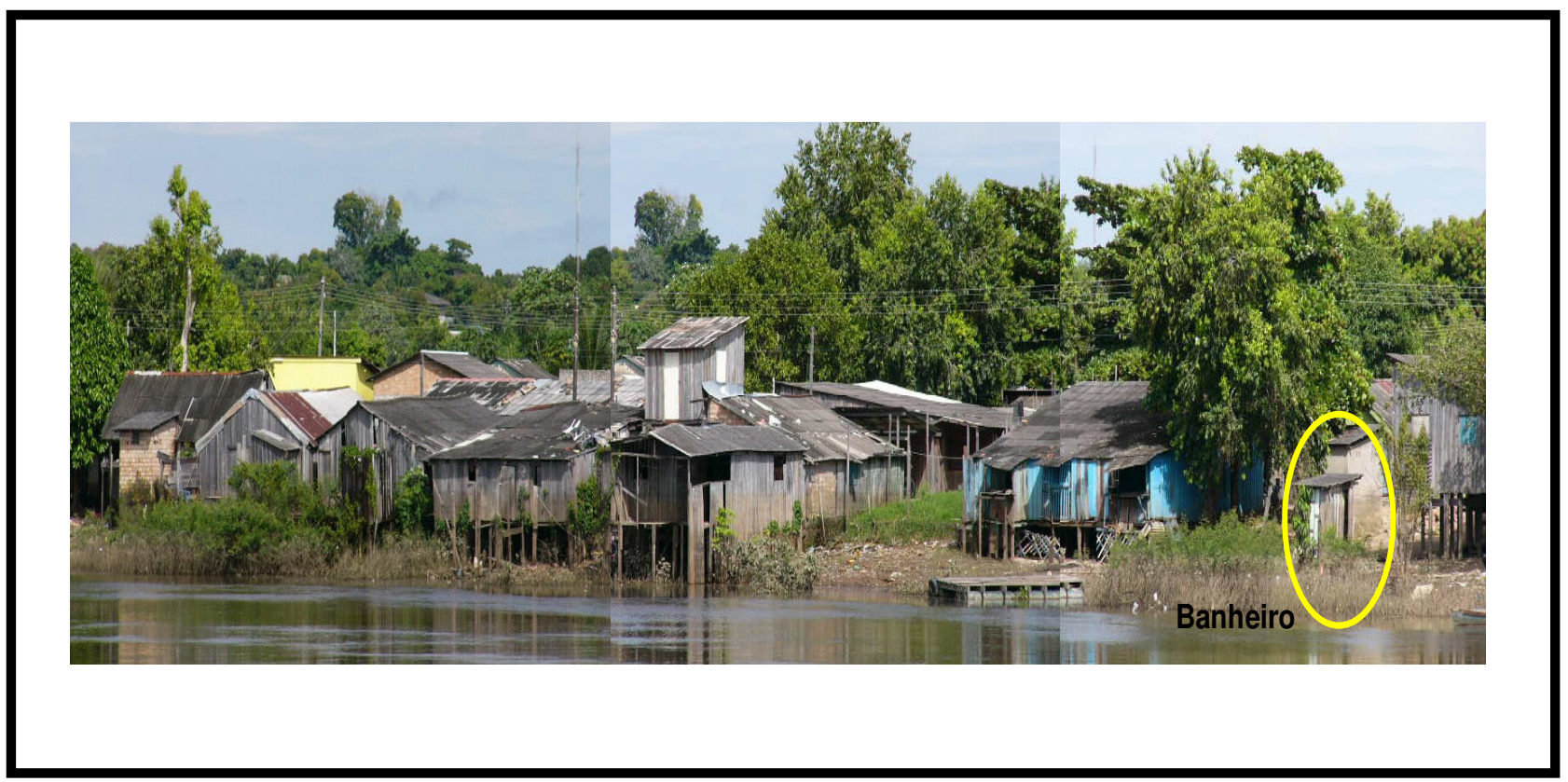

Figura 66 - Lançamento de esgotos "in natura" no Rio Branco (Bairro Caetano Filho \Beiral) Fonte: IBAM 2006

Diante da situação, o IBAM (2006, p. 279-295) incorporou ao Plano Diretor as seguintes sugestões propostas no estatuto da cidade: de abastecer $100 \%$ da população com água própria para consumo, com regularidade e com o mínimo de impacto ambiental possível; estabelecer metas progressivas de redução de perdas de água em toda a cidade; controlar o lançamento de cargas poluentes nos mananciais; inibir a confecção de poços freáticos (rasos) principalmente nas regiões onde não há rede coletora de esgotos; assegurar o fim das ligações clandestinas de esgoto nas redes de águas pluviais; criar um sistema de controle da qualidade da água e dos poços semi - artesianos; melhoria das vias de acesso, pavimentação e desobstrução de sistemas de drenagem; controlar o lançamento de cargas poluentes nos mananciais e promover parcerias com instituições públicas e privadas visando o esclarecimento da população com relação à correta instalação da fossa séptica e a necessidade de sua manutenção periódica. 
Já o sistema viário é composto por vias largas e, na sua maioria, possuem duas faixas por sentido. O volume atual de tráfego não exige que seja dada prioridade física ao transporte coletivo, como o uso de faixas e pistas exclusivas para ônibus, entretanto a prioridade operacional é recomendada (IBAM, 2006, p. 1-42).

No que tange ao terminal de ônibus João Firmino Neto, o IBAM (2006) esclarece que:

Apesar de ser muito bem construído a localização do terminal, no centro geográfico de Boa Vista, não parece ser a mais adequada. Desta forma, não atende as necessidades de deslocamento da população, que em sua maioria, se dirige ao centro da cidade. Através de entrevistas realizadas com usuários no terminal, foi possível identificar que algumas linhas sofreram fusão de itinerário e conseqüente aumento no tempo de viagem [...] $\mathrm{A}$ justificativa para dada pela EMHUR para a escolha do local é que a cidade cresce na direção do terminal e que o centro comercial tende a se deslocar para aquela área. Entretanto, enquanto esta mudança não acontece, a população é obrigada a enfrentar longos períodos de espera, a fazer baldeações e a realizar deslocamentos indesejados.

Com base nas informações acima, o IBAM (2006) propôs que fosse realizada uma pesquisa com o objetivo de mapear a origem e destino de passageiros, para identificar os eixos de mobilidade da população e desta forma adequar a rede de linhas de ônibus a realidade da cidade.

No que concerne ao setor de saúde, segundo o IBAM (2006, p. 12-13)

Boa Vista apresenta um sistema de atendimento médico-hospitalar saturado [...]. A Prefeitura, por meio da rede de atenção básica à saúde, atende em média cerca de $70 \%$ da população em suas unidades básicas e na unidade móvel. No entanto, há carência de algumas especialidades médicas e de centros de referência. A cidade conta com três hospitais estaduais, um federal e uma unidade mista, a Casa do Índio, que fazem atendimentos ambulatoriais e internações. Contudo, a concentração desses equipamentos em Boa Vista, faz com que a população do Estado de Roraima se desloque para essa área, superlotando e sobrecarregando o sistema de saúde.

Diante dos dados supracitados, o IBAM (2006, p. 1-16) incorporou ao Plano Diretor Estratégico de Boa Vista os seguintes objetivos:

- Promover o desenvolvimento econômico sustentável do município na perspectiva da integração regional;

- Qualificar o meio ambiente do município considerando sua biodiversidade e condicionantes socioeconômicas;

- Ordenar e estruturar o sistema urbano;

- Regularizar a situação fundiária e urbanística; 
- Promover e fortalecer os instrumentos de políticas setoriais (saúde e educação);

- Valorizar o patrimônio cultural evidenciando as identidades locais; e

- Fortalecer o sistema de planejamento e gestão municipal.

No que se refere ao macrozoneamento urbano(Mapa 15) e para fins de aplicação das normas de uso e ocupação do solo em seu Capítulo III e Art. 4 e 5, os terrenos incluídos nos limites do perímetro urbano do Município de Boa Vista, segundo o IBAM (2006), deverão ficar divididos em:

I. Área Urbana Parcelada (AUP): apresenta diferentes graus de consolidação e qualificação e se divide em zonas para orientar 0 desenvolvimento urbano;

II. A Zona Central (ZC): tem como objetivo reforçar a permanência de usos comerciais e institucionais que atribuem características de centralidade à área e preservar o traçado do Plano de Boa Vista, assegurando a ambiência da área com a manutenção do parcelamento do solo e volumetria atual dos prédios;

III. As Zonas Residenciais (ZR's): têm como objetivo compatibilizar usos e atividades, incentivar a ocupação de lotes vazios nas áreas dotadas de infra-estrutura e definir parâmetros de ocupação que considerem as condições físico-ambientais;

IV. Os Eixos Comerciais e de serviços (ECS's): tem como objetivo incentivar a concentração de usos e atividades comerciais e de serviços que apresentem complementariedade;

V. A Zona Industrial (ZI): tem como objetivo a manutenção do uso, desde que restrito, definindo as atividades industriais compatíveis e não compatíveis, frente às características ambientais da área;

VI. As Zonas Institucionais (ZIL's): têm como objetivo a manutenção dos usos institucionais e formas de parcelamento atuais; $e$

VII. Área Urbana de Expansão (AUE): subdivide-se em duas áreas descontinuas:

a) AUE 1 - destina-se à implantação de novos loteamentos.

b) AUE 2 - de interesse funcional, voltada para implantação de equipamentos de porte médio e grande porte como: cemitério, garagens, galpões, indústrias. 


\section{Mapa 15: Macrozoneamento urbano de Boa Vista}

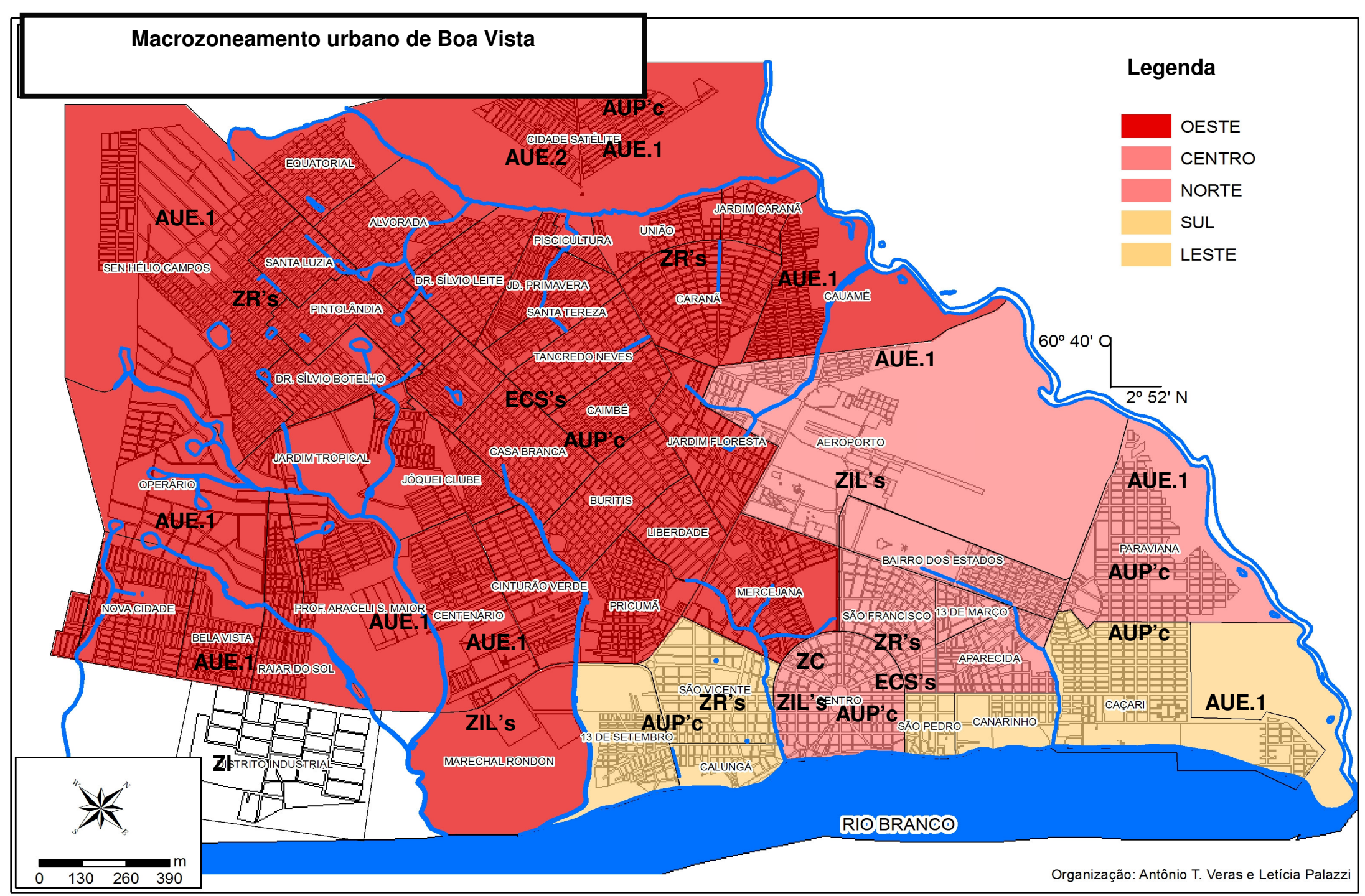

Legenda: AUP'C - Área urbana parcelada consolidada \AUE - Área urbana de expansão (AUE.1 - destinado a implantação de loteamentos AUE.2 - de interesse funcional voltado para implantação de equipamentos de médio e grande porte: cemitério, indústrias, galpões etc). $\backslash$ ZC - Zona central $\backslash$ ZR's Zonas residenciais \ECS's - Eixos comerciais e de serviços \ZIL's - Zonas Institucionais \ZI - Zona Industrial. Fonte: IBAM, 2006. 
Convém esclarecer que o Plano Diretor Estratégico de Boa Vista estabelece uma agenda de revisão de toda a legislação urbanística municipal. O grande desafio é preceder esta revisão, na perspectiva de facilitar a promoção imobiliária e baratear a produção habitacional sem afetar a qualidade urbana e ambiental da cidade, e criar uma legislação objetiva, clara e de fácil aplicação, que possa contribuir para romper o ciclo de ilegalidade e conflitos que tem caracterizado o processo de uso e ocupação do solo em Boa Vista. "Um grande desafio para o século XXI é simplesmente garantir o cumprimento da legislação" (BONDUKI, 2007, p. 241)

$\mathrm{Na}$ nova legislação urbanística, incluem-se as Zonas Especiais de Interesse Social - ZEIS -, que representa o reconhecimento da diversidade das ocupações existentes na cidade e a possibilidade de construção de uma legalidade dos assentamentos, tanto na qualificação e regularização das áreas periféricas, como foi o caso do Conjunto São Bento, quanto na democratização do acesso à cidade provida de infra-estrutura, regulando a atuação do mercado imobiliário.

Para Ferreira \& Motisuke (2007, p. 34), com a regulamentação das ZEIS, no Estatuto da Cidade, junto com os demais instrumentos urbanísticos lá contidos, criou-se uma grande expectativa quanto à possibilidade de que os municípios passem a contar com uma maior capacidade de controle sobre o processo de produção e apropriação do espaço, fazendo valer a função social da propriedade urbana.

Ainda segundo Ferreira \& Motisuke (2007, p. 46)

As ZEIS têm sido consideradas o mais adequado instrumento urbanístico a ser utilizado para viabilizar a regularização fundiária e urbanística de diferentes tipos de núcleos e áreas de ocupação precária da população de baixa renda, como também para facilitar e incentivar a produção de novas moradias.

Outro instrumento incorporado à legislação urbanística de Boa Vista foi o direito de Preempção e a Outorga Onerosa, úteis na aquisição de imóvel urbano para fins de melhoria das condições sociais no controle do adensamento urbano, na utilização desordenada dos lotes sem atenção aos equipamentos urbanos existentes, e, finalmente sem a necessidade de vultosas expropriações, inclusive para o estabelecimento de áreas verdes e a implantação de equipamentos comunitários. 
Desta maneira, é imprescindível que a sociedade cobre de seus representantes, nas três esferas do poder: Federal, Estadual e Municipal, que as leis sejam cumpridas em favor do desenvolvimento urbano da cidade de Boa Vista. Pois, ao longo de sua formação sócioespacial, foi sujeita a diversas ações normativas de interesse particulares e políticos que não respeitaram o direito à cidade por parte da população em geral.

\subsubsection{A questão fundiária urbana x planejamento urbano}

A regularização fundiária urbana é um problema que se configura em todo o processo de formação sócioespacial do Estado de Roraima e que se acentua até os dias atuais.

Num ensaio sobre a questão fundiária rural-urbana no estado e município de Boa Vista, o advogado e membro da Coordenação do Núcleo de Assentamento Jurídico da Prefeitura Municipal de Boa Vista, Senhor Walter Jonas Ferreira da Silva (2006, p. 12-30), afirma que até os dias atuais o panorama de incerteza sobre a extensão territorial do Estado de Roraima e do município de Boa Vista é confuso em decorrência da ausência de uma política de gestão territorial e de segurança jurídica do patrimônio territorial. Sem essa incorporação subjetiva, qualquer programa e projeto de planejamento e desenvolvimento urbano é levado ao fracasso.

Cabe enfatizar que, no processo de criação do território, não houve a legalização das terras urbanas municipais, isto é, o município de Boa Vista não detém terras sob seu domínio, mesmo as originárias do estado do Amazonas adquiridas pela antiga Intendência Territorial do Rio Branco, a depender, no entanto, de homologação do Instituto Nacional de Colonização e Reforma Agrária - INCRA. Esse agravante histórico e jurídico na concepção dos órgãos fundiários locais acarreta na ausência de políticas de desenvolvimento urbano. Pois, não existindo uma legitimidade sobre a terra, o gestor não poderá propor políticas de planejamento urbano e obter recursos financeiros para suprir as demandas de amenidades que a cidade venha a exigir (SILVA, 2006, p. 30-40).

Tal fato reflete no desordenamento urbano e na forma de uso e ocupação do solo urbano de maneira irregular por especuladores particulares, imobiliários e grupos sociais, entre outros. Bem como, reflete no surgimento e expansão de loteamentos e habitação em desacordo com o planejamento urbano da cidade, o 
que dificulta a priori aos órgãos gestores do município (re) ordenar seus espaços através de programas e projetos sociais e de desenvolvimento urbano (SILVA, 2006, 42-48).

Para o Estado, persiste a complexa indefinição das terras, a partir da transformação do ex - Território, vez que o processo de criação do novo Estado pela Constituição Federal de 1988 não foi acompanhada da identificação e respectiva transferência de áreas ao seu domínio (SILVA, 2006, 49-64).

Conforme Silva (2006),

[...] O presente quadro tem limitado, também, a aplicação dos mecanismos creditícios e os investimentos públicos e privados, impedindo de se efetivar em sua plenitude as perspectivas otimistas de desenvolvimento rural e urbano e de fomento as atividades econômicas por parte das Agências de Fomentos e dos gestores estaduais e municipais em seus programas de desenvolvimento sustentáveis [...]. No caso do Município, a transferência da área sede e de expansão urbana, é fundamental para a implementação de um novo Plano Diretor Estratégico, objetivando a eficácia ao reordenamento desse espaço urbano, além de conferir maior e mais rápida implantação de seus programas urbanísticos, como instrumento de reorganização territorial e de justiça social, visa, entre outros, o de permitir a segurança jurídica imprescindível ao detentor do domínio de lotes urbanos. [...] a transferência de terras ao Município, é imprescindível para um programa definitivo de destinação de áreas urbanas e rurais e daquelas a serem incorporadas ao patrimônio imobiliário do Município, cuja destinação, torna - se fundamental para implantação de programas e projetos de desenvolvimento agrícola voltados à agricultura familiar, além do ordenamento do espaço urbano da sede da capital.

Há tempo faz-se necessário que as instituições públicas a nível Federal, Estadual e Municipal unam forças, sem interesses particulares e políticos, para solucionar o problema e promover um amplo debate com a população sobre a cidade que queremos. Ação que deve contar com definições claras sobre a realidade urbana de Boa Vista e excluir por completo os interesses imobiliários e as demagogias políticas que, em muitos casos, buscam favorecimento próprio.

Pensando em amenizar o problema, a prefeitura, por meio da Procuradoria Geral da União e da EMHUR, realizou cadastramento e levantamento topográfico dos lotes urbanos para regularizá-los. Em 1994, foram executados 300 levantamentos topográficos, 300 memoriais descritivos e 300 plantas de quadra urbanas de Boa Vista. (PMBV, 1993-1996, p. 131). Vale ressaltar, que existe um processo tramitando na esfera jurídica do Estado para regularizar as áreas urbanas do município. 


\subsection{Rugosidades e tendências atuais na dinâmica urbana de Boa Vista}

Considerando que os primeiros agentes promotores do atual espaço urbano de Boa Vista, foram os fazendeiros, os religiosos, os militares, as famílias influentes, a ação garimpeira e o Governo Federal. Seguidos destes, o poder Estadual, Municipal, os comerciantes e, que as principais mudanças sócioespaciais da cidade aconteceram com maior intensidade na década de 1940 com a criação do Território Federal do Rio Branco a partir do município de Boa Vista.

Somos levados a retroceder no tempo e (re) lembrar que a expansão territorial urbana de Boa Vista se deu inicialmente na margem direita do rio Branco, que, por sua vez, serviu de atrativo para a implantação das primeiras edificações públicas e residenciais da cidade e atualmente permanece como uma área de alto valor imobiliário, tendo como fator preponderante o rio Branco e sua beleza natural. Como mostra a Figura 67.

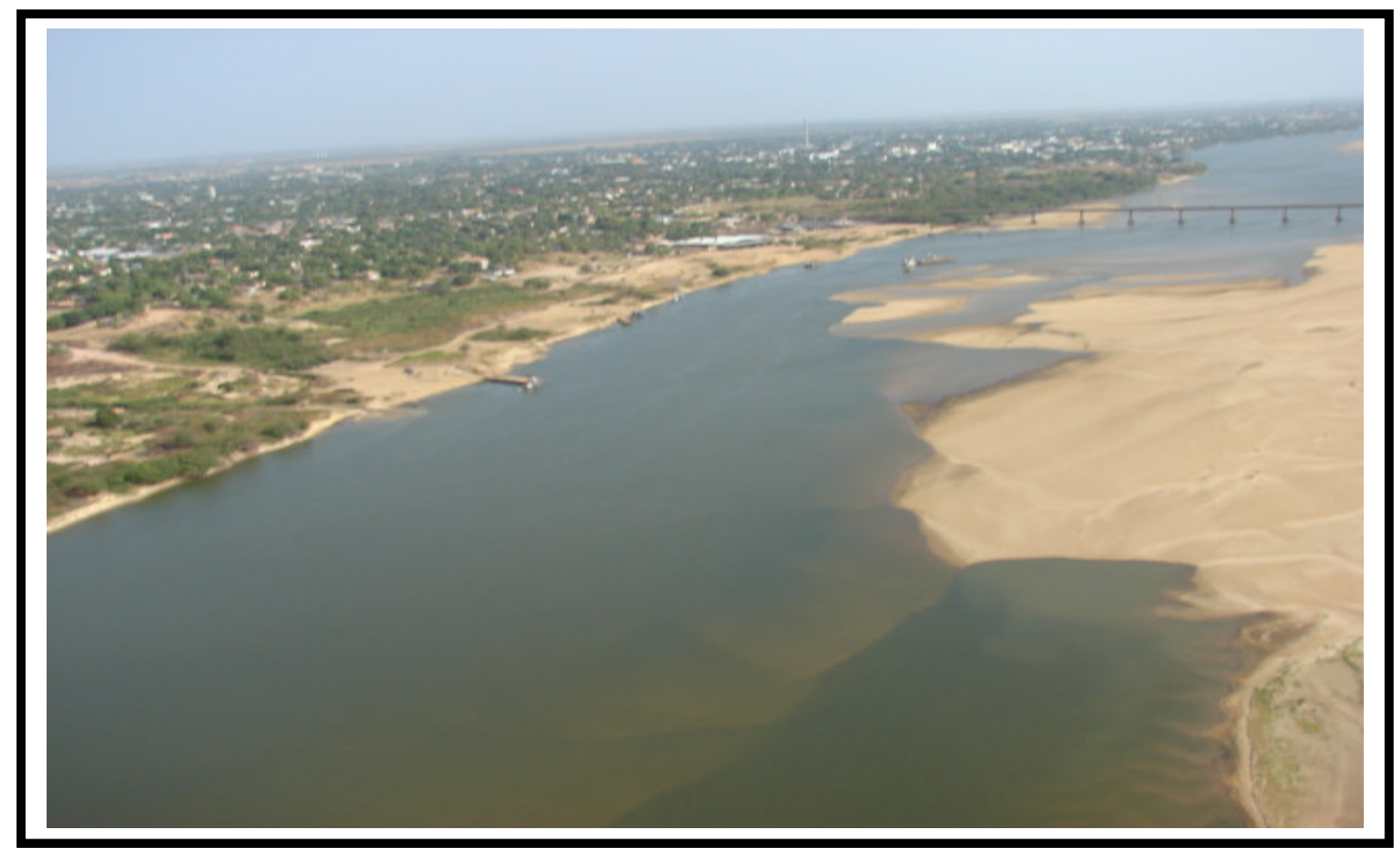

Figura 67: Vista aérea da margem direita do rio Foto: Acervo de Roberto CallefilUFRR - 2007 
A forma da mancha urbana de Boa Vista, ao longo do século $X X$, atingiu um crescimento espacial significativo. A área inicial e também a que se apresenta até 0 ano de 1944, era um pequeno aglomerado urbano que podemos denominá-lo de núcleo embrionário pré-existente. Foi a partir dele que se deu a implantação do Projeto Urbanístico de Darcy Aleixo Derenusson com a ação política do primeiro governador do Território Êne Garcez. Em meados da década de 70 (setenta) do século XX, a mancha urbana se restringia, aproximadamente, ao localizado entre o aeroporto internacional de Boa Vista, a Avenida Venezuela, o rio Branco e o igarapé Mirandinha (Mapa 16).

A partir da década de 80 e 90 e principio do século XXI, forma-se um tecido urbano que ultrapassa as expectativas de desenvolvimento urbano, tendo uma direção principalmente no sentido Oeste, em detrimento das outras zonas urbanas locais, onde, esse crescimento ocorreu de forma bem menos intensa (Mapa 16).

Destacamos que, dentro desse crescimento, ocorreu o principio da dispersão do tecido urbano com a criação de novos bairros, em sua maioria, decorrentes de ocupações irregulares, próximo aos principais igarapés que cortam a cidade e a margem direita do rio Branco.

Acrescentamos que, no decorrer dos primeiros anos do século XXI, o tecido urbano de Boa Vista continua tendo alterações, obrigando a existência de novas formas de análise sócioespaciais. Essa dinâmica, na concepção de Reis (2006, Apud SILVA e VERAS, 2008, p. 3-7) é, “(...) uma definição geométrica de relações de propriedade e uma definição social das formas de uso"; que obteve diferentes formas que concretiza Boa Vista como um lugar formado por um traçado de ruas e bairros que são identificados como em zonas, sendo estas norte, sul, Leste e Oeste de acordo com o Plano Diretor de Boa Vista de 2006 e, que concentra, atualmente, cerca de cinqüenta e três bairros (Mapa 16). 
Mapa 16: Dinâmica da produção do espaço urbano de Boa Vista

(Área inicial até 2008)

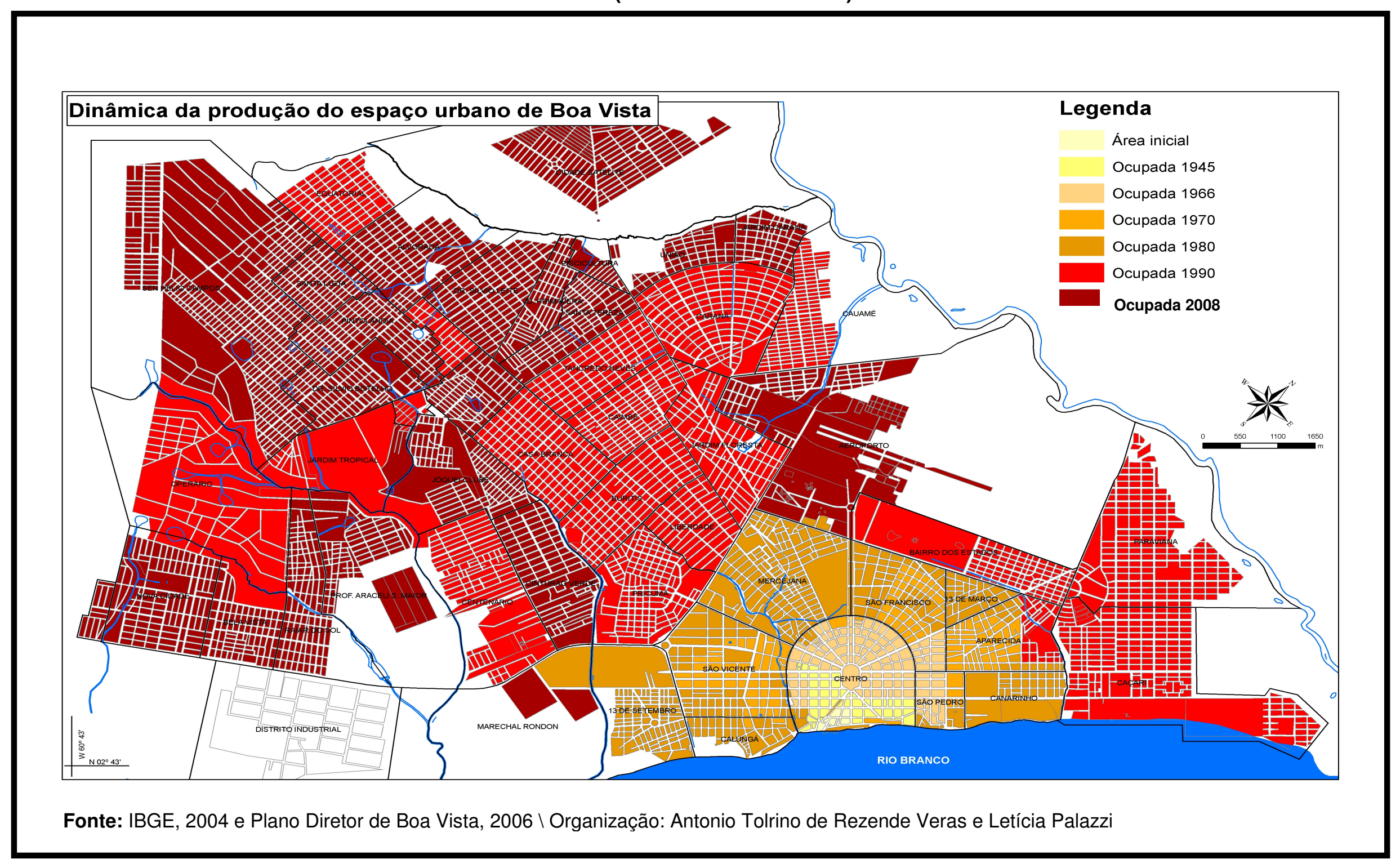


Salientamos que, nessa análise se deve acrescentar não só o crescimento espacial, mais também o demográfico, pois dados do IBGE de 2004 já revelavam que a população do município de Boa Vista era de 236. 319 habitantes, destes 198.098 estavam concentrados na área urbana. Contribuindo, desta forma, para uma maior fluidez na cidade e exigindo do poder público novos investimentos em equipamentos e serviços.

Desta maneira, são as relações entre a dinâmica do espaço e o crescimento da população que vão delinear as formas e os conteúdos da desigualdade sócioespacial.

Essas transformações variam no tempo e de acordo com as ações dos agentes espaciais no processo de reprodução continuada da cidade, transformando usos e funções e trazendo, como conseqüência, a destruição dos referenciais urbanos e das antigas relações sociais (CARLOS, 2003, p. 77).

Assim, o processo de urbanização de Boa Vista transformou o seu conteúdo, revelando-a numa prática sócioespacial modificada a partir de um jogo de interesses políticos, econômicos e sociais definidos, que não só redefiniu o seu traçado urbano, como também, a hierarquia dos lugares em função das exigências da vida cotidiana.

Para Guidugli (1979, Apud NUNES, 2007, p. 25) esse processo está Associado ao conjunto de variações do espaço, em que se presenciam as
exclusões de densidades residenciais, de população, de circulação, de
redistribuição de atividades, de despovoamento setorial e de alterações nas
estruturas etárias para as diferentes parcelas do território urbano [...]. No
conjunto verifica-se que dentro das cidades, um elenco de forças sociais,
culturais e econômicas atua de forma associada, produzindo um vasto
mosaico onde, cada parcela do território exibe texturas variadas de
população.

Percebe-se, portanto, que a dinâmica urbana atual de Boa Vista se faz por meio do processo de reprodução, tanto no plano espacial, como na dimensão econômica e político-estratégica e no plano da vida cotidiana da população.

A prática sócioespacial da cidade se revela nos modos de uso, pelo conteúdo das relações sociais, e no empobrecimento destas relações associadas à estruturação espacial pretérita e contemporânea, e à organização pré-existente do espaço urbano local. Os atores envolvidos nesta dinâmica incorporam em suas formas de uso do solo urbano, modernas técnicas de organização de consumo da cidade, criando áreas nobres em algumas zonas - como exemplo, a zona Leste da cidade - já citada -, que apresenta em seu traçado urbano uma rede de sistemas de 
engenharia (vias, redes de água, esgoto, pavimentação, energia etc), bem como possibilidades de transporte de produtos de um ponto a outro, de deslocamento de pessoas e de comunicação. Diferentemente do setor Oeste, que concentra o maior número da população de baixa renda, desprovida desses mesmos sistemas de engenharias.

Tal (des) ordenamento é fruto de políticas advindas de tempos desiguais; de traços nacionais definidores da estrutura; dos conflitos de classe ao longo de sua história de dominação política, econômica (segregação) e ideológica (Figura 68).

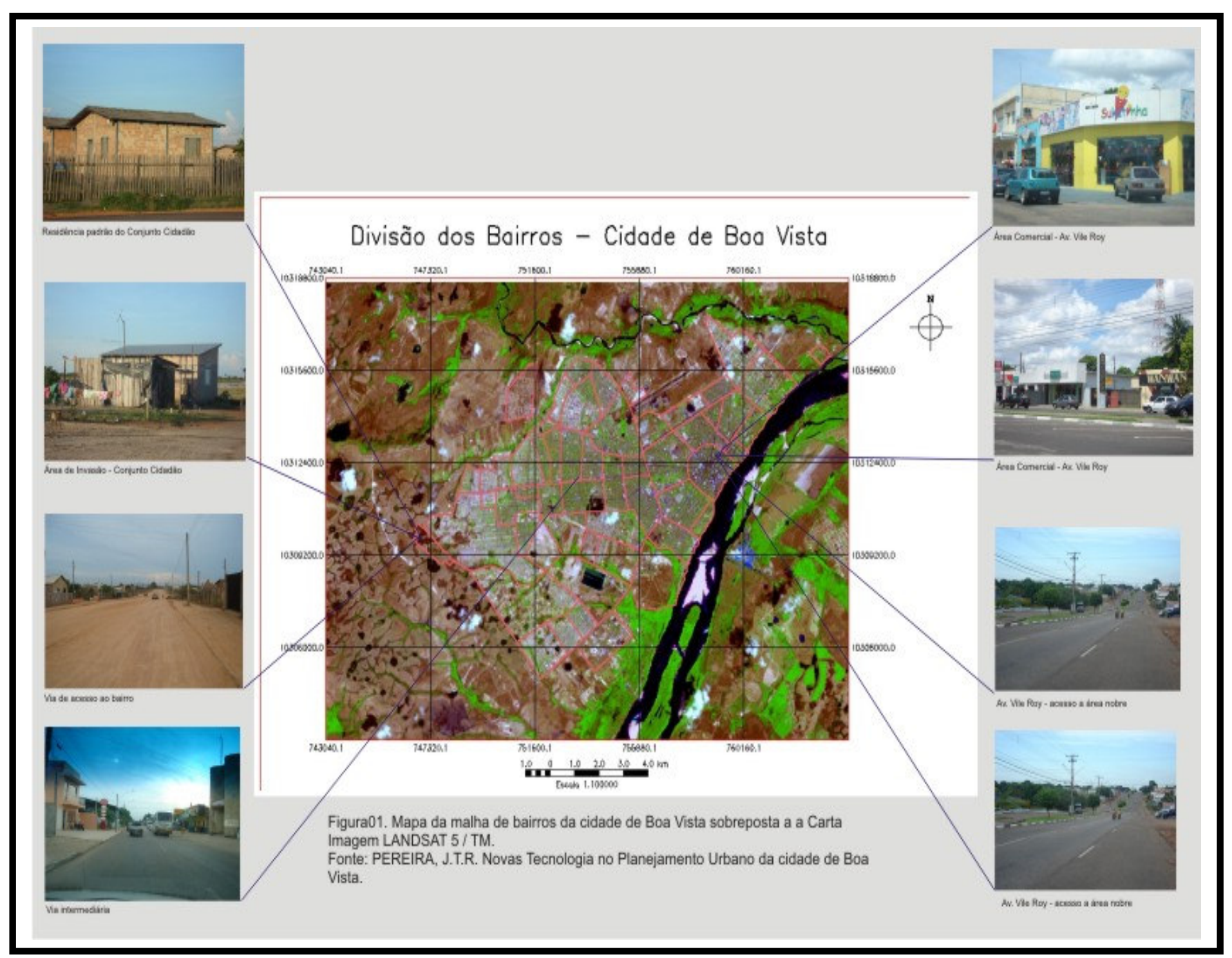

Figura 68: Zona Leste e Oeste da cidade de Boa Vista Fonte: PEREIRA, 2005. 
Nessa dinâmica de produção a cidade apresenta uma nova forma de organização, trata-se da fragmentação e dispersão comercial, típicas do processo contemporâneo de expansão das cidades. Áreas onde, até então, afirmava-se o sentido de centralidade comercial - bairro centro -, seja em função do seu significado histórico, seja em conseqüência da proximidade de bens e serviços, passam a perder força em conseqüência de novos fatos, entre os quais: o surgimento de novos bairros afastados do centro, aliado ao difícil acesso da população ao setor comercial da área central em função da precariedade do setor de transporte coletivo de Boa Vista; a busca de novos mercados consumidores onde se concentra a população em maior número - no caso -, a zona Oeste; a mão-de-obra barata; o preço do imóvel em relação à área central e adjacências, que é bem inferior; e o surgimento de subcentros comerciais espontâneos. Como foi o caso do subcentro da Avenida Ataíde Teive (Figura 69).

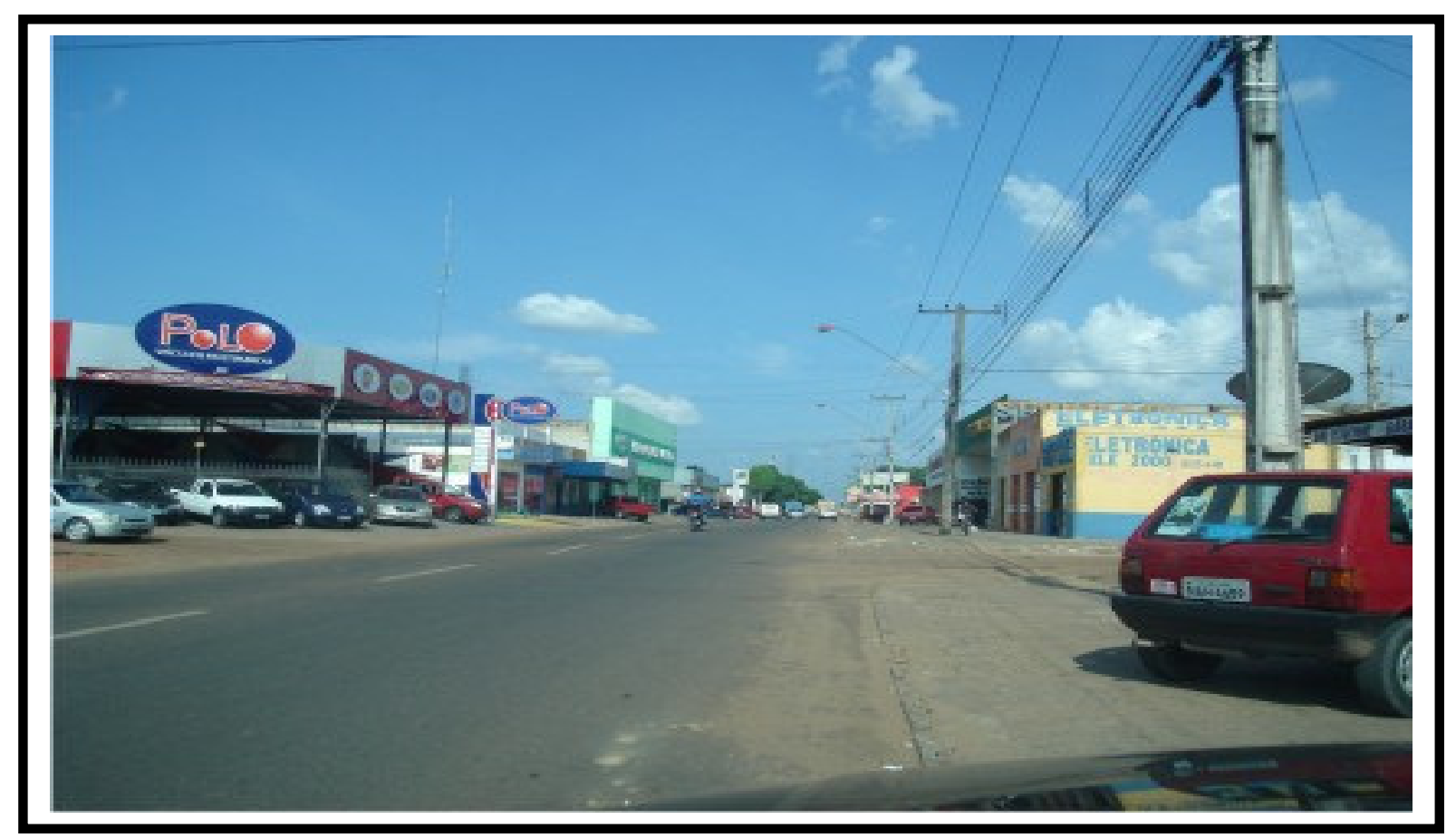

Figura 69: Subcentro comercial - Avenida Ataíde Teive

Foto: Acervo de Jõao Theófilo R. Pereira $\backslash 2008$

Diante dessa nova realidade a atividade comercial passou a procurar novos eixos de centralidade (dispersão) e (re) localização nas principais avenidas e ruas da cidade. Em especial as localizadas no setor Oeste da cidade e no entorno do centro indutor comercial de Boa Vista (bairro centro e adjacências), como mostra o Mapa 17. 
Mapa 17: Dispersão comercial de Boa Vista

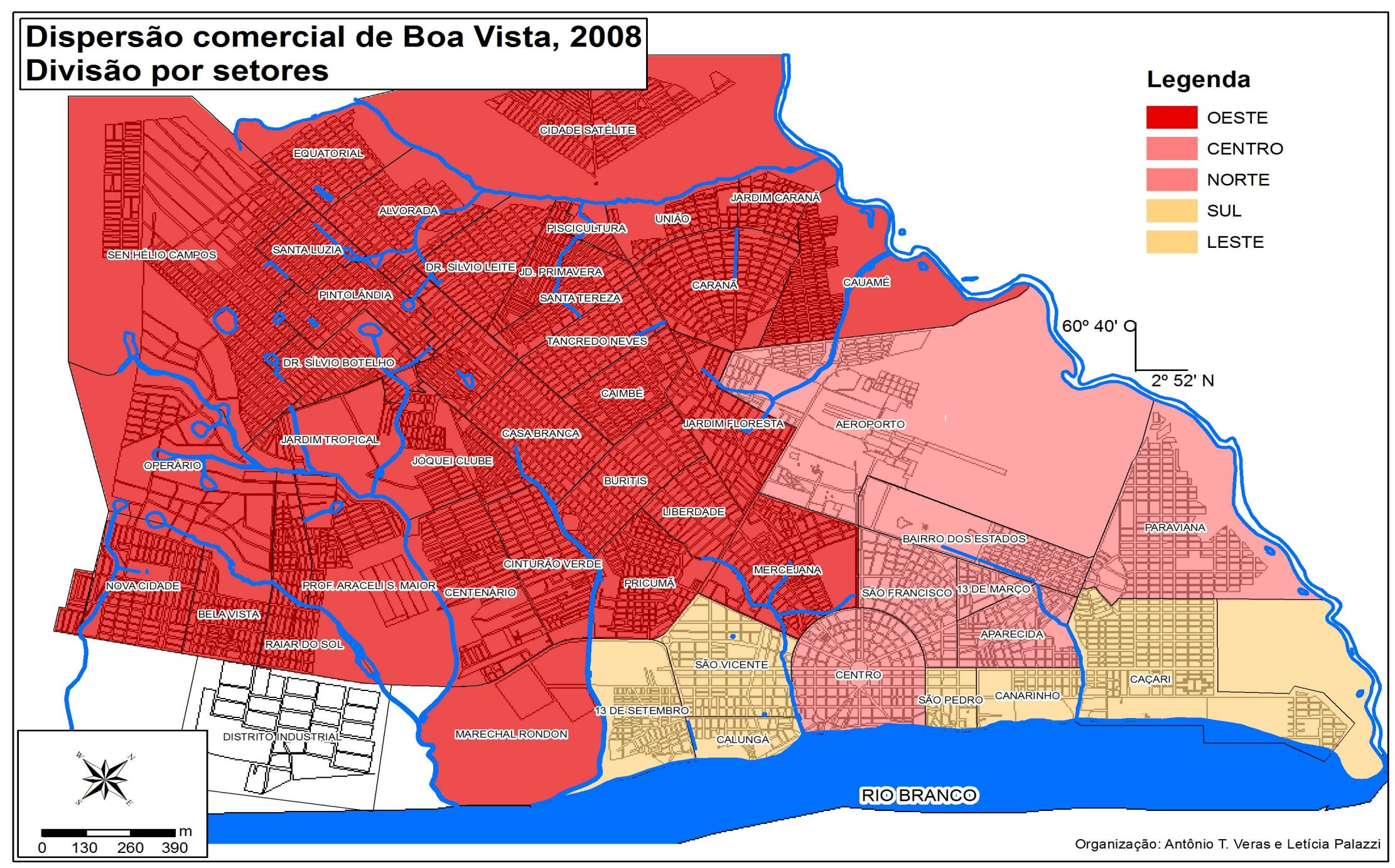


Desta maneira, as alterações no plano da sociedade se revelam enquanto mudanças espaciais, em particular as transformações ocorridas nos diversos subespaços da cidade, que apontam para a diminuição da importância do centro histórico-comercial de Boa Vista, tanto do ponto de vista de sua produção, quanto na oferta de emprego, pois sua dispersão produz novos eixos de circulação, com novas formas e funcionalidades no processo de estruturação da cidade.

Conforme Corrêa (1990, p. 54), estes objetos fixos ou formas dispostas espacialmente estão distribuídos elou organizados sobre a superfície da terra de acordo com alguma lógica. Segundo o autor, o conjunto de todas essas formas configura a organização espacial da sociedade na atual temporalidade.

Para Carlos (2003, p. 78), "o conteúdo da urbanização, neste caso, apareceria como momento determinado da reprodução em função das novas possibilidades/necessidades de realizar a acumulação".

Considerando o exposto por Corrêa (1990) e Carlos (2003), a nova divisão espacial do trabalho na cidade de Boa Vista apresenta-se com uma nova feição espacial, na qual a infra-estrutura é capaz de absorver novas formas de produção e novas funcionalidades em função de sua capacidade de concentrar novos padrões de consumo. Um exemplo é a concentração de lojas de alto padrão na Avenida Ville Roy.

Caracterizada por ser uma das avenidas mais antigas da cidade de Boa Vista. Foi planejada com padrão de avenida de 20 metros de largura, conforme a divisão de estudos e projetos urbanísticos da Prefeitura de Boa Vista. É uma avenida larga, asfaltada, com calçamento e arborizada; possui coleta diária de lixo feita pela prefeitura municipal; tem sistema de esgoto, água encanada e tratada pela Companhia de Água e Esgoto de Roraima, e é bastante iluminada, principalmente onde se localiza as principais lojas (LAURIANO, 2005, p. 25-26) (Figura 70). 


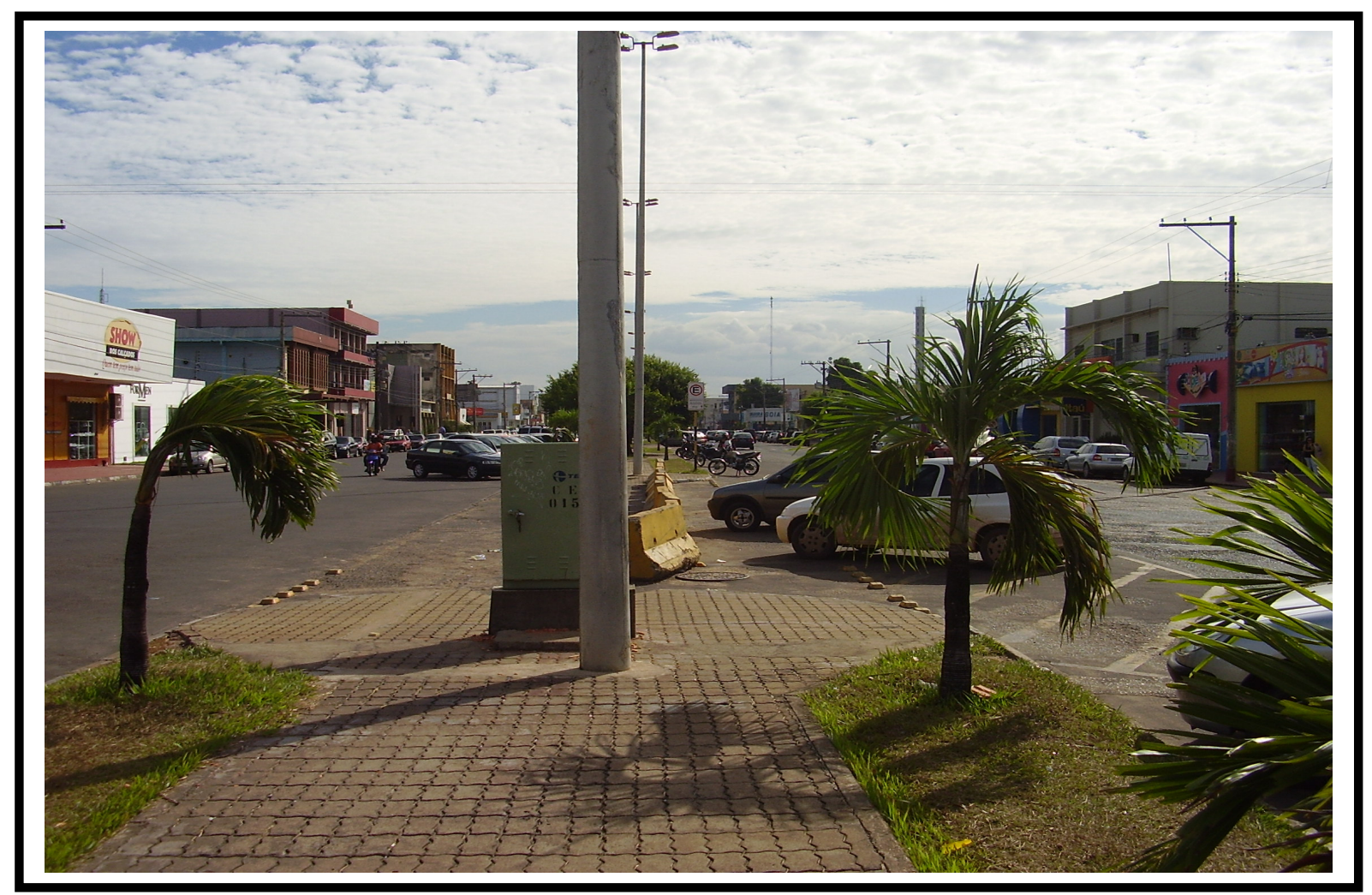

Figura 70: Avenida Ville Roy

Foto: Acervo de Antonio Tolrino de Rezende Veras

$\mathrm{Na}$ avenida, também, concentram-se instituições financeiras e órgãos públicos como o Banco do Brasil S.A, Instituto Nacional de Colonização e Reforma Agrária - INCRA, o Instituto de Terras de Roraima - ITERAIMA, a Procuradoria Geral do Estado, e em pequena escala as residências.

Vale destacar que, por ser uma radial e interligar-se com outros bairros centrais da cidade, a avenida tem ao longo dos anos, despertado interesse de investidores, em particular de especuladores financeiros e imobiliários.

Conforme Lauriano (2005, p. 27), num tempo mais recuado, a área comercial de Boa Vista concentrava-se especificamente na Avenida Jaime Brasil (Figura 71) Centro, mais precisamente na zona Leste da cidade. Com o processo de urbanização decorrente do inchamento de pontos comerciais do centro associado à procura de novos consumidores de maior rentabilidade, o setor comercial da cidade passou a incorporar novas práticas econômicas e a criar novas demandas de áreas comerciais, utilizando os subespaços existentes nas principais avenidas e ruas da respectiva zona da cidade. 


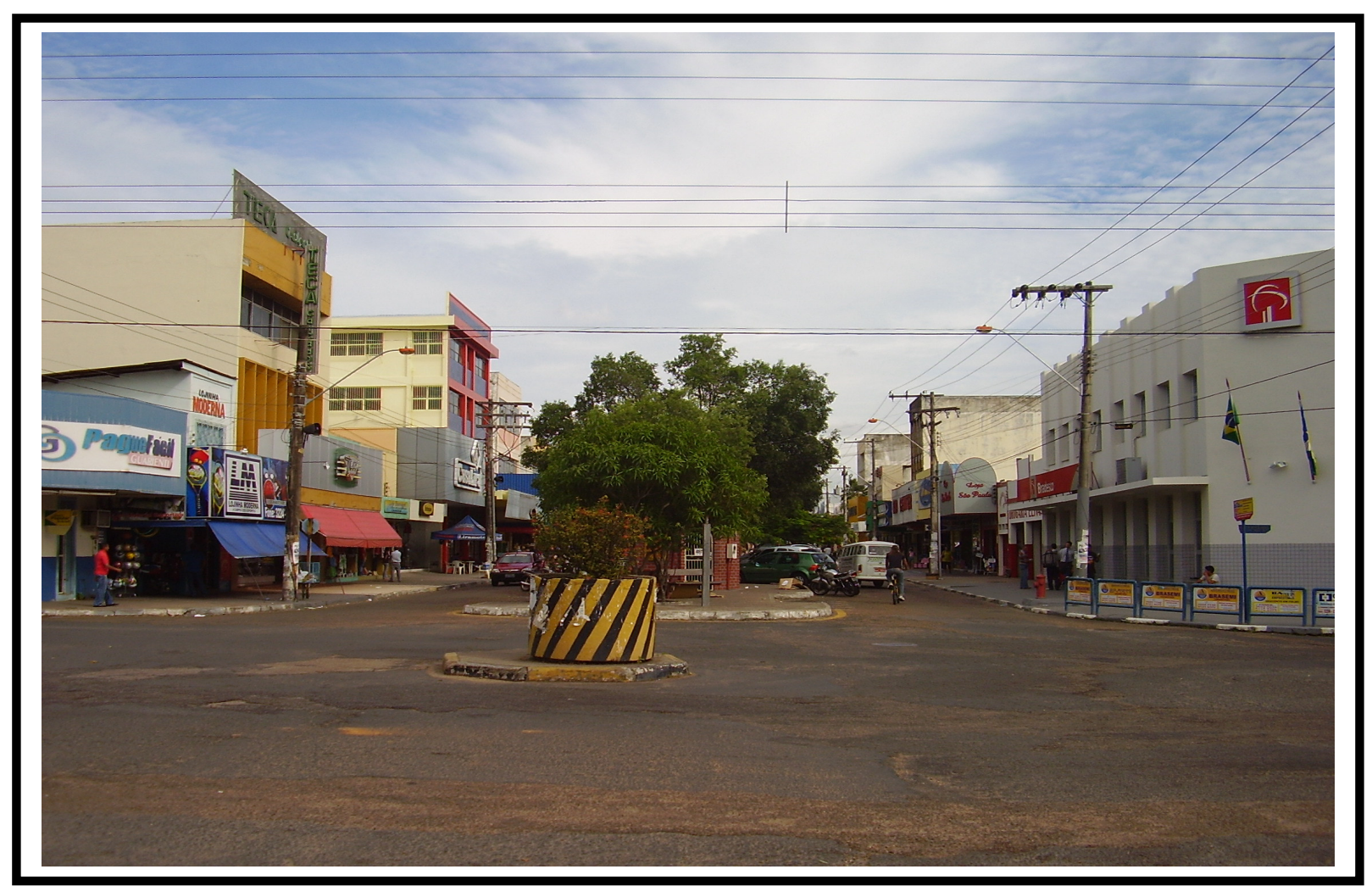

Figura 71: Avenida Jaime Brasil (área comercial) $\backslash 2009$

Foto: Acervo de Antonio Tolrino de Rezende Veras

Neste caso, segundo Carlos (2007, p. 65), "a cidade é sempre uma organização dinâmica, de alto poder concentracional, que cria, no entanto, a cada momento uma produção espacial que Ihe seja peculiar".

No caso empírico analisado no presente estudo, há uma mudança qualitativa dos tipos de serviços que passam a existir e que se volta para uma clientela selecionada e bastante diferente daquela que residiam nessa área antes do processo de urbanização. Um caso notório são as instituições superiores privadas e públicas, já mencionadas anteriormente, que se instalaram em diversos subespaços da cidade, em particular em áreas de padrão médio e de alto padrão, que proporcionaram uma nova redefinição desses espaços no contexto da divisão social, como também da divisão econômica do espaço.

Constata-se que a instalação dessas instituições deu um impulso no mercado imobiliário da cidade, uma vez que as áreas localizadas em seu entorno passaram a ser especuladas e, ao mesmo tempo, influenciaram a construção de edifício, condomínios e residências para suprir a demanda dos que fazem uso desse serviço. Isso se explica, também, pela própria localização privilegiada das instituições que dispõe de fácil acesso e de bens e serviços urbanos necessários ao bem estar social (Figura 72). 


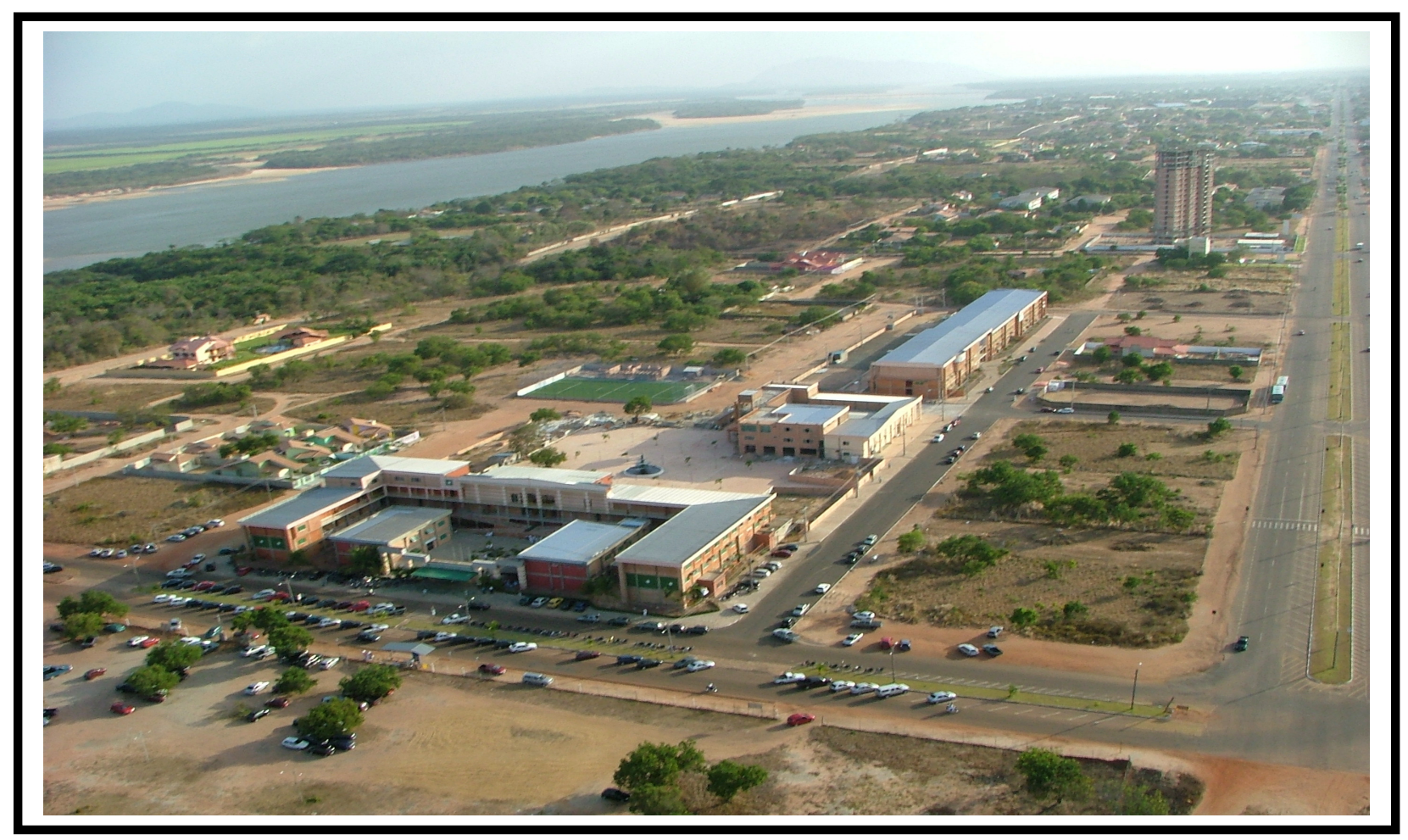

Figura 72: Faculdade Cathedral (Bairro Paraviana)

Foto: Acervo de Roberto Caleffi UUFRR - 2008

Nessa dinâmica de reprodução do espaço urbano, velhas formas desaparecem para dar lugar a novas formas exigidas por novas atividades. É assim que novas áreas ganham novos conteúdos e a atuação das imobiliárias passa a ser mais acirrada. Em particular quando se tratar de áreas valorizadas. Como foi o caso do lançamento dos loteamentos River Park I e II, cujos lotes variam de $600 \mathrm{~m}^{2}$ a $887 \mathrm{~m}^{2}$ e são vendidos por preços que variam de $R \$ 30.000,00$ a $R \$ 40.000,00$, bem como o prédio de apartamentos de luxo com 18 pavimentos, o "Residencial Varandas do Rio Branco" (Figura 73), cujas 36 unidades possuem área média de $180 \mathrm{~m}^{2}$ e valor de venda no lançamento de $R \$ 450.000,00$, ambos no bairro do Caçari (IBAM,2006, p. 1-32). 


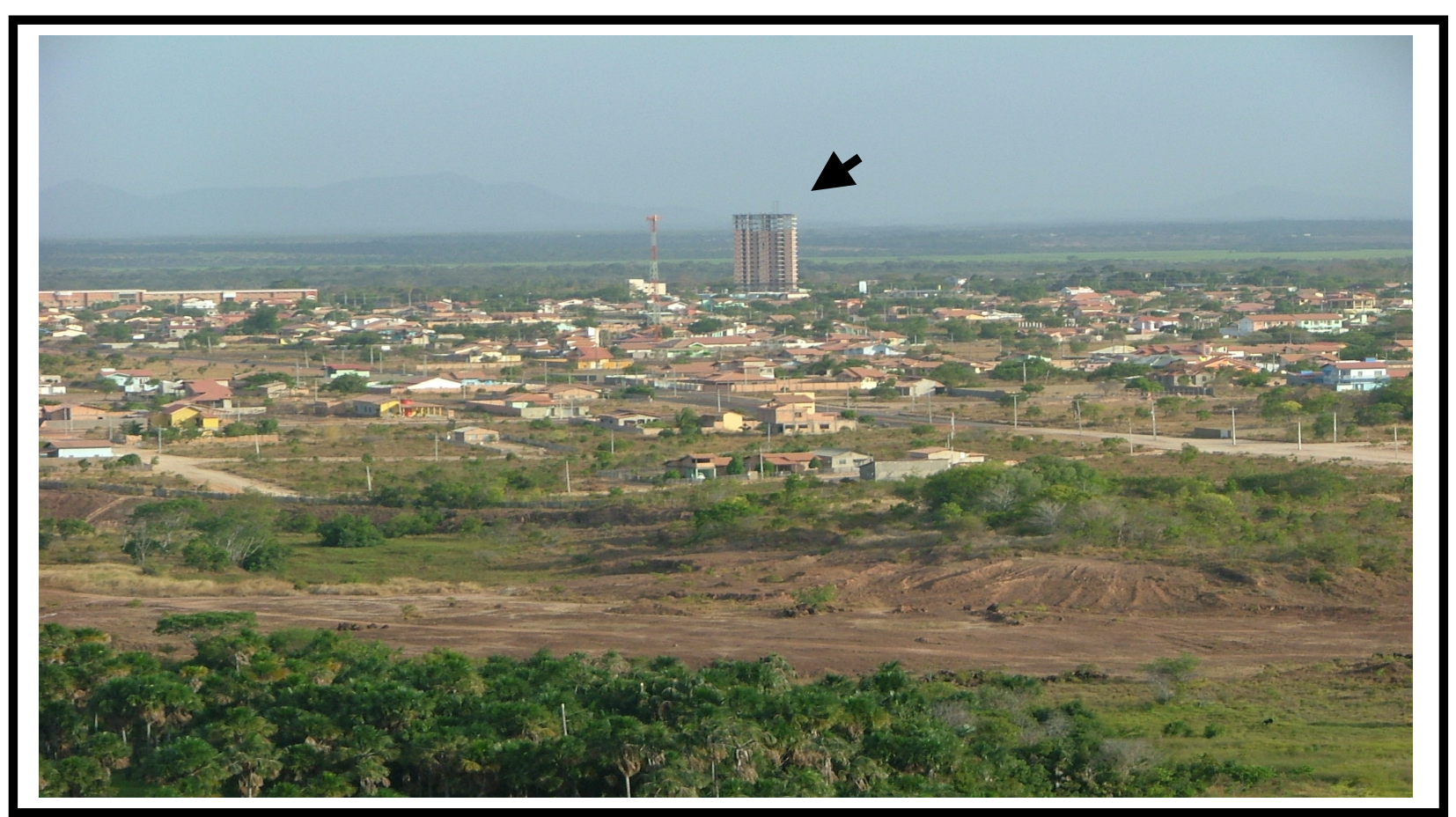

Figura 73: Edifício Residencial Varandas do Rio Branco (Primeiro edifício de Boa Vista) Legenda: $\triangle$ Edifício residencial

Foto: Acervo de Roberto Caleffi \UFRR

No contexto de atuação das empresas imobiliária, observa-se que a implantação de loteamentos e condomínios horizontais na cidade de Boa Vista tem como pano de fundo a busca do aumento do preço do solo urbano. Nesta dinâmica, o município e o próprio estado agem interferindo no mercado imobiliário, valorizando preços do solo urbano em determinadas áreas da cidade, com ações normativas que legitimam as práticas especulativas do capital imobiliário, privilegiando apenas uma parcela da sociedade.

Baseado nisso, também o capital imobiliário procura ter acesso a terra enquanto os preços não estão elevados, assim, após os investimentos em melhorias internas e externas, públicas ou privadas, há uma valorização da área antes de sua comercialização. Interessa ainda ao capital imobiliário a contínua criação de novos espaços, depreciando umas áreas e criando outras, favorecendo-se principalmente dos espaços urbanos que recebam investimentos públicos, mesmo ainda não recuperados, ou de áreas com planejamentos de investimentos futuros. 
A dinâmica atual da cidade de Boa Vista em relação à questão ambiental, na concepção de Agostinho (2001), tende para uma realidade preocupante em função da ausência de políticas públicas consistentes voltadas para o controle dos assentamentos urbanos em Área de Proteção Permanentes - APP's.

Para o geógrafo Agostinho (2001)

A mancha urbana após ter ocupado integralmente o polígono Rio Branco, Rio Cauamé, Igarapé Caranã e Igarapé Pricumã na década de 80 , agora se dirige com impressionante velocidade na direção Sudoeste e Oeste. Dando uma idéia da explosão urbana da cidade de Boa Vista, bem como dos seus principais vetores de crescimento atual [...]. Este inchamento urbano gera uma série de difíceis problemas para a administração pública estadual e municipal, como os de caráter ambiental, através dos impactos produzidos por atividades construtivas, demanda energética, uso de recursos hídricos e disposição inadequada de esgotos e lixo doméstico...

Outro aspecto a considerar são as constantes ocupações irregulares que vêm ocorrendo na cidade em áreas próximas a APP's. Um exemplo recente foi à ocupação do denominado conjunto São Bento (Figura 74). Hoje, titulada como ZEIS.

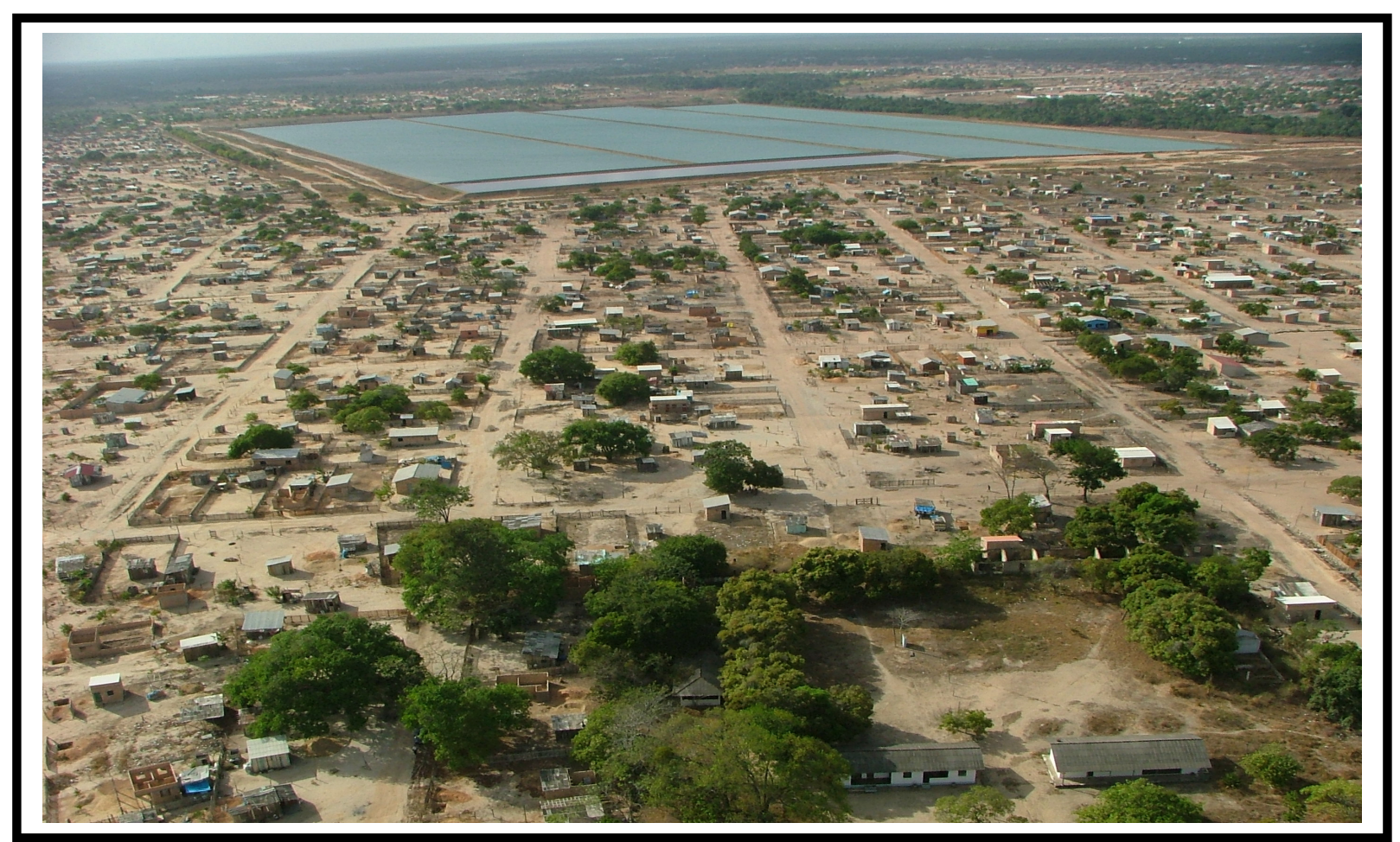

Figura 74: Assentamento Urbano São Bento (ao fundo a lagoa de estabilização e igarapé grande)

Foto: Acervo de Roberto CallefilUFRR - 2008 
Cabe informar, que esse processo de ocupação de áreas periféricas não é exclusivo da cidade de Boa Vista. Segundo o IBAM (2006, p. 32)

No Brasil a ocupação de áreas periféricas, especialmente por populações de baixa renda, caracteriza-se pelo surgimento de áreas informais, desordenadamente ocupadas, sem condições mínimas de habitabilidade, com demanda crescente por infra-estrutura e serviços urbanos.

Também o uso inadequado de áreas públicas de interesse ambiental em Boa Vista não se restringe apenas aos assentamentos irregulares, mas atinge bairros considerados nobres, exposto no item 3.5, onde ocorrem abusos de incorporação de parcelas de áreas públicas aos imóveis particulares.

Boa Vista, hoje, apresenta-se em acelerado crescimento urbano englobando sempre novas áreas e extensões fragmentadas. Esse processo de reprodução do espaço urbano também nos coloca diante de novas formas que ganham novos conteúdos. Como exemplo, a Área de Livre Comércio - ALC, e Zona de Processamento e Exportação - ZPE, que foi implantada no município em 2008.

$\mathrm{Na}$ avaliação do diretor de Operações da Empresa Municipal de Habitação e Urbanismo (EMHUR), Afonso Mesquita, com a implantação da ALC e ZPE, o crescimento da cidade será direcionado para a Zona Norte e Oeste, como previsto Plano Diretor de Boa Vista. Para tanto, a prefeitura reservou uma área de 150 hectares em local privilegiado, às margens da $\mathrm{Br} 174$, na saída do Contorno Oeste. É cabível informar, ainda, que $90 \%$ da área urbana de Boa Vista será abrangida, atendendo $100 \%$ dos bairros (JORNAL FOLHA DE BOA VISTA, 17-04-2008).

Conforme o prefeito Iradilson Sampaio, com a criação da ALC e ZPE, será necessário melhora o sistema de transporte na cidade. Assim, a prefeitura, em parceria com o Governo Federal, estar construindo o contorno Oeste para facilitar o acesso à cidade (Figura 75) (JORNAL FOLHA DE BOA VISTA, 05-03-2008). Bem como, reordenando as estratégias de planejamento urbano com o objetivo de conter o desordenamento da cidade. 


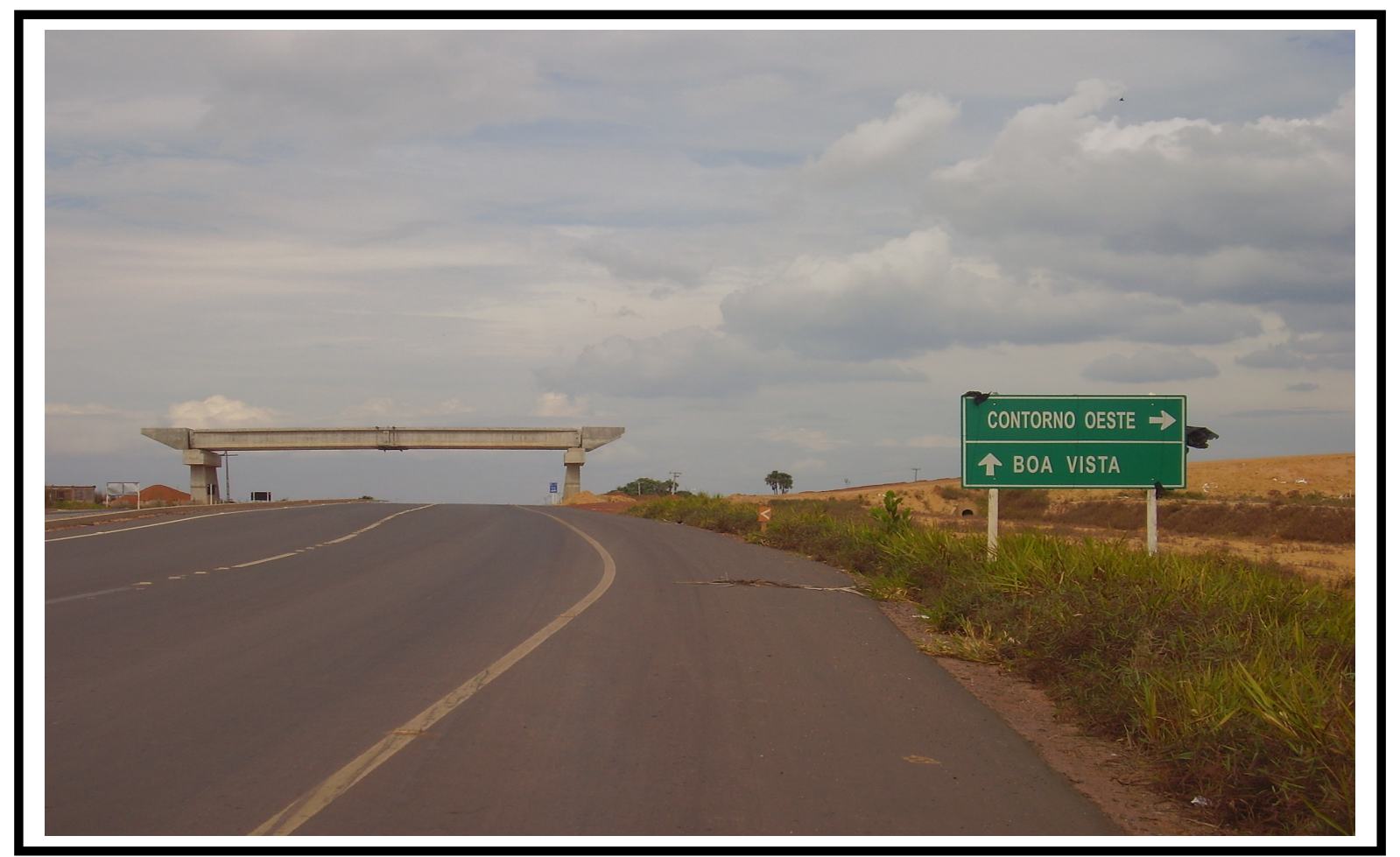

Figura 75: Contorno Oeste

Foto: Acervo de Antonio Tolrino de Rezende Veras - 2008

Verifica-se, no entanto, que a questão de transporte na cidade é séria, isto é, não será o contorno Oeste que irá resolver o problema, uma vez que Boa Vista:

Concentra $95 \%$ da frota dos veículos do estado, com aproximadamente 80 mil veículos, sendo um para cada 2,91 habitantes, Boa Vista está bem próxima da realidade de São Paulo quando o assunto é número de veículos por habitantes. Com isso, Boa Vista começa a entrar na lista das cidades onde o trânsito é caótico [...].

$\mathrm{Na}$ Capital roraimense os motoristas não ficam horas em engarrafamentos, mas sinais de estrangulamento no trânsito são observados em alguns pontos da cidade nos horários de pico, como por exemplo, ao meio-dia na rotatória entre a Avenida Glaycon de Paiva e a Terêncio Lima [...].

De acordo com o secretário municipal de Segurança Urbana e Trânsito, Coronel Antônio de Matos Neto, algumas ações já foram realizadas para melhorar o trânsito em Boa Vista. Uma delas é a obra na saída norte da cidade, na Avenida Carlos Pereira de Melo, onde foram feitas calçadas, reformulação da geometria das rotatórias, canteiro central na Avenida João Alencar, drenagem de 1.200 metros, recapeamento do asfalto, sarjeta e meio-fio. No local também foram colocadas sinalizações vertical e horizontal (280 placas e $11 \mathrm{~km}$ de pintura de solo), num investimento total de $R \$ 1,9$ milhão (JORNAL FOLHA DE BOA VISTA DE 26-05-2008). 
Esse acréscimo de veículos automotores e a fluidez provocada por eles devem-se, principalmente, a facilidade de crédito para aquisição de veículos, ao processo migratório, à reforma administrativa estadual e municipal no final do século $\mathrm{XX}$, à concentração das atividades de comércio e serviços na cidade, entre outros fatores de ordem social, econômica e político-administrativo ao longo de sua produção espacial, como exposta ao longo da pesquisa.

Isso confere a Boa Vista ser considerada como uma cidade primaz em relação a outras cidades do Estado de Roraima. $\mathrm{Na}$ análise do professor Francisco Capuano Scarlato (2006), ${ }^{29}$ sua superioridade se deve a sua estrutura urbana, e à disponibilidade de equipamentos e serviços em seu espaço que the condiciona a uma condição que poderíamos denominar de "metrópole", na realidade geográfica em que está inserida.

Ainda, segundo o professor Scarlato (2006) as transformações no espaço urbano de Boa Vista foram intensas. Com isso, surgiram novos bairros e as relações sócioespaciais redefiniram novas formas e funções para os equipamentos e serviços urbanos em diferentes frações da cidade. Desta maneira, a cidade sofreu mudanças significativas no seu traçado urbano, bem como na realidade cotidiana das pessoas que passaram a incorporar novas centralidades.

\footnotetext{
${ }^{29}$ Em viagem de campo realizada entre os dias 09 e 12 de agosto de 2006 pelo estado de Roraima e na fronteira com a Venezuela, quando se observou a estrutura urbana roraimense.
} 


\section{Considerações Finais}

Nesta pesquisa, procuramos mostra como se deu o processo de produção do espaço urbano de Boa Vista, capital do Estado de Roraima. Para análise, fizemos uma leitura dos sistemas de objetos e sistemas de ações incorporados pelo Governo Colonial, pelos militares, colonizadores, fazendeiros, ação garimpeira, religiosos e o Estado Nacional no sentido de dotá-la de equipamento e serviços com o objetivo de ocupar, proteger e desenvolver as fronteiras da região Norte do Brasil setentrional.

Desta maneira, consideramos relevante a discussão sobre a produção do espaço em virtude do crescimento sócioespacial desta cidade ao longo de sua formação histórica, evidenciados nos processos e formas pré-existentes na atual configuração sócioespacial.

Observamos, a princípio, que o processo de produção do espaço urbano de Boa Vista estar diretamente ligado com a ação da Coroa Portuguesa em defender suas possessões de terras na Amazônia da invasão dos espanhóis, ingleses e franceses no período colonial. Para tanto, mandou construir vários fortes em áreas estratégicas às margens dos principais rios amazônicos.

Assim, em 1775, foi construído o Forte São Joaquim na confluência dos rios Uraricoera e Tacutu, desta confluência, nasce o rio Branco principal rio do vale do rio Branco.

A partir da construção do Forte, no seu entorno, surgem as aldeias e fazendas de gado, que funcionavam inicialmente como alicerce no processo de ocupação e proteção da região, em que os religiosos eram peças fundamentais, pois catequizavam os índios para o trabalho servil.

Depois dos militares e religiosos vieram os colonizadores, atraídos pelas promessas de riqueza feitas pela Coroa para que se instalassem no alto rio Branco, ocupando definitivamente a região. $O$ objetivo era que eles implantassem fazendas e desenvolvem a pecuária para suprir de carne o contingente militar do Forte e 0 mercado da região amazônica.

Em 1830, foi instalada a fazenda Boa Vista na margem direita do rio Branco, distando aproximadamente $32 \mathrm{~km}$ do Forte São Joaquim. A fazenda foi crescendo e atraindo para os arredores a população indígena, a qual passou a fazer parte da população, atuando em trabalhos braçais. Posteriormente, a fazenda passou a ser 0 
principal povoado do alto rio Branco. Nasce aqui o núcleo embrionário da atual cidade de Boa Vista.

Percebemos que, com a conquista do Rio Branco, a instalação do Forte de São Joaquim, assim como dos aldeamentos, das fazendas nacionais, da Freguesia, e a criação do Município de Boa Vista do Rio Branco, nos séculos XVIII e XIX, foram ações e intencionalidade que objetivavam ocupar e desenvolver o território e garantir sua defesa e posse. Boa Vista, por muito tempo, foi a única cidade daquela área, uma vez que o surgimento das demais cidades é recente.

De acordo com informações do Jornal Folha de Boa Vista (09-07-2008), a formação do patrimônio urbano de Boa deu-se no dia 30 de Janeiro de 1899, quando por meio de um contrato de compra e venda, o então Município de Boa Vista do Rio Branco adquiriu do Estado do Amazonas sua légua patrimonial. A sede possuía um perímetro de $28.154 \mathrm{~m}^{2}$, limitava-se ao Norte com o rio Caumé, a Leste com o rio Branco, a Oeste com os rios Caranã e Pricumã.

Vale lembrar que até 1943, quando foi criado o Território Federa do Rio Branco o Município de Boa Vista do Rio Branco estava sob a jurisdição do Estado do Amazonas.

Ao analisar a produção do espaço urbano de Boa Vista, levando em consideração a relação espaço-tempo, dos acontecimentos (história e fatos históricos), das apropriações do solo urbano, das ações e intencionalidades dos agentes promotores do espaço urbano; remetemo-nos a uma complexidade territorial em que a produção do espaço torna-se fragmentada e articulada, o que denota que esse espaço urbano é um reflexo de sua sociedade, isto é, são os agentes sociais que fazem e refazem a cidade. Esses agentes podem ser os proprietários dos meios de produção, os proprietários fundiários, os promotores imobiliários, o Estado e os grupos sociais excluídos.

Já no ano de 1943, algumas ações políticas do Governo Central reforçam a necessidade de ocupar e proteger a região. Entre essas ações destaca-se a criação do Território Federal do Rio Branco pelo Presidente Getúlio Vargas a partir do Município de Boa Vista. Em 1944, a cidade de Boa Vista foi declarada a capital do novo Território, ato acompanhado da implantação do Plano Urbanístico da cidade pela a firma Riobras do engenheiro civil Darcy Aleixo Derenusson, sob as ordens do primeiro Governador do Território Capitão Êne Garcez dos Reis. 
A partir da implantação do Plano Urbanístico, a expansão territorial urbana de Boa Vista propiciou a diferenciação do espaço urbano, na medida em que criou um acesso seletivo e desigual das pessoas à cidade. Pois o Plano não contemplava toda a cidade, apenas a área do núcleo embrionário e a área destinada à implantação do plano, que vai do atual bairro Centro a Rua Major Williams e Terêncio Lima (continuação da Rua Major Williams).

Outra questão é que o Plano Urbanístico passou a incorporar novos ritmos de organização espacial devido ao caráter concentrador e pelo fato dos arranjos espaciais que definiam a cidade na época estarem ligados a ações políticas isoladas, que, por sua vez, eram seletivas e acentuavam as desigualdades, criando diferenciações sócioespaciais intraurbanas e a formação de territórios precários, que até hoje são presenciados.

Desta forma e apoiados em Harvey (1980, Apud NUNES, 2007, p. 157), em Boa Vista, os processos sociais estavam relacionados às formas espaciais, pelo fato de que as contradições sociais do desenvolvimento econômico em conjunto com a produção do espaço urbano - enquanto expressão da divisão territorial do trabalho e aos instrumentos urbanísticos resultaram em diferenciações sócioespaciais que definiram o lugar de vivência de cada um.

No período da implantação do Plano Urbanístico, o novo Território era governado por civis e militares indicados pelo o Presidente da República, sendo que o prefeito era indicado pelo o governador e não tinha poder de decisão nas ações político-administrativa locais. Posteriormente, após o golpe militar de 1964 o Território Federal de Roraima passou a ser administrado por Oficiais da Força Aérea Brasileira - Aeronáutica, que pendurou até 1988, quando o então Território Federal de Roraima foi transformado em Estado.

Muitos foram os governadores que passaram pelo Território, ao mesmo tempo, foram poucos os que contribuíram para o seu desenvolvimento do mesmo. Assim, a produção do espaço urbano de Boa Vista foi marcada pela ação concentradora do poder na mão do governador e no interesse das famílias influentes da época, que eram as principais detentoras das terras urbanas da cidade.

Nessa trama, não podemos deixar de enfatizar que o Plano Urbanístico foi um marco na dinâmica de produção do espaço urbano de Boa Vista. Com ele veio às primeiras infra-estruturas urbanas planejadas, com destaque para o saneamento básico da cidade, a construção de escolas rurais, matadouro público, entre outras.. 
Vale acrescentar que esse Plano Urbanístico, em especial, o traçado urbano da cidade - radial concêntrico foi aceito de forma unânime pela a população da cidade. Também contribuiu direta e indiretamente para a geração de renda e emprego da população da cidade. Apesar da maioria da mão-de-obra utilizada para a execução das obras terem vindo de outros estados do país.

O referido traçado urbano foi inspirado na cidade de Belo Horizonte, que apresenta ruas largas e as principias avenidas convergindo para o Centro, formando um leque urbano.

Outro aspecto a considerar em relação ao Plano Urbanístico diz respeito ao autor do projeto, o engenheiro civil Darcy Aleixo Derenusson, e à necessidade de se preservar o modelo radial concêntrico como patrimônio histórico. Na cidade, é desconhecida qualquer escola, rua, avenida entre outros equipamentos urbanos, que tenha seu nome como lembrança "In memória" pelo serviço prestado ao então Território Federal de Roraima, hoje Estado. Este seria o momento ideal para propor a criação de um busto do engenheiro, já falecido, no dia 17 de maio de 2002, e sua afixação na Praça do Centro Cívico, bem como o tombamento do respectivo modelo radial concêntrico junto ao Instituto do Patrimônio Histórico e Artístico Nacional IPHAM com representação na cidade de Boa Vista.

O tombamento justifica-se, em função das ações e intencionalidades dos agentes promotores do espaço urbano que vem alterando substancialmente e de forma invisível e conivente com os gestores públicos o traçado original da cidade criando novas funcionalidades para a Praça Central. Assim, faríamos jus a esse magnífico e herói engenheiro civil Darcy Aleixo Derenusson.

Apesar de Boa Vista estar localizada numa área estratégica em relação aos países vizinhos - Venezuela e a Guiana -, ficou isolada por muito tempo do restante do país, pois a conexão que a cidade possuía com outras cidades até a década de 70 , quando foi construída a BR 174, era realizada por via fluvial através do rio Branco. Além disso, segundo Silva (2007, p. 300), o acesso fluvial só era possível entre Manaus e Caracaraí, o que dificultava a interligação entre Boa Vista - Manaus. Nos períodos de baixas vazões do rio Branco, era totalmente interrompido, o que impedia a navegação até mesmo a Caracaraí, criando-se um total isolamento da ligação fluvial. Também por via aérea, que era utilizada, em sua maioria, para o transporte de cargas militares e por autoridades políticas. Desta forma, não se tinha um transporte aéreo eficaz, como até hoje, ainda, não se tem no Estado. 
Percebemos que a produção do espaço urbano de Boa Vista constituiu-se num processo em que a ação do Estado Nacional foi ausente, negando a sua importância e existência no cenário nacional e regional frente as suas potencialidades locais, bem como sua posição estratégica e geopolítica em relação aos países vizinhos, Venezuela e Guiana.

No entanto e apoiados em Silva (2007, p. 305) apesar da cidade de Boa Vista, ou seja, o Estado de Roraima possuir pouca representatividade no cenário regional amazônico e nacional, acredita-se que essa situação pode ser alterada, tendo em vista "a sua privilegiada situação geográfica, que hoje é interpretada por outro viés, isto é, se antes foi um determinante para um crescimento pequeno, apresenta-se na atualidade como um impulsionador". Como argumenta SCARLATO $(2006)^{30}$, "Roraima vai despertar, transformando-se na porta de entrada para o norte da América do Sul e Caribe, integrando essas regiões ao Brasil e conseqüentemente, ao MERCOSUL (Mercado Comum do Cone Sul)." Onde, a capital Boa Vista será o centro polarizador das ações, pois é na cidade que se concentra os principais equipamentos e serviços urbanos do Estado de Roraima (instituições financeiras, bancos, universidades, clinicas especializadas, hospitais, hotéis entre outros).

Comungando com Silva (2007) e Scarlato (2006), o geógrafo Agostinho (2001, p. 1), reitera que o "Estado de Roraima é possuidor de uma invejável localização geográfica e geopolítica, além de um riquíssimo potencial de recursos naturais."

Em 1988, quando o Território Federal de Roraima é transformado em Estado, a cidade de Boa Vista passar a ter um fôlego maior nas ações voltadas para o desenvolvimento urbano, pois adquiriu autonomia político-administrativa em relação ao Estado, passando a receber o Fundo de Participação Municipal - FPM, o Imposto Território Urbano - IPT, entre outros impostos tributários municipais.

Nessa mudança, o prefeito passa a ser eleito pelo povo. É válido sublinhar que, do período de criação do Estado até hoje, o município de Boa Vista teve 4 (quatro) prefeitos. Sendo que o atual prefeito, Iradilson Sampaio, assumiu o cargo de prefeito em 2006, em função do afastamento da prefeita Teresa Jucá para concorrer às eleições para o Senado Federal.

\footnotetext{
${ }^{30}$ Trabalho de Campo em agosto de 2006.
} 
No que concerne a atuação desses gestores, verificamos que as políticas urbanas adotadas foram diferenciadas no espaço intra-urbano da cidade. Na sua maioria, as ações urbanas estão direcionadas para as áreas já urbanizadas, como é caso do bairro Paraviana, São Pedro, Centro, São Francisco, Mecejana, Aparecida entre outros. Diferentemente dos bairros periférico, como Santa Teresa, Jardim das Copaíbas e Operário, que ficam a mercê da boa vontade dos gestores.

Com isso, a cidade se transforma em diversas formas: setores urbanos se especializam, vias de comunicações tornam-se mais racionais, criam-se novos órgãos administrativos, e modificam-se as funções do lugar fazendo com que as classes médias e operárias passem a alojar-se no subúrbio, favelas ou bairros afastados; enquanto que as classes altas têm o privilégio de escolha de espaço; e, sobretudo, a cidade deixa de ser uma entidade espacial bem delimitada.

Podemos observar que a cidade, enquanto construção humana, produto social, trabalho materializado, apresenta diferente formas de ocupação. O modo de ocupação de determinado lugar dá-se a partir da necessidade de realização de determinada ação, seja de produzir, consumir, comercializar, habitar ou viver.

De acordo com Spósito (2004, p. 12):

\begin{abstract}
Para entender a cidade, não basta apenas observá-la ou viver nela. É preciso verificar a sua dinâmica, a sua geografia e a sua história. Ou seja, é preciso observar a movimentação das pessoas em suas ruas, as relações comerciais, onde estão localizados os estabelecimentos industriais, onde moram e estudam seus habitantes, etc. $E$ também aceitar o fato de que a cidade na qual vivemos, salvo exceções nas regiões mais novas, não aparece no momento em que nascemos, mas já tinha uma história e certamente continuará a existir quando morremos, porque seja ela pequena ou grande, localizada no Brasil ou na Europa, originada neste séculos ou no século XVII, permanece através de suas formas e suas contradições.
\end{abstract}

Sendo assim, a cidade e seus espaços são produtos de processos históricos, nos quais tudo se interage através da produtividade desses espaços. Esses espaços se transformam à medida que novas necessidades sócioespaciais surgem, como no caso da Avenida Ville Roy, Jaime Brasil, Mario Homem de Melo, Princesa Isabel, Ataíde Teive, Guianas entre outras, que possuem aéreas comerciais, residências, acesso a bens e serviços a população local, dos bairros adjacentes e mais afastados, ocorrendo assim uma mudança na estrutura econômica e espacial das avenidas de Boa Vista. 
Verificamos também que muitos movimentos de ocupações irregulares acontecem em toda cidade, principalmente, em áreas pouco valorizadas e desprovidas de infra-estruturar, estas ocupações irregulares foram responsáveis pela apropriação irregular de grandes glebas ambientalmente frágeis e pelas conseqüentes obras de aterro nestas áreas do município. Desta maneira, o espaço físico-territorial, passa a ser um dos fatores determinantes da expansão urbana, principalmente por delimitar a área de ocupação e ação dos demais agentes formadores deste espaço.

Outro aspecto a considerar diz respeito à energia elétrica, pois, desde a década de 1990, a cidade é abastecida por energia proveniente da hidrelétrica de Guri na Venezuela. Antes era abastecida por termoelétricas, as quais não favoreciam o desenvolvimento de Boa Vista, em especial no setor secundário e terciário.

Com a energia, não só Boa Vista se beneficiou, mais todo o Estado de Roraima. Na verdade, foi um dos fatores determinantes para a inserção de novos investimentos na região. A cidade passou a ser a sede administrativa desses investimentos, como foi o caso do agribusiness nacional e internacional sob o impulso da soja.

Nessa conjuntura, a modernidade em Boa Vista ultrapassou o tempo lento para incorpora-se ao tempo rápido por meio de novas tecnologias que fazem de Boa Vista uma cidade em plena ascensão no cenário nacional e internacional em virtude de sua posição estratégica e geopolítica. A essa modernidade associam-se diversas franquias de empresas de telefonia móvel e fixa, como a CLARO, TIM, VIVO e OI, de empresas automotivas FIAT, FORD, PEUGEOT, TOYOTA, HONDA E CHEVROLET, de restaurante BOB's, de perfumaria BOTICARIO, entre outras. Todas essas facilitam uma conexão rápida com outros estados brasileiros e países e incorporam ao mercado da cidade novos processos de produção sócioespacial.

Nesse tempo rápido, a cidade concentra todas as retransmissoras de televisão, as principais emissoras de rádios nas faixas AM e FM e os dois jornais de circulação diária no estado.

Associado também a essa modernidade, observamos 0 aparelhamento (informatização) do serviço público e privado, com o objetivo de facilitar o acesso aos equipamentos e serviços por parte da população, com destaque para as universidades, hospitais, hotéis, aeroporto, empresas imobiliárias e bancos. 
Da mesma forma, segundo Silva (2007, p. 307),

As atividades culturais e de lazer que se concentram na capital, tais como cinemas que exibem filmes lançados nacionalmente, teatros com peças locais e algumas regionais e nacionais, bibliotecas, salas para conferências e shows, entre outros espaços para eventos, colaboram para essa modernidade.

É percebido apropriação de áreas pelo poder público para construção de centros de artesanatos, de praças, de parques, de creches e escolas entre outros equipamentos urbanos, que favorecem uma qualidade de vida melhor para uma parcela da população. Pois, essas modernidades e construções não chegam elou atendem a população da cidade como um todo.

Destacamos também que as ações ocorridas no campo estão diretamente ligadas com a dinâmica de produção do espaço urbano de Boa Vista, uma vez que é em Boa Vista que estão concentradas os comércios especializados no ramo agropecuário, as feiras que reúnem os diferentes produtores rurais e suas produções, os bancos de financiamentos e as principais instituições públicas e privadas que dão suporte técnico aos produtores rurais. Assim como é o lugar de moradia dos proprietários de fazendas e de grande parte dos operários que se ocupam dessa atividade.

Desta maneira, segundo Santos (2005, Apud SILVA 2007, p. 308)

\begin{abstract}
À proporção que o campo se moderniza, requerendo máquinas, implementos, componentes, insumos materiais e intelectuais indispensáveis à produção, ao crédito, à administração pública e privada, o mecanismo territorial da oferta e da demanda de bens e serviços tende a ser substancialmente diferente da fase precedente. Antes, o consumo gerado no campo, nas localidades propriamente rurais e, mesmo, nas cidades, era, sobretudo, um consumo consuntivo, tanto mais expressivo quando maiores os excedentes disponíveis, sendo função da importância dos rendimentos e salários, e, pelo contrário, tanto menos expressivo quanto maior a taxa de exploração, mais extensas as formas pré-capitalistas, mais significativo o coeficiente de auto-subsistência. Com a modernização agrícola, o consumo produtivo tende a se expandir e a representar uma parcela importante das trocas entre os lugares da produção agrícola e as localidades urbanas.
\end{abstract}

Nessas novas condições, a produção do espaço urbano de Boa Vista processa-se em função da centralidade que a cidade possui em relação aos bens e serviços especializados no setor agrícola. 
No tocante ao Plano Diretor da Cidade, é importante que haja uma fiscalização das ações do gestor público municipal por parte das autoridades competentes, em particular dos vereadores, bem como da sociedade civil, para que as Leis que regem o Plano Diretor sejam cumpridas. Isso iria impedir que as constantes ocupações irregulares fossem contidas, que o sistema de saneamento básico ficasse concentrado em áreas já urbanizadas, que o sistema de transporte coletivo fosse caótico, que o espaço urbano destinado a implantação da ALC e ZPE sejam ordenados entre outros.

Verificamos, portanto, que o processo de produção do espaço urbano de Boa Vista estar vinculado a sua formação histórica e as ações políticas, econômicas e sociais postas por diferentes agentes produtores do urbano - proprietários dos meios de produção, proprietários fundiários, promotores imobiliários, Estado e grupos sociais excluídos entre outros - definindo ações, interesses e correlação de forças configuradas espacialmente. E que resultou numa diferenciação espacial interna na cidade, proporcionando uma acumulação desigual de tempos em um só espaço. 


\section{REFERÊNCIAS BIBLIOGRÁFICAS}

ABREU, Mauricio de Almeida. A evolução urbana do rio de Janeiro. $2^{a}$ Ed. Rio de Janeiro: IPLANRIOIZAHAR, 1998.

AGOSTINHO, Jaime de. Subsídios à discussão de um plano de desenvolvimento sustentável para o estado de Roraima. São Paulo: FFLCH, USP, 2001. (Tese de doutorado).

ANDRADE, Liza Maria de. O conceito de cidade - jardim: uma adaptação para as cidades sustentáveis. Arquitextos\042.01. Endereço Eletrônico: www.vitruvius.com.br.

ANDRADE, Manuel Correia de. A questão do território no Brasil. 2 ed. São Paulo: Hucitec,2004.

ANDRADE, Manuel Correia de \& ANDRADE, Sandra Maria Correia de. A Federação BrasileiralUma análise Geopolítica e Geo-espacial. 2 ed. São Paulo: Contexto.2003.

ANDRADE, Manuel Correia de. Espaço, polarização e desenvolvimento: uma introdução à economia regional. 5 ed. São Paulo:Atlas, 1987.

ANUÁRIO DO RIO BRANCO, ORDEM DE SÃO BENTO. Rio de Janeiro. Seção de documentos do arquivo da OSB. Rio de Janeiro. Pasta no 4.

ARRAIS, Tadeu Pereira Alencar. Goiânia: As imagens da cidade e a produção do urbano In CAVALCANTI, Lana de Souza et al (org.). Geografia da cidade. Goiânia. Editora: Alternativa. 2001.

A. S. JUNIOR, Tércio. Roraima o Brasil do Hemisfério Norte: Diagnostico cientifico e tecnológico para o desenvolvimento. Fundação do meio ambiente e tecnologia de Roraima. Boa Vista, 1993.

BAHIANA, Luís Cavalcanti. O Norte na organização regional do Brasil. In: Geografia do Brasil. Rio de Janeiro: Instituto Brasileiro de Geografia e Estatística., v. 3, 1991. p. 15-23. 
BARBOSA, Reinaldo Imbrósio. Ocupação Humana em Roraima. I. Do Histórico Colonial ao Início do Assentamento Dirigido. Boletim do Museu Paraense Emilio Goeldi, 9 (1): 123-144. Belém, 1993-1.

BARROS, Nilson Cortez Crocia de. Paisagens e Tempo na Amazônia Setentrional: estudo de ocupação pioneira na América do Sul. Editora Universitária - UFPE. 1995.

BEAUJEU GARNIER. Jacqueline. Geografia Urbana. 2a Ed. Tradução: Raquel Soares de Brito. Edição da Fundação Calouste Gulbenkian. 1997.

BECKER, B. K. Amazônia. São Paulo: Ática, 1998. 6 ed. Série Princípios.

BECKER, B. K. Amazônia. São Paulo: Ática, 1990. Série Princípios.

BONATTO, Fábio. Transformações na paisagem natural de Boa Vista-RR: Um diagnóstico ambiental por geoprocessamento. Rio de Janeiro.2002.(Dissertação de Mestrado-UFRJ).

BONDUKI, Nabil. O Plano Diretor Estratégico de São Paulo In Planos Diretores Municipais: Novos Conceitos de Planejamento Territoriais (Org.) Bueno, Laura Machado de Melo et al. São Paulo. Annablume, 2007.

BRAGA, Olavo Viana. Momentos da história de Roraima. Editora: Silva. Manaus. 2002.

BRASIL, Amazonas. Roraima: Ligeiras anotações sobre a história política e econômica, a partir do século XVII e algumas informações geográficas. Boa Vista Roraima. 2006.

BRESCIANI, M.S. Permanência e ruptura no estudo das cidades. In: FILGUEIRAS GOMES, M.A.; FERNANDES A. (Org.) Cidades \& História: Modernização das cidades brasileiras nos séculos XIX e XX. Salvados, 1992. Dissertação (Mestrado em Arquitetura e Urbanismo) - ANPUR, Universidade Federal da Bahia. 
CAMPOS FILHO, Cândido Malta. Cidades Brasileiras: seu controle ou o caos: o que os cidadãos devem fazer para a humanização das cidades brasileiras no Brasil. 4ed. São Paulo:Studio Nobel, 2001.

CAMURÇA NETO. Roraima: o despertar Boa Vista. 1996. (Monografia).

CARDOSO. Fernando Henrique. \& MULLER. Geraldo. AMAZÔNIA: Expansão do Capitalismo. $2^{\underline{a}}$ ed. São Paulo: Editora brasiliense. 1978.

CARLOS, Ana Fani Alessandri. A cidade. 8.ed. 1a reimpressão. São Paulo: Contexto. 2007.

CARLOS, Ana Fani Carlos. São Paulo: Dinâmica urbana e metropolização In Revista Território. Rio de Janeiro. Ano VII. № 11, 12 e 13 - setlout. 2003.

CARLOS, Ana Fani A. A (re) produção do espaço urbano. São Paulo: EDUSP, 1994.

CARLOS, Ana Fani Alessandri. A cidade. São Paulo: Contexto, 1992.

CARRION, Fernando. O Desenvolvimento Urbano de Quito Entre Suas Crises Urbanas Mais Recentes. In Revista de Estudos Regionais e Urbanos. Ano V - 1985 - № 16 Distribuição : Livraria Nobel S.A - São Paulo.

CASTELLS, Manuel. Problemas de Investigação em Sociologia Urbana. Tradução: Lemos de Azevedo. 2ª edição. Lisboa: Editora Presença, LDA. 1979.

CASTELLS, Manuel. La question urbana. 2ª Ed. México:Siglo Veintiuno,1976.

CAVALCANTI, José Maria dos Santos Araújo. Planejamento Regional: Recuperação e desenvolvimento do Vale do Rio BrancolAproveitamento e valorização econômica da região banhada pelos rio Branco, Uraricuera, Tacutu e Mucajaí. A encosta Guianense. 2. ed. Rio de Janeiro: Divisão de Orçamento e Organização \Departamento Administrativo do Serviço Público. 1949.

CAVALCANTI, José Maria dos Santos Araújo. Recuperação e desenvolvimento do Vale do Rio Branco. 2. ed. Rio de Janeiro: Jornal do Comércio, Rodrigues \& Cia, 1949. 
CAVALCANTI, José Maria dos Santos Araújo. Território do Rio Branco: Recuperação e desenvolvimento do Vale do Rio Branco. Rio de Janeiro: Divisão de Orçamento e Organização \Departamento de Administrativo do Serviço Público 1945.

CAVALCANTI, Lana de Souza. Uma geografia da cidade - elementos da produção do espaço urbano. In Geografia da Cidade. Goiânia: Editora Alternativa, 2001.

CENTRO PELO DIREITO À MORADIA CONTRA DESPEJOS - COHRE. CONFLITOS URBANO-AMBIENTAIS EM CAPITAIS AMAZÔNICAS: BOA VISTA, BELÉM, MACAPÁ E MANAUS. Impressão: Gráfica Calábria. Apoio: Embaixada da Holanda no Brasil. 2006.

CONSELHO FEDERAL DE ENGENHARIA, ARQUITETURA E AGRONOMIA CONFEA. Revista On Line: Publicado: $24 \backslash 09$ \2004. Endereço Eletrônico:

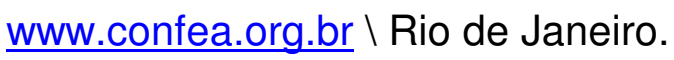

CORRÊA, Roberto Lobato. O espaço Geográfico: algumas considerações. In Novos Rumos da Geografia Brasileira. Milton Santos (Org). São Paulo: Hucitec, 1993. $3^{\text {a }}$ ed.

CORRÊA, Roberto Lobato. Região e Organização Espacial. São Paulo: Ática. 1990. $3^{\text {a }}$ ed.

CORRÊA, Roberto L. O espaço urbano. São Paulo: Ática, 1989.

costA, Clóvis Nova da. O Vale do Rio Branco: suas realidades e perspectiva.Departamento de Imprensa Oficial.Rio de Janeiro.1949.

COSTA, Francisco de Assis. Nem tudo no ouro reluz: considerações para uma economia política da garimpagem na fronteira amazônica. In: MATHIS, Armin; REHAAG, Regine (Org.). Conseqüências da garimpagem no âmbito social e ambiental na Amazônia. Belém: BUNTSTIFT/FASE/ KATALYZE, 1993. Anais... Belém: (S.I.), 1992. p. 10-35.

COULANGES, Denis Fustel de. La cittá antique. Florença. 1924. 
CHOAY, Françoise. O Urbanismo - utopias e realidades, uma antologia. $5^{\text {a }}$ edição, Editora Perspectiva SA, São Paulo, 1998.

D’ALMADA. Manoel da Gama Lobo. Descrição relativa ao rio Branco e seu território (1787) In anexo. COSTA, Clovis Nova da. O vale do rio Branco: suas realidades e perspectivas. Dept ${ }^{\circ}$. de imprensa oficial. Rio de Janeiro, 1949.

DINIZ, Alexandre M.A \& AMORIM FILHO, Oswaldo Bueno. Boa Vista, Roraima: Uma cidade média na fronteira setentrional do Brasil In Moura, Ana Maria S \& Sena Filho, Nelson de (Org.). Cidades: relações de poder e cultura. Goiânia - Ed. Vieira, 2005.

DONNE, Marcella Delle. Teorias sobre a cidade. Arte e Comunicação: Livraria Martins Fontes Editora Ltda. São Paulo. 1983.

EGGERATH, Pedro. O vale e os índios do Rio Branco. Rio de Janeiro: Tipografia Universal, 1924.

ENCICLOPÉDIA ITAÚ CULTURAL. Artes Visuais \Site: www.itaucultural.org.br. Atualizado em 30/10/2007. Pesquisado em 25104/2008.

FARAGE, Nádia. As muralhas do sertão: os povos indígenas no rio Branco e a colonização. Rio de Janeiro: Paz e Terra; ANPOCS, 1991.

FARRAR \& RINEHART, Inc. Ninety-two days the account of a tropical jorney through British Guiana and part of Brazil...By Evelyn Waugh. Publishers, New York, 1934.

FERREIRA, João Sette Whitaker Ferreira \& MOTISUKE, Daniela. A Efetivação da Implementação de Zonas Especiais de Interesse Social no Quadro Habitacional Brasileiro In Planos Diretores Municipais: Novos Conceitos de Planejamento Territoriais (Org.) Bueno, Laura Machado de Melo et al. São Paulo. Annablume, 2007.

FERRI, Patrícia. Achados ou perdidos a imigração indígena em Boa Vista. Goiânia: 1990. 
FONTE, Mariana Levy Piza; SANTORO, Paula \& CYMBALISTA, Renato. Estatuto da Cidade: Uma leitura sob a perspectiva da gestão social da valorização da terra In Planos Diretores Municipais: Novos Conceitos de Planejamento Territoriais (Org.) Bueno, Laura Machado de Melo et al. São Paulo. Annablume, 2007.

FREITAS, Aimberê. A História Política e Administrativa de Roraima de 1943 a 1985. Manaus: Editora Umberto Calderaro Ltda. 1993.

GEDDES,Patrick. Cidades em Evolução. Tradução: Maria José Ferreira de Castillho.Campinas, São Paulo: Papirus, 1994.

GODOY, Paulo. Uma Reflexão Sobre a Produção do Espaço. In Revista: Estudos Geográficos, Rio Claro, 2(1): 29 -42. Junho - 2004.

GUERRA, Antônio Teixeira Guerra. Estudos Geográficos do território do Rio Branco. IBGE.1957.

GUIDUGLI, Odeibler Santo. A geografia da população urbana: aspectos teóricos e o caso de Marília - SP. Vol 1 e 2 USP - 1979. 543 p.

GUIMARÃES. Alberto Prado. O Monge BÊneditino Dom Pedro Eggerath. Da Sociedade de Geografia de Lisboa e do Instituto Histórico e Geográfico de São Paulo. 1978.

HARVEY, David. A justiça social e a cidade. São Paulo: Hucitec, 1980. xiv, 291 p.

HOWARD, Ebênezer. Cidades-Jardins de Amanhã. Tradução: Marcos Aurélio Lagonegro.São Paulo-Hucitec.1996.

INSTITUTO BRASILEIRO DE ADMINISTRAÇÃO MUNICIPAL - IBAM. Anteprojeto de Lei de Uso e Ocupação do Solo Urbano de Boa VistalRR. 2006, p. 1-16.

INSTITUTO BRASILEIRO DE ADMINISTRAÇÃO MUNICIPAL - IBAM. Anteprojeto de Lei do Plano Diretor Estratégico de Boa VistalRR. 2006, p.1-35. 
INSTITUTO BRASILEIRO DE ADMINISTRAÇÃO MUNICIPAL - IBAM. Diagnóstico Municipal Integrado - Produto: 7. 2006, p. 1-22.

INSTITUTO BRASILEIRO DE ADMINISTRAÇÃO MUNICIPAL - IBAM. Diagnóstico Preliminar: Mobilidade Urbana. 2006, p. 1-42.

INSTITUTO BRASILEIRO DE ADMINISTRAÇÃO MUNICIPAL - IBAM. Relatório de Análise da Situação Habitacional de Boa Vista. 2006, p. 1-32.

INSTITUTO BRASILEIRO DE GEOGRAFIA E ESTATÍSITCA - IBGE - RR. Cidades. Boa Vista, 2004.

INSTITUTO BRASILEIRO DE GEOGRAFIA E ESTATíSTICA - IBGE. Atlas de Roraima. Rio de Janeiro: IBGE / Governo do Território Federal de Roraima, 1981.

INSTITUTO BRASILEIRO DE GEOGRAFIA E ESTATÍSITCA IBGE.Recenseamento Geral do Brasil ( $1^{\circ}$ de setembro de 1940). Série Regional Parte II - Amazonas. Censo Demográfico - População e Habitação. Censo econômico, agrícola, industrial, comércio e dos serviços. Rio de Janeiro: 1952.

INSTITUTO BRASILEIRO DE GEOGRAFIA E ESTATíSITCA - IBGE. Conselho Nacional de Estatística: Sinopse Estatística do Município de Boa Vista Território de Rio Branco. Rio de Janeiro. 1951.

JORNAL A GAZETA DE RORAIMA. Edição especial. Boa Vista \ano 101. Ano X. 09 de Julho de 1991.

JORNAL BOA VISTA. Edição de 14.02.1976.

JORNAL BOA VISTA. Edição de 26.08.1975.

JORNAL BOA VISTA. Edição de 18.07.1974.

JORNAL DA PREFEITURA. Ano 2. № 9|Boa Vista-RR.Março de 2006.

JORNAL FOLHA DE BOA VISTA. Edição de 28-05-2008.

JORNAL FOLHA DE BOA VISTA. Edição de 26-05-2008. 
JORNAL FOLHA DE BOA VISTA. Edição de 17-04-2008.

JORNAL FOLHA DE BOA VISTA. Suplemento especial - Boa Vista: 118 anos, em fatos e fotos. 09 julho 2008.

JORNAL FOLHA DE BOA VISTA. Edição de 05-03-2008.

LAURIANO, Sandra Elane de Souza. O setor comercial do espaço urbano de Boa Vista. Monografia de conclusão do Curso de Licenciatura Plena em Geografia. Universidade Federal de Roraima. 2005.

LIMONAD, Ester. Reflexões sobre o espaço, o urbano e a urbanização. GEOgraphia - Ano 1 - No 1 - 1999. Universidade Federal Fluminense.

LUCKMANN, Donato. História e Geografia do Município de Boa Vista. Série: Roraima Através dos Municípios. Vol.1. Apoio: Prefeitura Municipal de Boa Vista/Fundação de Educação, Ciências e Cultura de Roraima - FECEC.1989.

MACAGGI, Nenê. A Mulher do Garimpo (O romance do extremo sertão norte do Amazonas). Manaus: Composto e Impresso nas Oficinas Gráficas da Imprensa Oficial, 1976.

MAGALHÃES, Dorval de. Informações Históricas de Roraima. 1986. (Produção Independente).

MARINATO, Cristina Fiorin. Aterros em Vitória: Uma história para ser lembrada. Monografia apresentada à Universidade Federal do Espírito Santo, em cumprimento aos requisitos para obtenção da Graduação em Arquitetura e Urbanismo. 2000.

MARTINS, Aurineide Martins \& SALES, Maria Ivane. Resgate Histórico de Piranhas à Crateús. Fortaleza-Ceará. 1995. Produção independente.

MOREIRA, Ruy. Repensando a Geografia. In Novos Rumos da Geografia Brasileira. Milton Santos (Org). São Paulo: Hucitec, 1993. $3^{\underline{a}}$ ed. 
MOTA, Adeir Archanjos \& MENDES, Cesar Miranda. Artigo: Considerações sobre as estratégias e ações dos promotores imobiliários na produção do espaço urbano. Revista: Sociedade \& Natureza. Uberlândia. 18 (35):123130.Dezembrol2006.

NUNES, Marcelo. Produção do espaço urbano e exclusão social em Marília-SP. Presidente Prudente. Dissertação (mestrado) - Universidade Estadual Paulista, Faculdade de Ciências e Tecnologia. 2007.

OLIVEIRA, Adélia Engrácia de. Amazônia: Modificações sociais e culturais decorrentes do processo de ocupação humana (século XVII ao XX). Boletim do Museu Paraense Emílio Goeldi. Belém, 4(1): 65-115. Julho\1988.

OLIVEIRA, Adélia Engrácia de. Ocupação humana. In: SALATI, E. et al. Amazonia; desenvolvimento, integração, ecologia. São Paulo, Brasiliense. pg. 144327.

OLIVEIRA, Avelino Ignácio de. Bacia do Rio Branco (Estado do amazonas). Ministério da Agricultura, Indústria e Comércio. Serviço Geológico e Mineralógico do Brasil. 1929.

OLIVEIRA, Rafael da Silva. Atlas do Estado de Roraima: Território e População Boa Vista: Editora UFRR, 2006.

OLIVEIRA, Reginaldo Gomes de. A herança dos descaminhos na formação do Estado de Roraima. São Paulo, FFLCH, USP, 2003. (Tese de doutorado).

ÓRGÃO OFICIAL DO TERRITORIAL FEDERAL DO RIO BRANCO (Diário Oficial). Boa Vista. 07\12\1944. №. 24, p. 8.

OURIQUES, Jacques. O Valle do Rio Branco : Estado do Amazonas - Edição Especial. 1906.

PAVANI, Jorge Donizette \& GUTEMBERG Moura. Panorama fotográfico urbanístico e arquitetônico de Boa Vista. 1aㅡ edição. Brasília - DF: Gráfica Coronário, 2006. 110p.ilust. 
PEREIRA, João Theófilo R. Novas Tecnologias no Planejamento Urbano de Boa Vista - (Monografia apresentada no término de curso de graduação em geografia UFRR). Boa Vista - Roraima. 2005.

PREFEITURA MUNICIPAL DE BOA VISTA. Boa Vista: Um passado glorioso, um presente de progresso, um futuro promissor. Revista comemorativa dos 100anos de Boa Vista. 1890\1990. Publicação. 1990.

PREFEITURA MUNICIPAL DE BOA VISTA. Relatório de atividade da prefeitura de Boa Vista. Período: janeiro de 1993 a março de 1996.

PREFEITURA MUNICIPAL DE BOA VISTA. Plano Diretor de Desenvolvimento Urbano de Boa Vista - PDDUIBV. Lei oㅡ 244, de 06 de Setembro de 1991.

REIS FILHO. Nestor Goulart. Notas sobre a urbanização dispersa e novas formas de tecido urbano. São Paulo: Via das Artes, 2006.

REIS FILHO. Nestor Goulart. Contribuições ao estudo da evolução urbana do Brasil (150011720). Editora da Universidade de São Paulo - SP. 1968.

REIS. Artur César Ferreira. Aspectos Econômicos da Dominação Portuguesa na Amazônia "Ocidental”. Vol. LX: Lisboa. 1961 - Pg. 106 - a 124.

REVISTA BOA VISTA 23. Coligação construindo Boa Vista. 2004.

REVISTA DIRETRIZES. Edição Histórica. Ano I. №. 2. Boa Vista-RR. JaneirolFevereiro. 1991.

REVISTA É AGORA. Nova força para Roraima. Revista de campanha de Teresa Jucá para o senado. 2006.

REVISTA SELVA. Um espelho da vida brasileira. № 13. Ano 1950.

REZENDE, Tadeu Valdir Freitas de. A conquista e a ocupação da Amazônia brasileira no período colonial: a definição de fronteiras. Universidade de São Paulo. (Tese de Doutorado). Faculdade de Filosofia, Letras e Ciências Humanas. Departamento de Historia Econômica. 2006. 
REZENDE, Vera. Planejamento urbano e ideologia: quatro planos para a cidade do Rio de Janeiro - Rio de Janeiro: Civilização Brasileira, 1982.

RICE, Alexander Hamilton. Exploração na Guiana Brasileira(1924-1925). Tradução e notas - Lacyr Schettino. Editora da Universidade de São Paulo : São Paulo, 1978.

RODRIGUES, Francilene dos Santos. Migração Transfronteiriça na Venezuela. In, Revista de Estudos Avançados. São Paulo: Instituto de Estudos Avançados da Universidade de São Paulo, 2006.

RODRIGUES, Francilene dos Santos et ali. Relatório Estadual. Pesquisa tráfico de mulheres, crianças e adolescentes para fins de exploração sexual realizada no municípios de Boa Vista e Pacaraima - Roraima/ Brasil e Santa Elena do Uairen - Venezuela. Boa Vista, 2002.

RODRIGUES, Francilene dos Santos."Garimpando" a Sociedade Roraimense: uma análise da conjuntura sócio-política. Belém, Núcleo de Altos Estudos da Amazônia, UFPA, 1996 (Dissertação de Mestrado).

SALES, Marcela da Silva. Análise da dinâmica sócioespacial do bairro União Boa VistalRoraima. Monografia de Conclusão do Curso de Licenciatura Plena em Geografia da Universidade Federal de Roraima. Departamento de Geografia. 2005.

SALLEM, Ângela Leitão. Morfologia e desenho urbano na configuração da cidade planejada: $O$ caso de Curitiba. Dissertação de Mestrado. Pontifica Universidade do Paraná. Programa de Pós-Graduação em Gestão Urbana.2006.

SAMPAIO, Francisco Xavier Ribeiro de. Relação Geográfica: Histórica do Rio Branco da América Portuguesa. 1850 In anexo COSTA, Clovis Nova da. O vale do rio Branco: suas realidades e perspectivas. Dept ${ }^{\circ}$ de imprensa oficial do Rio de Janeiro, 1949.

SANTILLI, Paulo. Fronteiras da República: História e política entre os Macuxi no vale do rio Branco. Núcleo de História Indígena e do Indigenismo - NHII . Fundação de Amparo à Pesquisa do Estado de São Paulo - FAPESP. São Paulo. 1994. 
SANTOS, Adair J. História da livre Iniciativa no desenvolvimento socioeconômico do Estado de Roraima. Boa Vista. FECOMÉRCIOIRR. 160 pg. 2004.

SANTOS, Carlos Nelson dos. A cidade como um jogo de cartas. Niterói: Universidade Federal Fluminense: EDUFF. São Paulo: Projeto Editores. 1988.

SANTOS, Milton. A Urbanização Brasileira. 5ª ed. São Paulo: Editora da Universidade de São Paulo, 2005.

SANTOS, Milton, A Natureza do Espaço: Técnica e Tempo, Razão e Emoção. São Paulo: editora da Universidade de São Paulo, 2002.

SANTOS, Milton \& SILVEIRA, Maria Laura. O Brasil: território e sociedade no início do século XXI. Rio de Janeiro. Record, 2001.

SANTOS, Milton, O retorno do território. In SANTOS, Milton et al TERRITÓRIO: Globalização e Fragmentação.São Paulo:Hucitec.1996.2ªed.

SANTOS, Milton. Por uma economia política da cidade: O caso de São Paulo. Editora Hucitec/Educ: São Paulo, 1994.

SANTOS, Milton. Por uma Geografia Nova. 3르 ed. São Paulo: Hucitec, 1990.

SANTOS, Milton. Espaço e Método. São Paulo: Nobel, 1985.

SANTOS, Nélvio Paulo Dutra. Políticas Públicas, Economia e Poder: O Estado de Roraima entre 1970 e 2000. Belém, 2004. Universidade Federal do Pará. Núcleo de Altos Estudos Amazônico - NAEA (Tese de Doutorado).

SCARLATO, Francisco Capuano. Revitalização do Centro Antigo: O Espaço da Memória de São Paulo. In Urbanização e Mundialização: Estudos sobre a metrópole. CARLOS, Ana Fani Alessandri e CARRERAS, Charles (Org.). São Paulo: Contexto, 2005.

SECRETARIA DE PLANEJAMENTO E COORDENAÇÃO. Perfil da cidade de Boa Vista. Governo do Estado de Roraima. Dezembro. 1980. 
SECRETARIA DE PLANEJAMENTO, INDÚSTRIA E COMÉRCIO: Secretaria de Agricultura e Abastecimento \Instituto de Terras e Colonização de Roraima. PROJETO: Incorporação de Áreas Remanescentes da União ao Patrimônio Imobiliário do Estado - Ocupação do Cerrado. Boa Vista - Roraima. Outubro de 2000.

SEGUNDO PLANO NACIONAL DE DESENVOLVIMENTO. Programa de Ação do Governo para o Território de Roraima. 1975-1979. Ministério do Interior. Território Federal de Roraima.Brasília. Agosto. 1975.

SILVA, Paulo Rogério de \& VERAS, Antonio Tolrino de Rezende. (Re) produzindo os territórios dos Municípios do Cantá e de Boa Vista no Estado de Roraima. Boa Vista - Roraimal2008 (Trabalho inédito a ser publicado).

SILVA, Paulo Rogério de Freitas. Dinâmica Territorial Urbana em Roraima Brasil. Programa de Pós-Graduação em Geografia Humana. Universidade de São Paulo, 2007. (Tese Doutorado).

SILVA, Paulo Rogério de Freitas. A complexidade genética do urbano na última fronteira da Amazônia - Roraima. Universidade de São Paulo - Programa de PósGraduação em Geografia Humana, 2004. (Relatório de Qualificação - Doutorado).

SILVA, Walter Jonas Ferreira da Silva. Breve ensaio sobre as ações relacionadas à questão fundiária rural-urbana no estado e município de Boa Vista. Boa Vista. 2006. Procuradoria Geral do Município - PGMU.Coordenação dos Núcleos de Assessoramento Jurídicos.Secretaria Municipal de Desenvolvimento Agrícola SMDA. BOA VISTA - RR. (Trabalho Inédito).

SILVEIRA, Isolda Maciel da \& GATTI, Marcelo. Notas sobre a ocupação de Roraima, migração e colonização. Boletim: Museu Paraense Emílio Goeldi. Série Antropológica 4(1). 1988.

SILVEIRA, Maria Laura. Um País, uma região: fim de século e modernidades na Argentina. São Paulo: FAPESP, 1999. 
SPÓSITO, Eliseu Salvério. A vida nas cidades. São Paulo: Editora Contexto, 2004, p. 89.

SPÓSITO, Maria Encarnação B. O chão em pedaços: urbanização, economia e cidades no Estado de São Paulo. Presidente Prudente: FCT/UNESP, 2004. (Tese de Livre-Docência).

TERRITÓRIO FEDERAL DE RORAIMA. Diagnóstico sócio-econômico preliminar. Associação de Crédito e Assistência Rural - RR \ACAR \Secretaria de Economia, Agricultura e Colonização. Ministério do interior. 1973.

TERRITORIO FEDERAL DE RORAIMA. Prefeitura municipal de BOa Vista. Primeira Coletânea de Códigos do Município de Boa Vista. Boa Vistal1977.

TERRITÓRIO FEDERAL DE RORAIMA. Série Monográfica - Município de Boa Vista, Secretaria de Educação e Cultura. Boa Vista. 1987.

TERRITÓRIO FEDERAL DO RIO BRANCO. Diário Oficial. Boa Vistal07-12-1944. №24. Pag.08.

TRINDADE JR. Saint-Clair Cordeiro da. Produção do espaço e uso do solo urbano em Belém. Belém: UFPA/NAEA/PLADES.1997.

VALE, Ana Lia Farias. O “ceará” em Roraima. Migração de cearenses: 1980-1999. (Texto inédito). Boa Vista-RR. 2005.

VETTER, David Michael e RZEZINSKI, Henrique Costa. Política de uso do solo: para quem. Revista de Administração Municipal, Rio de Janeiro, outubro/dezembro.pg.17, 1979.

VICENTINI, Yara. Cidade e História na Amazônia. Ed. UFPR, 2004.

VIEIRA, Jaci Guilherme. Missionários, fazendeiros e índios em Roraima: A disputa pela terra - 1777 A 1980. Boa Vista - Roraima: 2003 (Tese de Doutorado).

VILLAÇA, Flávio. Espaço Intra-urbano no Brasil. São Paulo: Stúdio Nobel: FAPESP: Lincoln Institute, 1998. 